\title{
Modernising the Law of Murder and Manslaughter: Part 1
}

\author{
Graham McBain ${ }^{1,2}$
}

${ }^{1}$ Peterhouse, Cambridge, UK

${ }^{2}$ Harvard Law School, USA

Correspondence: Graham McBain, 21 Millmead Terrace, Guildford, Surrey GU2 4AT, UK. E-mail: gsmcbain@aol.com

Received: October 17, 2015 Accepted: November 2, 2015 Online Published: November 19, 2015

doi:10.5539/jpl.v8n4p9 URL: http://dx.doi.org/10.5539/jpl.v8n4p9

\section{$\underline{\text { Index }}$}

1. Introduction

2. Source Material

3. Legal Issues not Considered

4. Meaning of Words

5. Benefit of Hindsight

6. Babylonian Code

7. Old Testament law

8. Roman law

9. Anglo-Saxon law

10. Laws of Henry I (c.1113)

11. Glanvill (c.1189)

12. Summary: Law to 1189

13. Bracton (c.1240)

14. Statute of Marlborough 1267

15. Statute of Gloucester 1278

16. Britton, Fleta \& Mirror of Justices (c.1290)

17. Statute of Trespassers in Parks 1293

18. Edward III (1327-1377)

19. Act of 1389 on Pardons

20. From 1389-1551

21. Summary: Law to 1551

22. Act of 1553 on Unlawful Assemblies

23. Staunford (1557)

24. Lambard (1581)

25. Statute of Stabbing 1603

26. Pulton (1609)

27. Dalton (1618-1746)

28. Coke (1641)

29. Summary: Law to 1641

30. Hale (c. 1670)

\section{Appendices}

$\begin{array}{ll}\text { A } & \text { Anglo-Saxon Tariff } \\ \text { C } & \text { Killing pursuant to Unlawful Act } \\ \text { E } & \text { Defences } \\ \text { G } & \text { Transferred Malice } \\ \text { I } & \text { Definitions of Murder \& Manslaughter }\end{array}$

31. Hawkins (1716-21)

32. Blackstone (1765-9)

33. Summary: Law to 1769

34. Foster (1776)

35. East (1803)

36. Russell (1819)

37. From 1819-1843

38. Royal Commissions (1843-78)

39. Stephen (1883)

40. Kenny (1902)

41. Summary: Law to 1902

42. Turner (1945)

43. Royal Commission (1953) \& Homicide Act 1957

44. Smith \& Hogan (1965)

45. Criminal Law Revision Committee (1980)

46. Williams (1983)

47. Law Commission Criminal Code (1989)

48. Carter \& Harrison (1991)

49. Justifiable Killing by 1998

50. LC Papers \& Blom-Cooper (2004-5)

51. CIJA 2008

52. Coroners and Justice Act 2009

53. Archbold 2015

54. Summary: Law to 2015

55. Homicide and Battery

56. A Statutory Definition of Murder

57. A Statutory Definition of Manslaughter

58. Abortion and Infanticide

59. Conclusion

$\begin{array}{cl}\text { B } & \text { Murder (Cases) } \\ \text { D } & \text { Provocation ('Hot Blood') } \\ \text { F } & \text { Sports \& Horseplay } \\ \text { H } & \text { Involuntary Manslaughter }\end{array}$

\section{Introduction}

At present, the English law of murder and manslaughter (together with the law on abortion and infanticide) ${ }^{1}$ is a mixture of the common law and various pieces of legislation. The two do not mesh well and this has resulted in endless problems and court cases - something which is neither conducive to justice nor to the benefit of the taxpayer. However, like many other common

\footnotetext{
${ }^{1}$ When considering a legislative form for these crimes, regard will also be had to the present position on abortion and infanticide. It is not necessary to trace their history.
} 
law crimes, part of the difficulty in putting murder and manslaughter into legislation is that its early history is little understood. Further, the chronological history of these crimes has not been laid out, in order to make it easier to see how various principles developed and - in many cases - were superceded.

The purpose of this article is to trace the history of the law of murder and manslaughter, as well as various defences to the same. This is helped by more modern translations of the Old Testament and Anglo-Saxon law than legal writers such as Bracton, Dalton, Coke, Hale, Blackstone, Hawkins and Russell had. ${ }^{2}$ As a result, the evolution of these crimes can be comprehended more easily. Having traced the history, this article proposes legislative wording for murder and manslaughter. In tracing the historical development of these crimes the following 5 primary issues may be noted, since they run like a thread through the chronology:

- Homicide - Mens Rea. Pre-eminently, the history of the crimes of murder and manslaughter has seen an evolution in the mens rea required such that, today, it is recognised - in legal terms - that a person can kill another in four ways: (a) intentionally; (b) recklessly; (c) accidentally; and (d) negligently. The Old Testament recognised only (a) and (c) and it treated (d) as part of (c). Anglo-Saxon law - which was closely based on Old Testament law - did the same. ${ }^{3}$ However, from Bracton (c. 1240) onwards, negligence, very slowly, emerged as a separate head of mens rea. Indeed, it was only really picked up by legal writers in the $19^{\text {th }}$ century. ${ }^{4}$ As for (b), this was only developed in the 20th century. There is no doubt that the failure of the common law to separate the mens rea for homicide into these four categories caused endless cases and problems down the centuries - as well as strained interpretations and inappropriate categorisation, as we shall see;

- $\quad$ Premeditation. In respect of (a), intention, the Old Testament split it into two sub-categories, (i) premeditated; and (b) unpremeditated. They had good reason to. The basic principle in the Old Testament (and Anglo-Saxon law which closely followed it) was the lex talionis: ${ }^{5}$ a life for a life. God himself had declared it. ${ }^{6}$ However, to apply this divine statement in all its purity (rigour) in the Old Testament and Anglo-Saxon eras would likely have robbed society of much of its manpower ${ }^{7}$ since those times were violent and men were endlessly fighting and brawling - the Anglo-Saxons especially so. ${ }^{8}$ Therefore, at least from the Book of Exodus onwards, the consequences of intentional killing were bi-furcated.

- If the killing was premeditated - that is, planned - no mercy was to be shown to the killer. There was no right to sanctuary ${ }^{9}$ and the payment of compensation (blood money) was not possible. The death penalty applied and it could be imposed by the elders (judges) or by the lawful avenger by way of private retaliation (also called private revenge, the vendetta or the blood feud); 10

- If the killing was unpremeditated - such as in a brawl ${ }^{11}$ - mercy could be shown. There was a right to sanctuary and compensation could be substituted for the death penalty (providing the victim's kin accepted this);

- The exception in the case of brawling (quarrelling) contained within it elements of mitigation, viz: provocation and self-defence. Likely, these were taken into account (in practice) in Old Testament and Anglo-Saxon times - even though they did not comprise (it seems) separate legal principles. However, in

\footnotetext{
${ }^{2}$ In the history of murder and manslaughter there is no doubt as to the great influence of the writings of: Bracton (c. 1240), Dalton (1618-1746), Coke (the third volume of his Institutes was published in 1641), Hale (his History of the Pleas of the Crown was in manuscript form until his death in 1676. The manuscript was only published in 1736), Blackstone (1765-9), Hawkins (1716-1824), Russell (1819-1964) and Kenny (1902-66).

${ }^{3}$ To the modern mind, the failure to separate accidental and negligent killing is strange. However, to the Old Testament and Anglo-Saxon mind, both were 'Acts of God'. Roman law did not have this pre-occupation and more clearly distinguished negligent, from accidental, killing.

${ }^{4}$ Russell in the first edition of his work in 1819 , see 36. Hale had referred to 'debitam diligentiam'. However, his illustrations were mainly based on Roman law (and Bracton) and he never considered the concept of criminal negligence in any detail.

${ }^{5}$ As JF Davis, Lex Talionis in Early Judaism and the Exhortation of Jesus in Matthew 5.38-42 (T \& T Clark Int. 2005), p 1 noted, the term 'lex talionis' did not come from the Old Testament but from the Roman Twelve Tables (see 8), table 8 'When anyone breaks a member of another, and is unwilling to come to make a settlement [composition] with him, he shall be punished by the law of retaliation.' ('Si membrum rupsit, ni cum eo pacit, talio esto'). (underling supplied)

${ }^{6}$ Compact NIV Study Bible (Hodder \& Stoughton)('NIV'), Book of Genesis, ch $9 \mathrm{v} 6$ 'Whoever sheds the blood of man, by man shall his blood be shed.' This principle (leaving aside the possibility of divine ordinance) was also the prevailing principle under Babylonian law. That is, like for like; the punishment must reflect the crime.

${ }^{7}$ It was the same for lesser physical injuries, such as 'an eye for an eye, a tooth for a tooth' etc. In practice, Old Testament - and Anglo-Saxon - law established a means of satisfying both God and man. The strict law was held to apply unless the injured party was prepared to accept compensation. Further, in the case of homicide, to prevent the population from being a collection of cripples (as well as to avoid endless retaliation) one suspects that, in practice, judges (and elders) placed heavy pressure on the victim's kin to accept compensation, as opposed to killing in revenge.

${ }^{8}$ Doubtless, Anglo-Saxons were like their Germanic stock. Tacitus on Britain and Germany (Penguin, 1954), pp 112-3: 'The Germans have no taste for peace; renown is easier won among perils, and you cannot maintain a large body of companions except by violence and war... They love indolence but they hate peace.'

${ }^{9}$ Even if the pre-meditated killer sought sanctuary by an altar of God (in a temple) or in one of the 6 cities of refuge (in Old Testament times) he could be dragged out from the same. This may have also applied in early Anglo-Saxon times (in respect of churches).

${ }^{10}$ Enforcement of the lex talionis in the case of homicide comprised the right of the nearest male kin to kill the killer in revenge. This was when criminal justice - in undeveloped or scattered societies - was administered by the kin (or tribe) as opposed to some more central organ of government. The problem of the blood feud was that it was very difficult to stop, once initiated.

${ }^{11}$ This was the common example. However, it also exposed the legal problems which (inevitably) resulted since a person could secretly 'engineer' a brawl in order to kill his opponent. This was pre-meditation, in reality. Or, in the course of a brawl, a person could form a secret intention to kill and then wait for his opportunity. This, also, was pre-meditation, in reality. Further, what period of time should be allowed between the brawl and the killing? Suppose tempers cooled a little and, then, the brawl started up again. Was it now pre-meditated?
} 
English law they (slowly) started to become separate principles - effectively ending the need for bi-furcation, since the issue then became one of intention.

The need for premeditation as a pre-requisite for murder - although illogical ${ }^{12}$ - flowed into early medieval law (as malice aforethought) ${ }^{13}$ and it was to be-devil the offence of murder for centuries, long after the need to bi-furcate intentional killing was necessary (that is, after 1828 at least). ${ }^{14}$ Today, there is no bi-furcation. And, there is no need for it, for the issue of fighting (quarrelling) has now been replaced by elements that were a part of it. Thus, if a person intentionally kills in a brawl, it is murder unless a defence applies in some form or sufficient provocation can be evidenced, reducing it to manslaughter;

- Defences. Old Testament - and later Anglo-Saxon - law, did not refer to 'defences' as such. Instead, they distinguished between: (a) justifiable killing, where no crime was committed ${ }^{15}$ and (b) excusable killing, such as when a person killed in self-defence or to defend others. Today, under English law, (a) has gone with no murder being lawful except the killing of an enemy alien in war time. And (b) has been categorised into discrete 'defences' referred to in legislation. A summary of all the grounds for justifiable killing available at one time or another - as well as when they became obsolete - is provided in $\mathbf{4 9}$;

- Legal Fiction: Implied (Constructive) Malice. English law, generally, has not been helped by legal fictions (which are - by their very nature - false in practice). This is especially so in the case of the criminal law. From the $16^{\text {th }}$ century - even though there was no premeditated malice (because no malice was shown to the victim) - malice was implied in the cases of:

- unprovoked (including random) killing;

- killing a police officer in the execution of his duty;

- killing arising from an unlawful act;

- killing by a thief (robber);

- $\quad$ killing by neglect/cruelty (to the extent not express malice);

- transferred malice.

After sustained criticism, some of these implied malices were abolished by the Homicide Act 1957, s 1 and, to the extent not, by the obsolescence of the concept of premeditated malice. Today, murder being based on 'intention' no malice has to be shown to the victim (albeit, 'transferred malice' is preserved in that the intent to kill and the act do not have to be directed at the same person);

- Legal Fiction: Unlawful. Bracton (c.1240), a cleric - following ecclesiastical law - distinguished between accidental, and negligent, killing (without 'due care'), although no meaningful separation was made until a number of centuries later. He also posited (unfortunately) another criterion - whether the act leading to the killing was lawful or not (latin, licet). Bracton did not spell out the precise consequences of this. However, it was asserted by Coke (in a work published in 1641) as well as by others before him that - if a person killed accidentally when in the course of an unlawful act - this rendered it murder. Such a doctrine - one which Stephen termed 'cruel and indeed monstrous' was sought to be mitigated by Foster (in a work published in 1762) by limiting it to an unlawful act that was a felony. Then, Kenny (in 1902) noted a 'modern tendency' to further limit it to felonies likely to cause death. As it was, this fiction was flawed from the outset since it failed to separate: (a) the unlawful act; from (b) the killing, which had its own distinct mens rea. This legal fiction as to unlawfulness in respect of murder was abolished by the Homicide Act 1957, s 1, save as to killing pursuant to an intent to cause grievous bodily harm. In the case of manslaughter it continues, although it is unnecessary, as will be seen.

There is no doubt about it. The history of murder and manslaughter is a 'long and winding road.' However, it is astonishing how much of it comprises the above five issues (at least, $80 \%$ of all legal writings and caselaw) and that the law in this area is, actually, simpler than it seems. All the more reason, then, for placing murder and manslaughter into legislation, using modern terminology. Even more so, the history of the law on murder and manslaughter is clear evidence that: (a) unduly restrictive categorisation; and (b) the employment of legal fictions, can severely impede the development of the law and - indeed - justice. This article now considers the history of these crimes in detail. However, for those who like to 'fast forward', a summary of all the law up to 2015 is provided in $\mathbf{5 4}$.

In conclusion, this article asserts that murder and manslaughter should become statutory offences.

\footnotetext{
${ }^{12}$ It was 'illogical' since the lex talionis - being one of strict equivalent redress - should have recognized no exceptions in the case of any intentional killing. Further, the random killing of a person (where there was no premeditation) was (and is) as (if not more) heinous than premeditated killing (it resulted in the need to 'imply' malice in later English law).

13 See FW Maitland, The Early History of Malice Aforethought in HAL Fisher (ed), The Collected Papers of Frederic William Maitland (1911), vol 1, $\mathrm{p}$ 304 et seq.

14 The central distinction in Old Testament (and Anglo-Saxon) law between premeditated and unpremeditated killing was that compensation was payable for the latter but not the former. However, by the time of Bracton (c. 1240) compensation (and the tariff system of compensatory payments) had been superceded. Thereafter, both types of killing merited the death penalty under English law and the distinction between murder (pre-meditated) and other intentional killing, then became a matter of issues such as: (a) the right to sanctuary (abolished for murder in 1540 and, generally, in 1628 ); (b) the right to claim benefit of clergy (abolished for murder in 1531 and, generally, in 1827); (c) the availability of a pardon; (d) forfeiture of land, goods and chattels (abolished 1870 (abolished in 1828 in the case of accidental killing and killing in self defence).

${ }^{15}$ For example, where the death penalty was lawfully imposed by a court.
} 


\section{Source Material}

As might be expected, murder and manslaughter have been referred to extensively in legal texts, ${ }^{16}$ cases and legislation. However, in respect of English legal texts, a few have always dominated the field ${ }^{17}$ and secondary texts tend to simply cross-refer to them (or repeat their contents). With regard to this article, the following primary texts are considered:

- Anglo-Saxon Law. Reference is made to texts by Attenborough, Robertson and Thorpe ${ }^{18}$ which contain translations of laws (dooms) from king Aethelbert (c. 518-616) until the Norman Conquest of 1066. Reference is also made to O'Brien, which contains an alleged version of the laws of Edward the Confessor (1042-66) which was likely written in the 1140 ' $\mathrm{s}{ }^{19}$

- Medieval Texts. Reference is made to the Laws of Henry I (c. 1113) ${ }^{20}$ as well as to the first text on English law, by Glanvill (c. 1189). ${ }^{21}$ Also, to Bracton (c. 1240), ${ }^{22}$ Britton, (c. 1290), ${ }^{23}$ Fleta (c. 1290) ${ }^{24}$ and the Mirror of Justices (c. 1290); $;^{25}$

- Yearbooks, Selden Society Reports \& Book of Assizes. Reference is made to the Yearbooks (1268-1535), ${ }^{26}$ the Selden Society reports ${ }^{27}$ and the Book of Assizes (Liber Assisarum)(being criminal cases in time of Edward III, 1327-77); ${ }^{28}$

- $\quad$ Abridgments. Reference is made to the abridgments of Statham (c.1490), ${ }^{29}$ Fitzherbert (c.1516) ${ }^{30}$ and Brooke $(1586){ }^{31}$ as well as to the later abridgments of Hughes (1660-3), ${ }^{32}$ Rolle (1668), ${ }^{33}$ Sheppard (1675), ${ }^{34}$ Nelson $(1725-6),{ }^{35}$ Viner $\left(1^{\text {st }}\right.$ ed, 1741-57), ${ }^{36}$ Bacon $\left(5^{\text {th }}\right.$ ed, 1798) ${ }^{37}$ and Comyns (last ed, 1822); ${ }^{38}$

- $\quad \mathbf{1 6}^{\text {th }} \& 17^{\text {th }}$ Century Texts. Reference is made to texts on justices of the peace by Fitzherbert (1538) ${ }^{39}$ and Lambard (1581). ${ }^{40}$ Also, to the first text on criminal law by Staunford (1577) ${ }^{41}$ and well as to texts by Pulton $(1609-23),{ }^{42}$ Dalton (1618-1746), ${ }^{43}$ Coke (1628-41) ${ }^{44}$ and Hale (published in 1736); ${ }^{45}$

\footnotetext{
${ }^{16}$ Although the criminal law seems inexhaustible, in the period 1189 (from Glanvill) until 1965, there were only about 80 texts on criminal law (albeit many editions).

${ }^{17}$ See $\mathrm{n} 2$.

${ }^{18}$ FL Attenborough, The Laws of the Earliest English Kings (NY, 1963); AJ Robertson, The Laws of the Kings of England from Edmund to Henry I (Cambridge UP, 1925)(the latter covers legislation from AD 942 up to the reign of Henry I (1100-35)) and B Thorpe (ed), Ancient Laws and Institutes of England (1840). For another translation of the earliest law, that of Aetherbert (597-616 AD), see P Wormold, The First Code of English Law (Canterbury Commemoration Society, 2005). See also J Hudson, The Oxford History of the Laws of England (OUP, 2012), vol 2.

${ }^{19}$ BR O'Brien, God's Peace and King's Peace. The Laws of Edward the Confessor (Univ. of Pennsylvania Press, 1999). See also BR O'Brien, From Mordor to Murdrum: The Preconquest Origin and Norman revival of the Murder Fine (1996) 71 Speculum 321-57.

${ }^{20}$ LJ Downer, Leges Henrici Primi (Oxford, 1972).

${ }^{21}$ Glanvill, The Treatise on the Laws and Customs of the Realm of England (c. 1189)(Nelson, 1965).

${ }^{22} \mathrm{H}$ Bracton (trans Thorne), On the Law and Customs of England c. 1240 (Cambridge UP, 1968-76). Bracton is now online, see bracton.law.harvard.edu. See also JM Kaye, Placita Corone (c. 1274-5, Selden Society, 1966).

${ }^{23}$ FM Nichols (ed), Britton (John Byrne \& Co, 1901).

${ }^{24}$ Fleta, see Selden Society ('SS'), vols 72, $89 \& 99$.

${ }^{25}$ Mirror of Justices, SS, vol 7.

${ }^{26}$ The best edition is that of Maynard (Vulgate, 1678), reprinted by LBE. David Seipp (a professor at Boston university) has put translations of most of the 22,000 Yearbook cases online in the form of an Index. See www.bu.edu/law/faculty/scholarship/yearbooks.

${ }^{27}$ See selden.society.com. Also www.wshein.com/ which has put SS vols 1-99 online.

${ }^{28}$ See www.lawbookexchange.com/. The Liber was first published in 1516 (J Rastell).

${ }^{29}$ N Statham, Abridgment of the Law (Pynson, c.1490). See translation of MC Klingelsmith (Boston Book Co., 1915).

${ }^{30}$ A Fitzherbert, La Graunde Abridgment. The $3^{\text {rd }}$ ed (1577) is generally preferred and it is cited in this article. The $3^{\text {rd }}$ edition has been reprinted by the Law Book Exchange.

${ }^{31}$ R Brooke, La Graunde Abridgment (Tottell, 1586).

${ }^{32}$ W Hughes, Grand Abridgment of the Law (Henry Twyford et al, 1660-3). This has been reprinted by the Law Book Exchange.

${ }^{33}$ H Rolle, Abridgment des plusieurs Cases et Resolutions del Common Ley (A Crooke et al, 1668).

${ }^{34}$ W Sheppard, Grand Abridgment of the Common and Statute Law of England (sold by George Sawbridge et al, 1675).

${ }^{35}$ W Nelson, Abridgment of the Common Law (E \& R Gosling, 1725-6). This has been reprinted.

${ }^{36}$ E Viner, A General Abridgment of the Law and Equity (GCJ \& J Robinson, $1^{\text {st }}$ ed, 1741-57, $2^{\text {nd }}$ ed 1791). This has been reprinted by the Law Book Exchange (there is also a $\mathrm{CD}$ with wordsearch).

${ }^{37}$ M Bacon, New Abridgment of the Law ( $1^{\text {st }}$ ed, $1736 ; 5^{\text {th }}$ ed (H Gwillim (ed), 1798; last ed ( $7^{\text {th }}$ ed), 1832).

${ }^{38}$ J Comyns, Digest of the Laws of England ( ${ }^{\text {st }}$ ed, 1762-7, last ed, 1822). See also J Lilly, Practical Register $\left(1^{\text {st }}\right.$ ed, 1719; $2^{\text {nd }}$ ed, with supplement, 1745).

${ }^{39}$ A Fitzherbert, The New Boke of Justices of the Peas (London, 1538, rep Professional Books, 1972). This was a translation of L'Office et Auctoryte des Justyces de Peas, printed earlier that year. Fitzherbert's text was later edited by Richard Crompton, see R Crompton, L'Office et Auchtoritie de Justices de Peace (1584, rep Professional Books). In this article I cite the 1593 edition.

${ }^{40}$ W Lambard, Eirenarcha (1581) This has been reprinted by the Law Book Exchange. The last edition was in 1619.

${ }^{41}$ W Staunford, Les Plees del Coron (Richard Tottell, $1^{\text {st }}$ ed, 1557, last ed, 1607). This has been reprinted by the Law Book Exchange.

${ }^{42}$ F Pulton, De Pace Regis et Regni (printed for the Companie of Stationers, 1609). The last edition ( $4^{\text {th }}$ ed) was in 1623 . The first edition has been reprinted by the Law Book Exchange.
} 
- $\quad \mathbf{1 8}^{\text {th }}$ Century Texts. Reference is made to texts by Hawkins (1716-1824), ${ }^{46}$ Burn (1755 -1869), ${ }^{47}$ Blackstone $(1765-9){ }^{48}$ and Eden $(1771) ;^{49}$

- $\quad \mathbf{1 9}^{\text {th }}$ Century Texts. Reference is made to texts by East (1803), ${ }^{50}$ Russell (1819-1964), ${ }^{51}$ Archbold (1822 - date) ${ }^{52}$ Gabbett (1843), ${ }^{53}$ Harris (1881-1973) ${ }^{54}$ and Stephen (1883) ${ }^{55}$ - including the latter's History of the Criminal Law of England (1883);

- $\quad \mathbf{2 0}^{\text {th }}$ Century Texts. Reference is made to texts by Kenny (1902-66), ${ }^{57}$ Turner (1945), ${ }^{58}$ Cross and Jones (1949), ${ }^{59}$ Smith and Hogan (1965), ${ }^{60}$ Williams (1961), ${ }^{61}$ Fitzgerald (1962), ${ }^{62}$ Carter and Harrison (1991), ${ }^{63}$ Stone (1999); ${ }^{64}$

- $\quad \mathbf{2 1}^{\text {th }}$ Century Texts. Reference is made to Holdsworth, ${ }^{65}$ Halsbury, ${ }^{66}$ Blackstone's Criminal Practice (2015) ${ }^{67}$ Archbold's Magistrates Courts Criminal Procedure (2015) ${ }^{68}$ and to a plethora of modern texts on criminal law; ${ }^{69}$

- Law Reports. Reference is made to the English Reports (1220-1873), ${ }^{70}$ Cox's Criminal Cases (1843-1948), ${ }^{71}$ Law Reports (1865 - date), Criminal Appeal Reports (1908 - date), Weekly Law Reports (1953-date), All England Law Reports (1936 - date), ${ }^{72}$ Times Law Reports (1884 -1952) ${ }^{73}$ and the Law Times Reports (1843-1965); ${ }^{74}$

${ }^{43}$ M Dalton, The Countrey Justice (Societie of Stationers, $1^{\text {st }}$ ed, 1618; $2^{\text {nd }}$ ed, 1619; last ed, 1746). The first edition has been reprinted by the Law Book Exchange.

${ }^{44}$ E Coke, Institutes of the Laws of England (W Clarke \& Sons, London, last ed, 1824, which is cited).

${ }^{45} \mathrm{M}$ Hale, The History of the Pleas of the Crown (printed for E \& R Nutt \& R Gosling, 1736). See also M Hale, Pleas of the Crown (London, 1685) ('Hale PC'). For commentary on Hale, see also A Amos, Ruins of Time (1856).

${ }^{46}$ W Hawkins, A Treatise on Pleas of the Crown (E \& R Nutt \& R Gosling, Savoy ( $1^{\text {st }}$ ed 1716-21; last ed ( $8^{\text {th }}$ ed), 1824).

${ }^{47}$ R Burn, The Justice of the Peace and Parish Officer ( $\left(1^{\text {st }}\right.$ ed, 1755 , last ed $\left.\left(30^{\text {th }} \mathrm{ed}\right), 1869\right)$. See also a useful work, R Beville, $A$ Treatise on the Law of Homicide and of Larceny at Common Law (1799).

${ }^{48}$ W Blackstone, Commentaries on the Laws of England (Oxford, Clarendon Press, $1^{\text {st }}$ ed, 1765-9, University of Chicago Press rep 1979). The final edition of Blackstone was effectively that of HJ Stephen, New Commentaries on the Laws of England (4 vols, 1841-5), although much of the input was of the latter. The last edition of Stephen was the $21^{\text {st }}$ ed (1950).

${ }^{49} \mathrm{~W}$ Eden, Principles of Penal Law ( $2^{\text {nd }}$ ed, 1771).

${ }^{50}$ EH East, $A$ Treatise of the Pleas of the Crown (only ed, 1803).

${ }^{51}$ WO Russell, $A$ Treatise on Crimes and Misdemeanors ( $1^{\text {st }}$ ed, 1819). The last edition of Russell (the $12^{\text {th }}$ ed) was in 1964, edited by JWC Turner.

52 W Archbold, Criminal Pleading, Evidence and Practice (Sweet \& Maxwell, 2015). See also JF Archbold, A Summary of the law relative to Pleading and Evidence in Criminal Cases (1822, being the $1^{\text {st }}$ ed).

$53 \mathrm{~J}$ Gabbett, Treatise on the Criminal Law (Dublin, 1843).

${ }^{54}$ SF Harris, Principles of the Criminal Law (Stevens \& Haynes, 1881). The last edition was in 1973.

${ }^{55}$ JF Stephen, A Digest of the Criminal Law (Macmillan \& Co, $3^{\text {rd }}$ ed, 1883). See also JF Stephen, A General View of the Criminal Law (Macmillan, 1863).

${ }^{56}$ JF Stephen, A History of the Criminal Law of England (Macmillan \& Co, 1883).

${ }^{57}$ CS Kenny, Outlines of Criminal Law (Cambridge UP, $1^{\text {st }}$ ed, 1902). See also JWC Turner, Kenny's Outlines of Criminal Law (19 ${ }^{\text {th }}$ ed, 1966, last edition).

${ }^{58}$ Chapter by JWC Turner, The Mental Element in Crimes at Common Law in PH Winfield, The Modern Approach to Criminal Law (1945),

${ }^{59} \mathrm{R}$ Cross \& PA Jones, An Introduction to Criminal Law (2 ${ }^{\text {nd }}$ ed, 1949). The $1^{\text {st }}$ ed was in 1948.

${ }^{60}$ JC Smith \& B Hogan, Criminal Law (1st ed, 1965).

${ }^{61}$ G Williams, The General Part (1961).

${ }^{62}$ FJ Fitzgerald, Criminal Law and Punishment (1962).

${ }^{63}$ P Carter \& R Harrison, Offences of Violence (1991).

${ }^{64} \mathrm{R}$ Stone, Offences against the Person (1999).

${ }^{65}$ W Holdsworth, A History of English Law (Sweet \& Maxwell, 2009 rep).

${ }^{66}$ Halsbury, Laws of England $\left(5^{\text {th }}\right.$ ed, with updates).

${ }^{67}$ Blackstone's Criminal Practice 2015 (eds. A Hooper \& D Ormerod)('Blackstone CP').

${ }^{68}$ Archbold, Magistrates Courts Criminal Procedure (2015) ('Archbold Procedure').

${ }^{69}$ See, for example: (a) C McAlhone \& R Huxley-Binns, Criminal Law. The Fundamentals (3rd ed, 2013); (b) MJ Allen, Textbook on Criminal Law $\left(12^{\text {th }}\right.$ ed, 2013); (c) A Ashworth \& J Horder, Principles of Criminal Law ( $7^{\text {th }}$ ed, 2013); (d) R Card et al, Criminal Law (20 ${ }^{\text {th }}$ ed, 2012); (e) CMV Clarkson \& HM Keating, Criminal Law, Text and Materials ( ${ }^{\text {th }}$ ed, 2010); (f) C Elliott \& F Quinn, Criminal Law ( ${ }^{\text {th }}$ ed, 2010); (g) R Heaton, Criminal Law (2 ${ }^{\text {nd }}$ ed, 2006); (h) J Herring, Criminal Law $\left(8^{\text {th }}\right.$ ed, 2013); (i) M Jefferson, Criminal Law ( $9^{\text {th }}$ ed, 2009); (j) Lacey, Wells \& Quick, Reconstructing Criminal Law. Text and Materials ( $4^{\text {th }}$ ed, 2010); (k) J Loveless, Complete Criminal Law. Text. Cases and Materials ( $3^{\text {rd }}$ ed, 2012); (1) N Padfield, Criminal Law $\left(7^{\text {th }}\right.$ ed, 2010); (m) A Reed \& B Fitzpatrick, Criminal Law ( $4^{\text {th }}$ ed, 2009); (n) AP Simester, Simester \& Sullivan's Criminal Law: Theory and Doctrine $\left(5^{\text {th }}\right.$ ed, 2013); (o) D Ormerod, Smith \& Hogan's Criminal Law (13 ${ }^{\text {th }}$ ed, 2011); (p) DJ Baker, Glanville Williams Textbook of Criminal Law $\left(1^{\text {st }}\right.$ ed, 1978, $3^{\text {rd }}$ ed, 2012); (q) MJ Allen \& S Cooper, Elliott \& Woods' Cases and Materials on Criminal Law (1 $\left.1^{\text {th }} \mathrm{ed}, 2013\right) ;(\mathrm{r})$ M Molan, Cases and Materials on Criminal Law ( $4^{\text {th }}$ ed, 2008); (s) J Martin \& T Storey, Unlocking Criminal Law $\left(3^{\text {rd }}\right.$ ed, 2010); (t) P Hungerford-Welch \& A Taylor, Sourcebook on Criminal Law (1997); (u) M Molan et al, Bloy \& Parry's Principles of Criminal Law (4 ${ }^{\text {th }}$ ed, 2000); (v) W Wilson, Criminal Law (4 $4^{\text {th }}$ ed, 2011); (w) J Cooke, Law of Tort (11th ed, 2003). See also L Blom-Cooper \& T Morris ('Blom-Cooper') With Malice Aforethought. A Study of the Crime and Punishment for Homicide. (2004)

${ }^{70}$ They comprise 178 volumes. Prior to the English Reports are the Selden Society reports, see n 27.

${ }^{71}$ EW Cox, Reports of Cases in Criminal Law (31 vols, 1843-1948), also called Cox's Criminal Cases.

72 There is also the All England Law Reports Reprint series from 1558-1935 (36 vols).

${ }^{73}$ This comprised 71 volumes. After 1952, it continued as reports in the Times. 
- Case Reports. Reference is made to Kelyng, Cases in Pleas of the Crown (1708), ${ }^{75}$ Leach, Cases in Crown Law $(1815),{ }^{76}$ Foster, Crown Cases (1809) ${ }^{77}$ and Select Cases from the Twelve Judges' Notebooks ${ }^{78}$

- Law Journals. Reference is made, inter alia, to the Law Magazine (1828-1915) ${ }^{79}$ Criminal Law Review (1954 date), Journal of Criminal Law (1937 - date), Law Quarterly Review (1885 - date) and the Modern Law Review (1937 - date).

\section{Legal Issues Not Considered}

As might be expected - over the course of time - various legal principles in respect of homicide have been abolished. Certain of these, therefore, will not be considered in this article. These comprise the following:

- Year and a Day Rule. To establish a limit on causality, it was a long established principle that an act was not presumed to have caused a person's death if more than a year and a day had elapsed before the death. This rule was abolished by the Law Reform Act 1996;

- Deodand. Since homicide was taken to be the killing of one person by another, the killing of a person by an animal (or object) was not treated as homicide. However, the animal (or object) could be forfeited to the Crown (it was called a deodand). Deodand was abolished in $1846 ;^{80}$

- $\quad$ Suicide. This crime was treated as an aspect of murder (being self murder) from early on. The Suicide Act 1961 made suicide no longer a crime.

\section{Meaning of Words}

In considering the history of murder and manslaughter, there are problems of language and of translating a legal concept from one language into another. Further, meanings often evolved over time.

- In this review, consideration is given to the following laws (and languages): Babylonian law (akkadian), Old Testament law (hebrew), Roman law (latin), Anglo-Saxon law (anglo-saxon), early medieval law (law French) and later English law;

- Doubtless, under these laws - in their time - legal concepts relating to homicide were readily comprehended by the relevant judges (elders). Today, however, given the great antiquity of these laws, the position on homicide and how the laws were interpreted - as well as applied in practice - is open to some conjecture. This should be born in mind;

- That said, in less sophisticated societies, there is less jurisprudence (and academic speculation). Thus, judges (as well as jurors) in early times - including up to the time of, at least, Bracton (c. 1240) - would have taken a practical approach. Indeed, it seems clear from Babylonian times up to that of Bracton, the primary issues were very simple. The judge (jury) would have asked themselves:

- Category of Killing? Was the killing accidental (this included negligent killing as well as acting in self-defence). Or was it justifiable (such as lawful execution) ? Or was it intentional ? If accidental, compensation was paid by the killer, instead of the death penalty. If justifiable, no crime was committed;

- Premeditated Killing? If the killing was intentional, a further question was asked. Was it premeditated or not? If the former, the death penalty applied; compensation was not payable. If otherwise intentional (such as killing during a brawl) compensation was payable.

- These basic issues were translated from one language to another. In particular, Old Testament language was adopted into Anglo-Saxon law to a considerable extent by clerics. Thus, words in Anglo-Saxon law - as well as later Law French - were, often, literal attempts to translate the latin and hebrew of the Old Testament. ${ }^{81}$

As to various legal terms employed in this article - and their evolution - the following may be noted:

- Homicide/Manslaughter. The English word 'homicide' ${ }^{82}$ derives from the latin - from homo and caedes, the killing of a man. ${ }^{83}$ In earlier times, homicide was synonymous with the english word 'manslaughter' 84 and both

\footnotetext{
74 This comprised 236 volumes. It then became part of the New Law Journal (a Butterworths publication) in 1965.

75 J Kelyng (Sir), Reports of divers cases in Pleas of the Crown $\left(1^{\text {st }} \mathrm{ed}, 1708 ; 3^{\text {rd }}\right.$ ed (last ed), 1873).

76 T Leach, Cases in Crown Law [1730-1815] ( $1^{\text {st }}$ ed 1789; last ed $\left(4^{\text {th }}\right.$ ed) 1815$)$.

${ }^{77}$ M Foster, Crown Cases ( $1^{\text {st }}$ ed; 1762, $3^{\text {rd }}$ ed (last ed), 1809).

${ }^{78}$ DR Bentley (ed), Select Cases from the Twelve Judges' Notebooks (London, 1997).

79 This comprised 131 volumes. Also called the Quarterly Review of Jurisprudence (31 vols ,1828-44), new series (24 vols, 1845-56), it became the Law Magazine and Review (32 vols, 1856-71), new series (4 vols, 1872-5) and 4th and 5th series (1875-1915). The first law journals in England only commenced in the 1760's. However, for the purposes of this article, it may be noted that - prior to the Law Quarterly Review which commenced publication from 1885 - commentary on journals on criminal matters was of little merit or has now been superceded.

${ }^{80}$ DM Walker, The Oxford Companion to Law (Oxford, 1980), (deodand) '(Deo dandum, to be given to God). A personal chattel which had been the immediate cause of the death of a living being and which at common law was forfeit to the Crown to be applied to pious uses. The principle of attributing responsibility to animals or things is very ancient, and in the Middle Ages, sometimes led to judicial trials of animals or things for manslaughter...' See also $9 \& 10$ Vict c 62 (1846). Also, Kenny, n 57, p 107.

${ }^{81}$ In Anglo-Saxon, and early medieval, England there would have been few clerics who could have read the original hebrew and most legal writers considered the latin version of the Bible (deriving from St Jerome's translation from the hebrew), the Biblia Sacra Vulgata (Deutsche Bibelgesellschaft, 1994)(the 'Vulgate').

${ }^{82}$ Oxford English Dictionary ('OED')(homicide) 'F[rench] homicide (12 $\left.{ }^{\text {th }} \mathrm{c}\right) \mathrm{L}$ [atin] homocida shortened version of homo, hominis man plus caedere, cidere to kill. One who kills a human being, a manslayer; in earlier use often = murderer. Also, 'The action, by a human

being, of killing a human being.' Blom-Cooper, n 69, p 15 'The term 'homicide' derives from the latin homicida; in turn a conjunction of homo (a man or human being) and caedo (to cut, cut down, strike or beat).'
} 
were used in contra-distinction to murder (premeditated killing) to cover any other type of killing of one man by another - such as accidental, negligent or reckless killing, as well as killing in self-defence or subsequent to provocation.

Things have changed since - today - the word 'homicide' tends to be used in neutral fashion to signify any killing by one person of another (including murder). And, 'manslaughter' tends to be used to distinguish killing that is not murder.

- $\quad$ Murder. The English word 'murder' ${ }^{85}$ is often said to have derive from the (barbarous) latin word 'murdrum' 86 which was the term used for a fine that was payable on the killing of a Dane (and, later, a Frenchman or any foreigner) where the killer was not produced ${ }^{87}$ (this fine was abolished in 1340). More likely, however, ${ }^{88}$ the word 'murder' is the barbarous latin translation of the Anglo-Saxon word 'morth' ${ }^{89}$ which, in a legal sense, referred to the premeditated killing of a person. ${ }^{90}$ And the use of the word 'morth' was (likely) an attempt by the clerics who drafted Anglo-Saxon laws to translate the hebrew concept for premeditated killing - a killing that was plotted (with guile), one also reflecting an evil disposition (malice). ${ }^{91}$ It is logical to assume this since Anglo-Saxon law is full of biblical references.

In short, the English word murder likely derived from the barbarous latin 'murdrum' - a translation of the Anglo-Saxon word 'morth' - which, itself, sought to reflect a killing committed with 'insidias' (in latin) or 'bearemah' (hebrew). All these words connoted the presence of premeditation, reflecting 'guile' (plotting) as well as the act being done in secret, as opposed to in the open in the case of a brawl. Things have changed since, today, the word 'murder' covers only intentional, or reckless, killing.

- Chance Medley. This English word ${ }^{92}$ probably derived from 'chance melee' (or chaude melee). ${ }^{93}$ The term referred to killings which arose out of a fight or brawl (a melle, melee) as a result of a combination of 'intention/accident' 94 Thus, this term was used where the killing was intentional but not treated as premeditated

${ }^{83}$ Bracton (c. 1240), n 22, vol 2, p 340 'Homicide is the slaying of man by man [Et est homicidium hominis occisio ab homine facta]', see 13. G Crabb, A History of English Law (1829), p 292 'Homicide, homicidium, from homo and caedes, that is, the slaughter of a man, was the general name for killing a man...'

${ }^{84}$ OED, n 82 (manslaughter) 'The killing of a human being by a human being; homicide.' Also, 'In etymological meaning there is no difference between manslaughter and homicide.' JH Baker, An Introduction to English Legal History (4 ${ }^{\text {th }}$ ed, 2002), p 529, n 54 “'Manslaughter' is simply the English word for homicidium; the technical sense is a result of transferring it from the genus to the residual category.' He also noted the term 'manslaughter' was in use by 1480 . Cf. Holdsworth, $\mathrm{n} 65$, vol 3, p 314 (manslaughter became a legal term in the $16^{\text {th }}$ century). See also 1 Edw VI c 15 (1547), s 6 which refers to 'all manner of manslaughters'

${ }^{85}$ Ibid (murder) 'To kill (a human being) unlawfully with malice aforethought; in early use often with the additional notion of concealment of the offence, to kill wickedly, inhumanly, or barbarously.'

86 There were variants to the word such as 'mordrum' and 'murthrum'. See generally, JH Baxter \& C Johnson, Medieval Latin Word-List (1955).

${ }^{87}$ Maitland, n 13, p 305 'The word murder...was a very old word, but had early gotten a very strange and technical meaning. Of this it was robbed by the statute of 1340 , which abolished the presentment of englishry.'

${ }^{88}$ Stephen, n 55, vol 3, p 25 'The word 'murdrum' ...the latinized form of 'morth'. O'Brien, n 19 (article), p 329 'Murdrum...is merely a latinized germanic word present in analogous forms, though with differing semantic fields, in all three relevant vernaculars: old english, old danish and old french. See also Ibid, p 351 \& 356 (means unatonable killing). Also, p 353, n 152 and G Garnett, Franci et Angli: The Legal Distinctions between Peoples after the Conquest (1985) Anglo-Norman Studies, vol 8, p 125, 'murdrum or morth means no more than secret homicide'. F Pollock \& FW Maitland, The History of English Law (Cambridge UP, 1968) ('P \& M'), vol 2, pp 487-8 'This [the murder fine] then became for a while the one and only meaning of murder; but probably in the popular mind that word still stood vaguely for homicide of the very worst kind.' [i.e. pre-meditated killing]. Whether the murder fine was just an example of 'morth', as opposed to being the source of the word, depends to a considerable extent whether the murder fine originated in the time of king Canute or in Norman times, see 9(f). It is likely the former. Holdsworth, n 65, vol 3, pp 312-3 failed to deal with Canute's agreement.

${ }^{89}$ Bosworth Toller, Anglo-Saxon Dictionary (online). “'morth' I. death. II that which causes death. III. Murder.' Also, spelt 'moro'. G Jacob, A New Law Dictionary $\left(7^{\text {th }}\right.$ ed, 1756) (murder) 'Murdrum from the Saxon morth, whence it is said, comes the barbarous latin mordrum and murdrum.' J Rastell, Les Termes de la Ley (1708) 'Murder is a willful killing of a man upon malice forethought, and seems to come of the Saxon word morden [morth] which it signifies.'

${ }^{90}$ The term 'pre-meditated killing' has spawned many synonyms such as 'malitia praecogitata' or 'malitia excogitata' (latin) 'malice prepense' (law French) 'malice aforethought', 'malice precedent' and 'premeditated malice'. The word 'aforethought' is the same as premeditation. OED, $\mathrm{n} 82$, (aforethought) 'Apparently introduced as an English translation of the old Law-Fr prepense in malice prepense. A. Thought before, entertained with mind beforehand; pre-meditated. B. Thinking beforehand, premeditation.'

${ }^{91}$ See Maitland, n 13, p 320. See also Book of Exodus, ch 21, v 14 (see 7(a)).

92 OED, n 82 (chance medley) 'AF chance medlee mixed or mingled chance or casualty;' Also '2. Law. Accident or casualty not purely accidental, but of a mixed character. Chiefly in manslaughter by chance-medley (for which later writers often use chance-medley itself); the causal killing of a man, not altogether without the killer's fault, though without an evil intent: homicide by misadventure; homicide mixt.'

${ }^{93}$ The connotation is that the killing arose from anger (hot blood), something reflected in the Biblical hebrew (see 7). See also Maitland, $\mathrm{n}$ 13, $\mathrm{p} 321$. Foster, $\mathrm{n}$ 77, p 276, chancemedley comprised 'a sudden casual affray commenced and carried on in the heat of blood.'

${ }^{94}$ Coke, $\mathrm{n} 44$, vol 3, pp 56-7 'Homicide is called chancemedley, or chancemelle, for that it is done by chance (without premeditation) upon a sudden brawl, shuffling, or contention: for meddle or melle (as some say) is an ancient French word, and signifies brawl, or contention. But I take it that the French word is mesle, which signifying shuffling or contending, and by corruption we changing the $\mathrm{S}$ to $\mathrm{D}$, do call it medle, the $\mathrm{S}$ not being pronounced, whereof we have made medletum. So as killing of a man by chance-medle, is killing of a man upon a sudden brawl or contention by chance, for the word [medle or melle] whereof we have made a latin word medletum or melletum, see Glanvill, lib 1 cap 2 cognoscere de medletis, de verberibus, de plagis: that is, of brawling, or brabling, of battery, of wounding: the first in words, the other two in strokes, etc in ancient time expressed by these two Saxon words, viz. flit a flitan, to brawl; and fiht, which we retain still to fight when it proceeds to blows. Unde flitwit, flichwite, fightwite etc.' [these were Anglo-Saxon fines for fighting]. See also TA Green, The Jury and the English Law of Homicide 1200-1600, Michigan LR (1976), no 74, p 467, n 200 
95 in order to distinguish it from murder. Chance medley was the basis of manslaughter when it covered intentional killing arising from provocation. The expressions often used in respect of it were fighting in 'hot blood' and 'on the sudden'.

Today, chance medley is obsolete - as well as the need to distinguish brawling as such - being separated into the concepts of provocation and self defence.

In conclusion, the history of the law of murder and manslaughter is not helped by changes in the meaning of terms.

\section{Benefit of Hindsight}

It is said that hindsight is a wonderful thing. And legal hindsight is even more pleasurable. Prior to reviewing the history of murder and manslaughter, it is useful - from the safe vantage of the present - to summarise what were the problems (and solutions) to the history of these crimes.

- Murder/Manslaughter. In hindsight, it would have been useful if Old Testament law, Anglo-Saxon law and early English law had not drawn a distinction between premeditated and unpremeditated killing. Instead, it would have been useful if they had developed the concepts of provocation and self defence as separate legal principles. Thus, the death penalty would have applied to all intentional killing - and been treated as murder - BUT, where it had been provoked, it would have been treated as manslaughter. And, where there was self-defence, it should have been treated as justifiable (i.e. no crime committed);

- $\quad$ Accidental \& Negligent Killing. In hindsight, these should have been separated out much earlier on. This would have allowed manslaughter to cover: (a) intentional killing where there was provocation; and (b) negligent killing;

- $\quad$ Reckless Killing. In hindsight, it would have been useful if this had developed the same time as negligent killing was treated as a separate category from accidental killing. ${ }^{96}$

The benefits can be seen in an example, which would have applied even in Anglo-Saxon times (indeed, in Babylonian times). A man drives a cart down a road. A child is sitting in the middle of it. If he runs over and kills the child:

- $\quad$ intentionally - it should be murder;

- recklessly - it should be manslaughter;

- $\quad$ negligently - there should be a legal duty to pay compensation (damages);

- $\quad$ accidentally - it should not be a crime.

As it is, over hundreds of years, English law has slowly (and painfully) developed these 4 categories. The good news is that they seem to work and that most (if not all) factual situations of killing can be fitted into them, such that juries (as well as judges and the accused) can comprehend these crimes more readily. Thus, these four categories should be enshrined in legislation.

\section{Babylonian Code}

It is important to commence any legal analysis of English law with reference to ancient law since the lex talionis - as well as the origins of the modern English law of murder and manslaughter - are to be found there. Maitland traced the nature of 'premeditated malice' to Anglo-Saxon law and then surmised that it may have derived from Old Testament law. ${ }^{97}$ Thanks to modern translations of the Old Testament and Anglo-Saxon law, this seems correct.

- However, it also seems clear the Old Testament took, at least, some of its criminal law from the Code of Hammurabi - one of earliest examples of written law yet discovered. ${ }^{98}$ Hammurabi was a Babylonian king who reigned from c.1792-50 BC (middle chronology);

- His Code - which is said to have antedated the laws of Moses in the Old Testament by c. 1000 years ${ }^{99}$ - was re-discovered on the acropolis of Susa in Persia in $1901 .^{100}$ It comprised some 282 commandments (statements of

\footnotetext{
(earliest reference to chance medley he found was in 1388). Also, J Skene, De Verborum Significatione (1597)(definitions of 'forthocht', 'chaud-melle' and 'melletum').

95 Pulton, n 42, p 120 'And the other is called manslaughter, or chance medley, and that is, when two men fight together upon a sudden heat of blood, without any malice precedent, and one of them does kill the other...'

96 Although Bracton (c. 1240) did refer to negligence in the context of killing, the first English legal writer who laid more stress on it was Hale, in the $17^{\text {th }}$ century, see $\mathbf{3 0}$.

${ }^{97}$ Maitland, n 13, pp 325-6.

98 See generally WW Davies, The Codes of Hammurabi and Moses (Cincinnati, 1905); C Edwards, The World's Earliest Laws (Watts \& Co, 1934); RF Harper, The Code of Hammurabi (1904, rep Law Book Exchange, 2010); CA Stern, Torah and Murder: The Cities of Refuge and Anglo-American Law, Valparaiso University LR (2001), vol 35, no 3, pp 461-98 and M Sulzberger, The Ancient Hebrew Law of Homicide (1913).

99 Hammurabi was the $6^{\text {th }}$ Amorite king of the First Dynasty of Babylon, who reigned for c. 43 years. In that era it seems that society was likely divided into: (a) the king (and officials); (b) the free person (awilu); (c) the commoner (muskenu) and (d) slaves. Status was reflected in the Code. Davies, $\mathrm{n} 98$, p 8 asserted that Hammurabi was a contemporary of the Biblical Abraham.

${ }^{100}$ It appears the pillar was originally erected in a temple at Sippara, near Bagdad, Iraq (now called Sippar, c. $30 \mathrm{~km}$ southwest of Bagdad). In c. 1200 BC, an Elamite king (Shutruk-Nahhunte I) sacked Sippara and took the pillar to Susa (now called Shush, in Iran), some 200 miles away. See also Davies, $\mathrm{n} 98$, pp 10-1; P Barmash, Homicide in the Biblical World (2005), p 2 and MT Roth, Law Collections from Mesopotamia and Asia Minor (Society of Biblical Literature, $2^{\text {nd }}$ ed, 1997).
} 
law) - 35 of which were missing - carved in the language of Babylon (akkadian) in 49 columns on a block of black diorite nearly eight feet in height. This stele is now in the Louvre, Paris. ${ }^{101}$

The Code dealt, inter alia, with criminal law. The general principle was that of the lex talionis. ${ }^{102}$ Although the Code did not separate killing into the following categories:

$$
\begin{aligned}
& \text { - } \quad \text { intentional; } \\
& \text { - } \quad \text { juscidental; } \\
& \text { - } \quad \text { excusable. }
\end{aligned}
$$

on a review of the Code, such is reasonable. As to killing:

- Intentional. Although the Code did not expressly state that intentional killing required a life for a life, ${ }^{103}$ this seems clear from the other commandments. Further, in some instances, negligent killing was treated the same as intentional killing - the death penalty applied. For example, a negligent builder was liable with his own life for anyone killed as a result of his negligent building; ${ }^{104}$

- $\quad$ Accidental. In the case of accidental killing, it seems that compensation - at least, sometimes - was sufficient. Further, negligent killing was treated, in the case of surgery, akin to accidental killing rather than to intentional killing. For example, if a doctor negligently operated on a man, causing him to die, he paid a penalty bodily. ${ }^{105}$ Also, and importantly for later English law, in the case of a fight (brawl) where a man struck another and killed him, compensation was sufficient, if it was not intentional. ${ }^{106}$ As to why the latter was not treated as intentional killing, one would suggest 4 practical reasons in particular:

- Loss of Manpower. If it was treated as intentional killing and the death penalty imposed, then, likely, there would have been too great a loss of manpower, since (one imagines) tavern brawls, martial fighting, challenges etc were common in Babylonian society;

- Two to Quarrel. It was likely that judges, and people, often viewed brawls as a matter of 'it takes two to make a quarrel', so that (in a sense) the victim, in many brawls, contributed to this own death; ${ }^{107}$

- Provocation \& Self Defence. A fight often involved an initial 'provocation' by one party with the other acting in 'self-defence'. These comprise mitigating circumstances where the killer had been provoked or acted in self-defence;

- Chance Element. Killing in a fight often involved an element of 'chance' (or Act of God) - one party lashing out and happening to kill the other. Thus, often, the killing was intentional (in a sense) - in that the parties intended to fight and must have been aware that, at least, some injury would result - but inadvertent as to the actual act which led to the death.

This statement of Babylonian law in respect of brawling - and it's not being treated as premeditated - is of great interest since (one would suggest), this concession flowed into Old Testament, Anglo-Saxon and English law (in the case of the latter, becoming, in more modern times, a matter of 'provocation' or falling into the category of excusable homicide since it was held to be by way of self-defence);

\footnotetext{
${ }^{101}$ The stele shows Shamash, the god of Justice, delivering his code to Hammurabi who stands before him (both have long beards). See Harper, $\mathrm{n} 98$, frontispiece. The Code also contained curses against those who did not obey, or who altered, his commandments (the lord of the heavens laid a 'sin' upon him). This has considerable similarities to God handing his commandments to Moses in the Old Testament. Further, since the distance between Bagdad (where the stele was originally located) and Jerusalem is c. $540 \mathrm{~km}$, there would have been considerable social, and legal, interaction such that it is legitimate to assert that Mosaic law derives, in part, from Babylonian law. See also Edwards, n 98, Preface.

102 e.g. Edwards, n 98, No 196 'If a man has destroyed the eye of a freeman, his own eye shall be destroyed.' No 197 'If he has broken the bone of a freeman, his bone shall be broken'. No 200 'If a man has knocked out the teeth of a man of the same rank, his own teeth shall be knocked out.' Provision was made as to status and family relationships in these matters (e.g. if a son struck his father his hands were cut off, see No 195).

${ }^{103}$ Edwards, $\mathrm{n} 98, \mathrm{p} 121$ thought the reason was that this crime was extrajudicial (i.e. for the kin to revenge). Ibid, $\mathrm{p} 113$ 'it is pretty certain that in Babylonia willful homicide was a family matter with which the judicature was not allowed to interfere. If it had been customary to compound for the crime, we may be sure that the legislator would have made some attempt to regulate the blood price...' A Phillips, Ancient Israel's Criminal Law (1970), p 86 'murder itself was not treated as a crime, but as a matter for the relatives of the deceased.' Also, Sulzberger, n 98, pp 6, 14. See also an earlier Code, the laws of Ur-Namma (c. 2100 BC), no 1 'If a man commits a homicide, they shall kill that man.' See Roth, n 100, p 17.

${ }^{104}$ Edwards, n 98, pp 44-5, No 229 'If a builder has built a house for a man and his work is not strong, and if the house he has built falls in, and kills, the householder, that builder shall be slain.' No 230 'If the child of the householder be killed, the child of that builder shall be slain.' No 231 'If the slave of the householder be killed, he shall give slave for slave to the householder.'

${ }^{105}$ Ibid. No 218. 'If a doctor has treated a man with a metal knife [i.e. by surgery] for a severe wound, and has caused the man to die, or has opened a man's tumor with a metal knife and destroyed the man's eye, his hands shall be cut off.'

${ }^{106}$ Ibid, No 206 'If a man has struck another man in a dispute and wounded him, that man shall swear 'I did not strike him knowingly' [i.e. it was accidental] and he shall pay for the doctor. No 207 'If he die of his blows, he shall swear likewise; and if it be the son of a freeman, he shall pay half a mina of silver.' No 208 'If he be the son of a plebian, he shall pay a third of a mina of silver.' See also Roth, n 100, p 122 who translates no 206 as 'If an awilu should strike another awilu during a brawl and inflict on him a wound, that awilu shall swear 'I did not strike intentionally', and he shall satisfy the physician (i.e. pay his fees).' See also DP Wright, The Laws of Hammurabi and the Covenant Code: A Response to Bruce Wells, Marrav 13.2 (2006), pp 211-260 (this article is available online), p 225 who translates no 206 as 'If an awilum strikes another awilum in a fight and injures him, that awilum shall swear (saying), 'I did not strike him with intent' and he shall pay the physician.' The akkadian word 'risbatim' is translated as 'dispute', 'brawl', 'fight' (being synonyms) - just as the later Middle English word 'brawl' (see OED, n 82 (brawl) 'a noisy, turbulent, quarrel') translates the Anglo-Saxon 'fiht' or 'fight'.

${ }^{107}$ This approach was also reflected in early English law. See e.g. $\mathrm{n} 298$ (Laws of Henry I c. 1113).
} 
- Justifiable. Doubtless, Babylonia was as violent as Old Testament Israel or Anglo-Saxon England. Further, since the State (king) did not (mainly) concern himself with criminal law, leaving this to the tribe and kin, it is not surprising that - to secure criminal justice in those times - certain killings were held to be justifiable. That is, no crime was treated as committed. The Code did not indicate that a killing was justifiable:

- $\quad$ pursuant to due legal process, that is, where ordered by the king's judges or elders of the community. However, this must have been implicit. Otherwise, no legal system with a death penalty could function;

- $\quad$ pursuant to lawful revenge (the blood feud). ${ }^{108}$ However, this must also have been implicit.

The Code made it clear that it was justifiable to kill a:

- man breaking into one's house (an assassin or burglar); ${ }^{109}$

- $\quad$ highway robber (brigand, bandit); ${ }^{110}$

- $\quad$ thief, in most cases; $;^{11}$

- $\quad$ adulteress caught in the act (in flagrante); ${ }^{112}$

- $\quad$ perjurer, in a capital case; ${ }^{113}$

- $\quad$ sorcerer (one who killed with a curse or poison). ${ }^{114}$

In the cases of perjury and sorcery (in a society which believed that death could be caused by a curse or spell) ${ }^{115}$ and highway robbery, it is understandable why killing was justifiable:

- $\quad$ Sought to Avoid Lex Talionis. These acts would have been taken as particularly heinous - being inspired by a prior malice against the victim, wishing to do them harm. Further, the modus operandi of these acts was designed to avoid the payment of compensation since the killer was seeking to remain unknown (secret). Why, then, should such persons - now they had been caught - be entitled to pay compensation in lieu of the death penalty, when compensation was the very thing they had sought to avoid?

- Public Outrage. One can also surmise that, in Babylon (as in Anglo-Saxon and medieval England), there was public revulsion against brigands, sorcerers and poisoners, such that the law adopted a 'hard line' to suppress behaviour which also affected the security of society in general.

Finally, it may be noted that - in the case of a person ambushed and killed on a highway by an unknown killer - the community was required to pay a fine to the victim's kin. ${ }^{116}$ This concept was to re-surface as the 'murder fine' in Anglo-Saxon (and early medieval) law.

- $\quad$ Excusable. The Code did not indicate whether it was a defence (or not a crime) to kill another: (a) in self defence; or (b) in defence of one's family and kin. However, one would suggest that this basic principle must have been accepted. Also, that it would, likely, have been treated as an aspect of accidental killing, in that there was no intention to kill.

\footnotetext{
${ }^{108}$ See $\mathrm{n} 10$.

${ }^{109}$ Edwards, $\mathrm{n}$ 98, No 21 'If a man has broken into a house, before the breach [entrance to the house] shall he be slain [i.e. summary execution], and there buried.' See also the translation of Roth, n 100, p 85 'If a man breaks into a house, they shall kill him and hang him in front of that very breach.' In the case of a person breaking into a house at night, there is no means of determining their intention since it could be to kill or to steal. Likely, in Babylonian (and later societies) it was often the former. Thus, the killing of such a person was treated as a form of self defence.

${ }^{110}$ Ibid, No 22: 'If a man has perpetrated brigandage [highway robbery], and has been caught, that man shall be slain. No 23 'If the brigand has not been taken, the man plundered shall claim before God what he has lost.' No 24 'If a life, the city and sheriff shall pay one mina of silver to his people'. It has been conjectured that this means that - in the case of a person killed on the highway where the killer was unknown - the community was obliged to compensate. See also Roth, n 100, p 85 who uses the word 'robbery'. Also, OED, n 82 (brigandage) 'The practice of brigands; highway-robbery, freebooting, pillage.'

${ }^{111}$ Edwards, n 98, No 6 'If a man steal the goods of a god [temple goods], or a great house [possibly, from the house of a freeman], that man shall be slain'. No 8 'If a freeman has stolen an ox, or a sheep, or an ass, or a pig, or a boat, either from a god or a great house, he shall pay thirty-fold. If he be a plebian, he shall render ten-fold. If the thief has nothing to pay, he shall be slain.' No 14 'If a man has stolen a man's son under age [child kidnapping], he shall be slain.' See also Nos 7, 10, 25 .

112 Ibid. No 129 'If the wife of a man is found lying with another male, they shall be bound and thrown into the water [i.e. drowned]; unless the husband lets his wife live, and the king lets his servant live.' There was probably also a practical reason for this being justifiable homicide. It pre-empted an outraged husband from intentionally killing and, thereby, setting up a blood feud.

113 Ibid. No 3 'If in a lawsuit a man gives false evidence, and the word he has spoken is not justified: then if that case involve a life [i.e. a capital case], that man shall be slain.' See also Davies, $\mathrm{n} 98$, pp 24-5. Roth, $\mathrm{n}$ 100, $\mathrm{p} 81$ 'If a man comes forward to give false testimony in a case but cannot bring evidence for his accusation, if that case involves a capital offence, that man shall be killed.'

114 Ibid. No 1 'If a man has laid a curse upon another man, and it is not justified, the layer of the curse shall be slain'. No 2 'If a man has thrown a spell upon another man, and it is not justified, he who has suffered the spell shall proceed to the holy river: into the holy river shall he plunge. If the holy river seize him [i.e. he drowns], the layer of the spell shall take his house. If the holy river hold him guiltless, and he remains unharmed, the layer of the spell shall be slain. He that plunged into the holy river shall take the house of the layer of the spell.'

115 Davies, n 98, p 23 'The fact that the code opens with laws against magic or sorcery seems to prove the prevalence of such practices among the early Babylonians, and the severity of the penalty is a clear proof that the people were superstitiously afraid of those who practiced magic.' Edwards, $\mathrm{n} 98$, pp 68-9 indicated that the Babylonians distinguished between bad spells (curses, nertu) and good ones (kispu). The latter were those which the medicine man (doctor) used to heal. Edwards, n 98, p 68 'His method of procedure was usually to pronounce a counter spell upon the suspected wizard.'

${ }^{116}$ See n 110, no 24. It has been conjectured this commandment no 24 means that - in the case of a person killed on the highway where the killer was unknown - the community was obliged to compensate. See also Davies, n 98, p 34. It is likely brigands (bandits) were a major problem. Edwards, $\mathrm{n} 98$, p 70 'Ancient Babylonia was badly policed, and brigandage was common.' See Ibid, p 15.
} 
In conclusion, Babylonian law was fairly rudimentary and the overriding principle was that of the lex talionis (albeit the latter - being a system of 'equivalent' compensation - was an improvement on what was probably unbridled revenge killing by the victim's kin prior to it). ${ }^{117}$

\section{Old Testament Law}

The 'criminal' law in the Old Testament closely followed Babylonian law in some aspects. In others, it was a considerable advance.

\section{(a) Biblical Statements}

Following the lex talionis (but unlike Babylonian law which made no express provision), the Old Testament stated:

If anyone takes the life of a human being, he must be put to death... whoever kills a man must be put to death. ${ }^{118}$

Despite this pre-emptory declaration (a classic statement of the lex talionis in all its starkness) Old Testament law did distinguish between intentional and accidental killing as well as (to some extent) killing arising from negligence. ${ }^{119}$

\section{(i) Book of Exodus (c. 1446 BC)}

Maitland - reviewing the early history of malice aforethought ${ }^{120}$ - referred to the Book of Exodus, chapter 21, verse $14,{ }^{121}$ for the possible origin of the concept of murder. He stated:

Our authorized version [i.e. King James version, Book of Exodus] renders it thus: 'But if a man come presumptuously upon his neighbour, to slay him with guile; ${ }^{122}$ thou shalt take him from mine altar that he may die.' In the Vulgate the words are 'Si quis per industriam occiderit proximum suum, et per insidias, ab altari meo evelles eum, ut moriatur.' ${ }^{123}$ (underlining supplied)

Maitland also stated:

...It is not impossible that the texts in the Vulgate about insidiae are the root of the whole matter, the cause why the notion that murder is slaying in secret, or slaying with concealment, was after the formation of the Canon law replaced by the theory that the differentia of the worst homicide is... premeditatus assultus [i.e. premeditated assault]. ${ }^{124}$

One would agree. Indeed, a more modern (and more accurate) translation from the Book of Exodus - including the prior sentences to that quoted by Maitland - states: ${ }^{125}$

Anyone who strikes a man and kills him shall surely be put to death (verse 12). ${ }^{126}$

\footnotetext{
${ }^{117}$ As Barmash, n 100, p 11 noted, the lex talionis was 'a principle of equivalence, not of harsh justice.' Also, pp 7-8 'Blood feud was a legal mechanism, not an aberration outside of the law... [it] is by its nature rule bound. The potential for violence actually limits violence and promotes the acquiescence of the killer to a trial. In a society without specialized juridical personnel, such as police or prosecutors, a lineage acting as a mutual aid society ensures that the crime would be punished.' See also Davis, n 5, p 33 (citing another commentator HD Betz 'The original purpose of the talio then was to limit or eliminate revenge and set up a new system of justice, which would be obtained by 'proportional punishment' or by 'substitutional compensation.' Further, it is unclear the extent to which Babylonian (and, indeed, Old Testament) law permitted the victim's family to compensate. For example, an 'eye for an eye' can mean physical compensation or the money value of an eye. As previously indicated, $\mathrm{n} 7$, to prevent loss of manpower and a widespread number of cripples, it was likely that, in Babylonia, acceptance of compensation was urged on the kin.

${ }^{118}$ NIV, n 6, Book of Leviticus, ch 24, vv 17, 21. Davis, n 5, p 48 'Capital punishment for the case of murder is presented as an equitable and proportional penalty.' See also Book of Genesis, ch 9, v 6 (see n 6). Stern, $\mathrm{n}$ 98, p 465 'Genesis 9:6 demands capital punishment for shedders of blood.' See also Phillips, n 103, D Daube, Studies in Biblical Law (1969). The same basis principle applied to injuries. Ibid. Book of Exodus, ch 21 v 23 'But if there is serious injury, you are to take life for life, eye for eye, tooth for tooth, hand for hand, foot for foot, burn for burn, wound for wound, bruise for bruise.' Book of Leviticus, ch 24, v 19 'If anyone injures his neighbour, whatever he has done must be done to him: fracture for fracture, eye for eye, tooth for tooth. As he has injured the other, so he is to be injured.' Book of Deuteronomy, ch 19, v 21 'life for life, eye for eye, tooth for tooth, hand for hand, foot for foot.'

${ }^{119}$ The concept of negligent killing was undeveloped. Book of Exodus, ch 21, v 28. If a bull gored a person to death it was to be stoned. But if it had the habit of goring and the owner had been warned but not penned it and it killed a person 'the owner also must also be put to death. However, if payment is demanded of him, he may redeem his life by paying whatever is demanded.' Cf. Babylonian law, Edwards, n 98, No 251 'If a man's ox is known to be addicted to goring, and he has not blunted his horns, nor fastened up his ox, then if his ox has gored a free man and killed him, he shall give half a mina of silver.' Also, p 121. Jewish law did not appear to deal with negligent builders, see n 104(Babylonian law).

${ }^{120}$ See $\mathrm{n} 13$.

${ }^{121}$ The 'Exodus' referred to is that of the Israelites from Egypt which is thought to have occurred c. 1446.

122 'Presumptuously' is rather archaic, the Revised Standard Version used the word 'wilfully.' As to 'guile', it was a synonym for 'malice' and closely connected with 'hatred'. See also NIV, n 6, Book of Leviticus, ch $19 \mathrm{vv}$ 16-18 'Do not do anything that endangers your neighbour's life...Do not hate your brother [i.e. your neighbour] in your heart... Do not seek revenge or bear a grudge against one of your people, but love your neighbour as yourself.' (italics supplied). Reference to 'hatred' and to bearing a 'grudge' were to malice (latin, insidias) which was evidence of premeditation. See also Gospel of Mark, ch 7, vv 21-2 'For from within, out of men's hearts, come evil thoughts [intentions]...murder...malice [wicked deeds]'.

${ }^{123}$ This wording implies that - where the killing was not pre-meditated and the killer fled to sanctuary (the temple) - he could not be taken from the temple, in order for death pursuant to the lex talionis to be imposed forthwith. 'Per industriam' can best be translated as 'intentionally' or 'on purpose'. Lewis \& Short, A Latin Dictionary (Oxford, 1890)(definition of industriam).

${ }^{124}$ See n 13, p 325 .

${ }^{125}$ Also, Maitland did not state the prior sentences in the passage from the King James version he cited which help explain the position. They state: 'He that smiteth a man, so that he die, shall be surely put to death. And if a man lie not in wait, but God deliver him into his hand; then I will appoint thee a place whither he shall flee. (italics supplied). 'Lie in wait' is an example of premeditation.

${ }^{126}$ The Vulgate, $\mathrm{n} 81$, states 'qui percusserit hominem volens occidere morte moriatur'. The Vulgate imports the word 'volens', since verse 13 deals with the opposite situation, where the striking is not intentional. In respect of this verse 12, the Hebrew uses the word makkeh (or makkah) ('he who attacks') with the root word 'nakah' meaning to attack, smite, strike. And, like the latin translation, although the hebrew does not make direct reference to
} 
However, if he does not do it intentionally, ${ }^{127}$ but God lets it happen [i.e. by chance], he is flee to a place I will designate. (verse 13) ${ }^{128}$

But if a man schemes ${ }^{129}$ and kills another man deliberately, ${ }^{130}$ take him away from my altar and put him to death. ${ }^{131}$ (verse 14) (italics supplied)

Both Babylonian, and Old Testament, law (see verse 12 above) reflected the basic premise 'Thou shalt not kill' ${ }^{132}$ with the commensurate punishment being - in accordance with the lex talionis - that one who kills shall die, by way of equivalent satisfaction (atonement). However, to prevent this being excessively draconian, both laws made a primary distinction between: (a) intentional; and (b) accidental, killing. ${ }^{133}$ Further, in respect of both laws there was a bi-furcation in intentional killing between:

(i) premeditated (in 'cold blood') and;

(ii) non-premeditated (in a fight, in 'hot blood').

One would expect to find (ii) in early laws since, implicit in it, is the reasonableness that a man has a right to defend his own life ('self-defence'). Also, that 'provocation' should mitigate the punishment. The passage from the Book of Exodus quoted above cites both the primary principle of a life for a life, as well as the bi-furcation. As to this:

- Babylonian Origin - Killing in Hot Blood. Babylonian law (commandment no 206) provided that - if a person should kill another in a brawl, fight, quarrel (akkadian, risbatim) ${ }^{134}$ - the penalty was not death, if the striking was not intentional. The above passage from Exodus corresponds with Babylonian law ${ }^{135}$ and verses 12 and 13 - as opposed to verse 14 - suggest the former are dealing with the punishment for an attack in 'hot blood' (hebrew, zid). Here sanctuary (compensation) is permitted. However, verse 14 is dealing with an attack in 'cold blood' (premeditated, with guile, hebrew bearemah). Here, no sanctuary is permitted, the killer must forfeit his life. The reference in the hebrew to 'lie in wait' (hebrew, sadah) translated by the latin 'insidiae'136 - is illustrative, an example of scheming or plotting. As will be seen, Anglo-Saxon law (see 9) - closely following the Old Testament treated homicide as being either 'open' (as in a fight) or 'secret'. The latter was described by the word 'morth', from which derived the English 'murder';

In short, all these laws distinguished premeditated from unpremeditated killing with, in particular, killing in a fight (in hot blood) as being less a matter of intention than of chance and, thus, being less reprehensible and meriting compensation rather than death. And, as previously noted (see 6), one would suggest that (as in Babylonian law) the policy reasons for this were: (i) to save manpower; (ii) a general perception that it took two to quarrel and (iii) quarrels often resulted from provocation and a person acting in self-defence. Thus, the English word 'premeditation' - as well as the older English synonym 'aforethought' - sums up the distinction the Book of Exodus was seeking to make between a plotted killing and one which, although intentional (in a sense), was more akin to chance (being also, likely a matter of accident as well). That is, an act not being plotted - such as in a brawl, one in the heat of the moment and unanticipated;

- Moral Connotation - Wickedness. Babylonian law on homicide does not appear to reflect any moral stance as such. However, the Old Testament, being a work of theology did. A premeditated (plotted) killing was a secret one - one in which the killer sought to avoid detection. This was abhorrent to the Old Testament religious world, in

\footnotetext{
intention, this is implicit. See Biblia Hebraica Stuttgartensia (Deutsche Bibelgesellschaft, $5^{\text {th }}$ amended ed, 1997) Also, J Strong, Strong's Hebrew Dictionary of the Bible (2013 rep).

${ }^{127}$ NIV, n 6, a footnote to this sentence in Exodus, ch 21, v 13 states: 'Related terms and expressions are 'accidentally' (Nu 35:11), 'without hostility' (Nu 35:22), 'was not his enemy' (Nu 35:23), 'did not intend to harm him' (Nu 25:23) and 'without malice aforethought' (Dt 19:4). Pre-meditated murder is thus distinguished from accidental manslaughter. God lets it happen. The event is beyond human control - in modern legal terminology, an 'act of God'.'

${ }^{128}$ The Vulgate, $\mathrm{n} 81$, states 'qui autem non est insidiatus sed Deus illum tradidit in manu eius constituam tibi locum que fugere debeat.' The Hebrew does not refer to 'intentionally' in verse 13 but that a person did not 'lie in wait' (sadah), reflecting that there was no premeditation. The hebrew also referred to (literally) 'deliver [him] into his [God's] hand'. This concept of Act of God ('God lets it happen', see $\mathrm{n}$ 127) is likely the origin of 'chance' in 'chance medley', see n 92. See also Sulzberger, n 98, p 22 'sadah, the term employed to describe the wily tactics of the hunter who pursues his game....a man hunt.'

129 The Hebrew word bearemah (the 'e'’s are inverted) signified acting with guile. Implicit in the concept is that of acting secretly. The English word 'guile' is thought to be of Teutonic origin with the senses of 'insidious cunning, deceit, treachery', see OED, n 82. See also Sulzberger, n 98, pp 22, 37-8.

${ }^{130}$ The latin uses for 'deliberately' (intentionally) 'per industriam', see n 123. The Hebrew refers to 'wilfully attacks' (yazid). See also Sulzberger, $\mathrm{n}$ 98, p 22. Also, p 38 'Coming presumptuously is called yazid, a word likewise used in other passages to express insolent defiance of law or right.'

131 See also NIV, n 6, Book of Deuteronomy, ch 27, v 24 'Cursed is the man who kills his neighbour secretly' The reference in modern translations to 'kills... secretly' is taken as a reference to murder. D Patrick, Old Testament Law (SCM Press Ltd, 1985), p 73 considered the reference to scheming and deliberate killing was 'equivalent to our phrase, "malice of forethought."

132 See Book of Exodus, ch 20, v 13 (ten commandments) 'Thou shall not kill' (King James version).

${ }^{133}$ For accidental killing and references to the same, see the Books of Deuteronomy, Numbers, Joshua, see (ii)-(iv).

134 See n 106.

135 See Wright, n 106, p 225 in which the texts are compared.

${ }^{136}$ Lewis \& Short, n 123, (definition of insidiae) It connoted 'artifice, crafty device, plot, snare' as well as being used as a word for 'an ambush'. See also, 'insidiosus' (adj), 'cunning, artful, deceitful, dangerous, insidious.' Implicit within the word is the idea of a person not acting openly but, rather, secretly. See also n 128.
} 
which the spilling of blood - even accidentally ${ }^{137}$ - was a crime since it comprised spiritual pollution. Further, secret killing was a $\sin$ - the very sin of Cain ${ }^{138}$ since it prevented atonement by way of the payment of compensation, the death being unknown. As a result, it defeated the purpose of compensation which was designed to observe the legal symmetry comprising the lex talionis, that there must be like for like in some way, in the case of punishment. ${ }^{139}$ The only means to re-address this was to ensure that the killer was himself killed. ${ }^{40}$ This also reflected the moral outrage of God against such a heinous act. As a result, it is unsurprising that such an act was treated in the Bible as flowing from the heart (the seat of the emotions) by way of hatred, enmity, malice, And, therefore, it was categorised as wicked, sinful, malicious, morally perverted and wrong. Thus, the epithet 'malice' in the expression 'premeditated malice' ('malice aforethought', 'malitia praecogitata') - although it added nothing in legal terms (as Maitland noted) - likely reflected the theological outrage behind such an act and it is not surprising to see it used in English law, which - from Anglo-Saxon up to Victorian times - often reflected the notion that many crimes were acts of wickedness. ${ }^{141}$

Therefore, under Old Testament law (like Babylonian law), premeditated killing merited death. However, what - to the Old Testament mind - comprised evidence of premeditation? This seems clear. If it could be shown that the killing was:

- $\quad$ schemed (plotted) - such as by way of an ambush (brigandage) $;^{142}$

- $\quad$ in secret (such as concealing the body or by means of poison, sorcery or false witness, see (d)); or

- the killer was shown to have had prior malice (hatred in his heart) for the victim. ${ }^{143}$

In conclusion, one would suggest that the Book of Exodus closely followed Babylonian law. The basic principle was the lex talionis (a life for a life). A killer, however, could avoid this (and could avail himself of sanctuary, to permit an impartial judgment of his case) if he could show that his killing was accidental (which included negligence). Further, killing in a brawl was likely treated (as in Babylonian law) as accidental, if a killer could prove he had had no prior intention to kill.

\section{(ii) Book of Deuteronomy (c. $8^{\text {th }}-6$ c BC)}

The Book of Exodus referred to 'a place I will designate'. Initially, this would likely have been some sacred spot, such as an altar or temple. However, later, 'cities of refuge' were specified. Thus, the Book of Deuteronomy, ${ }^{144}$ chapter 19 , verse 1 onwards provides:

When the lord your God has destroyed the nations whose land he is giving you, and when you have driven them out and settled in their towns and houses, then set aside for yourselves three cities centrally located in the land the Lord your God is giving you to possess. ${ }^{145}$ Build roads to them and divide into three parts the land the Lord your God is giving you as an inheritance, so that anyone who kills a man may flee there.

This is the rule concerning the man who kills another and flees there to save his life - [one who kills his neighbour unintentionally, without malice aforethought.] ${ }^{146}$ For instance, a man may go into the forest with his neighbour to cut wood, and as he swings his axe to fell a tree, the head may fly off and hit his neighbour and kill him. That man

\footnotetext{
${ }^{137}$ Barmash, n 100, p 9 'Even an accidental killing polluted. According to the priestly traditions, this meant that the accidental killer was forced to remain in a city of refuge until the death of the high priest: his death acted as expiation for the contamination incurred by the accidental death.' For the concept of pollution through the spilling of blood, see Ibid, ch 4 .

${ }^{138}$ Ibid, ch 1. NIV, n 6, Book of Genesis, ch 4, v 8 'Now Cain said to his brother Abel, 'Let's go out to the field. And while they were in the field, Cain attacked his brother Abel and killed him'. Thus, the killing was pre-meditated and by burying him secretly Cain sought to defeat the law (the lex talionis requiring compensation). God, therefore, must take vengeance. He says to Cain (v 10) 'What have you done? Listen! Your brother's blood cries out to me from the ground. Now you are under a curse' [the blood feud, since Abel's death must be avenged by blood for blood]. Cain accepts (v 14) 'whoever finds me will kill me.' Since he is the closest male kin and there is no one else to avenge Abel's death, any other male in the community must avenge it, to atone for the spilling of blood. In short, Cain was the first murderer. Also, the first outlaw - one without any legal rights or protection and with a blood price on his head. The story illustrates the principle of very early law. If a killing was done so that compensation could not apply, the most basic tenet of the lex talionis must be enforced (life for life) by way of summary vengeance against the killer by anyone.

${ }^{139}$ Barmash, n 100, pp 157-8 'Lex talionis, then, expresses a principle of legal symmetry, of repaying in kind.'

${ }^{140}$ Ibid, p 159 'the embodiment of lex talionis: the killer is himself killed... The only way the spilling of blood can be undone is for the blood of the offender to be spilled as a punishment.' See also Sulzberger, n 98, p 42.

${ }^{141}$ Maitland thought that 'malice' was a word which simply 'swelled the charge' (see n 398). He thought that the expression 'malice aforethought' started arising in English law c 1270 (see text to n 395). The word 'malice' was not found as such in Anglo-Saxon law, unless it could be said to be implicit in the concept of 'morth' (see n 88).

${ }^{142}$ See also n 110 (Babylonian law). Sulzberger, n 98, p 64 (following the Book of Deuteronomy, the act of a murder was an act of killing a hated person...by lying in wait for him.'

${ }^{143}$ Sulzberger, n 98, p 84 sums this up by noting that the important elements for murder in the Old Testament were: prior enmity, lying in wait, an insolent (presumptuous) purpose (intent) to kill, a deliberate preparation for carrying the purpose into effect. All these flowed into English law in the forms of 'premeditated assault' and 'premeditated malice.'

144 The date of this Book has always been uncertain and it is thought to have undergone a process of expansion over time, with the aggregation of additional matter including, possibly, legal material. Barmash, n 100, pp 71, 82 considered that it reflected legal practice $\mathrm{c} .7^{\text {th }}$ century. This Book located the Israelites in the land of Moab (where the Jordan flows into the Dead Sea) with Moses preparing to transfer leadership to Joshua as the Israelites made ready to enter the land of Canaan.

145 See also Patrick, n 131, pp 123-6.

146 The King James version, v 4 states: 'Whoso killeth his neighbor ignorantly, whom he hated not in time past.' The Vulgate, $\mathrm{n} 81$, uses the words 'nesciens' (unwillingly) and 'et qui heri et nudius tertius nullum contra eum habuisse odium comprobatur'. The hebrew uses the word daat [bibli], meaning 'unintentionally' or 'without knowledge'. See also E Neufeld, The Hittite Laws (1951), p 1.
} 
may flee to one of these cities and save his life. Otherwise, the avenger of blood ${ }^{147}$ might pursue him in a rage, overtake him if the distance is too great, and kill him even though he is not deserving of death, [since he did it to his neighbour without malice aforethought.] ${ }^{148}$ This is why I command you to set aside for yourselves three cities ... 149

[But if a man hates his neighbour and lies in wait for him, assaults and kills him, $]^{150}$ and then flees to one of these cities, the elders of his town shall send for him, bring him back from the city, and hand him over to the avenger of blood to die. Show him no pity. You must purge from Israel the guilt of shedding innocent blood, so that it may go well with you. (wording divided and underlined supplied)

In conclusion - as with the Book of Exodus - in the Book of Deuteronomy a distinction was made between accidental and premeditated (secret) killing. The designation of 'cities of refuge'- which had elders who judged the crime and were likely more impartial than the local village elders where the crime occurred - was a legal advance. ${ }^{151}$

\section{(iii) Book of Numbers}

The Book of Numbers (of uncertain date), ${ }^{152}$ chapter $35, \mathrm{v} 9$ onwards provides:

Then the Lord said to Moses: Speak to the Israelites and say to them: 'When you cross the Jordan into Canaan, select some towns to be your cities of refuge, to which a person who has killed someone accidentally ${ }^{153}$ may flee. They will be places of refuge from the avenger, so that a person accused of murder may not die before he stands trial before the assembly. ${ }^{154}$ These six towns you give will be your cities of refuge. Give three on this side of the Jordan and three in Canaan as cities of refuge. ${ }^{155}$ These six towns will be a place of refuge for Israelites, aliens and any other people living among them, so that anyone who has killed another accidentally can flee there. ${ }^{156}$

If a man strikes someone with an iron object so that he dies, he is a murderer; the murderer shall be put to death. Or if anyone has a stone in his hand that could kill, and he strikes someone so that he dies, he is a murderer; the murderer shall be put to death. Or if anyone has a wooden object in his hand that could kill, and he hits someone so that he dies, he is a murderer; the murderer shall be put to death. The avenger of blood shall put the murderer to death; when he meets him, he shall put him to death. [i.e. presumption of premeditation] ${ }^{157}$

[If anyone with malice aforethought pushes another or throws something at him intentionally so that he dies or if in hostility [anger] he hits him with his fist so that he dies, that person shall be put to death; he is a murderer.] ${ }^{158}$ The avenger of blood shall put the murderer to death when he meets him. But if without hostility someone suddenly pushes another or throws something at him unintentionally or, without seeing him, drops a stone on him that could kill him, and he dies, then since he was not his enemy and he did not intend to harm him, the assembly must judge between him and the avenger of blood according to these regulations. The assembly must protect the one accused of murder from the avenger of blood and send him back to the city of refuge to which he fled.

He must stay there until the death of the high priest, who was anointed with holy oil. But if the accused ever goes outside the limits of the city of refuge to which he has fled and the avenger of blood finds him outside the city, the avenger of blood may kill the accused without being guilty of murder. The accused must stay in his city of refuge until the death of the high priest; only after the death of the high priest may he return to his own property.

\footnotetext{
${ }^{147}$ NIV, n 6, p 314 states, in a note to Joshua, ch 20, v 1: 'Also translated 'kinsman-redeemer' (Ru 3:9) or 'Redeemer' (Ps 19:14). The avenger was a near relative with the obligation of exacting retribution (see Lev 24:17; Nu 35: 16-28).' Barmash, n 100, p 23 'In biblical Israel, the victim's family assumed primary responsibility for ensuring that the slayer was held accountable for his offence. A member of the family had the right and responsibility to kill the slayer and could do so with impunity under certain conditions.' See also Stern, n 98, p 465 (redeemer of blood, one who made atonement).

${ }^{148}$ The King James version, $\mathrm{v}$ 6, states: 'inasmuch as he hated him not in time past.' The Vulgate, $\mathrm{n} 81$, refers to 'quia nullum contra eum qui occisus est odium prius habuisse monstratur.' Davis, $\mathrm{n} 5, \mathrm{p} 45$ 'The person who accidentally kills is described as being 'innocent blood'. Thus an action to kill the manslayer would result in the 'guilt of bloodshed.'

${ }^{149}$ It continues 'If the Lord your God enlarges your territory...then you are to set aside three more cities. Do this so that innocent blood will not be shed in your land, which the lord your God is giving you as your inheritance, and so that you will not be guilty of bloodshed.'

${ }^{150}$ The King James version, $v 11$ states: 'But if any man hate his neighbor and lie in wait for him, and rise up against him, and smite him mortally that he die...' The Vulgate, $\mathrm{n} 81$, refers to 'si quis autem odio habens proximum suum insidiatus fuerit vitae eius surgensque percusserit illum et mortuus fuerit.' See also Sulzberger, $\mathrm{n} 98, \mathrm{p} 24$

${ }^{151}$ Phillips, $\mathrm{n} 103$, pp 106-7 noted that there was a central appeal court in Jerusalem comprising laity and priests. Therefore, it seems likely that, where the case (including homicide) was too difficult for the elders in the city of refuge, it came to this court. See also Book of Deuteronomy, ch 17, v 8 and Barmash, n 100, p 34 .

${ }^{152}$ The Book of Numbers relates the story of the Israelites journey from Mount Sinai to the plains of Moab on the border of Canaan. Much of its legislation is similar to that in Exodus, Leviticus and Deuteronomy. See NIV, n 6, p 184. Also, Hale, n 45, pp 2-3.

${ }^{153}$ The hebrew word used is bisgagah (accident), meaning 'in error, unintentionally, in ignorance'. See also Neufeld, n 146, p 1.

${ }^{154}$ The NIV, n 6, p 314 states, in a fn 'assembly. Made up of the adult males of the city. Their function in the trial before the elders...is not clear, but perhaps they witnessed the trial to see that it was fair (closed courts are notoriously corruptible).'

${ }^{155}$ The 6 towns were Kedesh, Golan, Ramoth, Shechem, Bezer and Hebron. See NIV, n 6, p 238.

${ }^{156}$ The Vulgate, $\mathrm{n} 81$, uses the word 'nolentes' (unwilling) for accident. The Hebrew uses the word bisgagah (accident), see 153. See also Sulzberger, $\mathrm{n}$ $98, \mathrm{p} 25$.

${ }^{157}$ See Stern, $\mathrm{n} 98, \mathrm{p} 471$ referring to The Principles of Jewish Law (Manachem Elon ed, 1975), p 475 (these examples raise conclusive presumptions of murder). See also Barmash, n 100, p 121

${ }^{158}$ The King James version, vv 20-1 'But if he thrust him of hatred, or hurl at him by laying in wait, that he die; or in enmity smite him with his hand, that he die...' The Vulgate, $\mathrm{n} 81$, refers to 'si per odium quis hominem inpulerit vel iecerit quippiam in eum per insidias aut cum inimicus manu percusserit...'

${ }^{159}$ As the NIV, $\mathrm{n}$ 6, pointed out in a footnote, $\mathrm{p} 238$, not even an accidental killer could leave a city of refuge on the payment of a ransom (compensation).
} 
These are to be the legal requirements for you throughout the generations to come, wherever you live. Anyone who kills a person is to be put to death as a murderer only on the testament of witnesses. But no-one is to be put to death on the testimony of only one witness. Do not accept a ransom for the life of a murderer, who deserves to die. He must surely be put to death. Do not accept a ransom for anyone who has fled to a city of refuge and so allow him to go back and live on his own land before the death of the high priest. Do not pollute the land where you are. Bloodshed pollutes the land, and atonement cannot be made for the land on which blood has been shed, except by the blood of the one who shed it. Do not defile the land where you live and where I dwell, for I, the Lord, dwell among the Israelites. ${ }^{160}$ (wording divided for ease of reference and underlining supplied)

The Book of Numbers suggests further legal advancement, viz.

- Cities of Refuge. Six cities of refuge were designated - as opposed to the former three. However, these were of no avail to a person who killed with pre-meditation. No ransom was possible in the case of a murderer, even if he fled to such a city;

- $\quad$ Presumptions of Premeditation. The Book of Deuteronomy referred to:

(a) one who lay in wait for another, assaulted (attacked) him and killed him. The Book of Numbers added where a person:

(b) pushed another or threw something at him intentionally; or

(c) hit him with his fist in 'hostility' (with anger or hatred, as opposed to by error or accident or self-defence); or

(d) struck him with an iron object (sword, spear, knife etc) or with a stone in his hand or with a wooden object. In all these cases, pre-meditation was presumed. ${ }^{161}$

In respect of brawling, (c) and (d) suggest a tightening up of the law. Thus, even where there had been a brawl leading to the killing it seems likely that the circumstances of it were closely analysed to see whether - during the course of it - there had been premeditation by the killer. If so, the death penalty applied;

- $\quad$ Witnesses. This Book stated that no one shall be put to death on the 'testimony of only one witness.'

\section{In conclusion, this was a further clarification of the law.}

\section{(iv) Book of Joshua (c. 625 BC)}

The Book of Joshua (of uncertain date, but after the Book of Numbers), ${ }^{162}$ chapter 20, v 1 onwards, provides:

Then the Lord said to Joshua: Tell the Israelites to designate the cities of refuge, as I instructed you through Moses [see Book of Numbers above], so that anyone who kills a person accidentally and unintentionally ${ }^{163}$ _may flee there and find protection from the avenger of blood.

When he flies to one of these cities, he is to stand in the entrance of the city gate ${ }^{164}$ and state his case before the elders of that city. Then they are to admit him into their city and given him a place to live with them. If the avenger of blood pursues him, they must not surrender the one accused, because [he killed his neighbour unintentionally and without malice aforethought.] ${ }^{165} \mathrm{He}$ is to stay in that city until he has stood trial before the assembly and until the death of the high priest who is serving at that time. Then he may go back to his own home in the town from which he fled.

So they set apart Kedesh in Galilee in the hill country of Napthali, Shechem in the hill country of Ephraim, and Kiriath Arba (that is, Hebron) in the hill country of Judah. On the east side of the Jordan of Jericho they designated Bezer in the desert on the plateau in the tribe of Reuben, Ramoth in Gilead in the tribe of Gad, and Golan in Bashan in the tribe of Manasseh. Any of the Israelites or any alien living among them who killed someone accidentally ${ }^{166}$ could flee to these designated cities and not be killed by the avenger of blood prior to standing trial before the assembly.

In this Book more of the legal process is revealed. A person fleeing to a city of refuge (including a foreigner) must state his case before the elders of the city. He is not to be handed over to the avenger of blood prior to trial. If it was found that the killing was accidental (or negligent or in self defence) or (it seems) as a result of a brawl, he is to be granted sanctuary and to stay in the city until the death of the high priest, when he may return to his home, without the prospect of being

\footnotetext{
160 The NIV, n 6, p 238, states: The idea of providing cities of refuge (Jos 20:1-9) for capital offences is rooted in the tension between customary tribal law (retaliation or revenge in which the blood relative is obligated to execute vengeance) and civil law (carried out less personally by an assembly according to a standard code of justice). Blood feuds are usually associated with nomadic groups; legal procedures, with villages and towns. Israel, a society in the process of settling, found it necessary to adopt an intermediate step regulating manslaughter, so that an innocent person would not be killed before standing trial. Absolution was possible only by being cleared by the assembly of his home town, and by the eventual death of the high priest, which freed the offender from ritual pollution.' See also Phillips, $n$ 103, pp 107-8.

${ }^{161}$ Despite this, one assumes that the killer could provide evidence to the elders that there was no plot to kill and, thus, outweigh the presumption (for example, arguing that he pushed the victim intentionally but only as part of a game etc).

${ }^{162}$ See also NIV, n 6, pp 284-6.

${ }^{163}$ The Hebrew uses the words bisgagah (accident), see n 145, and daat bibli (without premeditation or without knowledge), see n 146. See also Neufeld, n 146, p $1 \&$ n 133.

164 The NIV, n 6, p 314 states, in a note: 'city gate. Traditional place for trials, where the elders sat to hold court'.

165 The King James version, 'because he smote not his neighbour unwittingly, and hated him not beforetime.' The Vulgate, $\mathrm{n} 81$, uses the words 'ignorans' and 'quia ignorans percussit proximum eius nec ante biduum triduumve eius probatur inimicus.'

166 The Hebrew uses the word 'bisgagah', see n 153.
} 


\section{killed in retaliation. ${ }^{167}$}

\section{(b) Justifiable Killing}

The Old Testament - like Babylonian law (see (6)) - imposed the death penalty on a:

- $\quad$ sorcerer (wizard) ${ }^{168}$

- $\quad$ perjurer (i.e. a false witness) ${ }^{169}$

- $\quad$ adulterer caught in flagrante. ${ }^{170}$

The first two were likely treated as examples of pre-meditation. It is not difficult to surmise why:

- The Jews of the Old Testament - like the Babylonians - had a fear of evil spells and believed that a person could die as a result of a spell (curse) being placed on them. Further, sorcerers usually worked with poisons. Thus, if a person died where sorcery was alleged (the victim being cursed or given poisonous herbs) this evidenced premeditation;

- So too, where a person bore false witness against another, so that he (or she) was condemned to death.

In these cases (as well as in the case of adultery) if a person was killed, it was justifiable. No crime had been committed; therefore, the blood feud did not apply. It seems clear it was also justifiable to kill (that is, no blood guilt lay) when:

- $\quad$ pursuant to due legal process; $;^{171}$

- $\quad$ pursuant to lawful revenge (the blood feud); ${ }^{172}$

- $\quad$ an enemy, in a just war (a just war being one sanctioned by God); ${ }^{173}$

- a night thief (burglar). ${ }^{174}$

As will be seen, all these also comprised justifiable killing under Anglo-Saxon law (see 9).

\section{(c) Excusable Killing}

In respect of this:

- It seems there is no provision in the Bible excusing a man from intentional homicide when acting in self defence although it may be the killing of a night burglar was on this basis; ${ }^{175}$

\footnotetext{
${ }^{167}$ One suspects that many persons, in practice, remained in the City since there would always be a risk of being killed in any case if they returned home. ${ }^{168}$ NIV, n 6, Book of Exodus, ch 22, v 18 'Do not allow a sorceress to live.' Book of Leviticus, ch $20 \mathrm{v} 27$ 'A man or woman who is a medium or spiritist among you must be put to death.' Book of Deuteronomy, ch 18, v 10 'Let no one be found among you who...practices divination or sorcery, interprets omens, engages in witchcraft, or casts spells...'. Book of Leviticus, ch 19 v 26 'Do not practise divination or sorcery.'

${ }^{169}$ Ibid, ch 20, v 16 'You shall not give false testimony against your neighbour.' Book of Exodus, ch 23, v 1 'Do not spread false reports. Do not help a wicked man by being a malicious witness'. Ibid, $\mathrm{v} 6$ 'Have nothing to do with a false charge and do not put an innocent or honest person to death for I will not acquit the guilty.' Book of Leviticus, ch 19, v 12 'Do not swear falsely by my name...'. Book of Deuteronomy, ch 5, v 20 'You shall not give false testimony against your neighbour.' Ibid, ch 19, v 18 'if the witness proves to be a liar, giving false testimony against his brother, then do to him as he intended to do to his brother. You must purge the evil from among you. The rest of the people will hear of this and be afraid, and never again will such an evil thing be done among you. Show no pity: life for life, eye for eye, tooth for tooth, hand for hand, foot for foot.' See also Phillips, n 103 , p 96 and Davis, n 5, p 10 (citing another commentator (Finkelstein) that the Pharisees exacted financial compensation as the punishment for a perjurer, unless, as a result of his perjury, capital punishment had been imposed on the accused). See also pp 47, 53. Also, Sulzberger, $\mathrm{n} 98, \mathrm{p} 121$.

${ }^{170}$ The ten commandments included a prohibition against adultery. Book of Exodus, ch 20, v 14 'You shall not commit adultery'. With a suspected adulteress, there was a trial by ordeal - with punishment of death if guilty, at the husband's discretion. Book of Leviticus, ch $20 \mathrm{v} 10$ 'If a man commits adultery with another man's wife...both the adulterer and the adulteress must be put to death.' See also Book of Numbers ch 5, v 11 et seq (test for an unfaithful wife). In particular, adulterers caught in the act (in flagrante) were subject to the death penalty. Book of Deuteronomy, ch 22 , v 22 'If a man is found sleeping with another man's wife, both the man who slept with her and the woman must die.' See also New Testament, John, ch 8, v 3 (woman caught in adultery). Also, Patrick, n 131, p 55, W Jacob \& M Zemer, Crime and Punishment in Jewish Law (1999), p 48 and Phillips, n 103, ch 9.

${ }^{171}$ Sulzberger, $\mathrm{n} 98, \mathrm{p} 34$ 'as such killing is the performance of a public duty, no blame attaches therefor.' Also, p 53, the blood guilt for the execution of the convicted person was on himself (damaw bo).

172 This would occur if the killing was pre-meditated and the killer did not go to a city of refuge. Or, where the elders of the city of refuge adjudged that the killing had been premeditated and handed the killer over to the avenger of blood, for due punishment. So, too, in the case of accidental or negligent or non-premeditated intentional killing, where the killer had failed to flee to a city of refuge. See also Sulzberger, $\mathrm{n}$ 98, $\mathrm{p} 146$ who asserted the blood feud (kofer) for homicide ended in hebrew law by $850 \mathrm{BC}$ when Jehoshapat established federal courts and sheriffs in every canton, with a supreme appellate court in Jerusalem.

${ }^{173}$ Patrick, n 131, p 53 'The prohibition against killing does not rule out participation in war or capital punishment. Killing is authorised by God for serious breaches of divine law and for wars that have divine support... When a person kills as a member of a court, or as the avenger of the blood, or as a member of the army, that person acts as the agent of the One [i.e. God] who has authority over life and death.' See also NIV, n 6, Book of Deuteronomy, ch $20 \mathrm{v} 13$ 'When the lord your God delivers it [the city of your enemy] into your hand, put to the sword all the men in it.' See also Sulzberger, $\mathrm{n} 98, \mathrm{p}$ 29-30 'Blood so shed is called war-blood (deme milhamah)(1 Kings 2.5), and for its shedding no blood guilt (damin) arises either against the individual slayer or against the community.' This did not apply in peacetime. Ibid, $\mathrm{p} 31$.

${ }^{174} \mathrm{NIV}, \mathrm{n} 6$, Book of Exodus ch 22, $\mathrm{v} 2$ 'If a thief is caught breaking in and is struck so that he dies, the defender is not guilty of bloodshed; but if it happens after sunrise, he is guilty of bloodshed.' Hale, $n$ 45, vol 1, p 4 'The killing of a thief in the night was not liable to punishment of death; but if it were in the day-time, it was punishable with death.' Davies, $\mathrm{n} 98, \mathrm{p} 33$ 'This is perfectly natural, for burglars have all the advantage in the darkness of the night; their apprehension is very difficult, and their identification always all but impossible. Moreover, a burglar, in case of an effort to capture him, seldom hesitates to resort to extreme measures.' Phillips, n 103, pp 92-3 thought that 'since the householder would normally have been present in his house at night, the intruder must have taken this into account, and it was therefore reasonable for the householder to presume that the intruder was intent on murder.' See also Barmash, $\mathrm{n}$ 100, $\mathrm{p}$ 124. See also Sulzberger, $\mathrm{n}$ 98, $\mathrm{p}$ 34. Babylonian law appears to have permitted the killing of a thief during the day as well as at night. Cf. Edwards, n 98, p 122.
} 
- However, Hale asserted that - in practice - Jewish custom excused a person from the death penalty when he killed in self-defence. ${ }^{176}$ Further, this (likely) also covered immediate family and kin.

Finally, in the case of an unsolved killing - unlike Babylonian law - it seems that the community did not have to pay a fine. Spiritual atonement was sufficient. ${ }^{177}$

\section{(d) Conclusion}

Old Testament law was similar to Babylonian law in respect of homicide.

- However - as Jewish society moved from a nomadic to a settled community - legal refinements sought to move away from the strict application of the lex talionis and the blood feud. Thus, the Book of Numbers provided more places of sanctuary (six in total) ${ }^{178}$ - as well as the requirement that a killing be judged before an assembly, with more than one witness;

- Also, accidental (and negligent) killing, as well as killing in self defence or in a brawl, was cleansed when the high priest died, so that the killer could return to his town (village) without fear of a blood feud ensuing - although this concession did not avail a person who so killed unless he fled to a city of refuge, ${ }^{179}$

- However, murder (premeditated killing) remained unatonable (that is, not capable of monetary compensation). The death penalty applied without exception.

In conclusion, although the Bible reflected the general principle of the lex talionis (a life for a life), it was an advance on Babylonian law. It introduced a means by which a person who had killed accidentally might flee to a city of refuge and escape the death penalty - if the elders of the city upheld his plea that the killing was accidental. It would seem likely that 'accidental' killing embraced negligent killing as well as killing in self-defence. Premeditated killing, however, was unatonable. The death penalty was always imposed and there was no privilege of sanctuary. In the case of killing in a brawl (quarrel) it seems that compensation was possible.

\section{Roman Law}

It is useful to consider the nature of homicide under Roman law since - although Anglo-Saxon law adopted an approach akin to Old Testament law - Bracton (writing c. 1240) derived various of his propositions from Roman law. Further, as to murder (premeditated killing), Roman law seems to have been the same as Old Testament law even though it was not based on the lex talionis. Under Roman law, it seems that - until a late stage - homicide was dealt with by the male head of the household (the paterfamilias) in respect of his family and slaves. ${ }^{180}$ Thus, Robinson noted:

It seems likely that for the Romans, as in our day, most murders were family affairs and, until well into the Principate $[27 \mathrm{BC}-284 \mathrm{AD}]{ }^{181}$ that these would therefore fall within the jurisdiction of the relevant paterfamilias or owner (or patron). ${ }^{182}$ Of course, when the paterfamilias was the murderer, someone technically outside the familia would need to intervene...

Domestic authority was only slowly eroded; most obviously, the exposure of unwanted infants long remained a proper exercise of patria potestas. Until the late Republic [147-130 BC] and perhaps even into the Empire [27 BC -

\footnotetext{
175 Hale, n 45, vol 1, p 4 'there is no express law touching killing a man in his own defence' In a fn he states: 'This was a case so plainly justifiable by the law of nature, that it needed no positive law; however, the permission to kill a thief, who should be found breaking up in the night, seems to be an express allowance of killing in one's own defence; for the reason of that law is manifestly founded on the principle of self- preservation.'

${ }^{176}$ Ibid, p 4 'yet it seems the custom of the Jews, and the interpretation of the Jewish doctors, excused the fact from the punishment of death.' In a fn Hale stated 'When done in defence of life or charity [likely a reference to protecting others]; because, when lost, they are irreparable.' Hale quoted J Selden, De Jure Naturali et Gentium, Juxta Disciplinam Ebraeorum (1640), bk 4, ch 3. Also Maimonides (Moses ben Maimon, 1135-1204), The Guide of the Perplexed (also called Moreh Nebukhim)(pub. 1190), pt 3, ch 40. Phillips, n 103, p 93 'where death occurred in self defence, no charge would have been brought'. See also Exodus, ch 21, v 13 (see n 128) which Phillips interprets as including self defence, the killing being unintentional. Sulzberger, $\mathrm{n}$ 98, $\mathrm{p}$ 53 'The hebrew law put under one and the same head of manslaughter, the voluntary, the involuntary, and the excusable homicide of our common law. They recognized an element of supernatural influence in them all equally, and punished them alike.'

${ }^{177}$ NIV, n 6, Book of Deuteronomy, ch 21, vv 1-9 (the elders of the town nearest the body were to slaughter a heifer by way of atonement). Phillips, $\mathrm{n}$ 103, p 94 'The responsibility for effecting this was placed on the town nearest to which the murdered man's corpse was found.' See also Daube, $\mathrm{n} 118$, ch 4 (communal responsibility).

${ }^{178}$ Jacob \& Zemer, n 170, p 47 'Murder was differentiated from accidental killing, and so were the punishments. The cities of refuge provided a safe haven for the innocent, although we know nothing about the way in which they functioned, and they were not replicated in any form in later Jewish history. Murder was severely punished through the death penalty, which was carried out by the courts or by the relatives of the victim...' See also Phillips, $\mathrm{n}$ 103, p 99 et seq. It may be noted that, generally, the lex talionis moved towards financial compensation in most instances. Davis, n 5, p 3 'In the second century AD and later, Jewish rabbinic leadership was essentially unified that the OT [Old Testament] did not require a literal talion but that financial penalties could be substituted in court matters.' See Ibid, p 5.

${ }^{179}$ Hale, $\mathrm{n} 45$, vol 1, pp 3-4 'the killing of a man by misfortune was not liable to the punishment of death, by the sentence of the judge; but yet the avenger of blood might kill him, before he got to a city of refuge.'

${ }^{180}$ OF Robinson, The Criminal Law of Ancient Rome (John Hopkins University Press, 1955), p 41 noted, generally: 'The treatment of crimes of violence, crimes against the person other than sexual offences, was relatively sparse in Roman law.'

${ }^{181}$ The Principate comprised the first period in the Roman Empire, being from 27 BC - 284 AD.

${ }^{182}$ See also A Watson (ed), The Digest of Justinian (University of Pennsylvania Press, 1985), vol 4, bk 48.1.1 where the Roman jurist Macer - in his text on Criminal Proceedings - noted that not all trials were public criminal ones but only those which arose from statutes on criminal proceedings, such as the lex Julia on treason, the lex Julia on adultery, the lex Cornelia on murderers and poisoners, the lex Pompeia on parricide, the lex Julia on embezzlement, the lex Cornelia on wills, the lex Juliae on vis privata and vis publica, the lex Julia on electoral corruption, the lex Julia on extortion, and the lex Julia on the corn dole. Macer worked during the reign of the emperor Severus (222-35 AD). Justinian (483-565) Byzantine emperor from 527-65, ordered the codification of Roman law (Corpus Juris Civilis) of which the Digest formed part.
} 
$76 \mathrm{AD}],{ }^{183}$ it is probable that, for an ordinary murder not within one household, the victim's family was able to use a private criminal action to obtain the surrender to them of the murderer - or sometimes they may have been satisfied that the head of the perpetrator's household would take suitable steps to punish the offender by his domestic authority. This survival of domestic jurisdiction helps to explain why the focus of the crime in the ordo iudicorum publicorum was on public order. ${ }^{184}$ (wording divided for ease of reference)

\section{(a) Twelve Tables (c. 449 BC)}

The Twelve Tables (promulgated c. 449 BC) are said to comprise the oldest Roman criminal law. What they actually stated is unclear. However, they have been re-constituted. ${ }^{185}$ In respect of homicide it is said that the Twelve Tables provided that:

whoever knowingly [sciens] and maliciously [dolo] kills a free man must be put to death. Let him who uses wicked enchantments, or makes or gives poisons, be deemed a parricide. ${ }^{186}$ (underlining supplied)

The reference to 'knowingly and maliciously' covers pre-meditation. As with the Old Testament (see 7), poisoning and witchcraft were closely associated and it was justifiable to put such persons to death. ${ }^{187}$ The Twelve Tables also provided that it was justifiable to put to death the following, a:

- $\quad$ night thief (burglar) ${ }^{188}$

- thief taken during the day who resisted with weapons; ${ }^{189}$

- perjurer. $^{190}$

\section{(b) Lex Cornelia (81 BC)}

The Lex Cornelia $(81 \mathrm{BC}){ }^{191}$ dealt with: poisoning, gangsters, ${ }^{192}$ giving (or procuring) false witness (i.e. perjury) and accepting a bribe for a verdict which brought about the death of someone. ${ }^{193}$ The Roman jurist Paul ${ }^{194}$ summarised the content of this law:

The lex Cornelia inflicts the penalty of deportation on anyone who kills a man or carries a weapon for theftuous purposes, and on anyone who possesses, sells, or prepares poison for the purpose of killing a man, or who gives false witness whereby someone dies or death is brought about. .. A murderer is someone who kills a man with any sort of weapon or brings about a death. ${ }^{195}$

Robinson noted that - although public order was the background to the Lex Cornelia - it did (or soon came to) cover ordinary murder. And not only murder on the public highway but also in private houses. Also, death inflicted in a brawl or arising from going about armed with murder in mind. ${ }^{196}$ As to intention, Robinson noted that:

\footnotetext{
${ }^{183}$ The late republic was from 147-30 BC. The Roman Empire was from $27 \mathrm{BC}$ (under the emperor Augustus) until its fall in the West in $476 \mathrm{AD}$.

${ }^{184}$ Robinson, n 180, pp 41-2.

${ }^{185}$ See Stephen, $\mathrm{n} 55$, vol 1, ch 2 .
}

${ }^{186}$ Ibid, p 11. Stephen took this from RJ Pothier, Pandectae Justinianeae (Justinian's Pandects, Paris 1818), p xciv 'Si qui hominem liberum dolo sciens morti duit.' The Twelve Tables is also said to have stated: 'If a man kills his parent, veil his head, sew him up in a sack, and throw him into the river.' In the case of a thief caught in the act, the Twelve Tables is said to have provided 'A thief taken in the fact (fur manifestus) must be beaten with rods, and adjudged (as a slave) to the person robbed. If a slave he must be beaten with rods and thrown from the Tarpeian rock... A thief discovered by plate and girdle [i.e. with the stolen goods on him] is to be deemed to be taken in the fact.' See Stephen, n 55, pp 10-1. See also F de Zulueta, The Institutes of Gaius (Oxford, 1946), p 217 (with plate and licium, by a searcher who checked whether a person had stolen goods on him. Under the Twelve Tables, theft was a capital offence). As for poisoning, this was a frequent fear and occurrence in Rome, see Robinson, p 180, ns 11 \& 30. Also, p 42 (special courts were established).

${ }^{187}$ Ibid, p 19 'Poisoning is naturally an object of excessive dread in an age in which physical science is at a low ebb, and when belief in witchcraft and other 'maleficia' prevails.'

${ }^{188}$ Ibid, p 10 'If a man is killed whilst committing theft by night he is lawfully killed. If a thief is taken by day he may not be killed unless he resists with a weapon.' AW Lintott, Violence in Republican Rome (Oxford, 1968), p 13 'The clause suggests that if the thief came by night or used a weapon the proper course was to draw attention and gather supporters by shouts: then, if he was not killed in the struggle to seize him, it would be possible to execute the thief after a hearing before a council of neighbours.'

${ }^{189}$ Ibid 'If a thief is taken by day he may not be killed unless he resists with a weapon.' See also Stephen, n 55, vol 1, p 28.

${ }^{190}$ Stephen, n 55, vol 1, p 11 'Whoever gives false evidence must be thrown from the Tarpeian rock.' The latter was a cliff of some 80 feet off the southern summit of the Capitoline Hill, overlooking the Roman Forum. For later Roman law see Digest, n 182, bk 48.8.1 which quoted Marcian who, in his Institutes, bk 14 stated that the Lex Cornelia covered one who 'with malicious intent gives false evidence so that someone may be condemned in criminal proceedings for a capital offence.' The Roman jurist Aelius Marcianus wrote after the death of the emperor Septimus Severus (emperor from 193-211 AD). His Institutiones comprised 16 books.

${ }^{191}$ The full title of this legislation was the Lex Cornelia de Sicariis et Veneficiis (Lex Cornelia on Gangsters and Poisoners). Roman law also made special provision for the killing of a parent (parricide) in the Lex Pompeia de Parricidiis (52 BC). Parricide was later reflected in the English crime of petty treason (because the murder was of someone to whom a special allegiance was owed). This is not considered further, since petty treason was abolished in 1828 (9 Geo 4 c 31 s 52). See also Stephen, n 55, vol 1, pp 17-8, 19-20.

${ }^{192}$ Robinson, n 180, p 42 'Sicarius (homicida as a word for murderer was not much used in the legal sources until the time of Constantine [Roman emperor 306-337 AD]) meant a knife man or gangster; the term indicates that the crime was seen more as an offence against public order than against the life or limb of the individual victim.'

${ }^{193}$ Ibid. pp 41-2.

${ }^{194}$ Julius Paulus Prudentissimus (fl $2^{\text {nd }}$ and $3^{\text {rd }} \mathrm{c}$ AD). He was a member of the imperial council, the praetorian prefect of the praetorian guard, a contemporary of Ulpian ((c. 170-223, a famous Roman jurist) and one of five Roman jurists whose work was made constitutionally authoritative by the emperors Theodosius II (Eastern Roman emperor from 408-50 AD) and Valentinian III (Western Roman emperor from 425-55 AD).

${ }^{195}$ Robinson, n 180, p 43. There was another statute on murder, the Lex Clodia (59 BC) which dealt with murder arising from abuse of office. Ibid. 196 Ibid. 
An intention to kill was necessary, and it was this intention which made someone who ordered a killing a murderer $;{ }^{197}$ an infant or madman could not be liable since they could not form a murderous intention. ${ }^{198}$ The motive was irrelevant; a mercy killing would still have counted as murder. An absence of premeditation might reduce the liability. ${ }^{199}$ If a killer lacked intention to kill there should be acquittal from the charge of murder, but wounding with intent to kill might be sufficient to found homicide. Hadrian wrote that... 'in crimes it is the intention, not the issue to which regard is paid. ${ }^{200}$ Guilty intention could be presumed from the deed, which need not be direct, for furnishing the cause of death was expressly provided for, ${ }^{201}$ but gross carelessness did not amount to the mens rea for murder. ${ }^{202}$

The reference to the emperor Hadrian is to a rescript (written reply) of the same. As to its content, in the Digest of Justinian, ${ }^{203}$ the Roman jurist, Marcian ${ }^{204}$ - in his legal text, the Institutes, book 14 - stated:

The deified Hadrian [emperor from 117-138 AD] wrote in a rescript that he who kills a man, if he committed this act without the intention of causing death, could be acquitted; and he who did not kill a man but wounded him with the intention of killing ought to be found guilty of homicide.

On this account, it should be laid down that if someone draws his sword or strikes with a weapon, he undoubtedly did so with the intention of causing death; but if he struck someone with a key or saucepan in the course of a brawl, although he strikes [the blow] with iron, yet it was not with the intention of killing. From this it is to be deduced that he who has killed a man in a brawl by accident rather than design should suffer a lighter penalty. ${ }^{205}$ [i.e. presumption of intention or lack of]

Again, the deified Hadrian wrote in a rescript that he who kills someone forcibly making a sexual assault on him or a member of his family should be discharged. [i.e. a defence to homicide].

The deified Pius ${ }^{206}$ wrote that a lighter penalty should be imposed on him who killed his wife caught in adultery, and ordered that a person of low rank should be exiled permanently, but that one of any standing should be relegated for a set period. ${ }^{207}$ [i.e. provocation] (wording divided for ease of reference)

In conclusion, under Roman law, accidentally or negligently killing a person was not murder but intentionally killing was. The latter was presumed where a person used a weapon. Further, a person who only wounded another but intended to kill him, was guilty of murder.

\section{(c) Defences}

Robinson noted that it was justifiable under Roman law to kill in self-defence. Also, to kill an adulteress caught in flagrante. He stated:

killing in self-defence, including defence of a member of one's family against a sexual assault, was justifiable homicide, although under Justinian and possibly earlier the Romans accepted the doctrine of minimum force - if and only if the killer could not have spared the man's life without risk to his own.

Certain other killings, such as by a paterfamilias of a filia [daughter] caught in the act of adultery in the pater's house, might be viewed as justifiable homicide... ${ }^{208}$ Vengeance, however, was murder from early in Roman law;

\footnotetext{
197 Ibid.

${ }^{198}$ Ibid, p 44 referred to the Digest, n 182, bk 48.8.12 which quoted Modestinus who in his Rules, book 8 stated 'An infant or madman who kills a man is not liable under the Lex Cornelia, the one being protected by the innocence of his intent, the other excused by the misfortune of his condition.' Herennius Modestinus, a member of the imperial council and a student of Ulpian (see n 194), flourished c. 250 AD.

199 Robinson referred to the Digest, n 182, bk 48.5.39.8 (killing a wife caught in the act of adultery).

${ }^{200}$ Ibid, n 182, bk 48.8.14 in which the Roman jurist Callistratus, in his Judicial Examinations, book 6 stated 'The deified Hadrian wrote a rescript in the following words: 'In crimes it is the intention, not the issue, to which regard is paid.' Hadrian was emperor from 117-138 AD. A rescript was a written explanation issued by a Roman emperor in reply to an appeal for guidance (including on legal matters) which was usually sought by an official. Callistratus was a Roman jurist who wrote in the reigns of the emperors Septimius Severus (193-211 AD) and Caracalla (198-217 AD).

${ }^{201}$ Robinson referred to the Digest, n 182, bk 48.8.15. It quoted the Roman jurist Ulpian (see n 194) who, in his Lex Julia et Papia, book 8 stated: 'It makes no difference whether someone kills or provides the occasion of death.'

${ }^{202}$ Ibid, n 182, bk 48.8.7. It quoted the Roman jurist Paul (see n 194) who, in his text on Criminal Proceedings, stated: 'Under the lex Cornelia, guilty intention is presumed from the deed. But, under this law [the Lex Cornelia], gross negligence is not interpreted as guilty intention. Accordingly, if someone throws himself from a height and lands on another, killing him, or a pruner when throwing down a branch from a tree fails to shout a warning and kills a passer-by, punishment under this statute is not applicable.' See also Hale, n 45, vol, p 6 who noted that such a person would be liable, however, for damages under the Lex Aquila. See also Digest, n 182, bk 9.2.31, quoting Paul, Sabinus, bk 10 'If a pruner threw a branch from a tree and killed a slave passing underneath (the same applies to a man working on a scaffold), he is liable only if it falls down in a public place and he failed to shout a warning so that the accident could have been avoided.' There was a Praetorian Edict on this. Ibid Digest, bk 9.3.1, quoting Ulpian's, Edict, bk 23 'The praetor says the following about those who pour out or throw out anything 'If anything should be thrown out or poured out from a building onto a place where people commonly pass and repass or stand about, I will grant an action to be brought against whoever lives there for double the damage caused or done as a result. If it is alleged that a free man was killed by whatever fell, I will grant an action for fifty aurei.' Ibid, 9.3.6, Paul, Edict, bk 19 'This edict applies not only to cities and villages but also to any roads where people commonly pass.'

${ }^{203}$ See n 182.

204 See $n 190$.

205 This reflects Babylonian law and Old Testament (see 6 \& 7).

${ }^{206}$ Pius Antoninus was Roman emperor from 138-161 AD.

${ }^{207}$ See also Robinson, n 180, p 45 which referred to the Digest, n 182, bk 48.8.1.5.

${ }^{208}$ Robinson, n 180, pp 45-6. See also Digest, n 182, bk 48.5 (Lex Julia on punishing Adulteries). See also Stephen, n 55, vol 1, pp 15-6.
} 
vendettas seem never to have been approved. ${ }^{209}$ (wording divided for ease of reference)

Under Roman law, it was also justifiable for a person to kill a:

- $\quad$ highway robber (brigand, bandit) ${ }^{210}$

- night thief; ${ }^{211}$

- thief/robber who attacked, if the victim was put in fear of death. ${ }^{212}$

In these cases, the essential justification was that of self defence.

\section{(d) Conclusion}

The Roman law on murder influenced Bracton (writing c. 1240) and later English law. However, unlike Babylonian, Old Testament and, later, Anglo-Saxon law, Roman law was not based on the lex talionis and the blood feud. Also, unlike these laws, later Roman law (cf. the Twelve Tables) laid no especial stress on premeditated killing, whether for the purpose of sanctuary or otherwise. ${ }^{213}$ In particular, Roman law provided that:

- $\quad$ One who killed another intentionally, committed murder. But one who killed another accidentally or negligently did not commit murder. Intentional killing was presumed where a weapon was used;

- It was not homicide where a person killed another in a brawl, not being treated as intentional, unless a weapon was used;

- It was justifiable to kill:

$\circ$ in self-defence;

○ in defence of family members - including a person sexually assaulting oneself or a family member; ${ }^{214}$

- an adulterer, in flagrante. Thus, a father (or husband) could kill the lover of his daughter (wife) caught in the act. The basis was, effectively, provocation;

- a highway robber (brigand, bandit);

- a night thief;

- a thief (or robber) who attacked one, if one was put in fear of death.

In conclusion, Roman law was an advance on Old Testament law - in that it did not recognise the lex talionis or the blood feud. It treated murder as killing with an intention to kill (which was presumed when a weapon was used) or where a person wounded another with intent to kill, but did not kill him.

\section{Anglo-Saxon Law}

\section{(a) Homicide}

A previous article has considered Anglo-Saxon law. ${ }^{215}$ In particular:

- Anglo-Saxon law made no clear division between criminal - and civil - law;

\footnotetext{
${ }^{209}$ Robinson, n 180, p 45. See also Stephen, n 55, vol 1, pp 15-6.

${ }^{210}$ Digest, n 182, bk 9.4 quotes the Roman jurist Gaius who, in his Provincial Edict, bk 7 stated: 'if I kill your slave who is lying in ambush to rob me, I shall go free; for natural reason permits a person to defend himself against danger.' See also Hale, n 45, vol 1, p 6.

${ }^{211}$ See n 188. See also Digest, n 182, bk 9.4 in which the Roman jurist Gaius, in his Provincial Edict, bk 7 stated: ' 1 . The law of the Twelve Tables permits one to kill a thief caught in the night, provided one gives evidence of the fact by shouting aloud, but someone may only kill a person caught in such circumstances at any other time if he defends himself with a weapon, though only if he provides evidence by shouting.' Commenting on this, as to why the killing of a night thief was justifiable, Hale, n 45, vol 1, p 6 cited H Grotius, The Rights of War and Peace (Liberty Fund, 2005), vol 2, p 410 'in the night it is not an easy matter to have witnesses; and therefore, if the thief should be found dead, we readily give credit to a person who declares that he slew him in his own defence, since he was armed with some dangerous instrument'. For later Roman law, see Digest, n 182, bk 48.8.9 which quoted Ulpian's Edict, book 37, 'If anyone kills a thief by night, he shall do so unpunished if and only if he could not have spared the man['s life] without risk to his own.'

${ }^{212}$ Digest, n 182, bk 9.5 quoting Ulpian's Edict, bk 18 'If someone kills anyone else who is trying to go for him with a sword, he will not be deemed to have killed unlawfully; and if for fear of death someone kills a thief, there is no doubt that he will not be liable under the Lex Aquila. But if, although he could have arrested him, he preferred to kill him, the better opinion is that he should be deemed to have acted unlawfully (injuria), and therefore he will also be liable under the Lex Cornelia.'

213 As to the development of sanctuary: (a) the Romans recognized a right of sanctuary and, probably, the use of churches for such (as opposed to temples) came into existence from the time of Constantine's Edict of Toleration (303 AD); (b) the Constitutions of Theodosius the Younger (450 AD) extended sanctuary beyond the walls of the church to the walls of the churchyard or precincts (including the houses of bishops and clergy, cloisters, courts and cemeteries); (c) the Council of Orange (441 AD) ordered that no fugitive seeking sanctuary should be surrendered; (d) the later canon law of Gratian, and papal decretals, granted protection to all criminals apart from night robbers, highway robbers and those guilty of crimes in churches. It is probable that sanctuary applied in later Roman Britain. See generally, NM Trenholme, The Right of Sanctuary in England (1903) University of Missouri Studies, vol 1, no 5. At p 3 he cites Plutarch, Romulus, that as soon as the foundation of Rome was laid a place of refuge was established which they called the temple of the Asylaen God and that murderers could seek refuge there. However, that the right of murderers to sanctuary was excluded by Justinian (see Justinian, Novels (Novellae), bk 17, c 7). See also JC Cox, The Sanctuaries and Sanctuary Seekers of Medieval England (London, 1911).

${ }^{214}$ See (c) above. The Lex Julia on Vis Publica imposed a criminal penalty on a person who forcibly violated (raped) a boy or a woman (single or married) or any other person. See Digest, n 182, bk 48.6.3 \& 48.6.5 (referring to Marcian (see n 190), Institutes, bk 14).

${ }^{215}$ GS McBain, Modernising the Common Law Offences of Assault and Battery (2015) International Law Research, vol 4, no 1, pp 39-155. It may be noted that the writings of Coke, Hale and Stephen on Anglo-Saxon law were scanty and prior to modern translations. For example, Stephen only had Thorpe and not the later (and better) translations of Attenborough and Robertson, see $\mathrm{n} 18$. For a useful modern analysis see generally Hudson, $\mathrm{n} 18$.
} 
- Unlike Roman law - which had no concept of the blood feud - but like Babylonian and Old Testament law, Anglo-Saxon law did. More particularly, Anglo-Saxon Anglo law embraced a 'tariff' system of fines which were imposed on the killer to obviate such a feud. ${ }^{216}$

Indeed, Anglo-Saxon law reflects much of the Old Testament and little of Roman law. This is understandable since it was likely composed - to a great extent - by Christian clerics who also acted as advisers to Anglo-Saxon kings. ${ }^{217}$ In respect of Anglo-Saxon law, the following may be noted in particular:

- The tariff system established the amount of compensation to be paid for killing (slaying) a person. ${ }^{218}$ The compensation was composed of a payment to the family of the victim (bot) as well as a fine paid to the king (wite);

- Compensation was calculated according to the value (worth) of the victim (his wergeld). Further, the quantum reflected two things in particular: (a) the status of the victim; ${ }^{219}$ and (b) where the killing took place. See App A.

As might be expected in Anglo-Saxon England - where illiteracy was high and the law tended to be dispensed orally - both the concept of homicide and the tariff imposed were relatively simple, so that they could be declared by the asega (the 'law speaker') who advised the court. The tariff in respect of homicide applied from the earliest known written Anglo-Saxon law the Code of Aethelbert, king of Kent (c. 558-616) ${ }^{220}$ which was likely issued between AD 597-616 - up to the Norman Conquest of 1066. Indeed, up to the Laws of Henry I (c. 1113), at least (see 10). Prior to analysing the law in detail, the following points may be noted:

- Compensation Payable unless Unatonable. The Anglo-Saxon tariff paid no attention as to why a person killed another. Compensation was, therefore, payable regardless of whether the killing was accidental or intentional. ${ }^{221}$ The exception was where the killing was premeditated. Here, the death penalty applied and the payment of compensation was not possible. ${ }^{222}$ This reflected the Old Testament position;

- Brawls. As with Old Testament law, under Anglo-Saxon law, where the killing was intentional but not premeditated, compensation could be paid. Likely, this reflected the violent nature of the Anglo-Saxons who were warlike and quick to take umbrage. ${ }^{223}$ If killing others in brawls etc was held unatonable, valuable manpower would be lost; 224

- Bi-furcation of Intentional Killing. As with Old Testament (and Babylonian) law, Anglo-Saxon law bi-furcated intentional killing into premeditated and unpremeditated, the latter to deal with brawls;

- $\quad$ Accidental Killing. This included negligent killing (although later Anglo-Saxon law made one or two separate statements on negligent killing) as well as killing in self-defence.

In respect of the categorisation of killing in Anglo-Saxon law, accidental killing will be considered first.

\section{(b) Accidental (\& Negligent) Killing}

Under Anglo-Saxon law, accidental killing required the payment of compensation according to the tariff. ${ }^{225}$ It was the same as Old Testament law in reflecting the lex talionis, repayment in kind by way of financial compensation. Indeed, Anglo-Saxon laws often made direct reference to Old Testament law. Thus, the Introduction to the laws of king Alfred (king of Wessex, 871-99) referred to the Book of Exodus (see 7(a)(i)). This Anglo-Saxon law (probably issued c. 892) stated:

Let the man who slays another wilfully perish by death. [cf. Book of Exodus, ch 21, v 12]

Let him who slays another out of necessity or unwillingly or unwilfully, as God may have sent him into this hands,

\footnotetext{
${ }^{216}$ P \& M, n 88,vol 1, p 47 'Composition must generally be accepted if offered; private war [i.e. the blood feud] is lawful only when the adversary obstinately refuses to do right.' See also Ibid, vol 2, pp 450-1. Composition among the German people existed at least as early as Tacitus, who mentions it, $\mathrm{n} 8, \mathrm{p} 111$ 'The man who is found guilty is fined so and so many horses or cattle. Part of the fine is paid to the king or State, and part to the injured man or his relatives. In the same councils are elected the chiefs, who dispense justice through the country districts and villages.' See also J Goebel, Felony and Misdemeanor (1976), p 21.

${ }^{217}$ McNeill \& HM Gamer, Medieval Handbooks of Penance (Octagon Books, 1965), pp 383-4 'The codes of the various kings were generally framed under ecclesiastical influence, frequently with the advice of bishops and clergy assembled in council.' Anglo-Saxon crimes were also treated as sins, and, thus, there is a close relationship between them and the penances prescribed in various Anglo-Saxon penitentials.

${ }^{218}$ The Anglo-Saxon word usually used was 'ofslean'. JRC Hall, Concise Anglo-Saxon Dictionary (4 ${ }^{\text {th }}$ ed, 1975)( ofslean) 'to strike off or out, cut off, destroy, strike down, kill.'

${ }^{219}$ For the importance of status generally, see Hudson, n 18, ch 8 (status).

${ }^{220} \mathrm{P} \& \mathrm{M}, \mathrm{n} 88$, vol 1, p 27 'We have in the first place the considerable series of laws and ordinances of Saxon and English princes, beginning with those of Aethelbert of Kent, well known to general history as Augustine's convert, which are of about the end of the sixth century.' See also P \& M, vol 2, pp 451-2.

221 TFT Plucknett, A Concise History of the Common Law $\left(5^{\text {th }}\right.$ ed, 1956), p 444 'Murder is the product of many different lines of development. Slaying wilfully or accidentally had the same consequences in Anglo-Saxon law - the offender must bear the feud, or else he must provide the sum of money amounting to the dead man's wer.' J Reeves, History of the English Law ( $2^{\text {nd }}$ ed, 1787, rep Rothmans, 1969), vol 1, p 17 'It does not appear that they made any distinction in the degrees of homicide...'. P \& M, n 88, vol 1, p 52 'Homicide appears in the Anglo-Saxon dooms as a matter for composition in the ordinary case of slaying in open quarrel.' Tacitus, n 8, p 118 'Even homicide can be atoned for by a fixed number of cattle or sheep, and the satisfaction is received by the whole family. This is much to the advantage of the community, for private feuds are peculiarly dangerous side by side with liberty.'

${ }^{222} \mathrm{P} \& \mathrm{M}, \mathrm{n} 88$, vol 1, pp 52-3 'The offence of ['morth'] was unatonable, and the murderer, if ascertained, might be delivered over to the dead man's kindred.'

${ }^{223}$ See $\mathrm{n}$ 8. Goebel, n 216, commenting on early German law (from which Anglo-Saxon derived), put it, p 85 'The law recognizes the heat of rage as it still does today. But it insists in no slowing of the tempo'.

224 See $n 7$.

${ }^{225}$ It would only result in the death penalty if the kin of the man killed refused compensation.
} 
and for whom he has not lain in wait, be worthy of this life and of making lawful compensation, if he seeks sanctuary. [cf. Book of Exodus, ch 21, v 13]

If, however, anyone presumptuously and wilfully slay his neighbour through guile, pluck him from my altar, so that he may perish by death. ${ }^{226}$ [cf. Book of Exodus, ch 21, v 14] (wordin underlined)

Thus, it was premeditated killing (wilfully) where:

- the death penalty was lawfully imposed ('out of necessity'); or

- $\quad$ one killed in self defence ('unwillingly' and, possibly, 'out of necessity'); or

- $\quad$ one killed accidently or negligently ${ }^{227}$ or in a brawl ('unwilfully').

A person who killed accidentally was entitled to sanctuary. ${ }^{228}$ Further, later law (at least) suggests that care was taken in judging whether a killing was intentional or accidental. ${ }^{229}$ In conclusion, as in Old Testament law, under Anglo-Saxon law, accidental (and negligent) killing was atonable and the
death penalty was not applied, unless the kin of the person killed refused to accept compensation.

\section{(c) Intentional Killing - Premeditated}

The Old Testament treated premeditated killing as unatonable. These same propositions are found in Anglo-Saxon law. Thus, the law of Aethelred (issued c. 1008 AD) - which appears to have closely followed the earlier law of Edward and Guthrum (issued post $921 \mathrm{AD}){ }^{230}$ - stated:

if wizards or sorcerers, magicians or prostitutes, those who secretly compass death [morowyrhtan] or perjurers ${ }^{231}$ be met with anywhere in the land, they shall be zealously driven from this land [i.e. exiled] and the nation shall be purified; ${ }^{232}$ otherwise they shall be utterly destroyed in the land, unless they cease from their wickedness and make amends to the utmost of their ability. ${ }^{233}$ (underlining supplied)

This 'secret compassing of death' (morth) was a crime for which no compensation was payable: the death penalty applied. ${ }^{234}$ In this, Anglo-Saxon law reflected early Germanic law from which it derived. Maitland stated:

[morth] occurs in several of the German folk laws or leges barbarorum ${ }^{235}$ and seemingly always points to some attempt at concealment, more especially to the hiding away of the dead man's body. ${ }^{26}$ In England, before the Conquest, it apparently bore a slightly different shade of meaning. It stood for manslaughter by poisoning, witchcraft or other diabolic practice, and such morth was punished as a true crime in days when mere deliberate

${ }^{226}$ This Introduction is contained in Thorpe, n 18, p 20 et seq, but not in Attenborough (n 18, p 35). See also Hudson, n 18, pp 169, 183 and Stephen, n 55, vol 1, p 24. Also, F Liebermann, King Alfred and the Mosaic Law, Jewish Historical Society of England (Paper read on 3 February, 1908) who stated, p 22 'About the year 890 there probably was no soul living in Britain that knew Hebrew' which accounts for the some of the errors in the redaction of the Bible into Alfred's law.

227 Attenborough, n 18, p 79, (Laws of Alfred, 871-99) 'if a man has a spear over his shoulder, and anyone is transfixed thereon, he shall pay the wergild without the fine. If [the man] is transfixed before his eyes, he shall pay the wergild; and if he is accused of deliberate intention in the act, he shall clear himself with an oath equal to the fine, and thereby dismiss the claim for the fine. Supposing the point to be higher than the [other] end of the shaft, by the width of three fingers. If they are both on a level, the point and the [other] end of the shaft, the man with the spear shall not be regarded as responsible for causing danger [i.e. negligent].' See also P \& M, n 88, vol 1, pp 54 'the question of negligence is not considered at all.'

${ }^{228}$ See also Attenborough, n 18, p 39, (Laws of Ine, 688-725) 'If anyone is liable to the death penalty, and he flees to a church, his life shall be spared and he shall pay such compensation as he is directed [to pay] by legal decision.'

${ }^{229}$ Robertson, n 18, p 107, (Laws of Athelred, 865-71) 'Careful discrimination shall be made in judging every deed, and the judgment shall always be ordered with justice, according to the nature of the deed, and meted out in proportion, in affairs both religious and secular; and, through the fear of God, mercy and leniency and some measure of forbearance shall be shown towards those who have need of them'.

${ }^{230}$ See Attenborough, n 18, p 109.

231 Whether perjury in a capital case was, ipso facto, punishable with death is unclear. See also Attenborough, n 18 , p 117 (Laws of Edward the Elder, 899-924) if the charge of perjury was proved, never again 'shall they have the privilege of clearing themselves by oath, but only by the ordeal'. Ibid, $\mathrm{p}$ 141 (Laws of Aethelstan, 924-39) 'never again the right to swear an oath.' For later Anglo-Saxon law, see Robertson, n 18, pp 7,25, 87,89,101, 103, 145, $179,183,195$ (if a man swore a false oath on the relics, to lose his hand).

${ }^{232}$ See also Robertson, n 18, p 177, (Laws of Canute, 1016-35) 'We earnestly forbid all heathen practices. Namely, the worship of idols...or the compassing of death in any way, either by sacrifice or by divination or by the practice of any such delusions.' See also O'Brien, $\mathrm{n} 19$, $\mathrm{p} 344$ 'murderers are grouped most often with wiccan 'wizards, witches' and mansworan 'perjurers' as well as forlegenan 'adulterers' and peofas 'thieves', not because all of these criminals are linked to witchcraft, but rather because they all appear in the Decalogue's list of criminals, which includes colentes deos alienos 'worshippers of strange gods', occisores 'killers', moechi 'adulterers', fures 'thieves', and those who bear falsum testimonium 'false witness'.'

${ }^{233}$ Ibid, p 93. See also p 87. Ibid, p 101 'And deceitful deeds and hateful injustices shall be strictly avoided, namely...devilish deeds such as murders and homicides...' This law of Aethelred (c. 1008) was repeated in the Laws of Canute (issued c. 1020), p 177 'If wizards or sorcerers, those who secretly compass death, or prostitutes be met with anywhere in the land, they shall be zealously driven out of this land or utterly destroyed in the land, unless they cease from their wickedness and make amends to the utmost of their ability.' Ibid, p 145 'And likewise they [the bishops] teach us further that... we should...put away from us every form of unrighteousness, such as [the deeds of] parricides, murderers, perjurers, witches, sorceresses and adulterers, and incestuous deeds.' See also Attenborough, n 18, p 131 (Laws of Athelstan, 924-39) 'we have declared with regard to witchcrafts and sorceries and deadly spells, if death is occasioned thereby, and [the accused] cannot deny it [the charge], that he shall forfeit his life.' Also, Hudson, $\mathrm{n} 18$, $\mathrm{p}$ 167. Libermann, n 226, p 26 'Capital punishment for sorcery occurs in Anglo-Saxon law only where the murder was connected with it.'

${ }^{234}$ See Robertson, n 18, p 207, (Laws of Canute, 1016-35) '...murder which cannot be denied... [is a crime] for which no compensation can be paid.'

${ }^{235}$ For the various Germanic laws, see GS McBain, Modernising of the Law: Breaches of the Peace and Justices of the Peace Journal of Politics and Law (2015), vol 8, no 3, s 2. O'Brien, n 19 (article), pp 351-2 'the Lex Baivariorum elaborates that if someone killed a freeman in a furtive way and tried to dispose of the body, this would be called murdrida by the Bavarians.' He noted other early Germanic laws did the same.

${ }^{236}$ See also P \& M, n 88, vol 2, p 486. 
manslaughter was hardly a crime at all in our sense of the word. ${ }^{237}$

Pollock \& Maitland also stated:

Homicide appears in the Anglo-Saxon dooms as a matter for composition in the ordinary sense of slaying in open quarrel. ${ }^{238} \ldots$. We find a rudiment of the modern distinction between murder and manslaughter, but the line is drawn not between wilful and other killing but between killing openly and in secret. It would seem indeed that 'moro' [morth] at one time meant only killing by poison or witchcraft. The offence of 'moro' was unatonable, and the murderer, if ascertained, might be delivered over to the dead man's kindred. ${ }^{239}$

One would agree with these authors on this, save that Maitland did not analyse Old Testament law in detail and some additional comments can be made:

- Babylonian law, Old Testament law, early Germanic law and Anglo-Saxon law were all the same in distinguishing between premeditated and unpremeditated killing. The former was 'secret' being plotted - and there was a presumption (evidence) of premeditated killing when a person was killed by: (a) witchcraft; (b) poison; ${ }^{240}$ (c) in an ambush or not in the open; (d) where the body was subsequently concealed; (e) where it could be shown the killer harboured a prior 'grudge' or 'hatred' (malice) against the victim. Thus, 'morth' (secret killing) was the same as a reference to premeditated killing;

- Anglo-Saxon penitentials, which Maitland did not analyse, clearly show this distinction ${ }^{241}$ in which premeditated killing deserved a more severe penance. Further, premeditation, clearly, was the same as the term 'malice aforethought'. 242

\section{In conclusion - like Old Testament law - under Anglo-Saxon law, premeditated killing was unatonable. The death penalty} applied.

\section{(d) Intentional Killing - Unpremeditated}

If there was no pre-meditation, compensation was sufficient in the case of intentional killing, provided the kin of the person killed were prepared to accept it. The latter was important since the basic principle of Anglo-Saxon law was the same as that of the Old Testament - life for life. As to sanctuary, this likely was introduced by the church into Anglo-Saxon law from an early date:

- The laws of Aethlbert (issued between 597 - 616 AD) provided that a violation of church frith (the church's peace) was double that of an ordinary breach of the king's peace. ${ }^{243}$ This likely referred to church sanctuary; ${ }^{244}$

- Sanctuary was also referred to in later Anglo-Saxon laws ${ }^{245}$ including those of king Edmund (936-46 AD). ${ }^{246}$ As well as citing the need to prevent the blood feud (vendettas, private revenge) ${ }^{247}$ these laws referred to churches being places of sanctuary. Also, to the punishment for violating sanctuary. ${ }^{248}$ Similarly, the laws of king Canute

\footnotetext{
${ }^{237}$ Maitland, n 13, p 306. Stephen, n 55, vol 1, p 25 ' “Morth' means secret, and its use in the early laws seems not to be confined to cases of homicide, but to extend to all secret crimes.'

${ }^{238} \mathrm{P} \& \mathrm{M}, \mathrm{n} 88$, vol 1, p 52 'There are additional public penalties in aggravated cases, as where a man is slain in the king's presence or otherwise in breach of the king's peace. And a special application of the king's protection is made in favour of strangers; a matter of some importance when we remember that before the time of Alfred [king Alfred, 871-99 AD] a Mercian was a stranger in Kent, and a Wessex man in Mercia. Two-thirds of a slain stranger's wer goes to the king.'

${ }^{239}$ Ibid. Robertson, n 18, p 203 (Laws of Canute, 1016-35) 'If anyone dies by violence and it becomes evident that it is a case of murder [open moro], the murderer shall be given up to the kinsmen [of the slain man].' Hudson, n 18, p 166 'Moro is distinguished from other forms of homicide. It is often taken to refer to secret slaying, but may rather signify various forms of killing for which there could be no compensation, including killing linked to betrayal of one's lord and killing where the victim's body, or perhaps the deed more generally, was concealed.' See also O'Brien, n 19 (article) and Stephen, n 55, vol 3, p 27.

${ }^{240}$ Poison was closely linked to sorcery as well as to quack doctors.

241 e.g. Neill \& Gamer, n 217, (a) (Penitential of Finnian, c 525-50), p 88 'If anyone has started a quarrel and plotted in his heart to strike or kill his neighbour' (18 months' penance). Ibid, $\mathrm{p} 91$ 'If any cleric commits murder and kills his neighbor [7 years penance] ... but if he killed him suddenly and not from hatred [3 years]'; (b) (Penitential of Cummean, c 650), p 107 'He who commits murder through nursing hatred in his mind (odii meditatione $[$ [penance, to give up his arms until death]...but he who does this through anger, not from premeditation [3 years]...if he kills his neighbor unintentionally, by accident [1 year], (c) $6^{\text {th }} c$. Welsh synod), p 171 'He who slays his brother not with malice aforethought, if from sudden anger [ 3 years]; (d) (Penitential of Theodore, Archbishop of Canterbury, AD 668-90), p 187 'If a layman slays another with malice aforethought [7 years]... if through anger [3 years]...by accident [1 year]; (e) (Penitential ascribed to Bede, $c 8^{\text {th }} c$ ), pp 224-5 'He who slays a layman with malice aforethought [4 years]... he who slays through sudden anger and a quarrel [3 years]...by accident [1 year].'

${ }^{242}$ See $\mathrm{n} 90$

${ }^{243}$ Attenborough, n 18, p 5 'Breach of the peace shall be compensated doubly when it affects a church or a meeting place.'

${ }^{244}$ Cox, n 213, p 6. See generally, Hudson, n 18, pp 175-7. See also C Riggs, Criminal Asylum in Anglo-Saxon Law (1963).

${ }^{245}$ See e.g. Attenborough, n 18, p 39, (Laws of Ine, 688-725) 'If anyone is liable to the death penalty, and he flees to a church, his life shall be spared and he shall pay such compensation as he is directed [to pay] by legal decision.' See also Ibid, p 67, Laws of Alfred, 871-99), 'we grant to every church consecrated by a bishop this right of sanctuary etc...See also Ibid, p 149, Laws of Athelstan, 924-39)(immunity for 9 days). See also Robertson, $\mathrm{n} 18, \mathrm{p} 23$, (Laws of Edgar, 943-75) 'every right of sanctuary possessed by the church shall be maintained according to the highest standards of the past'. Ibid, $\mathrm{p} 97$ (Laws of Aethelred, 865-71) 'And every church shall be under the special protection of God and of the king and of all Christian people. And every right of sanctuary within the walls of a church, and the protection granted by the king in person shall remain equally inviolate.' See also Ibid, p 117. Also, Cox, n 213, pp 7-8.

${ }^{246}$ Robertson, n 18, p 3 .

${ }^{247}$ Ibid, $\mathrm{p} 11$ 'The authorities must put a stop to vendettas.'

${ }^{248}$ Ibid, p 9 'If anyone flees [for sanctuary] to a church....and anyone attacks or injures him there, those who do shall incur the penalty [i.e. forfeiture of property and outlawry].'
} 
(issued c. 1020) indicated that every church was a place of sanctuary and that killing therein was an unatonable crime. 249

What is unclear under Anglo-Saxon law, is whether sanctuary could be given to those who had committed premeditated killing (murder). ${ }^{250}$ Under Old Testament law, this was not possible (see 7) and one would suggest that the same may have applied - at least, under early Anglo-Saxon law.

\section{In conclusion, under Anglo-Saxon law (like Old Testament law), intentional killing which was not premeditated (such as} in a brawl) was atonable by paying compensation, if the kin of the victim accepted it.

\section{(e) Waylaying on King's Highway}

Biblical law did not made it clear what degree of protection there was when a person who killed another fled to a city of sanctuary but had not yet reached it.

- $\quad$ Could the victim's kin waylay him and legitimately kill him before he reached it? This issue would have arisen in the case of Anglo-Saxon England since outlaws and others ordered into exile (sorcerers, perjurers etc) would have had to journey along the highway to reach a port, in order to quit the country, ${ }^{25}$

- Likely, in part to prevent people being waylaid and killed in revenge killings, Anglo-Saxon kings asserted that their protection (mund) applied to certain major highways in England. Thus, the laws of Athelred (c. 1008) referred to the king's highway (although they did not expressly state what highways were embraced within such a reference). ${ }^{252}$

Under Anglo-Saxon law, it also seems that - in order to punish brigandage in general (that is, ambushing and assaulting, or robbing, people on highways) - a distinct crime, that of forsteal (forstal), arose under Anglo-Saxon law. Thus, the laws of Canute (c. 1020) stated:

These are the dues to which the king is entitled from all men in Wessex, namely, [the payments for] ...assault [forsteal]... ${ }^{253}$

As Maitland noted, the key element in committing this crime was premeditation - 'plotting' (scheming). ${ }^{254}$

- Forsteal also appears in the so-called Laws of William $I^{255}$ where reference is also made to the king's 'four' highways. ${ }^{256}$ Further, the Laws of Henry I (c.1113) clarified that this crime comprised ambush on a public highway; ${ }^{257}$

\footnotetext{
${ }^{249}$ Ibid. p 155 'Every church is rightly in the protection of Christ himself, and it is the special duty of every Christian man to show great respect for that protection, for the protection of God is of all kinds of protection most especially to be sought after and most zealously to be upheld, and next to that the protection of the king. Therefore it is very right and proper that the protection given by the church of God within its walls, and the protection granted by a Christian king in person should always remain inviolate; and he who violates either of them shall lose both land and life, unless the king is willing to pardon him. And if ever anyone henceforth violates the protection of the church of God by committing homicide within its walls, that crime shall not be atoned for by any payment of compensation, and everyone who is the friend of God shall pursue the miscreant, unless it happen that he escapes from there and reaches so inviolable a sanctuary that the king, because of that, grants him his life, upon condition that he makes full amends both towards God and towards men.' For an earlier version of king Aethelred (c. 1008), see Robertson, n 18, pp 118-9. How many killers sought sanctuary is unclear. O'Brien, $\mathrm{n} 19, \mathrm{p} 67$ notes that: 'There are very few post conquest [i.e. post 1066] stories that record the use of sanctuary to avoid punishment by criminals other than traitors.'

${ }^{250}$ Liebermann, $\mathrm{n} 226$, $\mathrm{p} 30$ thought that the Laws of Ine [688-725] permitted sanctuary even for murderers but that 'In Alfred's English Code [871-99], asylum is given for a number of days only, and two generations later, serious criminals are excluded from it altogether.'

${ }^{251}$ The port commonly used for the Continent was Dover (see also for English medieval law, Cox, n 213, pp 25-9). Waylaying and killing those abjuring the realm was, it seems, prevalent in medieval times as well since the statute of Articuli Cleri (1315-6), s 10 notes that 'where some flying unto the church, abjure the realm, according to the custom of the realm, and laymen or their enemies do pursue them, and pluck them from the king's highway, and they are hanged or beheaded...' See also Cox, n 213, p 18. Also, Trenholme, n 213, pp 40-1 for cases in 1267 and 1276 of those who had left the highway, were pursued, and killed. See also J Bellamy, Strange, Inhuman Deaths. Murder in Tudor England (2005), p 42 (a murderer abjuring the realm was stoned to death on the way to the port of embarkation).

${ }^{252}$ Robertson, $\mathrm{n} 18, \mathrm{p} 75$ 'he who assaults an innocent person on the king's highway, if he is slain, shall lie in an unhonoured grave'. See also p 325 which indicates that this is a reference to forsteal.

${ }^{253}$ Ibid, p 181. Thus, the fines for this offence went to the king. See also P \& M, n 88, vol 2, pp 453-4; Hudson, n 18, p 50 and Stern, n 98 , p 482.

${ }^{254}$ Maitland, $\mathrm{n} 13, \mathrm{p} 311$ 'the crime called foresteal is committed, and the king becomes entitled to a fine of a hundred shillings if $\mathrm{A}$ lies in wait for B on the king's highway, assaults him, and is taken in the very act but it is not foresteal if A instead of attacking B on the flank lets him pass and calls him back, and then there is a fight in which B gets the worst....Foresteal, literally the anticipating of another, the placing of oneself before another, is then an ambush, a plotted assault upon the king's highway.' P \& M, n 88, vol 2, pp 455 'The English forsteal had its Norman representative in the plotted assault, assultus excogitatus de veteri odio, guet apens.'

${ }^{255}$ Robertson, n 18, p 253 'he who violates the king's peace shall pay 100 shillings as compensation in the province of Mercia. And similarly for... pre-meditated waylaying [de agwait prepense]. These pleas belong to the king's Crown.'

${ }^{256} \mathrm{Ibid}, \mathrm{p} 267$ 'If anyone slays or assaults anyone who is travelling through the country on any of the (following) four highways, namely, Watling Street, Ermine Street, the Fosse Way, the Icknield Way, he violates the king's peace.' These refer to certain Roman, or pre-Roman, roads, Ibid, p 369. Watling Street led to Dover. See also n 251 and O'Brien, n 19, pp 169 \& 270.

${ }^{257}$ Downer, $\mathrm{n} 20$, p 249 'If an assault is made on anyone on the king's highway, this is the offence of forestel, and compensation amounting to [100s] shall be paid to the king....The offence of forestel occurs if someone attacks his enemy unexpectedly or lies in wait for him on the road and assaults him. But if he waits until he has passed and calls out to him, so that he returns to meet him, it is not forestel if he (the person waiting) acts in self-defence.' Forestel was a plea of the Crown. Ibid, pp 109, 115. See also pp 324-5 (where the original meaning is asserted to have been 'obstruction of the functioning of the law', which would seem appropriate since it was an attempt to negate the legal effect of sanctuary).
} 
- Although forsteal was a distinct crime of assault (with an ancient pedigree) ${ }^{258}$ and it did not require the victim to be killed for it to be committed, it is of interest since it seems clear that - where a person was waylaid (assaulted) and killed - this was treated as an example of premeditated killing and, thus, was not atonable.

- It is asserted this distinct crime of forsteal, in time, in English law became reduced to one of highway robbery - with any other assault on a highway becoming one of battery;

- Today, highway robbery no longer exists as a distinct crime; it is covered by the general crime of robbery (see Theft Act s 8(1), 'A person is guilty of robbery, if he steals, and immediately before or at the time of doing so, and in order to do so, he uses force on any person or puts or seeks to put any person in fear of being then and there subjected to force.').

In conclusion, in Anglo-Saxon law, to ambush and kill a person on the king's highway was treated as an example of premeditated killing. Just as assaulting a person on the king's highway (whether to rob or batter them) was also treated as premeditated.

\section{(f) $\underline{\text { Murder Fine }}$}

As noted in (a), premeditated killing was not atonable; the death penalty applied. However, where the person killed was a Dane (Viking), then a specific fine was imposed on the community when the killer could not be produced. ${ }^{259}$ This murder fine (murdrum) continued into Anglo-Norman times in the case of the secret killing of a Frenchman. As to this:

\section{(i) Secretly Killing Danes}

- In Anglo-Saxon England, as from AD 866, Danish armies (Vikings) began to winter in England, as opposed to raiding periodically. They brought with them their Danelaw. Eventually, the Danes put an end to all English kingdoms, save for that of Wessex;

- In the reign of king Canute (1016-35) - perhaps in 1017 or 1018 - in return for his sending his army back to Denmark, the English nobles agreed that a fine was to be paid in the case where a Dane was slain and his killer was not produced. Doubtless, this was due to a fear that - in the absence of a Danish army - the English would secretly kill those Danes who remained in England, ${ }^{260}$ something which likely occurred in $1002 ;^{261}$

- This arrangement was (it seems) agreed to by means of a treaty. Therefore, it was not reflected in the laws of Canute as such. ${ }^{262}$ However, the (alleged) Laws of Edward the Confessor (1042-66) made reference to it. They stated:

'Murder fines [murdra] were devised in the time of king Cnut, who, after he had acquired the land and pacified it with him, sent his army home at the request of the barons of the land. And those same [barons] were sureties to the king that those whom he retained in the land would have a lasting peace. Thus, if any of the English slew any of those men, justice would be done on him if he could not acquit himself by the ordeal, whether of [hot] iron or water. If, however, he fled, payment would be made as was described above.' 263

Bracton (writing c. 1240) was likely familiar with these Laws of Edward the Confessor since his commentary was similar. 264

\section{(ii) Secretly Killing Frenchmen}

- After the Norman Conquest of 1066, this murder fine was applied to the killing of Frenchmen where the killer was not produced. Thus, the (asserted) Laws of William I provided that:

\footnotetext{
258 See Babylonian law (brigandage), see n 110.

${ }^{259} \mathrm{P} \& \mathrm{M}, \mathrm{n} 88, \mathrm{vol} 2, \mathrm{p} 487$ 'This fine...was a fine occasioned by a secret homicide, a homicide secret in this sense that no one was brought to justice as its author.'

${ }^{260}$ O'Brien, n 19, pp 175, 272. Reeves, n 221, vol 1, p 17 'It is said that Canute, being about to leave the kingdom, and afraid that the English might take advantage of his absence to oppress or destroy his own subjects, the Danes, procured the following law in order to prevent secret homicides: that when any person was killed, and the slayer had escaped, the person killed should be always considered as a Dane, unless proved to be English by his friends or relations; and in default of such proof, that the vill should pay forty marks for the Dane's death; and, if it could not be raised in the vill, that the hundred should pay it. This singular provision, it was thought, would engage everyone in the prevention or prosecution of such secret offences. It was upon this sort of policy that presentments of englishry, as they were afterwards called, were founded.'

${ }^{261}$ On 13 November 1002 (St Brice's Day), it seems that king Aethelred ordered the killing of all Danes in England and it is likely that massacres took place. See D Whitelock, The Anglo-Saxon Chronicle (Eyre \& Spottiswoode, 1965) p 86, O’Brien, n 19, article, p 354 and Hale, n 45 , vol 1, p 447.

${ }^{262}$ Did such an agreement actually exist? O'Brien, n 19 (article) assembles evidence for it and that the murder fine was created by Canute and not William I. Frequent references to this being so would seem persuasive as would the need for Canute to prevent a massacre of Danes such as had occurred in 1002 (see n 261).

263 O'Brien, n 19, p 173. The Laws also provided: 'When anyone anywhere was found murdered, the slayer of this person was sought in the vill where [the body] was found; and if he could be found, he was handed over to the king's justice within eight days of the slaying. If, however, he could not be found, they had a month and a day as respite to locate him. If he was not found, forty-six marks were collected from the vill...' See also Stephen, $\mathrm{n} 55$, vol $1, \mathrm{pp} 25-6$

${ }^{264}$ Bracton, n 22, vol 2, p 397. 'The reason for the devising of murder-fines was this: in the days of Cnut, king of the Danes, when at the prayer of the English barons he sent his army back to Denmark after he had conquered and pacified England, the barons of England offered themselves as sureties to the said king Cnut that, whatever the force the king kept with him in England they would have firm peace in all things so that, if anyone of the English should slay any of the men whom the king kept with him and if that man could not make his defence against the charge by the judgment of God, that is, by water or iron, justice would be done upon him. If he fled away and could not be arrested they would pay on his behalf sixty-six marks, to be collected in the vill where he was slain, because the inhabitants did not pay the slayer. And if the marks could not be collected in the vill because of its poverty, they would be collected in the hundred for deposit in the king's treasury.'
} 
'If a Frenchman is slain and the men of the hundred do not seize the slayer and bring him to court within 8 days, in order to prove who has done it, they shall pay the murder-fine, namely 46 marks.' 265

This fine was abolished in $1340{ }^{266}$ (it had been in decline since 1130 with exemptions and reduced payments) ${ }^{267}$ and the word 'murdrum' was then transposed (merged) into the concept of premeditated killing. Thus, the word 'murder' is usually said to derive from a specific fine imposed on a community in Anglo-Saxon (and Anglo-Norman) times - although this may not be correct and it may be that, in Anglo-Saxon times, it was used generally as an expression to cover premeditated killing, an example of which was the secret killing of Danes or Frenchmen. ${ }^{268}$

In conclusion, the killing of a Dane where the killer was not produced, resulted in the community having to pay a fine (Babylonian law had had a similar system (see $n$ 110). Such a killing would have been treated as premeditated (secret). Therefore - if the killer was found - the death penalty would have been imposed.

\section{(g) Justifiable Killing}

As with Old Testament and Roman law, Anglo-Saxon law held the killing of a person to be justifiable in certain circumstances such that no crime was committed and no blood feud resulted. Thus, it was lawful for a person to kill:

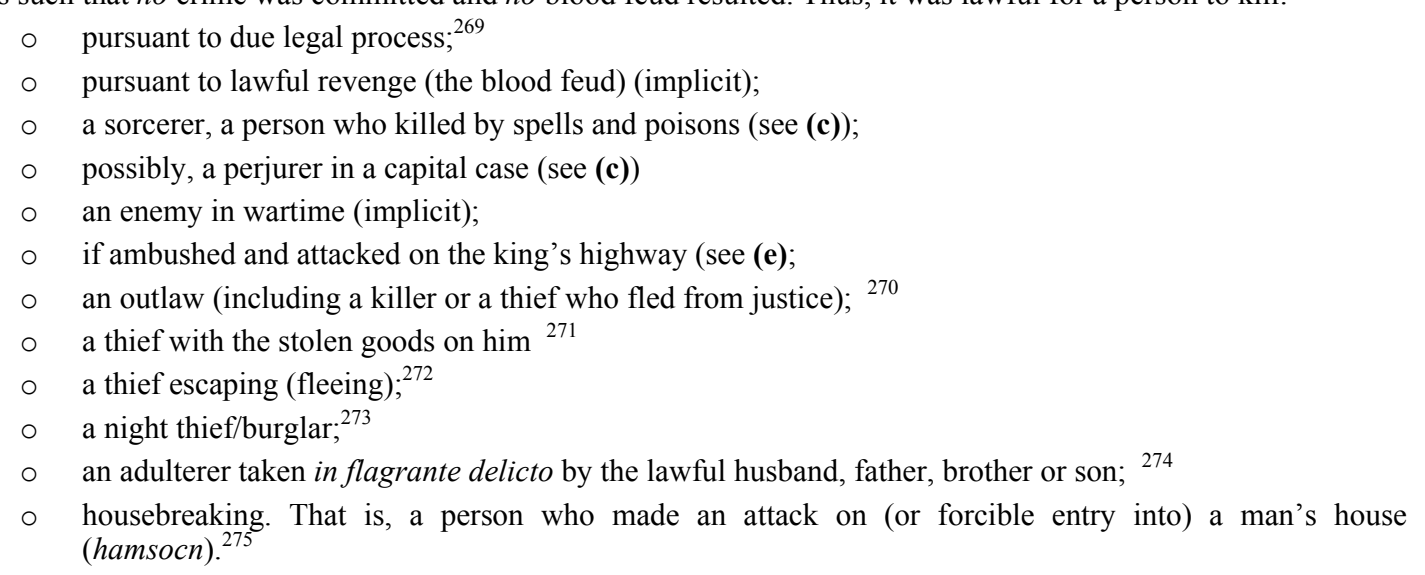

${ }^{265}$ Robertson, n 18, p 265. F Stenton, Anglo-Saxon England ( $3^{\text {rd }}$ ed, 1971), p 685 'The regulation probably belongs to an early part of the Conqueror's reign, when most of the Frenchmen in England were attached to the households of knights or barons, and it gives no more than a point of departure for the mass of custom which rapidly developed around the murder fine and presentment of englishry.'

26614 Edw III stat 1 c 4 (1340, rep).

267 See Yntema, Lex Murdrorum, Harvard LR, vol 36, pp 177-8. Also, O’Brien, n 19, article, p 355.

268 See n 88.

${ }^{269}$ Anglo-Saxon law does not seem to expressly provide for this. However, see an early penitential which reflect the church position. McNeill \& Gamer, $\mathrm{n} 217, \mathrm{p} 81$ (Canons attributed to St Patrick, $c 5^{\text {th }} c$ ) 'Hearken again unto the lord when he saith, 'Whosoever shall shed innocent blood, his blood shall be shed': but [it is to be shed] by him who carries the sword; moreover, the chief magistrate is held innocent in punishment.'

${ }^{270}$ An outlaw bore the wolf's head (i.e. was treated the same as a wolf, a dangerous pest) and could be executed summarily. P \& M, n 88, vol 1, p 53 'An outlaw might... be slain with impunity; and it was not only lawful but meritorious to kill a thief flying from justice. An adulterer taken in flagrante delicto by the woman's lawful husband, father, brother, or son, might be killed without excuse of blood feud.' See also Ibid, vol 2 , p 449.

${ }^{271}$ Attenborough, n 18, p 29 (Laws of Wihtred, 690/1-725) 'If anyone slays a man in the act of thieving, no wergeld shall be paid for him.' Ibid, p 41 (Laws of Ine, 688-725). 'If a thief is taken he shall die the death [summary execution], or his life shall be redeemed by the payment of his wergeld.' Ibid. 'He who kills a thief shall be allowed to declare on oath that the man he slew was guilty.' Ibid, (Laws of Aethelstan, 924-39) p 127 'no thief shall be spared, who is seized in the act, if he is over twelve years old and [if the value of the stolen goods is] more than 8 pence.' See also Robertson, $\mathrm{n} 18$, $\mathrm{p} 189$ (Laws of Canute, 1016-35) 'the proved thief...shall never be able to save his life.' Such thieves were often called 'hand having' (stolen goods in the hand) or 'back bearing' (carrying stolen goods on their back). See also Hudson, n 18, p 168. Attenborough, n 18, p 45 (Laws of Ine, 688-72) provided an option for the person to turn over the thief to the king for a reward 'He who captures a thief shall have 10 shillings. The thief shall be given up to the king, and his kinsmen shall swear that they will carry on no vendetta against him...If he [the captor] wishes to deny his culpability, he must render an oath equivalent to the value of the stolen goods and the fine.' See also Holdsworth, n 65, vol 2, p 44.

${ }^{272}$ Ibid, p 47 (Laws of Ine, 688-725) 'He who kills a thief shall be allowed to declare with an oath that he whom he killed was a thief trying to escape, and the kinsman of the death man shall swear an oath to carry on no vendetta against him.' Ibid, (Laws of Aethelstan, 924-39), p 127 'if...[the thief] tries to defend himself, or if he takes to flight, he shall not be spared.' Ibid. p 149 'if ...he [the thief] takes to flight, he shall be pursued to his death by all men who are willing to carry out the king's wishes, and whoever shall meet him shall kill him.' Ibid, p 169 'no one shall be slain for the theft of property worth less than 12 pence unless he is minded to flee or defend himself. But in that case there shall be no hesitation, even if the property is of less value.' See also Holdsworth, n 65, vol 2, p 44

273 Thorpe, n 18, p 23 (Laws of Alfred, 871-99, Introduction), 'If a thief break into a man's house by night, and he be there slain; the slayer shall not be guilty of manslaughter. But if he do this after sunrise, he shall be guilty of manslaughter, and then he himself shall die, unless he were an unwilling agent [i.e. acted in self defence].'

${ }^{274}$ Attenborough, n 18, p 85 (Laws of Alfred, 871-99) 'A man may fight, without becoming liable to vendetta, if he finds another [man] with his wedded wife, within closed doors or under the same blanket; or [if he finds another man] with his legitimate daughter [or sister]; or with his mother, if she has been given in lawful wedlock to his father.' In the time of Canute (c. 1020) a woman caught in adultery lost her nose and ears, see Robertson, $\mathrm{n} 18$, $\mathrm{p} 203$. See also Hudson, n 18, p 173 'killings so justified that no vengeance was merited.'

275 As Hudson notes, $\mathrm{n}$ 18, p 20, it may also have referred to an assault on a person in his house. 'Ham' was Anglo-Saxon for a house. Robertson, $\mathrm{n}$ 18, p 75 (Laws of Aethelred, 165-711) 'a man who, within the town, makes forcible entry into another man's house without permission and commits a breach 
As with Old Testament (and Babylonian) law, it is likely that this crime of 'house breaking' included not just the house but the courtyard (or palisade) that enclosed the house, ${ }^{276}$ which would likely have comprised a wall or wooden stakes. Therefore, this was not a matter of a person breaking in accidentally or negligently. This would have required considerable effort. The justification for being able to kill such a person was that the owner of the house would not know the intention of the housebreaker, whether he had come to kill or to steal. Killing also in such circumstances would have been treated as akin to self-defence.

In Babylonian, and Old Testament, times it was lawful to kill a perjurer in a capital case. In Anglo-Saxon times, the position was less clear. However, the later Laws of Henry I (see 10) suggest that a perjurer (even in a capital case) could not be justifiably killed by the victim's kin, but those who killed by witcheraft or poison could, being handed over to the kin for execution.

\section{(h) Excusable Killing}

Anglo-Saxon law also held certain killings to be excusable. That is, where a crime was committed, but there was a valid defence and compensation was sufficient to avert a blood feud. These were treated the same as an accidental killing and they covered:

$$
\begin{aligned}
& \circ \text { self defence; }{ }^{277} \\
& \circ \quad \text { defence of one's lord (or of a man whose lord he was); }{ }^{278} \\
& \circ \quad \text { defence of one's kin. }{ }^{279}
\end{aligned}
$$

\section{(i) Anglo-Saxon Law - Conclusion}

Plucknett noted that murder was the product of different lines of development and had a devious history. ${ }^{280}$ This is true. However, thanks to more modern translations of the Old Testament and Anglo-Saxon law, it seems clear that Anglo-Saxon law closely followed Old Testament law.

- Blood Feud. As with Old Testament law, Anglo-Saxon law sought to mitigate the effect of the lex talionis (life for life) and the blood feud obligation imposed as a result;

- $\quad$ Accidental. As with Old Testament law, Anglo-Saxon law treated accidental killing as atonable. Compensation could be paid and the death penalty avoided, unless the kin of the man killed refused to accept compensation. Negligent killing and killing in self defence (or defending one's kin or lord), were treated as aspects of accidental killing;

- $\quad$ Premeditated. As with Old Testament law, in Anglo-Saxon law, this was unatonable and the death penalty applied. Evidence (and, likely, a presumption) of premeditation included: (a) killing a person by sorcery (putting a death spell on them); (b) killing a person by poison; (c) waylaying (ambushing) and killing a person; (d) killing a person where there was evidence of a prior grudge or hatred towards the victim; (e) concealing the body of the victim;

- Killing in a Brawl. As with Old Testament law, this was atonable under Anglo-Saxon law. Compensation could be paid and the death penalty avoided, unless the kin of the man killed refused to accept compensation;

- Justifiable. As with Old Testament law, certain forms of killing were treated as justifiable and, thus, were not treated as crimes (so, no blood feud), see (g);

- Excusable. This was treated the same as accidental killing. It covered killing: (a) in self-defence; (b) in defence of one's lord; and (c) in defence of one's kin;

- 'Malice Aforethought'. Both Maitland ${ }^{281}$ and Plucknett ${ }^{282}$ thought that the term 'malice aforethought' was derived in some way from the Anglo-Saxon forsteal (ambushing a person in a highway). However, neither

of the peace of the worst kind [possibly it refers to homicide]...if he is slain, shall lie in an unhonoured grave.' Ibid, p 205 (Laws of Canute c. 1020) 'If a man makes a forcible entry into another man's house... if he is slain in such a case, no compensation shall be paid for his death.' Ibid, $\mathrm{p} 207$ 'assaults upon houses... are crimes for which no compensation can be paid.' Ibid, p 358 'The difference between hamsocn and husbryce seems to be that the latter involves destruction or damage to the house itself...' Cf. Hudson, n 18, p 165-6 'The more specific offences referred to as hamsocn and husbryce (house-breaking) involved violence against people within the building or perhaps against the building itself, not simply breaking in and removing goods.' See also Reeves, $\mathrm{n} 221$, vol 1, p 16. Roman law treated the forcible entry into a man's house as an iniuria (wrong). See Robinson, n 180, p 49. It may be noted that Roman law also made this a crime, a capital one. Digest, n 182, bk 48.6.11. Paul, Views, bk 5 'Those who loot, break open, or storm the homes or country houses of others, if, indeed, they gathered an armed mob, receive capital punishment.'

${ }^{276}$ Goebel, n 216, pp 13-4, referring to early continental German law (Lex Salica), which would have been the same as Anglo-Saxon law, noted 'the existence in the Lex Salica of a particular offense of close breaking at a period when breaking into the house itself has become more severely tariffed suggests that it was originally the enclosure which was protected.' This is supported by Attenborough, $\mathrm{n}$ 18, p 9 (Laws of Athelred, 865-71) which make it an offence 'If a freeman breaks the fence around [another man's] enclosure' [6s compensation]. Also, 'If any property be seized therein, the man shall pay a threefold compensation'. Also, 'If anyone damages the enclosure of a dwelling, he shall pay according to its value.' See also Tacitus, $\mathrm{n} 8$, $\mathrm{p} 114$ 'Every man leaves an open space round his house...'.

277 Anglo-Saxon law does not explicitly state this. However, it is implicit from the other defences. The Laws of Henry I expressly provide this, see $\mathrm{n} 315$ (text). See also Holdsworth, n 65, vol 2, p 44.

${ }^{278}$ Attenborough, n 18, p 85, (Laws of Alfred, 871-99), p 85 'a man may fight on behalf of his lord, if his lord is attacked, without becoming liable to vendetta. Under similar conditions a lord may fight on behalf of his man.'

${ }^{279}$ Ibid. 'a man may fight on behalf of one who is related to him by blood, if he is attacked unjustly..' See also Hudson, n 18 , p 173 , P \& M, n 88 , vol 1 , p 53 \& Holdsworth, n 65, vol 2, p 44.

${ }^{280}$ Plucknett, n 221. See also Yntema, n 267, pp 146-79.

281 See Maitland, n 13 and P \& M, n 88, vol 2, p 455.

282 Plucknett, n 221, p 444 'Even before the conquest, however, deliberately planned assassinations came to be distinguished and put into the list of Crown pleas as forsteal. The original sense of this word was lying in wait to ambush the victim. After the conquest this is expressed in various terms in 
considered Old Testament law in detail. Forsteal was an example of premeditation, ${ }^{283}$ but was certainly not the source - since this crime (brigandage) in Anglo-Saxon law was committed without a pre-requisite that the person also be killed. Instead, 'malice aforethought' was much older than this Anglo-Saxon crime. It derived from the Old Testament, to refer to a killing which - being secretly 'plotted' or 'schemed' - was unworthy of compensation and, therefore the death penalty applied, without mitigation. This crime of premeditated killing was called 'morth' in Anglo-Saxon law - a 'secret' killing which distinguished it from an 'open' killing, such as in a brawl.

\section{Laws of Henry I (c. 1113)}

The Anglo-Saxon tariff continued after the Conquest and was present in the Laws of Henry I (c. 1113).

- These laws - in respect of homicide - added little to the Anglo-Saxon tariff. They continued the basic 'unit' for the tariff, that is, in the case of a freeman (or slave) who was killed, their wergeld was payable; ${ }^{284}$

- Further, as with Anglo-Saxon law (see 9), the Laws of Henry I made it clear that the status of the victim, and the place where he was slain, dictated the amount of wergeld payable. ${ }^{285}$

The Laws of Henry I contained a general statement as to the nature of homicide:

Homicide is committed in many ways, and within its definition there are great differences depending on the circumstances of the case and the persons involved... ${ }^{286}$ Homicide is committed by accident or by design (casu, consilio). ${ }^{287}$ (underlining supplied)

In respect of the description of homicide it is clear that it was heavily influenced by theology since the text also states that homicide is:

committed sometimes through greed or quarrels over worldly matters, it is committed also as the result of drunkenness or on someone else's command. It is also committed in self defence or in a just cause, and the blessed Augustine in his 'On the Lord's Sermon on the Mount' refers to these things in the following way:

'If homicide is killing a man, it can sometimes happen without committing sin; for a soldier who kills his enemy, and a judge a criminal, and a person from whose hand a spear flies perhaps involuntarily or accidentally, do not seem to me to commit a sin when they kill a man. ${ }^{288}$

The blessed Jerome says:

'Punishing murderers...is not a shedding of blood, but the due application of the laws. The Law [Bible] itself says: 'If you let escape a man worthy of death, your life shall stand in place of his life. ${ }^{289}$ (wording divided for ease of reference)

The division of homicide into: (a) intentional; and (b) accidental was the same as Anglo-Saxon law. So too, the sub-division of (a) into premeditated and unpremeditated killing. This is now considered:

\footnotetext{
French and Latin, but frequently takes the form of assault purpense, or assultus premeditatus. In time this yields before malitia excogitata, and so introduces us to the very troublesome word 'malice'. Numerous pardons for accidental slayings explain that the offence was not done of malice aforethought, but on the positive side the word was used very vaguely; it seems impossible to maintain that it signified spite or hate, or indeed any definite allegation of intention. It is best regarded as a traditional form which only occasionally coincided with the natural meaning of the word...'.

${ }^{283}$ The reference to assultus premeditatus (in latin), agwait or assault prepense (in Anglo-Norman) and gut apens (in more modern French) all summed up forsteal and more since they referred not just to ambush on a highway but any battery (assault) which was premeditated.

${ }^{284}$ Downer, n 20, p 215 'If anyone, either a freeman or a slave, is slain he shall be compensated for lawfully by the amount of his wergeld.' Ibid, p 237 'If a man is slain he shall be paid for according to the amount of her wergeld...when this has been done, the king's peace shall be established between them.' Hudson, n 18, p 385 'Overall there does not seem to have been any marked shift in the classification of wrongs since the Anglo-Saxon period.' See generally, Hudson, n 18, ch 16.

${ }^{285}$ Ibid, p 215 'Circumstances produce different consequences in everything: depending on the place, for example, whether the offence occurs in a church or the king's dwelling or during military service or in the king's household or in a town or in any permanent abode of this kind enjoying the protection of peace; or depending on the time, for example whether the day is a festival day, or whether the king is with his personal troop or in the county itself; or depending on the person concerned, for example whether he is a servant of the king, or a reeve or official of some other lord, or in whatever capacity he secures the untroubled calm of peace, whether by writ or some other method.'

286 Ibid, p 227.

${ }^{287}$ Ibid, pp 228-9.

288 The reference to the text of Augustine is incorrect. It is to another. T Williams (trans), Augustine. On Free Choice of the Will (Hackett Pub Co, 1993), pp 6-7 where Evodius states: 'If murder is just killing a human being, then there can be murder that is not sinful. When a soldier kills the enemy, when a judge or his representative puts a criminal to death, or when a weapon accidentally slips out of someone's hand without his willing or noticing it: there people do not seem to me to be sinning when they kill someone.' Augustine replies 'I agree, but such people are not usually called murderers.' Later, at p 8, Augustine states (by way of argument but clearly supporting the legal position): 'Then the [Roman] law is unjust that permits a traveller to kill a highway robber in order to keep from being killed himself, or that permits anyone who can, man or woman, to kill a sexual assailant, before he or she is harmed. The law also commands a soldier to kill the enemy; and if he refuses, he is subject to penalties from his commander. Surely, we will not dare to say that these laws are unjust, or rather, that they are not laws at all.' See also H Bettenson (trans) St Augustine, City of God (Penguin, 1972), bk 1, ch 18, p 32 'There are however certain exceptions to the law against killing, made by the authority of God himself...For this reason the commandment forbidding killing was not broken by those who have waged wars on the authority of God, or those who have imposed the death penalty on criminals when representing the authority of the State in accordance with the laws of the State, the justest and most reasonable source of power.'

289 Saint Jerome, Commentaria in Hieremiam (Commentary on Jeremiah), IV, 35 'To punish murderers, those who commit sacrilege, and poisoners, is not to shed blood. It is the ministry of the laws.' Both Augustine and Jerome likely had as their source St Paul, Romans, 13:4 '[the ruler] does not bear the sword for nothing. He is God's servant, an agent of wrath to bring punishment on the wrongdoer.' See also JQ Whitman, The Origins of Reasonable Doubt (2008), p 39 and M Graves (trans) Commentary on Jeremiah (2011), p 129.
} 
- $\quad$ Accidental. The Laws of Henry I stated a basic proposition that: 'A person is not to be considered guilty unless he has a guilty intention.' 290 Thus, a killer should often be held 'blameless' in the case of accidental death ${ }^{291}$ and mercy - rather than judgment - should be applied. ${ }^{292}$ That is, the killer and victim's kin should settle the matter between themselves. However, it seems clear that, even if blameless, compensation was still payable in the case of accidental killing, including during a game. ${ }^{293}$ The Laws of Henry I also seem to have developed the rudiments of negligent killing, for which compensation was payable; ${ }^{294}$

- $\quad$ Premeditated. Morth was not atonable. ${ }^{295}$ The death penalty applied and the killing could not be satisfied by way of compensation. It is also unlikely any pardon could be granted; ${ }^{296}$

- Unpremeditated. Where the killing was intentional but not premeditated (such as in a brawl), compensation was possible. ${ }^{297}$ This was the same as under Anglo-Saxon law. Further the rationale (as with Old Testament and Babylonian law) was likely based on the general assumption that it took two to quarrel; 298

- Murder Fine. The Laws of Henry I continued the murder fine (see 9(f)). It was 46 marks, payable by the vill (village) if the killer could not be produced within 7 days. ${ }^{299}$ It appears this fine had been extended from the secret killing of a Frenchman to also cover: (i) any foreigner (person from across the sea); ${ }^{300}$ (ii) where the killer was known but not captured within 7 days thereafter. ${ }^{301}$ The murder fine, likely, was a 'money spinner' for the Treasury, since levying of this fine was a Crown prerogative. ${ }^{302}$ There was also an incentive to inform in respect of such a killing, to help ensure that it was revealed; ${ }^{303}$

- Justifiable. The Laws of Henry I seem to have closely followed Anglo Saxon law. Thus, it was lawful for a person to kill:

○ pursuant to due legal process; ${ }^{304}$

\footnotetext{
${ }^{290}$ Downer, n 20, p 95 'Rerum non facit nisi mens rea.' There was also a difference in penance, see McNeill \& Gamer, n 217, passim. See also AKR Kiralfy, Potter's Outlines of English Legal History (1958), p 157 'the church, in her penitential books, which had exercised a considerable influence on the law of bot and wite, laid stress on the mental element in sin.' There is no doubt that the Laws of Henry I (like Anglo-Saxon law) evidences considerable ecclesiastical influence.

${ }^{291}$ Ibid, p 283 'If a man falls from a tree or some man-made structure on to someone else so that as a result the latter dies or is injured, if he can prove that he was unable to avoid this, he shall in accordance with ancient ordinances be held blameless.' See also p 223 and Hudson, n 18, p 411. Downer, n 20, p 269 'Concerning the committing of wrongful deeds by weapons, by which someone is slain. If anyone runs against or falls on a person's weapons so that as a result he dies, and it is evident that it is the fault of himself alone, then the responsibility shall lie there. However, the person whose weapons they were shall not carry them carelessly. In legal proceedings of this kind consideration must be given to the manner of carrying or laying down weapons, the place in which they were laid down, the person who laid them there, what happened, and how it happened.' (italics supplied)

${ }^{292}$ Ibid, p 283 'There are many kinds of misfortune which occur by accident rather than by design and which should be dealt with by the application of mercy rather than by formal judgement.' Also, p 273 'No one is obliged to make amends for his own child whom he did not kill intentionally, neither by way of money compensation nor by physical mutilation.' Cf. p 271 'If anyone kills or while sleeping crushes another person's child who has been entrusted to him for rearing or instruction, he shall pay compensation for him just as if he had killed an adult person.' See also n 291.

${ }^{293}$ Ibid, p 271 'If a person in the course of a game of archery or of some exercise [possibly, it refers to some military exercise] kills anyone with a spear or as a result of some accident, he shall pay compensation to him. For it is a rule of law that a person who unwittingly [unintentionally] commits a wrong shall consciously make amends.' As Holdsworth noted, $\mathrm{n} 65$, vol 2, pp 51-2, this idea of the criminal liability of a person who killed by accident (or self defence) continued in the law until 1828 , when forfeiture for it was abolished.

${ }^{294}$ Ibid 'If anyone carries a spear on his shoulder, and someone is killed by it, compensation to the extent of his wergeld shall be paid, without imposition of the wite. If the point of the spear is carried before the eyes of the bearer, he shall pay the wergeld of the dead man...If the end and the point of the spear are on the same level, no blame shall attach to the person carrying it. [i.e. he is not negligent].'

${ }^{295}$ Ibid, p 115 'Some pleas cannot be compensated for with money; these are...palpable murder [ebere morth]...' See also P \& M, n 88, vol 2, p 458. The word 'palpable' (aebaere, notorious) suggests that it is dealing with premeditated ('secret') homicide and not 'open' homicide (such as in a brawl).

${ }^{296}$ Ibid, p 117. The pleas 'which place a man in the king's mercy' do not include it. Homicide by sorcery was treated as premeditated and murder. See Downer, n 20, p 227 'If anyone commits homicide by means of a magic potion or witchcraft or sorcery practiced with images or by any kind of enchantment whether it was intended for the person killed or for someone else, there is no escape from the fact that the deed is one causing death and is not to be compensated for in any way. A person who falls within this category shall be handed over to the kinsmen and friends of the slain man, so that he may experience the mercy and judgement of those whom he himself did not spare.' See also Stephen, n 55, vol 3, p 27.

${ }^{297}$ Ibid, p 215 'If anyone, either a freeman or slave, is slain he shall be compensated for lawfully by the amount of his wergeld ...'. See also pp $235,237$. The Anglo-Saxon tariff (see App A) would still also apply. P \& M, n 88, vol 2, p 458 'a mere wilful homicide, when there has been no treachery, no sorcery, no concealment of the corpse, no sacrilege, no breach of a royal safe-conduct, is not unamendable. It still, if not duly paid for, exposes the slayer to the vengeance of the slain and the slain man's kin. But it can be paid for.'

${ }^{298}$ Ibid, p 261 'Where one is unwilling, two persons do not come to blows. Every lawbreaker is brother to another. He who answers a fool according to his folly is like unto him.'

${ }^{299} \mathrm{Ibid}, \mathrm{p} 117$ 'The penalty for murdrum shall be the payment of forty-six marks, unless the offender is captured within seven days.' See also Hudson, n 18 , pp 405-9.

${ }^{300}$ Downer, n 20, p 285 'If any Frenchman or Norman or indeed any person from across the sea is slain, and the matter turns out so disastrously that it becomes a case of murdrum, and the slayer is unknown or takes to flight, so that he is not surrendered to a royal justice within seven days for the execution of whatever is just, forty-six silver marks shall be paid; forty marks shall belong to the king and six to the relatives of the slain man.' See also p 235 .

${ }^{301}$ Ibid, p 289.

${ }^{302}$ Ibid, p 109 'These are the jurisdictional rights which the king of England has in his land solely and over all men...murdrum.' See also p 175.

${ }^{303}$ Ibid, p 235 'If a Frenchman who has no relatives is the victim of murdrum, the person who made known the murdrum shall be entitled to the amount of his wergeld.'

${ }^{304}$ See n 288 (following St Augustine).
} 
- pursuant to lawful revenge (the blood feud) (although this was further curtailed, see text to n 319);

- a person who killed by witchcraft or poison; ${ }^{305}$

$\circ \quad$ an enemy in war time (implicit); ${ }^{306}$

○ if ambushed and attacked on the king's highway; ${ }^{307}$

an outlaw; ${ }^{308}$

- a thief with the stolen goods on him or who was, otherwise, manifestly guilty. ${ }^{309}$

$\circ \quad$ a thief escaping (fleeing); 310

$\circ \quad$ a night thief (burglar); ${ }^{311}$

○ a housebreaker. ${ }^{312}$

Under Anglo-Saxon law, it was uncertain whether a perjurer in a capital case could be justifiably killed. It was likely not (a change from the Old Testament position). In the Laws of Henry I, this also seems to be the case. ${ }^{313}$ Further, it would not seem justifiable, by this time, to summarily kill an adulterer caught in flagrante; ${ }^{314}$

- Excusable. The Laws recognised the right of self-defence, as well as defence of one's kin and one's lord, stating: 'Any person may defend himself in any matter except against his lord...Anyone may defend himself, if someone attacks him, in every place or circumstance, except against his lord...' 315 Further, a person did not have to wait before exercising self-defence. ${ }^{316}$ However, acting under 'superior orders' was not a defence. ${ }^{317}$ Excusable homicide still incurred an obligation to compensate the victim's kin. ${ }^{318}$

\footnotetext{
${ }^{305}$ See $\mathrm{n}$ 296. Cf. the (alleged) Laws of William I (actually written c. 1140's), see Robertson, n 18, p 269, 'If a man poisons another, he shall be slain or sent into permanent exile.'

${ }^{306}$ There is no reason to suppose that the position under Anglo-Saxon law had changed in this respect, see $\mathrm{n} 288$. The Laws of Henry I provided that such a man should do penance. Downer, n 20, p 219 'Anyone who kills a man in a national war...shall do the same amount of penance.' This seemed to be one of bread and water for 40 days. Also, for 3 periods in Lent (together with the lawful feast days) to abstain from flesh and drink. Ibid, p 217.

307 The Anglo-Saxon offence of forsteal continued and remained a plea of the Crown. Downer, n 20, p 115 'Compensation is effected by the payment of one hundred shillings for... forestel.' Ibid, p 249 'The offence of forestel occurs if someone attacks his enemy unexpectedly or lies in wait for him on the road and assaults him...If an assault is made on anyone on the king's highway, this is the offence of forestel, and compensation amounting to [100s] shall be paid to the king... That is called a royal highway which is always open, which no one can close or divert with walls he has erected, which leads into a city or fortress or castle or royal town. Ibid, p 109 'All highways are completely the concern of the king...'. This reference to 'all highways' was a considerable extension to the four highways mentioned in the (alleged) Laws of William I, see n 256.

${ }^{308}$ Downer, n 20, p 113 'If he [a freeman] kills anyone, he shall be outlawed, and all who desire justice shall pursue him with the hue and cry.'

${ }^{309}$ There is no reason to suppose that the position under Anglo-Saxon law had changed in this respect. Ibid, p 165 'If the plea is one of theft...capital punishment should be carried out with respect to all persons of manifest guilt.' Ibid, p 291 'With respect to an offender who has either confessed or is of manifest guilt, the proper course is to hand him over to the relatives of the slain man so that he may experience the mercy of those to whom he displayed none.' Also, pp 177, 179, 201, 293.

310 There is no reason to suppose that the position under Anglo-Saxon law had changed in this respect. See also Downer, n 20, p 291 'If anyone, either alone or in the company of others, slays a Frenchman for committing a theft while the latter is fleeing or resisting in the customary way, he shall at once make this public; and if this has become certain knowledge, he shall have peace for himself.' (italics supplied). This provision, since it extended to
} murdrum, must have applied generally.

${ }^{311}$ There is no reason to suppose that the position under Anglo-Saxon law had changed in this respect, see $\mathrm{n} 273$.

${ }^{312}$ See n 275. Downer, n 20, p 253 'Hamsocn occurs if anyone assaults another in his own house or the house of someone else with a band of men or pursues him so that he hits the door or the house with arrows or stones or produces a perceptible blow from any source. Hamsocn or hamfare is committed if anyone goes with premeditation to a house where he knows his enemy to be and attacks him there, whether he does this by day or by night.' ${ }^{313}$ Like Anglo-Saxon law, see $\mathrm{n} 231$, the Laws of Henry $I$ are not clear. However, they suggest a lesser penalty of forfeiture of the tongue. Downer, $\mathrm{n} 20$, p 141 'If anyone accuses another before a justice (and especially of matters for which a person, when convicted, would suffer capital punishment or injury to his honour), and the accusation is then revealed as a falsehood, he shall forfeit his tongue or redeem himself by payment of his wergeld'. Ibid, $\mathrm{p}$ 187 'Anyone who makes a false charge against his lord before the king or against any persons making accusations in respect of the more serious and criminal matters shall make amends by losing his tongue.'

314 Downer, n 20, p 259 'a man may fight against a person whom he finds with his wedded wife, after the second and third prohibition, behind closed doors or under the one covering, or with his daughter whom he begot on his wife, or with his sister who was legitimately born, or with his mother who was lawfully wedded to his father. Pecuniary compensation has however been provided by the laws if a married woman commits fornication and she is of the rank of ceorl or belongs to the six-hundred shilling class or the twelve-hundred- shilling class, and the physical mutilation has been prescribed for those persisting in the offence.' Cf. the (alleged) Laws of William I, see Robertson, n 18, p 269 'If a father finds his daughter in adultery in his own or in his son-in-law's house, he shall have full permission to slay the adulterer(s). Similarly if a son finds his mother in adultery during his father's lifetime, he shall have permission to slay the adulterer(s).'

${ }^{315}$ Downer, n 20, p 259. Ibid, p 273 'Any person may aid his lord without incurring a wite if anyone attacks him...however due consideration shall be given to the matter in all cases.' Ibid, p 257 'a man may join with his blood relative in every case of need.'

${ }^{316} \mathrm{Ibid}, \mathrm{p} 261$ 'If a quarrel arises as a sudden dispute between any persons because of an acrimonious exchange of words or any provocative occurrences, as a result of which any of them draws his sword from its scabbard, no one is obliged to wait passively until the swordsman strikes him.' Also, p 271 'If anyone in his own defence presents a spear or sword or any weapons against his enemy, and the latter, blinded by a detestable lust to inflict injury, rushes upon it, he shall bear responsibility himself for whatever happens to him.'

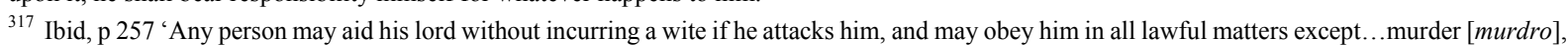
and similar offences, the commission of which has in absolutely no way been permitted, and which are branded as crimes by the laws.'

${ }^{318} \mathrm{P} \& \mathrm{M}, \mathrm{n} 88$, vol 2, p 483 suggest that blood money (wer) was payable even in the case where a man acted in self-defence. They cited as authority the Laws of Henry I, see Downer, n 20, p 267 'If anyone can establish by the ordeal of the hot iron or by battle or by production of lawful witnesses or oath 
Finally, the Laws of Henry I started to limit the right of private revenge (blood feud) providing:

If anyone from the other kindred takes vengeance on any person other than the wrongdoer himself, he shall be an enemy of the king and of all his kindred. ${ }^{319}$

However, it seems the blood feud was still permitted:

In the case of a person compelled by necessity to commit a slaying the wite will with justice remain unpayable, which is equally true of a person who commits a revenge slaying in a feud. ${ }^{320}$ (underlining provided)

Further, it seems that the victim's kin could still refuse compensation in the case of a killing. ${ }^{321}$ However, where it arose simply from accident (which included negligence and self-defence) - in practice (one would surmise) that the court put pressure on the kin to accept compensation. ${ }^{32}$

\section{(b) Assizes of Clarendon 1166 \& Northampton 1176}

It may be noted that - to help with the detection of murder - this Assize required sheriffs and county justices to hold inquiries into all murders in their counties and to name the alleged criminals and those who harboured them. ${ }^{323}$

- $\quad$ Further, to help identify such murders, representatives of the hundreds and villages were sworn on to local juries of presentment. They testified, under oath, to all crimes committed in their areas and named those responsible;

- The effect of this was to make the community (as opposed to the family) more responsible for bringing prosecutions. Doubtless, this increased the administration of the State in the criminal area as well as (probably) helped reduce the blood feud.

A later Assize of Northampton (1176) expressly provided that the assize was to present cases 'de murdro' (of murder). ${ }^{324}$

\section{In conclusion, the Laws of Henry I did not differ substantially from Anglo-Saxon law in respect of homicide.}

\section{Glanvill (c. 1189)}

The first text on English law - Glanvill, Treatise on the Laws and Customs of the Realm of England (c. 1189) - discussed criminal pleas, including homicide, which it declared was a plea of the crown. ${ }^{325}$ As to homicide, which was now punishable with death rather than, as in Anglo-Saxon times, compensable in accordance with a tariff, ${ }^{326}$ Glanvill stated:

There are two kinds of homicide. The first is called murder [murdrum]: this is done secretly, out of sight and knowledge of all but the killer and his accomplices, and so cannot be immediately followed by the hue and cry which is required by the relevant assize...There is another kind of homicide which in ordinary speech is called simple homicide [simplex homicidium]. ${ }^{32}$

Thus, Glanvill drew a distinction between murder and other forms of homicide.

helpers or by other suitable proof by ordeal that he was attacked and that he committed homicide under compulsion and in self-defence, he may establish this by also making honourable amends; and justice shall be done in the matter.' (italics supplied)

319 Downer, n 20, p 275. Ibid, p 259 'If anyone slays or injures in any way a person who offers to do justice he shall pay as amends the wite or compensation for the wound or for whatever he has done; and he shall lose whatever claim he had against him.' This suggests that, if the killer (other than in the case of premeditation) offered blood money to the victim's kin, it was not, thereafter, justifiable to kill him on the basis of the blood feud. JW Jeudwine, Tort, Crime and Police in Medieval Britain (1917), p 49 'As every murder was the possible opening for a local war of large dimensions occurring very likely at a time when the king or overlord wanted all his force for outside operations, every feud leaving behind it a bitter enmity which might revive untimely in the day of wanted co-operation, it was in the interest of the chief, not only financially but also politically, to bring about a settlement if it were possible. The knowledge of this fact made him and his most influential advisers anxious and ready to settle blood feuds.' Anglo-Saxon law does indicate prior attempts to reduce the blood feud, however, its continuance until the time of Henry I, seems clear. See Attenborough, n 18, 39 (Laws of Ine, 688-725), p 39 'If anyone exacts redress, before he pleads for justice, he shall give up what he has taken, and pay as much again, and 30 shillings compensation'. Also, p 47 (secret slaying of a thief). See also Holdsworth, n 65, vol 2, p 44 .

${ }^{320}$ Ibid, p 277.

${ }^{321}$ Ibid 'Justice must be done to the kindred of the slain man by the person presiding over the court, whether the wergeld due to them may or may not be accepted.'

${ }^{322}$ Not least since the court (Crown) would derive money (the wite) from this. Pressure would also have come from the church as well as from the community. See eg. RC Van Caenegem, English Lawsuits from William I to Richard I, SS, vol 106, pp 110-2 (c. 1070-1095, refusal of reconciliation in a case of homicide, in spite of Bishop Wulfstan's efforts, is punished with madness).

${ }^{323}$ W Stubbs, Select Charters and other Illustrations of English Constitutional History ( $9^{\text {th }}$ ed, 1870), pp167-73. It provided, inter alia, that 'an inquest shall be made throughout the separate counties, and throughout the separate hundreds, through twelve of the more lawful men of the hundred, and through four of the more lawful men of each township, upon oath that they will speak the truth: whether in their hundred or in their township there be any who... has been charged or published as being a robber or murderer (murdratorum) or thief.' Holdsworth, n 65, vol 1, p 71 'The Assize of Clarendon... reserved to the royal justices jurisdiction over the....murderer.' J Briggs et al, Crime and Punishment in England (1996), p 8 'By this means the community rather than the family became responsible for bringing prosecutions.'

324 Ibid, pp 178-81.

${ }^{325}$ Glanvill, The Treatise on the Laws and Customs of the Realm of England (c. 1189)(Nelson, 1965), pp 3, 174-5. Hudson, n 18, p 714 'Here for the first time...we have clear evidence that homicide was considered a plea of the crown to be tried only by the king or his justices, whether the accusation was brought by appeal or presentment. Estimates from thirteenth-century records have suggested an annual homicide rate per county of about ten to twenty, the largest proportion being caused by knives.' Yntema, n 267, p 146 'Homicide became a plea of the crown by way of the king's peace...the group of kindred had first to admit the king's claim to fortisfactura in special cases and to give up the feud in exchange for compensation. Ultimately, even this was absorbed by the royal prerogative of forfeiture: all that was left to the kindred in satisfaction of the ancient instinct of blood revenge was the appeal, which was again in course of time duly to be superceded by the plea of the crown.'

${ }^{326}$ Ibid, p 3.

327 Ibid, pp 174-5. 
- What is unclear is whether the reference to 'murdrum' was just to the murder fine (which was now imposed for killing Frenchmen or foreigners where the killer was unknown or where the killer was known but not produced within 7 days) or whether it also included premeditated killing;

- It may well be that Glanvill was drawing no distinction since the murder fine and premeditated killing were treated as one and the same and, indeed, if the murder fine dates from king Canute (see 9(f)(i)), it is possible that the murder fine was just another example of premeditated killing and had never had a separate description;

- If so, then Glanvill was simply distinguishing (and rightly) between premeditated killing (murdrum), leaving 'homicide' to cover all other killings (e.g. intentional but unpremeditated killing, accidental killing, negligent killing, excusable and justifiable killing).

Stephen thought Glanvill had probably done this, since he declared that Glanvill's statement:

would, if the definition of murdrum were omitted, constitute a remarkable anticipation of the later division of the crime into murder and manslaughter, and if 'nullo vidente, nullo sciente clam perpetratur' [perpetrated secretly, no one seeing, no one knowing] is meant merely as a description of the circumstances under which murder is usually committed, and not as a strict legal definition, the passage may still be considered in that light. ${ }^{328}$

However, as Maitland noted, Glanvill failed to mention the murder fine. Therefore, Stephen's supposition may be wrong. ${ }^{329}$ Reference may also be made to the Dialogue concerning the Exchequer (Dialogus de Scaccario) ${ }^{330}$ - which is thought to have been written c. 1189 by (possibly) Richard Fitznigel (also called Richard Fitzneal, c. 1130-98). ${ }^{331}$ It stated:

Murder [murdrum] strictly speaking, is the concealed death of a man at the hands of an unknown slayer. For murder means 'hidden' or 'secret.' 332

Fitznigel then went on to explain the murder fine. ${ }^{333}$ This would suggest that Stephen was correct and that 'murder' was an expression used to cover both premeditated killing and the murder fine.

In conclusion, in the time of Glanvill (1189), premeditated killing was still unatonable. International - but not premeditated - killing (as in the case of a brawl) was likely atonable, as under Anglo-Saxon law.

\section{Summary - Law to 1189}

While the Anglo-Saxon law of murder and manslaughter is interesting, by the time of Bracton (c.1240), English law had adopted a different approach. The tariff of payments disappeared, as did the concept of blood feud, and English law followed - to a greater extent - Roman law, as opposed to Old Testament law. The following may be noted by way of summary of the law up to 1189 :

- Intentional. Babylonian law bi-furcated intentional killing into: (a) premeditated; (b) unpremeditated. So did Old Testament law and Anglo-Saxon law. 'Premeditated' killing was plotted secretly in the heart. Examples of it were killing: (a) by sorcery; (b) with poison; (c) in an ambush; (d) with a prior grudge or hatred (malice). ${ }^{334}$ Premeditated killing was regarded as particularly heinous and merited the death penalty. Further, there was no right of sanctuary under Old Testament (and, likely, early Anglo-Saxon) law. The rationale for this severity was, likely, that no compensation could be paid since the killer had sought to avoid that very thing. Life for life applied;

- Accidental. Babylonian law drew little distinction between accidental and negligent killing, treating the latter as part of the former. ${ }^{335}$ Compensation was payable. Old Testament - and Anglo-Saxon - law did the same. This still prevailed by 1189 ;

- $\quad$ Justifiable. Here, no crime was committed. Babylonian law held that it was lawful to kill:

○ pursuant to due legal process;

○ pursuant to lawful revenge (the blood feud);

\footnotetext{
${ }^{328}$ Stephen, n 55, vol 1, p 28.

${ }^{329}$ Maitland, n 13, pp 306-7 'in Glanvill that the deed is done in secret is the one mark which distinguishes murdrum from homicidium simplex, for Glanvill says nothing about the murder fine and makes no distinction between Frenchman and Englishman. The only difference that he thinks fit to note in the treatment of the two crimes which he thus distinguishes, is what looks to us like a mere matter of procedure, namely that in the case of murder, only the nearest kinsmen of the slain can bring an appeal, while in the case of simple homicide the appeal may be brought by anyone who is related to the slain by blood or tenure, and who has been an eye witness of the deed. We should be rash in concluding that there was no other difference, for Glanvill's treatment of the subject is extremely meagre. His distinction is very much that taken in the Assizes of Jerusalem $\left[13^{\text {th }}\right.$ century legal treatises containing the laws of the crusader kingdoms of Jerusalem and Cyprus] and there we find this difference between murder and mere homicide the foundation of some very curious special pleading. However, this is all that Glanvill has to say.' See also P \& M, n 88, vol 2, p 486 and Reeves, n 221, vol 1, pp 198-9.

${ }^{330}$ See Richard, son of Nigel, The Course of the Exchequer (trans Johnson, Thomas Nelson, 1950). See also (for another translation) R Fitzneale, The Ancient Dialogue concerning the Exchequer (printed for J Worrall, 1758).

${ }^{331}$ Cf. P \& M, n 88, vol 1, pp 161-2.

332 Ibid, n 318, pp 52-3.

333 'In the period immediately following the Conquest what were left of the conquered English lay in ambush for the suspected and hated Normans and murdered them secretly in woods and unfrequented places as opportunity offered. Now when the kings and their ministers had for some years inflicted the most severe penalties on the English without effect, it was finally decided that the hundred in which a Norman was found killed, without his slayer being known or revealing his identity by flight, should be mulcted in a large sum of assayed silver, $£ 36$ or $£ 44$ according to the locality of the murder and the commonness of the crime. This is said to have been done for the security of travellers and to induce all men to make haste to punish such a crime or to deliver up to judgment the man by whose fault so great a loss injured the whole neighbourhood.' A fn indicates 'The legal authorities put the fine at 46 marks ( $£ 3014 \mathrm{~s} 4 \mathrm{~d}$ ). From 1130 to 1207 the amount gradually declined from twenty to two marks (Pipe Rolls).'

${ }^{334}$ Roman law also recognized a sub-division of intentional killing and that an absence of premeditation might reduce liability, see n 199.

${ }^{335}$ Roman law developed, to an extent, a third category - (c) negligent homicide. However, Anglo-Saxon law (following Old Testament law), generally treated this as an aspect of accidental killing, although there was a greater degree of separation in later Anglo-Saxon law.
} 
- a sorcerer, one who killed by witchcraft or poison;

- a perjurer, in a capital case;

- a housebreaker (a man breaking into one's house) ${ }^{336}$

○ a highway robber (brigand); ${ }^{337}$

- a thief, in most cases;

- an adulteress caught in the act (in flagrante).

Although Babylonian law did not expressly provide that it was lawful to kill the following, one assumes this would have been axiomatic:

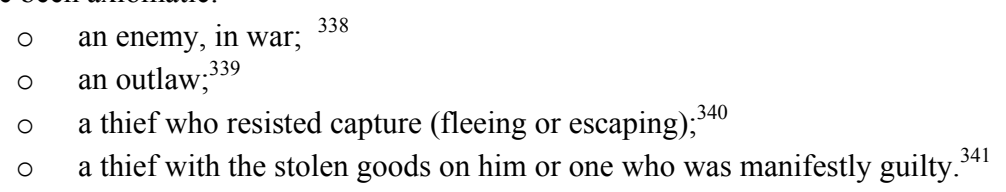

The only substantive change to the above which Old Testament and Anglo-Saxon law made (and up to 1189) appears to be that they restricted the justifiable killing of a burglar, to one who burgled at night (a night thief). ${ }^{342}$ And that, in the case of Anglo-Saxon law, a perjurer in a capital case (probably) only incurred the loss of his tongue - as opposed to being justifiably killed.

- Excusable All of Babylonian, Old Testament and Anglo-Saxon law (and up to 1189) made it excusable to kill a person:

$\bigcirc \quad$ in self defence;

in defence of one's kin;

$\circ \quad$ in defence of one's lord.

Why was Anglo-Saxon and, indeed, Old Testament law, so similar to Babylonian law? The answer is that all three were based on the lex talionis, which had received divine sanction. Further, it is remarkable how consistent this concept was in all three laws over such a long period of time. Was the Anglo-Saxon law on murder and homicide successful? At one level, it likely was, since fines for manslaughter were very large and this (probably) reduced the level of violence in Anglo-Saxon law, as well as any subsequent blood feud. However, there were problems with the Anglo-Saxon tariff, viz.

- the level of fines was so high that the system likely collapsed because no one was able to pay them;

- the system of blood feud (private revenge) conflicted with justice dispensed by the king. Thus, it was inevitable that the blood feud would disappear in due course. ${ }^{343}$ So too, the murder fine - not least since it became difficult to distinguish the nationality of a person due to intermarriage;

- $\quad$ all intentional killing should have merited the death penalty on the basis of the strict application of the lex talionis (life for life, eye for eye etc). However, imposing the death penalty for premeditated killing only was likely a concession to the violent time in which Anglo-Saxon people lived, as well as the need to conserve manpower. The problem was that, bi-furcating intentional killing into: (a) premeditated; and (b) unpremeditated, lacked justification when the blood feud system ended and the State took to itself all criminal jurisdiction in respect of homicide. Also, when a more civilised society required that all intentional killing be punished with death unless it fell within some clearly defined exception (such as provocation or self-defence) or a pardon was subsequently obtained from the king.

In conclusion, Anglo-Saxon law (which closely followed that of the Old Testament) was too closely allied to the lex talionis - and the blood feud to help enforce it - to survive, when the State assumed criminal jurisdiction over homicide.

\section{Bracton (c. 1240)}

In many ways, the law by the time of Bracton, made a 'clean break' from Anglo-Saxon law. Gone was the tariff. Further, there was greater clarity as to the legal nature of murder and other killing (manslaughter). This was likely due to the influence of Roman law, of which Bracton had considerable knowledge. Finally, Bracton gave a fairly extensive - and coherent explanation of the law on homicide (unlike Glanvill, for example).

\section{(a) Homicide}

Bracton used the term 'murder' to apply to the murder fine (abolished in 1340), see 9(f)). As to killing in general, he stated:

\footnotetext{
${ }^{336}$ Although Babylonian law did not expressly indicate a separate category of burglar (a night thief) it would have been covered by the crime of housebreaking, n 109.

337 See n 110. For Anglo-Saxon law, see n 252 (lie in an unhonoured grave).

${ }^{338}$ By Bracton, it had become (following St Augustine, see n 288), a reference to a 'just' war, see n 372.

339 This was likely implicit in Babylonian and Old Testament law, since such a person was subject to the blood feud. The concept of an outlaw bearing the wolf's head, is found in very early law. See, for example, Hittite law. Neufeld, n 146, p 11 'If anyone elopes with a woman [and] afterwards a rescuer follows them, if two or three men die, there shall be no compensation. 'Thou art a wolf."

${ }^{340}$ This was provided for in Roman law (see n 189) and Anglo-Saxon, law (see n 272). A killer or thief who fled would usually be treated as an outlaw.

341 The summary execution of 'hand having' and 'back bearing' thieves was provided for in Anglo-Saxon law.

342 Old Testament law expressly provided for it (n 174) and it also applied under Anglo-Saxon law (n 273).

${ }^{343}$ Sulzberger, $\mathrm{n} 98, \mathrm{p} 4$ 'The feeling which individuals had for their clan is gradually transferred to the state or kingdom, and it is seen that all the clans together constitute one great clan, which is called the state. When this point is reached the lex talionis dies a natural death.' See also Kenny, $\mathrm{n} 57$, pp $22-3$.
} 
Among other crimes there is a capital crime [called homicide], which partly concerns the king, whose peace is broken, and partly the private individual who is slain wickedly and in breach of the king's peace. Hence we must see what it is and why it is so called, its various kinds, and the punishment imposed.

Homicide is the slaying of man by man [Et est homicidium hominis occisio ab homine facta]. If it is done by an ox, a dog or some thing it will not properly be termed homicide. For it is called 'homicide' from 'homo' and 'caedo', 'caedis', 'man-killing', so to speak. ${ }^{344}$ (wording divided and underlining supplied)

This seems admirably clear. Homicide was the killing of one person by another. Bracton then analysed 4 ways in which a person might be killed (he took the categorisation from ecclesiastical law, Bracton, himself, being a cleric). ${ }^{345}$ Thus, a killing might be:

- $\quad$ accidental (casu); ${ }^{346}$

- intentional (voluntate);

- justifiable (ex justicia); ${ }^{347}$ or

- $\quad$ excusable (necessitate). ${ }^{348}$

Bracton made a welcome advance by separating out excusable killing (such as by way of self-defence) from accidental killing.

\section{(b) Accidental Killing}

Bracton stated:

By chance, as by misadventure, when one throws a stone at a bird or elsewhere and another passing by unexpectedly is struck and dies, or fells a tree and another is accidentally crushed beneath its fall and the like. But here we must distinguish whether he has been engaged in a proper [lawful] or an improper [unlawful] act. [rei licitae vel illictae] Improper, as where one has thrown a stone toward a place where men are accustomed to pass, or while one is chasing a horse or ox someone is trampled by the horse or ox and the like, here liability is imputed to him. $^{349}$

But if he was engaged in a lawful act, as where a master has flogged a pupil as a disciplinary measure ${ }^{350}$ or if [another is killed] when one was unloading hay from a cart or cutting down a tree or the like, and if he employed all the care that he could, that is, by looking about him and shouting out, not too tardily or in too low a voice but in good time and loudly, so that if there was anyone there, or approaching the place, he might flee and save himself, or in the case of the master by not exceeding mean and measure in the flogging of his pupil, liability is not imputed to him. ${ }^{351}$ But if he was engaged in a lawful act and did not employ due care, [rei licitae et non adhibuit diligentiam debitam] liability will be attributed to him. ${ }^{352}$ (wording divided, underlining and bold supplied)

Here, Bracton clearly distinguished between accidental killing and what was, later, to be termed negligent killing (without

\footnotetext{
${ }^{344}$ Bracton, n 22, vol 2, p 340. Crabb, n 83, pp 292-3 and Reeves, n 221, vol 2, pp 9-10 summarised Bracton on homicide and murder.

${ }^{345}$ Ibid. Bracton took his four categories from the Augustinian canonist Raymond of Pennafort (c. 1175-1275) who expounded them in his Summary concerning the Causes of Penance (Summa de Casibus or de Poenitentia, c. 1223-9). Bracton also referred to Roman law, to Justinian. Both these points were noted by N Hurnard, The King's Pardon for Homicide before AD 1307 (1969), p 70. See also F Schulz, Bracton and Raymond de Penafort (1945) LQR, vol 61, pp 286-92. See also GC Pastor, St Raymond of Pennafort (Granada, 2010). Bracton's four categories also accorded with the canonist Bernard of Pavia (Bernardus Papiensis, 1150-1213), see Whitman, n 289, p 227.

${ }^{346}$ Also called, 'by misadventure.' OED, n 82 (misadventure).'Ill luck, bad fortune.' Also, 'Homicide committed accidentally by a person doing a lawful act, without any intention of hurt.'

${ }^{347}$ Bracton, $\mathrm{n} 22, \mathrm{vol} 2, \mathrm{p} 340$ 'In the administration of justice, as when a judge or officer kills one lawfully found guilty. But if the homicide is done out of malice or from pleasure in the shedding of human blood [and] though the accused is lawfully slain, he who does the act commits a mortal sin because of his evil purpose. But if it is done from a love of justice, the judge does not sin in condemning him to death, nor in ordering an officer to slay him, nor does the officer sin if when sent by the judge he kills the condemned man. But both sin if they act in this way when proper legal procedures have not been observed.' Ibid. p 341 'The punishment for homicide committed by deed varies; for homicide committed in doing justice, with a proper and lawful intention, no punishment is to be inflicted.'

${ }^{348}$ Ibid. 'Of necessity, and here we must distinguish whether the necessity was avoidable or not; if avoidable and he could escape without slaying, he will then by guilty of homicide; if unavoidable, since he kills without pre-meditated hatred [odii meditatione] but with sorrow of heart, in order to save himself and his family, since he could not otherwise escape [danger], he is not liable to the penalty for homicide.'

${ }^{349}$ Ibid, p 384 '[Accidental homicide]... may be committed in many ways, as where one intending to cast a spear at a wild beast or does something of the sort, as where playing with a companion he has struck him in a thoughtless jest, or when he stood far off when he drew his bow or threw a stone he has struck a man he did not see, or where playing with a ball it has struck the hand of a barber he did not see so that he has cut another's throat, and thus has killed a man, not however with the intention of killing him; he ought to be absolved, because a crime is not committed unless the intention to injure exists. It is the will and purpose which mark maleficia...[Et voluntas et propositum distinguunt maleficia] In crimes the intention is regarded, not the result.' [In maleficiis autem spectatur voluntas et non exitus]. See also Stephen, $\mathrm{n} 55$, vol 3, $\mathrm{p} 33$. The barber example is from Roman law, Digest, $\mathrm{n}$ 182, bk 9.2 .11 quoting Ulpian's, Edict, bk 18. It is also useful to compare Bracton's analysis with old French coutumes, such as FRP Akehurst, The Coutumes de Beauvasis of Phillipe de Beaumanoir (Univ of Pennsylvania Press, 1992)(a text of 1283), 716 which indicated, for example, that when a person was killed in a game such as in a joust or couler (a ball game resembling rugby), it was an accident 'But it would be different if the players got angry during the game, so that the action came about because of the anger, for in such a case the person responsible would be punished: for as soon as there is anger, the game is over.'

${ }^{350}$ This followed Roman law. Digest, n 182, bk 9.2.6 quotes Paul (n 194), Edict, bk 22 'for excessive brutality on the part of a teacher is blameworthy.'

${ }^{351}$ Bracton, $\mathrm{n} 22, \mathrm{vol} 2, \mathrm{p} 438$ 'Nor is he liable who kills by misadventure, without intention and wish to kill, [non animo et voluntate occidendi] and is guilty neither of dolus nor culpa. ..who, that having been proved, is dealt with more leniently by grace of the prince.'

${ }_{352}$ Ibid, p 341. See also Stephen, n 55, vol 3, pp 32-3.
} 
'due care') although no meaningful distinction was taken at the time. ${ }^{353}$ However, Bracton added (unfortunately, in hindsight) another criterion - whether the act was lawful (licit) or not. Thus, he created various sub-categories:

$\begin{array}{lll}\text { - } & \text { accidental killing } & \text { - lawful activity (misadventure); } \\ \text { - } & \text { accidental killing } & \text { - unlawful activity; } \\ \text { - } & \text { negligent killing } & \text { - lawful activity; } \\ \text { - } & \text { negligent killing } & \text { - unlawful activity; } \\ \text { - } & \text { intentional killing } & \text { - lawful activity; } \\ \text { intional killing } & \text { - unlawful activity. }\end{array}$

Bracton took these concepts of 'unlawfulness' and 'due care' from ecclesiastical law. However, what was not thought out were the consequences of this criterion of unlawfulness in the legal context since, by Coke's time (and, indeed, before) lawyers were asserting that killing as a result of an accidental, but unlawful, act was murder - an excessively harsh interpretation. Finally, it may be noted that, in the case of accidental killing in a lawful activity, a pardon was necessary. ${ }^{354}$

In conclusion, Bracton's reference to an 'unlawful' (improper) act and to 'due care' introduced legal complexity which was unnecessary since the unlawful act and the killing were separate acts, with separate mens rea.

(c) Intentional Killing

Bracton referred to killing:

By intention, as where one in anger or hatred or for the sake of gain [causa lucri], deliberately and in a premeditated assault, [assultu praemeditato] has killed another wickedly [nequitur] or feloniously [in felonia] and in breach of the king's peace.

As to these terms:

- $\quad$ Premeditated Assault. As previously noted, the reference to premeditation was present in Anglo-Saxon law and derived from the Old Testament. If there was premeditation, the death penalty applied. The reference to 'premeditated assault' may have derived from the concept of way-laying (ambushing) a person and the specific offence of waylaying a person under Anglo-Saxon law, that of 'forsteal' (see 9(e)). ${ }^{356}$ However, 'assultus' was also the latin word for the Anglo-Norman battery (battre). Thus, Bracton may not have been referring to an Anglo-Saxon crime (which was committed without killing a person). Instead, he may only have been indicating that the assault/battery leading to the death must be premeditated. In this sense the word 'assault' was superfluous and, indeed, it dropped out of the later reference of legal writers to 'premeditated malice';

- $\quad$ Felony. Felonies constituted crimes resulting in the death penalty, of which premeditated killing was a prime example. ${ }^{357}$ In the context of homicide, reference to 'felony' was not really appropriate in the case of accidental or negligent homicide - nor in the case of self defence - since there was no intent to kill (which was the cause of the 'wickedness'). ${ }^{358}$ Therefore, the use of the word 'feloniously' (as a synonym for wickedly) in the context of homicide caused confusion; 359

\footnotetext{
${ }^{353}$ P \& M, n 88, vol 2, p 484 'we never hear of 'negligence' or of any similar standard of liability, though just once by the way we see a boy, who frightened a horse which threw and killed its rider, sent back to gaol pro stultitia sua.'

354 Ibid, p 479 'The man who commits homicide by misadventure or in self defence deserves but needs a pardon...'

355 Bracton, n 22, vol 2, p 341. Also, p 438 'He is slain without right if he is slain in pre-meditated assault [assultu praemeditato] and felony and with intent to kill, through anger and greed...And so if, thinking to strike a light blow, he has struck a heavy one and killed; he is liable.'

See also p 388 (example of an appeal that B, 'wickedly, feloniously, in a pre-meditated assault and against the king's peace...dealt ...C ....a mortal wound.'). Crabb, n 83, p 293 'Voluntary homicide [in the time of Bracton] was, when any one of certain knowledge, and by a pre-meditated assault, from anger, malice or gain, killed another, nequitur and in felonia, against the king's peace...'

356 See also P \& M, n 88, vol 2, pp 485, 468-9.

357. Baker, n 84, p 502 'If the wrong was particularly heinous, it was 'unemendable' and the wrongdoer suffered judgment to lose everything he had: his life, his lands, and his personal goods. Wrongs of this kind were called 'felonies', from an old French word (meaning wicked or treacherous) which seems to have originated in the feudal context. A felony was an act of such wickedness that it destroyed the bond between lord and man, so that the tenant's land was forfeited to the lord. By the thirteenth century the feudal connection had disappeared from the definition, but remained as a consequence; for the use of 'words of felony' in making an accusation of crime indicated an offence so serious that conviction would result in forfeiture of property and life or limb.' See also P \& M, n 88, vol 2, p 465.

358 Ibid, p 523 'The word 'felony' implied wickedness, and therefore ought not to have extended to blameless accident and misadventure. In the case of homicide, effect was given to this distinction through the use of pardons, but it had a much broader application. When crime and tort became separate, the essence of felony was identified as a forcible criminal act done with a guilty mind (mens rea), whereas evil intent ceased to be an element in trespass against the king's peace for civil purposes. Intent was difficult to try. But in drawing this distinction between criminal and civil wrongs the common lawyers were following the canonist teaching - traceable to St Augustine - that mental guilt was a necessary prerequisite of criminal punishment: rerum no facit nisi mens rea." See also Hudson, n 18, p 711. One would suggest that 'felony' in the sense of wickedness had a Biblical source. See, for example, the Book of Leviticus, see n 122 and references generally to wickedness and malice in the Bible, see EW Goodrick \& JR Kohlenberger III, The Strongest NIV Exhaustive Concordance (1999) (see references to wicked and malice).

${ }^{359} \mathrm{Ibid}$, 'In indictments for murder, 'malice aforethought' was laid expressly. In other indictments, the mens rea was held to be implicit in the word felonice (feloniously). What amounted to such an intent, however, could only arise upon the evidence, and therefore little is known of the thinking about criminal intention until Serjeants' Inn conferences began to be noted in the sixteenth century....'
} 
- Wickedly (Maliciously). The word 'wickedly' (maliciously) likely derived from the Old Testament, since killing where a person could be shown to have had a grudge (hatred in his heart) gave rise to a presumption of premeditation; 360

- Breach of King's Peace. The ambits of legal jurisdiction in the case of Anglo-Saxon kings was limited since England was not unified and, in practice, the resolution of 'criminal' matters would have been handled at a local level. However, by the time of Henry I (1100-35) his criminal jurisdiction was being asserted over the whole country. And, by Glanvill's time (c.1189) (see 11), the king was asserting jurisdiction over all forms of homicide. ${ }^{361}$ Thus, Bracton could have just as well referred to the king's 'criminal law' as to the 'king's peace' in this context.

Why did Bracton add the words in 'anger or hatred or for the sake of gain...in a premeditated assault' since all intentional killing (unlike in Anglo-Saxon times) merited death? Pollock and Maitland state:

Every homicide that is neither justifiable nor yet excusable as a result of misadventure or self defence, is in Bracton's age felonious; also it is conceived as having been perpetrated by 'premeditated assault' or by 'malice aforethought'; also it earns the punishment of death...we may say that our law knows but one degree of criminal homicide; it does not yet know the line that will divide 'murder' from 'manslaughter.' 362

However, this does not really answer the question. An answer would seem possible, though:

- In Anglo-Saxon (and Old Testament) law, premeditated killing resulted in the death penalty without exception because it was so heinous. Thus, no payment of compensation (blood money) was possible. However, where the killing was intentional but unpremeditated - such as in the case of a brawl - blood money could be paid. By the time of Glanvill (c.1189), although the Anglo-Saxon tariff (the system of compensation) was becoming redundant, this distinction was preserved, but in a different way. In the case of premeditated killing there was (probably), no prospect of pardon. ${ }^{363}$ Thus, the concept of blood money not being sufficient was preserved, in that - although compensation was no longer paid, a pardon was not given when it was premeditated. It was too heinous;

- By the time of Bracton (c. 1240), all intentional killing was a felony and so the death penalty applied both to premeditated and unpremeditated killing (unlike in Anglo-Saxon times and that of Glanvill). However, one would suggest that a distinction was still preserved in that a pardon would only rarely be given when the killing was premeditated, whereas it would be much more likely to be given in the case of unpremeditated killing; ${ }^{364}$

- This distinction began to break down after Bracton since it seems clear from Acts in 1328 and 1389 (see 18 and 19), that kings - anxious to get money in to the treasury (or do political favours) - were prepared to dole out pardons even in the case of premeditated killing.

In hindsight, in the time of Bracton, it would have been useful to have called all intentional killing 'murder' which merited death, with no pardon permitted where premeditated. However, 'murder' was still connected to the murder fine (see 9(f)). Thus, there was no composite word for intentional killing. Also, kings in that time being anxious to assert their prerogatives, would likely have bridled at the idea that - even in the case of premeditated killing - they could not grant a pardon (albeit, exceptionally). This bi-furcation was to continue to bedevil the law for a long (long) time.

\section{(d) Justifiable Killing}

Bracton indicated that no crime was committed in the following cases, when a person killed:

- $\quad$ pursuant to due legal process; 365

- $\quad$ an outlaw (probably, in Bracton's time, only if resisting arrest); ${ }^{366}$

- $\quad$ a thief with the stolen goods on him; ${ }^{367}$

- a manifest felon (included a thief or robber) who resisted capture; ${ }^{368}$

\footnotetext{
${ }^{360}$ See $\mathrm{n} 122$. OED, n 82 (malice) F[rench] malice (recorded from the $12^{\text {th }}$ century). L[atin] malitia. 1. Bad quality, badness; chiefly in moral sense, wickedness (obs)...4. The desire to injure another person: active ill will or hatred.' See also P \& M, n 88, vol 2, p 469.

${ }^{361}$ See $\mathrm{n} 325$. However, the king sometimes franchised out criminal jurisdiction.

${ }^{362} \mathrm{P} \& \mathrm{M}, \mathrm{n} 88$, vol 2, p 485.

${ }^{363}$ This is not wholly clear since the source material is so scant. However, if given, it would likely be in rare circumstances.

${ }^{364}$ Whereas in the Old Testament sanctuary was not given for pre-meditated killing, it seems likely that, in later Anglo-Saxon law (at least) it was given and this also prevailed in the time of Bracton.

${ }^{365}$ Bracton, n 22, vol 2, p 340 'In the administration of justice, as when a judge or officer kills one lawfully found guilty.' See also P \& M, n 88, vol 2, p 478 'In a few cases homicide is absolutely justifiable and he who commits it will suffer no ill.'

${ }^{366}$ Bracton, $\mathrm{n} 22$, vol 2, p 354 'they bear the wolf's head and in consequence perish without judicial inquiry. This is so if they take flight or resist when they are to be arrested; if they are arrested alive or give themselves up, their life and death will be in the hands of the lord king.' See also pp 362, $363,378$. Cf. P \& M, n 88, vol 2, pp 476 \& 478 'slaying of an outlaw.' Cf. Reeves, n 221, vol 2, pp 20-1, vol 3, p 121 who thought that, by the time of Bracton an outlaw could only be killed summarily if he resisted arrest or returned without the king's pardon and that 'if he made no attempt to fly, his death would be punished as that of any other man.' See also Green, n 94, p 438 'By the thirteenth century, most localities were no longer allowed to execute captured outlaws and manifest felons without trial; that custom had become, by and large, frontier law.'

${ }^{367}$ Bracton, $\mathrm{n} 22$, vol 2, p 425 'Manifest theft is where a thief is apprehended seised of the stolen property, that is, hand having and back bearing...' Also, p 346. See also P \& M, n 88, vol 2, p 478 'slaying of... a hand-having thief.' The Anglo-Saxon expressions 'handhaving' (stolen goods in the hand) and 'backbearing' (stolen goods on the back) were covered by the Anglo-Norman word, 'manour'. See also Green, n 94, p 436, n 85.

${ }^{368}$ Although Bracton does not appear to expressly state this ( $\operatorname{see} \mathrm{n} 22$, vol 2, p 350 'Of criminals who flee immediately after a felony'), he treated a person, where the hue and cry was raised as being arrested ('the malefactor is, so to speak, arrested'). P \& M, n 88, vol 2, p 478 state that justifiable killing included the 'slaying of...other manifest felon who resists capture.' They also mention a case in 1272 where one who beheaded a fleeing robber was
} 
- $\quad$ a night thief; ${ }^{369}$

- a housebreaker, ${ }^{370}$

- a perjurer (one bearing false witness in a capital case) $;^{371}$

- $\quad$ an enemy, in a just war. ${ }^{372}$

In the case of a thief or a burglar, it was lawful to kill the same if the victim could not otherwise escape danger. Bracton stated:

he who kills a thief, either a day thief or a night thief, is not liable, [that is], if he could not otherwise escape danger; if he could he is liable. ${ }^{373}$ (italics supplied)

So too, with the killing of a housebreaker. It was now treated more as a case of excusable homicide (self defence) where a pardon was required. This seems to have been a tightening up of the law since, previously, killing such persons would probably have been justifiable even if there was no danger to the victim. ${ }^{374}$ Bracton did not deal (it seems) with the issue of whether:

- $\quad$ sorcerers (those who killed by witchoraft);

- $\quad$ poisoners; and

- $\quad$ adulterers caught in flagrante 375

could, justifiably, be put to death. One presumes not, and that this was an advance on Anglo-Saxon law.

In conclusion, justifiable homicide in the time of Bracton was - in most respects - the same as that under Anglo-Saxon law, save that burglars and housebreakers could only be killed if the killer could not otherwise escape danger (in effect, when self-defence applied). This likely applied to all felons, including thieves.

(e) Excusable Killing

In respect of killing due to necessity, Bracton stated:

we must distinguish whether the necessity was avoidable or not; if avoidable and he could escape without slaying, he will then be guilty of homicide; if unavoidable, since he kills without premeditated hatred but with sorrow of heart, in order to save himself and his family, since he could not otherwise escape [danger], he is not liable to the penalty for homicide. ${ }^{376}$ (wording underlined)

Thus, in Bracton's time, it was excusable to kill:

- $\quad$ in self defence;

acquitted. Ibid, n 4. See also Howel (1221) in Maitland, Select Pleas of the Crown, SS, vol 1, p 94 (H killed a robber who sought to kill him) and Leonin (1212), p 85 (foresters killed man stealing a deer who defended himself). In both cases they were acquitted. See also EJ Watson, Pleas of the Crown for the Hundred of Swineshead and the Township of Bristol (1902), pp 10-1. Bracton, n 22, vol 2, p 425 'a robber is a thief a fortiori, for who appropriates another's property more against the owner's will than he who seizes by force.'

${ }^{369}$ Bracton, n 22, vol 2, p 408 'If anyone slays a night thief, he will do so with impunity only if he could not spare him without danger to himself; if he could it will be otherwise.' See also Reeves, n 221, vol 2, p 11. For a case see The Roll of the Shropshire Eyre of 1256, SS, vol 96, p 213 'MG, an evildoer and thief, came to the barn of G... broke into and entered it, and stole from it...T was there keeping watch and he caught sight of her leaving the barn, but he could not tell for the darkness whether it was a man or a woman and he killed her as she fled. Since the testimony is that he killed her as a thief in flight, Thomas is quit.'

${ }^{370}$ Ibid, 'where one defends himself against hamsocn, which [the English call] the entering of a house in breach of the peace, and the intruder is slain, he will be free of liability if he who killed could defend himself in no other way.' P \& M, n 88, vol 2, p 478 'Bracton in his text would allow a man to slay a housebreaker, if to do so was necessary act of self-defence; but in his margin he noted a case of this kind in which the slayer was pardoned by the king.' See also Reeves, n 221, vol 2, p 11. Also, FW Maitland (ed), Pleas of the Crown for the County of Gloucester (1221), pp 85-6 \& 149 (R killed two (female) thieves when they were about to burgle a house and did it in self defence. It seems a pardon was required).

${ }^{371}$ Bracton appears to have said nothing on the matter. However, Britton (see n 414) and the Mirror of Justices (see $\mathrm{n} 416$ ), thought they should and one presumes that they were following Bracton on this (as they usually did). See also Reeves, n 221, vol 2, p 276 'perjury, if it had the effect of procuring a judgment of death, was punished with death.'

372 Bracton, $\mathrm{n} 22$, vol 2, p 342 'Homicide also occurs in war, and we must then ascertain whether the war is just or unjust. If it is unjust he who kills will be liable; if just, as a war in defence of the patria, he will not, unless he acts with evil intent'. In the time of Bracton, it was still possible to wage a 'private' war, as opposed to one in which the Crown was involved. Later, it became an axiom that only the sovereign could declare war and peace. See also Stephen, n 55, vol 1, p 32. Likely, Bracton took his concept of a just war from Raymond of Pennafort, see Pastor, n 345, App 2.

${ }^{373}$ Ibid, p 438. See also $\mathrm{n} 370$. This position reflects Roman law (Ulpian), see n 211.

${ }^{374} \mathrm{P} \& \mathrm{M}, \mathrm{n} 88, \mathrm{vol} 2, \mathrm{p} 479$ 'Altogether in our common law the sphere of justifiable homicide was very narrow, and the cases which fell within it were those which in old times would have been regarded less as cases of legitimate self-defence than as executions, for the fur manifestus had been ipso facto an outlaw.' As to why the law was tightening up, one would suggest that, by the time of Bracton, the courts were becoming more professional and legalistic, change to the 'rough and ready' system of justice which likely prevailed up to the $13^{\text {th }}$ century.

${ }^{375} \mathrm{Ibid}, \mathrm{p} 484$ 'There are signs that the outraged husband who found his wife in the act of adultery might no longer slay the guilty pair or either of them, but might emasculate the adulterer.' See also P \& M, n 88, vol 2, pp 552-6.

${ }^{376}$ Bracton, n 22, vol 2, pp 340-1. See also Crabb, n 83, p 292 'Homicide ex necessitate or se defendendo, was justifiable if the necessity was inevitable, as in defence of one's own person.' For early cases on excusable killing see Hurnard, n 345 , ch 3 . The right to self defence can be found in Continental legal systems at this time. See egg. JM Powell, The Liber Augustalis or the Constitutions of Melfi promulgated by the Emperor Frederick II for the Kingdom of Sicily in 1231 (Syracuse University Press, 1971), p 18 which also asserts the legal justification for this: 'The authority of the law of nations has introduced that each man should be permitted to protect his own body, and natural reason does not find this abhorrent.' The Constitutions also noted that (like English law) the principle extended to the protection of family members and to property, movable and immovable. Ibid, p 19. 
- $\quad$ to defend one's family; ${ }^{377}$

- $\quad$ to defend one's lord. 378

However, the necessity had to be absolute. ${ }^{379}$ Further, as with accidental homicide, a pardon was necessary - this was no justifiable killing where no crime was committed. ${ }^{380}$

\section{In conclusion, excusable homicide was the same as under Anglo-Saxon law.}

\section{(f) Murder Fine}

Bracton reserved the term 'murder' to cover the murder fine. ${ }^{381}$ This has been previously discussed. ${ }^{382}$ It may be noted that - by Bracton's time - premeditated (secret) killing and the murder fine were becoming more closely allied. ${ }^{383}$

\section{(g) Conclusion}

The categorisation of Bracton - in which he separated out excusable killing (self-defence) from accidental killing - was a welcome advance from Anglo-Saxon law and it was followed up to the time of Coke and beyond. However, in the light of the future history of murder and manslaughter, Bracton may be criticised as follows:

- $\quad$ Premeditated. The words 'assault', 'malice' and 'feloniously' added nothing in reality to the definition of premeditation and could have been dispensed with. Also, both premeditated and unpremeditated killing were felonies (i.e. the death penalty applied). Thus, it would have been more helpful if Bracton had indicated that premeditated killing merited no pardon, whereas unpremeditated killing (such as in a brawl or when committing an unlawful act) could be pardoned;

- Lawful/Unlawful. Bracton's sub-division of accidental killing into 'lawful' and 'unlawful' created confusion since he did not make it clear in what circumstances the latter should be treated as murder (premeditated) or manslaughter. Also, it was unnecessary;

- $\quad$ Accidental. It would have been helpful if Bracton had separated 'negligent' killing from 'accidental' killing. Also, accidental killing (when committed when there was no unlawful act) should not have required a pardon;

- Justifiable. It was not a crime to kill: (a) pursuant to due legal process; (b) an outlaw (if resisting arrest); (c) a thief with the goods on him; (d) a manifest felon (including a thief or robber) who resisted arrest; (e) a night thief; (f) a housebreaker; (g) (possibly) a perjurer in a capital case; and (h) an enemy in a just war. In the case of (e) and (f), however, the general proposition was that killing was only sanctioned when in self-defence ('without danger to himself'). Further, likely, (c) was treated as included in (b) or (d), so that such a person could probably only be summarily killed if he resisted arrest;

- $\quad$ Excusable. It was a defence to kill a person: (a) in self defence; (b) defending one's family (and servants); (c) defending one's master (lord). However, a pardon was required;

- $\quad$ Reckless. Reckless killing only developed in the $20^{\text {th }}$ century and it would have been too much to have expected Bracton to have developed it.

\footnotetext{
377 The reference of Bracton to 'his family' likely was based on the Roman 'paterfamilias' and, therefore, would have included not just immediate family but any slaves, servants and other members of his household. In Anglo-Saxon law, it was excusable homicide to defend one's kin, see $\mathrm{n} 279$.

${ }^{378}$ P \& M, n 88, vol 2, p 484 'a man might 'without felony' slay in defence of his own life or that of his wife or of his lord or of any member of his household.'

${ }^{379}$ Reeves, n 221, vol 2, p 10 'Homicide by necessity was, when it was inevitably necessary to kill the party, in order to defend one's person and property; for if the necessity was not inevitable, the fact was accompanied with the guilt of homicide.'

${ }^{380} \mathrm{P} \& \mathrm{M}, \mathrm{n} 88$, vol 2, p 479, n 2 'We do not think that in the thirteenth century a homicide in self-defence would have been justifiable, even though it was perpetrated in the endeavour to prevent a felony.' They cite as an example where a woman killed a man seeking to rape her; a fine was paid by her father to return to the peace.' See also Ibid, p 480.

${ }^{381}$ Bracton, n 22, vol 2, pp 378-9 'We have spoken above of homicide committed openly and in the presence of many bystanders. Now we must turn to homicide committed in secret, in no one's presence, to no one's knowledge, and in no one's sight or hearing, which is called murder. First we must see what murder is, why it was devised, and how one may be discharged [payment] of a murder fine. Murder is the secret slaying of a man by the hand of man [whether those slain are known or strangers, committed wickedly] done out of the sight of and unknown to all except the slayer alone and his accomplices and abettors so that no public hue and cry immediately pursues them, and [where] who the slayer is cannot be ascertained. The word 'secret' is used because the slayer is unknown; 'of man', so as to include male and female and exclude brute animals lacking reason. I say 'of strangers and men who are known' because whether the slain man is known or unknown he is called a Frenchman, unless englishry, that is, that he is an Englishman, is presented before the justices [and] proved by his kinsmen.' Also, 'He will always be reputed a Frenchman unless it can be shown that he is English, englishry having been properly presented before the justices... The words 'by the hand of man' are used to distinguish it from the case of those slain or devoured by beasts and animals which lack reason; such persons cannot be said to be murdered feloniously since animals which lack reason cannot be said to commit injuria or felony. Or the words may be used to distinguish it from the case of those who have died by misadventure, as they drowned, crushed and the like; by misadventure where there is no concealed felony, as will be explained below.' See also Stephen, $\mathrm{n} 55$, vol 1 , pp 29-33.

${ }^{382}$ See also Maitland, n 13, p 307 'Bracton repeats Glanvill's distinction, but immediately blurs and probably perverts it by mentioning the murder fine. Murder, he says, is secret homicide, for the slayer is unknown. By this he means that were the slayer known and produced there would be no murder fine, no murdrum. From this we may conjecture that the word had already lost the sense attributed to it by Glanvill, namely, that of manslaughter done in secret. When, therefore, in 1340, it was set free from the very technical and peculiar sense given to it by the practice of fining the hundred, it did not apparently ever regain its oldest meaning, but came in course of time to signify a manslaughter [homicide] by what was called malice prepense.' See also Maitland, $\mathrm{n}$ 371, $\mathrm{p}$ xxix who noted that, in these pleas: 'The word murder is never used to differentiate two degrees of homicidal guilt, it merely means that the slayer has not been caught and that englishry has not been presented.'

${ }^{383}$ Indeed, when Bracton, n 22, vol 2, p 327 discussed what a judge of eyre should do to describe to the people his function, he suggested they commence, 'First of all, of the king's peace and justice and the breaches thereof by murderers [murdritores], robbers etc.'
} 


\section{(h) Ecclesiastical Influence}

As previously noted, Bracton's statements on homicide were largely taken from the cleric Raymond of Pennafort (c.1175-1275) and also reflected the views of the cleric Bernard of Pavia (1150-1213). ${ }^{384}$ It is also noteworthy that Thomas Aquinas (1225-74) in his Summa Theologiae (written c. 1263-73) made a number of statements about homicide which reflected similar views to these clerics and which, doubtless, influenced (in a moral sense) judges after Bracton. In particular, the following may be noted:

- $\quad$ Killing - Legal Process. Aquinas indicated that the public authority could execute malefactors (criminals) but not private persons; ${ }^{38}$

- Self Defence. Aquinas argued that the controlled use of counter-violence constituted legitimate self defence, following the Decretals of Gregory IX (c. 1234), a canonical collection formed by Raymond of Pennafort at the request of the pope; ${ }^{386}$

- Chastisement. Aquinas argued that it was legitimate for fathers to beat their sons and masters their slaves (servants) by way of discipline. However, this only covered beating ${ }^{387}$ and not other means of inflicting injury. Further, such beating was not to be disproportionate and 'irreparable harm' (such as killing) was not permitted, ${ }^{38}$

- $\quad$ Accidents - Lawful \& Unlawful. Aquinas stated:

In Aristotle's definition, chance is a cause that acts without a personal agent intending it. ${ }^{389}$ Simply speaking, therefore, accidental happenings are neither intended nor voluntary. And because every sin is, as Augustine says, voluntary, it follows that accidents as such cannot constitute sins. ${ }^{390}$

What is not willed or intended as such may nevertheless be incidentally willed or intended. We may incidentally cause something by removing the obstacle against the thing happening. It follows that somebody who does not remove such occasions of homicide as he could and should remove will in some way be guilty of voluntary homicide.

This can come about in two ways - when a person engages in nefarious (illicit, rebus illicitis) activities which he should not have engaged in, or when he does not take due care. [i.e. negligent] This is why the law lays down that if a man engages in legitimate activities and uses due care, he is not guilty of any homicide that may ensure; if, on the other hand, he engages in illicit activities, or even fails to take due care in some legitimate enterprise, he is guilty of any homicide that may occur. (underlining supplied) ${ }^{391}$

This analysis of Aquinas was no different to that of Bracton who had incorporated the writings of Raymond of Pennafort into his work and it reflected the ecclesiastical view of that time.

In conclusion, the writings of Bracton were hugely influential up to the time of Coke and beyond. However, his wholesale adoption of ecclesiastical law in respect of the law of homicide, brought mixed blessings. It made a welcome advance in separating excusable killing (such as by way of self-defence) from accidental killing. ${ }^{32}$ However, it promoted a legal fiction in respect of unlawful acts which the law on manslaughter has still not rid itself of.

\section{Statute of Marlborough 1267}

It seems clear that - at some stage, pre 1240 - the murder fine was being (illegitimately) extended to cover accidental deaths. $^{393}$ Thus, this Act provided:

\footnotetext{
${ }^{384}$ See n 345. See also Blom-Cooper, n 69, p 25.

${ }^{385}$ T Aquinas, Summa Theologiae (Cambridge UP, 2006), vol 38 (Injustice), p 27 'the care of the whole community has been entrusted to the rulers who exercise public authority, and so it is only they, and not private persons, who may execute malefactors.' Ibid. p 37 'What is done according to due process of law (secundum ordinem justiciae) is not sinful.' Also, p 39 'the executioner commits no sin by obeying the order...'

${ }^{386}$ Ibid, p 43 'the controlled use of counter-violence constitutes legitimate self-defence, for according to the law it is legitimate to answer force with force provided it goes no further than due defence requires. Moreover a person is not obliged under pain of loss of eternal life to renounce the use of proportionate counter-force in order to avoid killing another, for a man is under a greater obligation to care for his life than for another's.' Aquinas cited Decretals of Gregory IX (c.1230), vv, 12, 18.

${ }^{387}$ Ibid, p 53 'A beating causes a certain damage to the body...but not in the same way as mutilation does... beating only causes him [the victim] pain'. This was very similar to Old Testament law, where only a rod was permitted.

${ }^{388}$ Ibid, p 55 'What the prohibition on fathers provoking their sons to anger [Book of Ephesians, ch 6, vv 4 \& 9] excludes is not their beating them in the interests of discipline, but any disproportionate beating... their coercive power, therefore, covers minor penalties which do not inflict irreparable harm.'

389 Ibid, p 45. The reference is to Aristotle, see R Waterfield, Aristotle, Physics (OUP, 1996), bk 2. 6.

390 Ibid. The reference is to Augustine, De Vera Religione (Of True Religion), 14 PL 34, 133.

391 Aquinas continued, p 47 'Hence. 1. Lamech failed to take sufficient care to avoid homicide, and therefore incurred the guilt of homicide. 2. A person who strikes a pregnant woman is doing something wrong, so that if either the woman or the foetus dies as a result, he will be guilty of the crime of homicide, especially since it is so clear that death may result from such a blow. 3 . The canons impose penalties penalties on those who take another's lives accidentally in the course of doing something illicit or of not taking sufficient care.' For Lamech, see the Book of Genesis, ch 4, v 23.

${ }^{392}$ Unfortunately, it left the Biblical 'horror' of spilling blood (see $n$ 137) extant by failing to assert that accidental and excusable killing were not crimes (like justifiable killing), with a result that a pardon was still required for them (to prevent imprisonment and forfeiture), causing unnecessary administration. By Blackstone's time (1765-9) this was being ignored and an acquittal granted. However, forfeiture for this was not abolished until 1828 . ${ }^{393} \mathrm{P} \& \mathrm{M}, \mathrm{n} 88$, vol 2, p 487 'In some counties a murdrum was exacted by custom in case of accidental death; Bracton regarded this as an abuse...[see Bracton, n 22, vol 2, p 380].' See also, p 482 and Maitland, n 13, p 305. See also Plucknett, n 221, p 445 and Coke, n 44 , vol 2, p 148. This Act was misinterpreted by Coke (ibid) and others to support the idea that a man, prior to this Act of 1267, who killed another in self defence or by accident was hanged, something Pollock and Maitland (as with others) pointed out was quite incorrect (Coke's analysis of the Old Testament law was also incorrect). See also P \& M, n 88, vol 2, pp 481-2 and Maitland, n 13, p 305.
} 
Murder [murdrum] from henceforth shall not be judged before our justices, where it is found misfortune [accident] only, but it shall take place in such as are slain by felony, and not otherwise. ${ }^{394}$

Thus, this Act sought to limit the scope of the murder fine to what it had originally been. As for the term 'malice prepense' (malice aforethought, premeditated malice), the following may be noted:

- Maitland thought this had, likely, become a legal term by 1270 (if not before) and that it was contrasted with sudden anger. ${ }^{395}$ Also, Maitland thought that the word 'malice' was a foreshortening of a reference to waylaying or other examples of premeditation. ${ }^{396}$ This would seem a reasonable supposition, save that - as Maitland also accepted - premeditated malice existed from Anglo-Saxon times (indeed, to the time of the Old Testament) ${ }^{397}$ and, that the word 'malice' was used simply to 'swell' the charge; 398

- In short, over time, murder changed from being described as an act of premeditated waylaying (ambush) or premeditated assault (battery) to being described as an act of 'premeditated malice.' That is, the intent behind the act was accentuated, as opposed to the act as such. However, despite all the nomenclature the substantive requirement of 'premeditation' (plotting) never changed.

\section{In conclusion, this Act of 1267 confirmed that the murder fine was not to be levied in the case of accidental killing.}

\section{Statute of Gloucester 1278}

Plucknett noted:

In the thirteenth century misadventure [accident] and self-defence were still recognised, not so much as defences to a charge of homicide as circumstances entitling one to a pardon; but if these defences were not involved, there was but one other case, and that was homicide. Whatever might be urged in mitigation of this offence could only be urged before the king as part of an appeal for pardon; it could not be considered by a court of law. ${ }^{399}$ (underlining supplied)

The problem with not treating these as defences was that it took a long time to secure a pardon, with the result that many people languished in prison. ${ }^{400}$ To speed up the process of securing a pardon, ${ }^{401}$ the Statute of Gloucester 1278 , ch 9 provided: ${ }^{402}$

The king [Edward I, 1272-1307] commandeth that no writ shall be granted out of the chancery for the death of a man to enquire whether a man did kill another by misfortune [misadventure], or in his own defence, or in any other manner without felony; ${ }^{403}$ but he shall be put in prison until the coming of the justices of eyre, or justices assigned to the goal delivery, and shall put himself upon the country before them for good and evil: in case it be found by the country, that he did it in his defence, or by misfortune, then by the report of the justices to the king, the king shall take him to his grace, [i.e. pardon him] if it please him. ${ }^{404}$ (underlining supplied)

The effect of this Act helped make clearer the distinction between killing by accident or in self defence - for which a pardon would usually be given as a matter of course ${ }^{405}$ - and intentional killing, where a pardon would be rare, especially so where it was premeditated. ${ }^{406}$

\footnotetext{
39452 Hen III c 25 (rep) ('Murdrum de caetero non adjudicetur coram justiciariis, ubi infortunium tantummodo adjudicatum est, sed locum habeat murdrum de interfectis per feloniam tantum, et non aliter). Reeves, n 221, vol 2, p 77 'The fine called murder...tho' by the general law only due upon a secret felonious killing, yet, as appears from Bracton, was by the particular custom of some places exacted in other cases of homicide, and even in such as were not felonious. The object of this statute, therefore, was to abrogate such customs, and reduce the whole law of the realm to a uniformity. This is very different from the opinion of those who imagined that the murder here spoken of to signify the fact of killing; and that the statute ordained, that killing per infortunium should not be deemed felonious, or murder.' See also Stephen, n 55, vol 3, p 36.

${ }^{395}$ Maitland, n 13, pp 308-9. See also Kaye, n 22. This text (written c. 1275), p 5 cited an appeal for murder that X ' feloniously as a felon and intending to kill' Y stabbed him with a sword and Y died ('felonessement com felon et en entente de li occir'). Also, p 19, X 'felonously as a felon and in a premeditated attack tried to kill' Y ('felonessement com felon en assaut purpense me voleit aver occis.').

${ }^{396}$ Ibid, p 323 . Also, p 325 'Some premeditation is of its essence, and the notion of waylaying or ambush is giving way to that of spite or malevolence.'

${ }^{397}$ Maitland, n 13.

398 Ibid, p 323 'generalising crescendo as is at all times dear to the draftsman.'

399 Plucknett, n 221, p 445.

${ }^{400}$ Coke, n 44, vol 1, p 315 'Before the making of this statute, for that men were detained long in prison before they were called to answer, which was ever odious in law, writs de odio et atia issued out of the chancery for their relief....specially where the fact was either by misadventure, or se defendendo; and therefore this act restraining those writs, does prescribe a course for their speedy calling to answer in those cases.' Cf. P \& M, n 88, vol 2, p 481 'We are not persuaded by the commentators that this statute had anything to do with the writ de odio et atia.'

${ }^{401}$ P \& M, n 88, vol 2, p 481 suggest that the effect of this Act may have, actually, been to keep in prison persons who might have otherwise obtained a speedier pardon. However, it seems clear that, at least, the intent of the Act was to speed things up.

402 Plucknett, n 221, p 445 'By the Statute of Gloucester, 6 Edw 1, c 9 (1278), it was enacted that there should be no need in the future to get a special writ from chancery authorising an inquest, but trial judges at goal delivery should ask the jury if the homicide was accidental or in self-defence; 'then the justices shall inform the king, and the king shall give him grace, if he pleases." Baker, n 84, p 529 'after 1278 the trial judge could report cases of misadventure or self-defence to the king without the need for a special commission of enquiry. But the blameless killer still in theory incurred a forfeiture, because his act was considered a tort or 'contempt' to the king in depriving him of a subject.'

403 Stephen, $\mathrm{n} 55$, vol 1, p 36, fn 1 asserted the wording should be 'in other manner by felony'.

4041 Stat Glou. c 9. Stephen, n 55, vol 3, p 37 'the necessity for a pardon shows that some degree of guilt was supposed to be attached to killing by misadventure or in self defence.' See also Holdsworth, n 65, vol 3, p 312.

${ }^{405}$ Reeves, n 221, vol 2, p 153 ''It had before been a matter almost of course to grant pardons in homicide se defendendo, and by misadventure; which merciful usage, therefore, was only confirmed and secured to the subject by this statute.'

${ }^{406}$ Maitland, n 13, pp 304-5. See also, Stephen, n 55, vol 3, pp 36-41.
} 


\section{Britton, Fleta \& Mirror of Justices (c. 1290)}

Some fifty years after Bracton wrote, three other legal texts considered the law of homicide. However, they closely followed Bracton vis-à-vis homicide and, therefore, changed little, save on some smaller matters. These texts are now considered.

\section{(a) Fleta (c. 1290)}

Fleta closely followed Bracton, ${ }^{407}$ especially with respect to Bracton's categorisation of killing into: (a) accidental; ${ }^{408}$ (b) intentional; (c) justifiable; (d) excusable. ${ }^{409}$ As to (b), Fleta stated:

Homicide is the slaying of man by man with evil intent. ${ }^{410}$ Also, 'Wilfully, as for example, if a man, with corrupt intention, wickedly and feloniously slays anyone by a deliberate attack, in anger or hatred or for the sake of gain: and if this is done secretly [occulte] it will be accounted murder. ${ }^{411}$

Fleta also discussed the murder fine, stating:

Murder [murdrum] is the secret slaying of men, committed wickedly [nequitur] by men's hands, which is done in the knowledge and in the sight of none except the slayer and his accomplices and maintainers alone, so that the hue and cry will not straightaway be raised. And it is called murder because the slain man is reputed a foreigner unless englishry be presented in regard to him, when it may be ascertained that he was an Englishman by the production of his kinsmen. ${ }^{412}$

As can be seen, by comparing these two definitions, the distinction between the murder fine (murdrum) and what also now termed 'murder' (murdro) was very little. Thus, following Fleta:

(Murder Fine) 'Murder is the secret slaying of men, committed wickedly [nequitur] by men's hands...' (italics supplied)

(Homicide called Murder) 'if a man, with corrupt intention, wickedly [nequitur] and feloniously slays anyone by a deliberate attack... if this is done secretly...(italics supplied)

In both cases, the key word was 'secret' which was likely derived from the Anglo-Saxon distinction between 'secret' and 'open' killing - itself, reflecting the Old Testament distinction between premeditated and unpremeditated killing, a prime example of which was a person lying in wait to kill his enemy and then fleeing, in order to avoid the payment of compensation. Although the murder fine did not apply to Englishmen, it was inevitable these two concepts would, at some juncture, merge - which they did with the abolition of the murder fine in 1340 (see 18).

\section{(b) Britton (c.1290)}

Britton also referred to the murder fine ${ }^{413}$ but had little to say on it. However, like Fleta, he treated the murder fine and premeditated killing ${ }^{414}$ as virtually one and the same. Further, the examples Britton gave of premeditated killing are similar to those in Anglo-Saxon (and Old Testament) law, simply updated.

- Thus, Britton referred to: (a) colour of judgment through malice of the judge; (b) false (fake) physicians and surgeons; (c) poisoning; (d) perjury leading to the condemnation, and death, of a man;

\footnotetext{
${ }^{407}$ Stephen, n 55, vol 1, p 33 'Fleta copies and somewhat abridges Bracton.'

${ }^{408}$ Fleta, n 24, p 60 'By chance, for example by misfortune, as if a man should fell a tree which, in falling, crushed a passer-by or if a hunter should strike a man with a missile instead of the quarry. [see also, $\mathrm{p}$ 80]. Nevertheless, if a man sets about his business improperly, as, for example, if he should drive oxen fast and one of them, meeting a man, should slay him with his horns, the deed will be imputed to the driver because he did not exercise the diligence he should have done.' The reference is to negligence.

${ }^{409}$ Ibid. 'There may be slaying by necessity in two senses, for if the necessity were avoidable, without slaying, a man is guilty of homicide, whereas, should the necessity be unavoidable, he will not be liable to the penalty of homicide, because he has not slain feloniously, but from fear and instinctively, to save himself when he could not otherwise avoid his own death.' Fleta noted that necessary killing included killing an enemy in a just war. However, $\mathrm{p}$ 61 , 'He too, who slays in an unjust war, and likewise in a just war, if the intention is corrupt, commits homicide.' Also, 'Anyone... who slays a thief by night is not held to be a homicide, and he who slays a housebreaker, at least if he is defending himself or his household at the time, slays justly, and in the same way he who slays another to save himself from death.'

${ }^{410}$ Ibid. 'Homicidium est hominis occisio ab homine nequiter facta...'. Cf. JA Everard, Le Grand Coutumier de Normandie (Jersey \& Guernsey Law Review, 2009), p 284 'The suit for murder is made in this form: $\mathrm{R}$ complains of $\mathrm{T}$ that he murdered his father wickedly in the lord king's peace [nequiter in pace domini regis multrivit - meurdry son pere felonneusement en la paix de dieu]'. The Grand Coutumier was written c. 1254-8.

${ }^{411}$ Ibid. 'Voluntate, ut si quis animo corrupto in assultu premeditato, ira vel odio vel causa lucri, nequiter et in felonia aliquem interfecerit, quod si occulte fiat pro murdro habebitur.' (underlining supplied).

${ }^{412}$ It continued, $\mathrm{p} 78$ 'And whensoever it shall happen that murder is discovered in the countryside, the county will be amerced by the justices in eyre, unless grounds for discharge are brought forward. And if the body of anyone, dead in this fashion by felony or mischance, be buried before it has been viewed by the coroners and enquiry made concerning the circumstances of the death by the neighbouring tithings and townships in the county, the township will be in the king's mercy.'

${ }^{413}$ Britton, n 23, p 32 'Murder is the felonious killing of a person unknown, whereof it cannot be known by whom it was done. And our will is, that for every murder the hundred in which it shall be committed be amerced...And it shall not be adjudged murder, where any of the kin to the deceased can be found, who can prove that he was an Englishman and thus make presentment of englishery; nor, although the person killed was a foreigner, if he lived long enough to accuse the felons himself; nor where any felon shall be apprehended for the fact; nor in the case of accident or mischance; nor where any man shall have taken sanctuary for the felony; nor in the case where the felon shall be known, so that the felony may be punished by outlawry or otherwise attainted; nor where two or more persons have feloniously killed each other, although they be unknown or aliens.'

${ }^{414}$ Ibid, pp 29-30 'Let inquiry also be made of homicides and murders...And inasmuch as this felony may be committed under colour of judgment through malice of the judge, or under some other pretence, as by false physicians and bad surgeons, and by poison and sundry other ways, our pleasure is, that all those who have committed such secret felonies be indicted; and also those who falsely for hire, or in any other manner, have condemned, or caused to be condemned, any man to death by means of a false oath....If the prisoners are found guilty, let their judgment be death for death.' Also, $\mathrm{p} 506$ 'Perjury is a lie affirmed by oath.'
} 
- This reference to 'false physicians and surgeons' replaced reference to sorcerers of Anglo-Saxon times who, pretending to administer a salve, secretly kill their patient.

In all these cases, the killing is plotted (secret, premeditated). Thus, the death penalty applies.

\section{(c) Mirror of Justices (c.1290)}

This text also closely followed Bracton. ${ }^{415}$ Like Britton and the Mirror of Justices, it asserted that homicide could be committed by bearing false witness (perjury). ${ }^{416}$ It also referred to the murder fine. ${ }^{417}$

\section{In conclusion, these three texts added little (or nothing) to Bracton's statement of the law.}

\section{Statute of Trespassers in Parks 1293}

This Act ${ }^{418}$ provided that was a justifiable killing when a forester, parker or warrener killed a trespasser who would not yield themselves after hue and cry (i.e. if they resisted arrest). ${ }^{419}$ It provided:

To the intent that trespassers in forests, chases, parks, and warrens, may more warily fear hereafter to enter and trespass in the same...

if any forester, parker, or warrener shall find any trespasser wandering within his liberty, intending to do damage therein, and that will not yield themselves to the foresters, warreners, or parkers, after hue and cry made to stand unto the peace, but do continue their malice, and disobeying the king's peace, do flee, or defend themselves with force and arms; although such foresters, parkers, and warreners, or any other [coming in their company and aiding such foresters, parkers and warreners, in the king's peace, do kill any offender or offenders being so found, either in arresting or taking them, or any of them] they shall not be troubled upon the same before the king [and his justices, or before any other the king's bailiffs, or any other] within any franchise or without, nor shall lose for so doing either life or limb, or suffer any other punishment but shall enjoy the king's peace as they did before. (underlining supplied)

A proviso made it clear that no protection was granted to a forester who mis-used his power.

\section{In conclusion, this Act of 1293 established another category of justifiable killing.}

\section{Edward III (1327-77)}

In the reign of Edward III - although the general principles of Bracton prevailed ${ }^{420}$ - there were some important developments vis-à-vis homicide. The murder fine was abolished in 1340. Further, caselaw established additional grounds of justifiable homicide, to ensure the better administration of justice. ${ }^{421}$ These matters are now considered.

\section{(a) Statute of Northampton $\mathbf{1 3 2 8}$}

An Act in 1328 - the Statute of Northampton ${ }^{422}$ - called for restraint in the liberal use of pardons. ${ }^{423}$ It provided:

Whereas offenders have been greatly encouraged, because the charters of pardon have been so easily granted in times past, of manslaughters [homicides], robberies, felonies, and other trespasses against the peace it is ordained and enacted, that such charter shall not be granted, but only where the king may do it by his oath, that is to say, where a man slayeth another in his own defence, or by misfortune. (underlining supplied)

This Act, then, sought to limit pardons to accidental killing as well as in the case of self-defence. The need for such an Act indicates that kings had, likely, been profligate in granting pardons for intentional killing - including where it was premeditated. Hurnard argued that this profligacy can be traced to the decision of Edward I (1272-1307) in 1294 to grant

\footnotetext{
${ }^{415}$ Mirror, $\mathrm{n} 25, \mathrm{p} 22$, fn 1 notes this. Among other things, the Mirror stated that: 'Homicide is the killing of a man by a man [Homicide est occisio de homme par homme fete] .'

${ }^{416}$ Ibid, p 23 'homicides in will are also false jurors, false witnesses, and those who appeal others or defame them by indictment, or in other ways accuse persons falsely so that it is not their fault that death does not follow'. Also, where a person was tortured into falsely confessing a felony.

${ }^{417}$ Ibid, p 35 'If the person slain be unknown, then in such case it belongs to the coroners to enter a murdrum on their rolls, according to the statute of king Knut [Canute], made on setting out for Denmark, who, for the preservation of his Danes whom he left in England, ordained that whenever an unknown man was slain all the hundred should be in the mercy of the king under a judgment of murdrum.' A fn states 'This seems to come from Bracton... who took it from the so-called Leges Edwardi Confessoris [Laws of Edward the Confessor, see 9(f)].'

${ }^{418} 21$ Edw 1 (rep 1828). See also P \& M, n 88, vol 2, p 488.

${ }^{419}$ Stephen, $\mathrm{n} 55$, vol 3, pp 37-8 'foresters, parkers, or warreners, if they find trespassers who will not yield themselves 'after hue and cry made to stand unto the peace, but do continue their malice' are not to be troubled or punished if they kill any such trespasser in arresting him, but they are warned against acting maliciously.' This act supplies a case of homicide which was regarded as absolutely justifiable. The forester or park-keeper was not to be 'punished or disturbed' if he acted within the powers given by the act.' See also P \& M, n 88, vol 2, p 478.

${ }^{420}$ Reeves, $\mathrm{n} 221$, vol 3, p 118 'The ideas of homicide which prevailed in the time of Bracton, still seemed to govern'.

${ }^{421}$ This was likely a result of the state of lawless that the country was reduced to at times during Edward III's reign as a result of frequent wars, the Black Death (1346-53) and the general impoverishment of the country. For a useful article on what weapons were used to kill, location and motives, see BA Hanawalt, Violent Death in the Fourteenth and Early Fifteenth England, Comparative Studies in Society and History (July 1976), vol 18, no 3, pp 297-320. See also Green, n 94, pp 413-99.

422 Edw III c 2 (rep).

423 Plucknett, n 221, p 445 'It is important to remember that the prerogative of mercy was the only point at which our medieval criminal law was at all flexible; hence pardons were issued with liberality for all sorts of felonies throughout the middle ages and long afterwards, and it is the history of pardons, therefore, that the gradual growth of a classification of homicides is to be sought. A beginning was made in 1328 when a statute called in general terms, for restraint in issuing pardons...' See also Stephen, n 55, vol 3, p 38 (complaint on the Parliament Roll in 1310 as to the ease in which pardons were granted for homicides).
} 
pardons to criminals provided that they enlisted for his wars, ${ }^{424}$ something which also prevailed in the reign of Edward III $(1327-77) .{ }^{425}$

\section{(b) Abolition of Murder Fine - 1340}

In 1340, the murder fine was abolished. This simplified things in that the epithet 'murder' could then have been used to cover intentional killing and 'manslaughter' to cover accidental killing (where an unlawful activity was occurring) as well as to negligent killing and brawls. However, this did not occur. Further - and of no help to the speedy administration of justice accidental killing (where there was no unlawful activity) and excusable killing were not treated as defences. Instead, likely following the Old Testament perception of all killing being heinous, they were still treated as homicide, requiring a pardon. Stephen summarised the position:

The result of it [the abolition of the murder fine] was to cut away the ground of the distinction taken by Bracton between voluntary homicide in general and murder. The name ' $m u r d e r$ ', however, had no doubt come into common use, though the presentment of englishry had...come to be so antiquated and unfamiliar that fines on the county for the want of it were regarded as mere acts of oppression. The word murder therefore would naturally become the name of the worst kind of homicide.

Homicide would thus consist of (1) murder, indistinctly conceived of as the worst species of the offence; (2) homicide per infortunium [i.e. by accident] et se defendendo [and by way of self-defence], which, though blameable to some extent, involved no other consequences than expense in getting a pardon, forfeiture of goods, and imprisonment before trial; and (3) justifiable homicide, which entitled a man to be acquitted. The large number of cases of homicide which, without belonging to the very worst class of all, were neither justifiable nor cases of misfortune or self-defence, were distinguished by no particular name, but were capital felonies, though not called murders. ${ }^{426}$

Thus, 'murder' did not cover all intentional killing. There was still a distinction between whether it was premeditated or not. This was unhelpful for clarification of the law. ${ }^{427}$ In the reign of Edward III (1327-77) and later, there were also some useful Yearbook cases on killing - one's often cited by later legal writers. These are now considered.

\section{(c) Cases of Accidental Killing}

A case in 1329 was one of accident (a child killed during a sport) for which a pardon was granted. And a curious case in 1370 established that, where a man fell on his own knife during a brawl, it was a matter of accident/suicide.

- $\quad$ Case in $1329{ }^{428}$ (Death by Misadventure). A case from the Eyre of Northamptonshire (1329-30). Men were throwing stones at target. A boy of seven crossed the target, was hit, and died. The jury said that W did not kill the boy feloniously or maliciously nor by intent or will to harm him, but by mere chance the stone struck his head and caused his death. The pardon stated that $\mathrm{W}$ 'by mischance and not feloniously nor of malice aforethought' (nec ex animo seu voluntate nocendi eum) ${ }^{429}$ did slay the boy;

- $\quad$ Case in 1370 ${ }^{430}$ (Suicide) A man knocked another to the ground. Over hasty in seeking to stab his victim before he got up, he fell on the victim's knife. The court did not consider it a matter of self-defence but, rather, likely to be one of suicide (a rather curious conclusion).

\section{(d) Cases of Intentional Killing}

\footnotetext{
${ }^{424}$ Hurnard, n 345, pp 311-2 'until 1294 the number of pardons for demonstrably felonious homicide was small... The first general proclamation that recruits for Edward's wars would receive pardon as soon as they found mainpernors to guarantee that they would serve and later stand to right was made on 12 June 1294 in order to raise troops for Gascony.' Ibid, p 324, 'In 1328, when the king's [Edward III, 1327-77)] youth and situation again facilitated criticism of the prerogative, the Statute of Northampton...made another attempt at limiting pardons to excusable homicide.' See also J Bellamy, Crime and Public Order in England in the later Middle Ages (1973), pp 192-3.

${ }^{425}$ Ibid, pp 324-5, indicating Acts in 1330, 1336 and 1340 which sought to enforce the 1328 Act. Also, the complaint of Parliament in 1353.

${ }^{426}$ Stephen, n 55, vol 3, pp 40-1. See also P \& M, n 88, vol 2, p 488 and Holdsworth, n 65, vol 2, p 451.

${ }^{427}$ It may be noted that - at this time - both pre-meditated and intentional, but unpremeditated, killing were clergyable and there was a right of sanctuary. Thus, the only distinction between the two was that a pardon would have been more rare when the killing was premeditated.

${ }^{428} R v$ Woderove, see SS, vol 97, p 218. Also, AKR Kiralfy, A Source Book English Law (1957), p 25. Fitzherbert, n 30 , Corone, no 354 'It was found that a man killed a child by misadventure and also how he threw a stone that struck the child and so the justices remand him to prison to await the king's grace. He asked for bail but this was refused, but the sheriff was ordered not to put him in irons but to guard him in some other way. And the sheriff was ordered to show him such other favour as he could.' For an earlier case in 1212, see Hurnard, n 345, p 25. Such events were common. See also Green, n 94, pp 446-7. Cf. Laws of Henry I (c. 1113), p 279 'If anyone suffers any injury or mischief through the sudden discharge of a bow ...the person who set it up [here, who fired] shall pay amends.' Cf. Roman law, Digest, n 182, Bk 9.2.10 quoting Paul (n 194), Edict, bk 22 'For playing dangerous games is blameworthy conduct.'

429 The words 'feloniously nor of malice aforethought' accurately distinguished between intentional killing that was not premeditated and premeditated killing. Cf. a French coutume of 1282, Akehurst, n 349, p 710 'It sometimes happens that a man is at target practice with others, and as he looses his shot someone walks in front so that he is struck by the arrow and as a result he dies...In that case...the person firing the arrow should not be prosecuted nor should you make [private] war on him [i.e. apply the blood feud].' Cf. where a person was negligent, p 711 '[he] would be punished for his stupidity [sotie] according to the offense.'

${ }^{430} 44 \mathrm{Edw}$ 3, pl 55 fo 44a. Seipp no 1370.146. Seipp note: 'Note that one W. of Haleen was arraigned in the King's Bench, for this that he had killed J. of D. feloniously. He pleaded not guilty, and the jury (l'enquest) came and said that the deceased had struck W. again (aderer') in the head (le chiefe) with his fist, so that W. fell down on the ground, and when W. was on the ground, the deceased drew his knife to have killed W., and lying on the ground, W. drew his knife, and the deceased was so hasty to have killed W. that he fell upon the knife, and thus killed him (luy). Knyvet CJKB said that it he had killed the deceased, although he was defending himself, the chattels of W. would be forfeited, and the body of W. at the king's grace to have his charter of pardon, but it was found that the deceased had killed himself, so that the Court wanted to consider (adviser) if W. would be adjudged not guilty, if the chattels would be forfeited or not.'
} 
An important case in 1305 helped sound the death knell of the blood feud - the right to take private revenge. And, a case in 1328, established that killing could occur by way of omission (neglect) as well as by way of commission. A case in 1348 held that the killing of a third party peacemaker who intervened in a brawl was manslaughter.

- $\quad$ Case in $\mathbf{1 3 0 5}^{431}$ (Prohibiting Self Help). H had in his service one C (a lawyer) to whom he owed money. C stole a coat of his. $\mathrm{H}$ imprisoned him and, next day, took him to a gallows where he beheaded him without judgment. A sheriff was ordered to arrest $\mathrm{H}$ but could not locate him. H was outlawed;

- $\quad$ Case in $1328{ }^{432}$ (Murder by Neglect). A son exposed his sick father to cold weather, to hasten his death, which occurred;

- $\quad$ Case in $\mathbf{1 3 4 8}{ }^{433}$ (Manslaughter - Peacemaker killed). Two men were fighting. Another man sought to part them and was killed. This was a felony since, in accordance with the categorisation of Bracton, the parties were engaged in an unlawful act. ${ }^{434}$ This case is an important one since, in Tudor times, it was taken as the basis for different propositions viz. if the third party was killed in the course of a:

- duel, it was murder (by way of transferred malice);

○ brawl ('hot blood') it was also murder, being a killing arising from an intentional, unlawful, act.

\section{(e) Cases of Justifiable Killing}

Possibly, because of the widespread crime that existed in the era of Edward III and to extend the efficacy of the administration of justice, the courts re-inforced that it was justifiable to kill in certain circumstances. ${ }^{435}$ In such cases no pardon was required. ${ }^{436}$ Thus, it was justifiable for a person to kill:

- a felon resisting arrest;

- where robbers (and thieves) sought to kill a man;

- a burglar;

- a prisoner escaping. ${ }^{437}$

These exceptions had been stated by Bracton (see 13(d)), save in relation to a gaoler. A case in 1553 held that it was no longer justifiable to kill an outlaw.

- $\quad$ Case in 1329. ${ }^{438}$ (Felon refusing to Surrender). A case from the Eyre of Northamptonshire (1329-30). A thief and robber fleeing from the hue and cry, was killed (by decapitation). Since he was resisting lawful attachment and could be taken in no other way, it was held justifiable;

${ }^{431} R v$ Hawtrey (Yorkshire Eyre, 1305), see Kiralfy, n 428, pp 27-8.

4322 Edw 3, pl 1 fo 18b (1328). See Seipp no 1328.022. An indictment for homicide in the Queen's Bench. Seipp noted: 'One Thomas was indicted in the county of W. for this that he was supposed to have taken one Nicholas, his father, where he was sick, and carried him against his will (son gree \& sa volunte) from one vill to another; and the weather was cold (freide), so that the cold (freidure) and the carrying encouraged (exciteront) his death sooner than he should (have died). Thomas sued to cause the indictment to come before the king on the 15th of St. Hilary, and because it had not spoken of felony in the indictment, the Justices did not want to arraign him, but made him find good mainprise to have his body before the king on the 15 th of Easter, and in the meantime they wanted to send to the sheriff and to the coroners to certify if there was another indictment or not etc.'. See also Fitzherbert, $\mathrm{n} 30$, title Enditement, no 3.

43322 Edw 3 Lib Ass 71 fo 101a. Seipp no 1348.279ass. Seipp note 'Note, that one Tailour of S. was arraigned for the death of W. C. He said that he would tell the court the case as it was. There was a fight between his companion and him in the house of W., and the defendant wanted to have struck him with his knife. W. C. came between them to settle (appeaser) the fight, and the defendant struck him with his knife, not willing or knowing, so by misadventure. Thorp CJKB said that from the defendant's admission one had cause enough to adjudge him to death, because it was the law that if two persons fought together, and one came between them to settle (appeaser) the contest, and one or the other struck and killed him, he was guilty of this felony, because he began the wrong (le mal), and did it of his own wrong, and not by misadventure, but notwithstanding if he (ne) wanted to put himself on a jury (en pays), still the Court would receive him of grace. (latin begins) And he did so (latin ends). And he pleaded not guilty...' Reeves, $\mathrm{n} 221$, vol 3, p 120 'A killing, if in a quarrel or sudden affray, was equally felonious with any deliberate act of killing: it was so in Bracton's time, and so it still continued: therefore, where two men were fighting, and another interposing to part them was killed by one of them; to adjudge this felony, was perfectly consonant to the notions of law that had long prevailed.' See also Hale, n 45, vol 1, p 442. Cf. a French coutume of 1282, see Akehurst, n 349, pp 712-3 (in the same scenario 'the person striking the blow would be punished for the offence.'

${ }^{434}$ See also Statham, n 29, vol 1, p 435 and Fitzherbert, n 30, title Corone, nos 180, 262. For the position under earlier law, see Laws of Henry I (c. 1113), Downer, n 20, p 279 'If anyone, while he is endeavouring to separate persons fighting among themselves, is killed, though innocent, either intentionally or through the negligence of the disputants, the one who slew him shall pay amends for him, even though he did not start the quarrel.'

${ }^{435}$ Reeves, n 221, vol 3, p 120 'It was at the same time said, that a man might in many cases justify a killing; as, where thieves came to rob, or burglariously to break a house, they might safely be killed, if they could not be otherwise taken: the same of a gaoler, if he had a weapon in his hand, and was attacked by his prisoners: so that it should seem, the killing a thief or a burglar, if he could not otherwise be taken, was not homicide se defendendo, but justifiable. In reading our old writers on criminal law, it should be remembered, that they made a distinction between homicide se defendendo from necessity, and se defendendo justifiable; the former being felony, the latter none at all.'

${ }^{436}$ Ibid, pp 119-20 'when the killing happened in the execution of lawful process... here the defendant, instead of pleading not guilty, might state the special matter in the way of a justification; and if it was proved true, he went quit, without a charter of pardon. In such a case of justification, the jury were charged to find if the thief, against whom the process was directed, could have been otherwise taken: for so strictly did they require, even in justifiable homicide, that a plain necessity should be made out to warrant the killing.'

${ }^{437}$ Bracton did not mention this case. However, in his day, the death penalty applied to a prisoner who escaped from prison (even if later found innocent of a crime). Further, it would also have been a felony for a gaoler to let such a person escape. Thus, it is also likely that, even in Bracton's time, it would have been justifiable for a gaoler to kill an escaping prisoner, if necessity required. See also Britton, n 23, p 36 and GS McBain, Modernising the Law on Escape, Prison Breach and Rescue (2014), Review of European Studies, vol 6, no 4, pp 147-73.

${ }^{438}$ The Eyre of Northamptonshire, SS, vol 97, p 172. 
- $\quad$ Case in 1329. ${ }^{439}$ (Killing a Burglar). A case from the Eyre of Northamptonshire (1329-30). The owner of a house might lawfully kill one who entered it to rob, even if not in self defence. No pardon was required. In any other case a deliberate killing in the house could only be excused on the ground of self-defence;

- $\quad$ Case in $\mathbf{1 3 2 9}^{440}$ (Escape from Arrest). A case from the Eyre of Northamptonshire (1329-30). A man killed another and he was arrested by the townships and escaped from their custody. The pursued him and decapitated him since they could not take him alive. It was held justifiable;

- $\quad$ Case in 1348. ${ }^{441}$ (Robber refusing to Surrender to Constable). C was indicted for killing V, a robber. C showed V, and other robbers, a warrant to attach them and told them to surrender to the peace. They defended themselves, killing, and injuring, several people. $\mathrm{C}$ killed $\mathrm{V}$ in the fight. The jury said that $\mathrm{V}$ could not have been arrested in any other way. Thorpe CJ stated:

'They have acquitted you of this deed, and we acquit you. And I would tell you that when a man slays another under a warrant he may well admit that fact and we shall simply acquit him without any need for a royal pardon to be waited for in such a case, and so in many cases one man may kill another without liability, as where robbers come to kill a man or burgle his house, he may safely kill them if he cannot arrest them.

And note what happened where a gaoler went with a hatchet in his hand to the gaol, and the prisoners had broken their irons and were all trying to kill him and they injured him seriously, but he killed two of them with the hatchet and then escaped. And the Council decided in this case that he had only done what was lawful. Again he said that everyone may lawfully arrest robbers for robbery and felons for felony, and if they will not surrender to the peace but stand on their defence, or flee, he may kill them without blame.' 442

- Case in 1352. ${ }^{443}$ (Killing a Thief assaulting a Person). In an appeal of robbery there was an indictment for homicide. In this case the sarjeant asked the court what would happen to a person who killed a thief who assaulted him. They held that the thief would go quit; ${ }^{444}$

- Case in 1353. ${ }^{445}$ (Killing an Outlaw). A man killed an outlaw. His plea that it was justifiable homicide was overruled, although a prior case in 1328 was mentioned where it had been allowed. ${ }^{446}$ As Reeves noted, the law

439 Ibid, p 183. See also p 199 (a servant killing a burglar in his master's house).

${ }^{440}$ Ibid, p 188. Ibid, p 199 'It was presented that a prisoner was decapitated as he was being conducted to goal, because he fled and could not be retaken in any other way...It was ordered that the man who had decapitated the prisoner should be arrested. He would be arraigned for the killing, because he had made himself judge. But if the facts were found to be as described above, he would be acquitted.' See also pp 189 \& 207. Also, p 212 (Louth J, when a thief was decapitated immediately after the commission of a robbery as he fled, this could be more readily justified and was more reasonable than when a man was indicted, arrested and in custody).

${ }^{441} 22$ Edw 3 Lib Ass 55 fo 97b-98a. See Seipp no 1348.263ass. See also Kiralfy, n 428, p 27, Reeves, n 221, vol 3, p 120 and Jenkins 23 , case 62 (145 ER 17).

${ }^{442}$ Kiralfy, $\mathrm{n} 428, \mathrm{p} 27$. See also note of Seipp 'H. of Compton was indicted that he had feloniously killed H. Vescy at C. on a certain day in the 14 th year of the present king the sheriff had assigned the same H. (J.) of C. by a commission, which he put forward now to the Court, to attach and take the said $\mathrm{H}$. and the other robbers (larrons). This same H. of C. with others came to the place and there found the said $\mathrm{H}$. and the other robbers, and showed them the warrant that he had to attach them, and told them to surrender to the peace, and they did not want to surrender, but stood to defend themselves and killed and wounded several men (gents), and in this fight H. was killed. And he did not understand that the king would prosecute him for his death. Thorp CJKB said that everything would be inquired by the jury (Enquest), and he recited all as he had said. Therefore the jury should tell the Court if... if he could have been taken without his death, so that he killed him of his own will, and if they found these matters, then they should speak of his lands and chattels. The jury ( l'enquest) said as H. had alleged, and that there was no other H. V. than this one, and that he could not have been taken in another way... Thorp CJKB told the defendant that the jury had acquitted him of this deed, and the Court acquitted him, and Thorp CJKB told him that when a man killed another by a warrant, he could well avow the fact, and the Court would acquit him completely (nettement) without waiting for the king's grace by his charter (pardon) in this case, and also in many cases a man could kill another without prosecution (impechement), as if robbers came to rob a man, or to burgle his house, he could kill them safely if he could not take them. And note what happened to a gaoler who came to the gaol with a hatchet in his hand, and then the prisoners had broken their irons and were all ready to kill him, and they wounded him badly, but he killed two of them with the hatchet in his hand, and then escaped, and it was adjudged in this case by the whole Council that he had only done well (bien fait). Item, he said that each man of the people (could) take thieves (larrons) for larceny, and felons for felony, and if they would not surrender to the peace but stood to their defence, or fled, in such case he could kill them without blame...'.

${ }^{443} 26$ Edw 3 Lib Ass 32 fo 123b-124 (Seipp no 1352.096ass). Reeves, n 221, vol 3, p 119 'In respect of homicide when committed in defence of a man's property, it was held, that where a thief assaulted a man, and pursued him, if he killed the thief, the killer should go quit.'

${ }^{444}$ Seipp notes 'A serjeant asked the Justices what should be done when one who was appealed of robbery pleaded not guilty, and before the Venire facias he broke prison and fled to a church, and admitted the robbery and made abjuration. All said that the appellant would have the chattels (or the charter). And Willoughby JCP said this although he did not admit the robbery, still the appellant would have them. Also the serjeant said that one was indicted for the death of a man, where it was found that the person who was killed was a thief, and had assailed him, and had pursued him harshly and he killed him, if he would be acquitted, or it was necessary for him to have a charter (of pardon), and all said that he would go acquitted. And it was said that if one was taken in the county of S. with stolen goods of a robbery committed in the county of N., the justices of the county of S. would compel him to answer, and if he said not guilty, they would send for a jury (Pais) in the county of N. It was said that the Justices of Oyer and Terminer of felonies would put the chattels of felons in the street immediately, and deliver them to the vill, to answer to the king in the eyre.'

44527 Edw 3 Lib Ass 41 fo 137b. Seipp no 1353.166 ass. Seipp note J., widow of N. B., sued an appeal of the death of her husband against J. H., knight, and others. J. said that N. at the time of his death was outlawed for felony, and he did not understand that for his death etc. Shareshull CJKB said that one could kill a person who was outlawed for felony feloniously as well as another man; therefore he pleaded not guilty. A speaker said that H. of C. was excused for this reason of the death of the baron of Wodhal [see n 446 below].' 
between 1328 and 1353 had tightened up in respect of outlaws, providing a greater measure of protection for them. ${ }^{447}$

A later Act of 1532 - which held justifiable the killing of a person who attempted to murder, rob or burgle - likely derived from Thorpe CJ's opinion, see 20(d).

\section{(f) Cases of Excusable Killing}

In the case of self defence, the defendant was required to make out that he could not have 'otherwise escaped with his own life'. Thus, if the killer failed to flee when he could, self-defence was not possible, which principle followed that of Bracton. ${ }^{448}$ Cases in 1352 confirmed that it was justifiable to defend one's house as well as one's master (lord).

- $\quad$ Case in $1329{ }^{449}$ (Self Defence). O was taken for the death of one N. Jurors said that they quarrelled on the way to a tavern. N struck $\mathrm{O}$ with a wooden stave on the head so that he fell. The latter, as soon as he got up, fled as best he might. $\mathrm{N}$ kept pursuing him with the stick to kill him if he could and chased him to a wall between two houses, past which he could not go. Seeing that $\mathrm{N}$ wished to kill him and that he could not save his life except by defending himself, $\mathrm{O}$ took up a hatchet and struck $\mathrm{N}$ on the head, who died. The jury said that $\mathrm{O}$ killed in self defence and not by felony nor by malice aforethought [i.e. premeditation] and that, if $\mathrm{O}$ had not defended himself, he could not have escaped with his life. O was committed to prison and, later, given a pardon;

- $\quad$ Case in $1352{ }^{450}$ (Defending his House). The deceased and another came to the house of X, intending to set fire to it. X, from his house, fired an arrow, killing the deceased. This was held not to be felony;

- $\quad$ Case in $1352{ }^{451}$ (Servant defending Master). A thief robbed, and killed, a merchant. The merchant's servant came suddenly on the thief and killed him. This was held not to be felony;

- $\quad$ Case in $1369{ }^{452}$ (Not Self Defence). X pursued another with a stick and hit him. The victim struck back and killed his assailant. Because it was proved that the victim might have fled but, rather, chose to hit his pursuer, it was held to be felony.

\section{(g) Conclusion}

At this period, it seems that pardons were, generally, granted as a matter of course where there was homicide but it was accidental (i.e. in the course of no unlawful activity) or in self defence. ${ }^{453}$ In this period the law further emphasised that

4462 Edw. 3, Lib. Ass. P1 3, fol. 3a. Seipp no 1328.140ass. Same case in Hil. 2 (not 1) Edw. 3, pl. 17, fols. 6a-6b, Seipp no 1328.017. Seipp notes in respect of the first 'Henry C. was arraigned in the King's Bench for the death of P. of T., who was outlawed for felony, (Latin begins) as appears by the record (Latin ends), and judgment was demanded whether he should answer. Scrop CJKB said that it could be that the outlawry was reversed, or that he had a charter of pardon, and he said well to the defendant that even if a man was outside of the law, on that account one could not go and kill him. And if the defendant now went acquitted, he would go acquitted forever. Therefore the Court wanted to be certified by the Chancery whether he had a charter or not, and also they wanted to see their rolls, if the outlawry had been reversed or not. For this reason the defendant was told to find good mainpernors etc. Note this, where he was indicted for the death of a man. And see, (ex intenc'). Scrop CJKB said that if it were found that the outlawry had not been reversed, and that he had no charter of pardon, this H. would not answer further etc...'

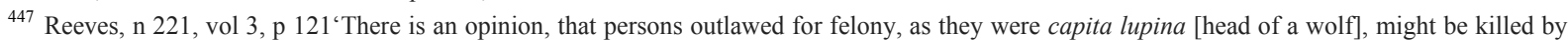
any-body; though Bracton lays it down otherwise; and says, that even where a sentence of law was not executed in due order, it was an offence. Very early in this reign we find a person arraigned for killing an outlaw for felony [see 1328 case]. In the $27^{\text {th }}$ year, in an appeal of death by a woman, the husband's outlawry for felony was pleaded [see 1353 case], and, though over-ruled, a case was mentioned where it had been allowed [see 1328 case]. It is probable, that the slayers of such unhappy objects went without punishment, rather from some peculiarity in the circumstances of the prosecutions then in use, than from any principle of law authorizing such barbarity.' See also Coke, n 44, vol 1, 128b.

448 See n 373 'otherwise escape danger.'

449 Osbern (1329). See also Kiralfy, n 428, p 26 and SS, vol 97, n 412, pp 164, 181. Also, p 166 (Richard of Ocle, fled to a wall), p 181 (Richard Abbot, fled to a ditch, pursuer ran upon his fork). See also, Stephen, n 55, vol 3, pp 38-9 and Fitzherbert, n 30, title Corone, nos 284 \& 285. JH Baker, Collected Papers on English Legal History (Cambridge UP, 2013), vol 2, ch 53, Some Early Newgate Reports 1315-1328, p 976 cited an early case before Geoffrey Scrope CJ [CJ, 1330-32] where a person pleaded not guilty to murder in that, being struck by a stick wielded by the deceased in a tavern, he had drawn a knife to ward off the blow. The deceased had then struck his arm against the knife, sustaining a fatal wound. Since he could not have otherwise escaped it was held to be self defence. See also Eyre of London 1321, SS vol 85, p 80-2 ( $R$ v Patrick).

${ }^{450} 26$ Edw 3 Lib Ass 23 fo 123a. Seipp No 1352.087ass. Seipp noted 'Note, that in an indictment for felony, the defendant put himself on the jury (Pais), and it was found that he was in his house, and the person who was killed and others came to his house to have burned him, and surrounded the house, but they did not do this, and the indictee shot (soht a) outside, and killed the person etc., upon which they adjudged that this was no felony. And he said further that it was adjudged by the whole Council that a thief killed a merchant, and the servant (garson) of the merchant came hastily afterwards and killed the thief who had robbed his master, that this was not a felony.' See also Reeves, n 221, vol 3, p 119 'where it was proved that the deceased and another came to the house of the defendant with a design to burn it, and the defendant, being then at home, shot an arrow, and killed the deceased; this was adjudged not to be felony.' See also Jenkins 30, case 57 (145 ER 22).

${ }^{451}$ See n 450. Reeves, n 221, vol 3, p 119 'It was at the same time said, that where a thief had robbed and killed a merchant, and the merchant's servant came suddenly upon the thief, and killed him it was not felony.'

45243 Edw 3 Lib Ass 31 fo 274b. Seipp no 1369.161ass. Note that at the deliverance made at Newgate before Knyvet CJKB and Lodelow CBEx, it was found by verdict that a chaplain had killed a man defending himself (self-defence). And the Justices asked how. They said that the deceased had pursued him with a staff (baston), and had struck him, but the other had struck him back, as a result of which he died, and they said that the one who had killed him could have fled the one who assaulted him, if he wanted to. And therefore the Justices adjudged him a felon, and said that he was bound to flee inasmuch as he could for the salvation of his life. And the chaplain was adjudged to the ordinary.' Reeves, n 221, vol 3, p 118 'Where one pursued another with a stick, and struck him, and the person stricken again struck the pursuer, of which blow he died; here, because it was proved that the person killing might have fled, but would not, rather choosing to assault the pursuer, it was held to be felony.' See also Holdsworth, n 65, vol 3, p 313.

${ }^{453}$ Stephen, n 55, vol 3, p 38 'The result of these authorities seems to be that, in the end of the thirteenth and the beginning of the fourteenth centuries, juries were bound in cases of trials for homicide, where the defence was misadventure or self defence, to find specially that such was the case, upon which the king was bound to grant his pardon. Probably he would do so upon terms as to fines and forfeitures which would depend on the degree of blame 
killers, robbers and thieves could be killed, if they resisted arrest or fled, and they could not otherwise be taken (cases in 1329 and 1348). Further, if a person attacked a man's house, to kill or burgle or commit arson, he 'might safely kill them if he cannot arrest them' (Thorpe CJ in 1348 and a case in 1352) or he might kill them in self-defence if he could not otherwise escape.

\section{Act of 1389 - Pardons}

In 1389, an Act ${ }^{454}$ was passed which sought to remove various abuses in the grant of pardons. It provided that:

Our lord the king...hearing the grievous complaint of his said Commons...of the outrageous mischiefs and damages which have happened to his said realm, for that treasons, murders [murdres], and rapes of women be commonly done and committed, and the more because charters of pardon have been easily granted in such cases...the king... hath granted, that no charter of pardon from henceforth shall be allowed before any justice for murder, or for the death of a man slain by await, assault or malice prepensed [murdre mort de homme occys per agayt assaut ou malice prepense] ....unless the same...be specified in the same charter...(underlining supplied)

In respect of this Act, Plucknett stated:

in 1390 the Commons secured a statute which recognised certain pardons as issuing from the Chancery as a matter of course (no doubt cases of self-defence or misadventure); with these the statute contrasts pardons for 'murders done in await, assault, or malice prepense'. In such cases pardons were subject to almost impossible conditions. The pardoning power in other cases was not touched, and so the Crown retained its normal powers and procedure for pardoning homicide, except cases of what we may call wilful murder. ${ }^{455}$

For his part, Stephen believed this Act to form:

the first statutory recognition of the expression 'malice aforethought', which ... had been previously employed by juries in finding special verdicts of se defendendo. It may, indeed, be regarded as an indirect new statutory definition of murder.... 456

While this may be the first statutory reference to 'malice aforethought' (premeditated malice), as noted, the concept existed in Anglo-Saxon (and Old Testament) times. Kaye summarised the consensus of modern opinion that this Act defined one particularly heinous form of culpable (intentional) homicide - killing by malice prepense - and attempted to make it impossible, or at least very difficult, for the Crown to pardon it. ${ }^{457}$ One would agree. The Act also referred to killing which occurred as a result of waylaying (highway robbery, agait) as well as a result of premeditated battery (assaut). This is understandable, since these comprise examples of premeditated malice and had been treated as such as far back as Babylonian times. $^{458}$

In conclusion, it seems likely that many intentional killings (including premeditated ones) were securing pardons in the rather chaotic times of the reigns of Edward III (1327-77) and Richard II (1377-99). However, the Acts of 1328 and 1390 effectively prohibited the grant of pardons vis-à-vis premeditated killing.

\section{From 1389 - 1551}

(a) $\underline{\text { Act of } 1512}$

In the period from 1389-1496, it would seem the law on homicide did not change much. However, in 1496, benefit of clergy was taken away in the case of petty treason. ${ }^{459}$ And, in 1512, benefit of clergy was taken away in the case of premeditated killing in certain situations. This suggests that (as in the period 1328-89) there had been latitude and now there was a toughening up in the attitude of Parliament (and, probably, the general public) in response. Thus, the Act of 1512 on Murders and Felonies, provided that benefit of clergy was to be taken away from:

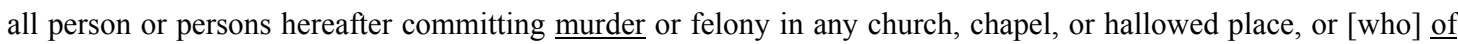
and upon malice prepensed, rob or murder any person or persons in the king's highway or else rob or murder any person in his house the owner or dweller of the house, his wife, child or servant then being therein and put in fear or dread by the same... ${ }^{460}$ (underlining supplied)

which might be considered to attach to the defendant by reason of the avoidable nature of the necessity under which he had killed the deceased, if the case was one of self-defence; or the amount of carelessness he had shown if the case was one of accident.' Green, n 94, p 426 'Until the thirteenth century, pardon in cases of excusable homicide was a matter of royal discretion; by the end of that century, it had become in practice a matter of the common law, issuing automatically and gratuitously, as a matter 'of course' (de cursu).'

45413 Ric II stat 2 c 1(1389)(rep 1948).

${ }^{455}$ Plucknett, n 221, pp 445-6. See also Maitland, n 13, p 305; Foster, n 77, pp 303-4 and Green, n 94, p 457 et seq.

${ }^{456}$ Stephen, n 55, vol 3, pp 43-4.

457 JM Kaye, The Early History of Murder and Manslaughter (1967) 83 LQR, p 368. See also WM Gordon \& TD Fergus (eds), Legal History in the Making. Proceedings of the Ninth British Legal History Conference. Glasgow 1989, ch 4, WDH Sellar, Forethoct Felony, Malice Aforethought and the Classification of Homicide.

458 See 6.

45912 Hen 7 c 7 (1496) which referred to 'wilful prepensed murders' and 'prepensed murder'. Plucknett, n 221, p 446 'The distinction becomes clearer in the Tudor reigns when benefit of clergy was being redistributed among the various crimes. Thus, James Grame wilfully murdered his master Richard Tracy, on $9^{\text {th }}$ February 1497 and then pleaded his clergy. An indignant Parliament was determined that he should hang, and so attainted him, and abolished clergy for his and all like cases of prepensed murder in petty treason.' It may be noted that the problem of benefit of clergy had been greatly exacerbated by an Act of 1352 ( $25 \mathrm{Edw} 3 \mathrm{st} 3 \mathrm{c}$ 4) which had extended benefit of clergy to secular as well as to religious clerks, and probably to all who could read. For a useful analysis during this period see also JH Baker, The Reports of Sir John Spelman, SS no 94, pp 303-16. See also J Baker, The Oxford History of the Laws of England (2003), vol 6, ch 31 ('Baker Oxford').

${ }^{460} 4$ Hen 8 c 2 (rep). See also Stephen, n 55, vol 3, p 44 and Baker, n 84, p 530. The Boke of Justices of Peas (1506, rep Professional Books Ltd, 1972) defined murder as 'where a man by malice purpensed lies in awayte [await] to slay a man and according to that malicious intent and purpose he slays him 
The taking away of benefit of clergy made it more difficult for a premeditated killer to escape the death penalty (a pardon would still be possible but, after the Acts of 1328 and 1390, it would have been much rarer). One other matter may be referred to. A premeditated killer could flee to sanctuary and, then abjure the realm, after confessing his crime. ${ }^{461}$ However, benefit of sanctuary was curtailed by Acts of:

$\begin{array}{ll}1529 & \text { it required branding; }{ }^{462} \\ 1530 & \text { it abolished abjuring the realm; }{ }^{463} \\ 1534 & \text { it abolished sanctuary for traitors; }{ }^{464} \\ 1540 & \text { it abolished sanctuary for premeditated killing ('willfull murdre'). }{ }^{465}\end{array}$

Sanctuary was abolished in 1623 (and all sanctuaries suppressed in 1696). ${ }^{466}$ Thus, Parliament was, clearly, seeking to restrict the means by which a person could 'get away with murder.'

\section{Thus, by 1540, a right of sanctuary for murder was abolished. \\ (b) Reading of 1520}

The various Acts from 1328 onwards, enabled there to be a greater clarification in the categorisation of homicide. By 1520 as the following Reading shows, the categories of homicide comprised:

- $\quad$ murder (killing with premeditation);

- manslaughter; and

- $\quad$ accidental killing (misadventure).

Thus, a Reading - probably delivered in Gray's Inn c. 1520/5 ${ }^{467}$ - states as to murder:

[Murder] there is another felony, which is called murder. For this the Statute of Marlborough [1267] c 25 provides that murdrum decetero non adjudicatur etc. ${ }^{468}$ Thus the common case of murder is where someone with malice aforethought (prepense) kills another: that is murder.

There is a distinction between murder, manslaughter (homycyde) and misadventure. Murder is always when someone kills another upon malice aforethought ${ }^{469}$ [malyse purpense].

Manslaughter (homycide). Homicide is, for instance, where someone assaults another, who flees from him and, in the last resort, in his defence and for safeguard of his life, without malice, kills the person who committed the assault, this is homicide and upon the special facts found he shall have his charter of pardon and shall lose his goods. $^{470}$ [i.e. self defence]

so that he which is slain makes no defence against him for if he do it is manslaughter and no murder... and manslaughter is where two men or more meet and by chance medley they fall at affray so that one of them slays the other...' (spelling modernized). See also Green, $\mathrm{n} 94, \mathrm{p} 475, \mathrm{n} 227$ who cites $\mathrm{T}$ Marow, Reading on the Peace (De Pace Terre et Ecclesie)(1503) 'murder ... where a man through malice aforethought lies in wait and kills any man...' Marow's Reading (a series of lectures in the Inner Temple) in 1503 (written in law French) is contained in BH Putnam, Early Treatises on the Practice of the Justices of Peace in the Fifteenth and Sixteenth Centuries (1924), p 332 et seq. See also Kaye, n 457, pp 572-5.

${ }^{461}$ Cox, $n$ 213, pp 10-1 notes that abjuring the realm was of Anglo-Norman origin and peculiar to England. It enabled an outlaw (one who committed a grave offence and fled from justice) to avoid being summarily killed by seeking sanctuary, confessing his crime to a coroner and then abjuring the realm for good. He was unable to return without the king's licence. See also Bracton, n 22, vol 2, p 382 (so long as they were in the king's highway they were under the king's peace). See generally on sanctuary and abjuration, Holdsworth, n 65, vol 3, pp 293-307.

46221 Hen $8 \mathrm{c} 2$ (rep). This Act provided that all felons and murderers taking sanctuary and making abjuration were to be marked with a hot iron with the letter A on the thumb, or else lose all benefit of sanctuary. See also Cox, n 213, p 321.

46322 Hen 8 c 14 (rep). This Act abolished abjuring the realm. Such a person must now remain in a sanctuary for life, on pain of death. Sanctuary men committing new offences were to lose all benefit of sanctuary and be committed to jail. See also Cox, n 213 , p 321.

46426 Hen 8 c 13 (rep). Traitors were not to have any benefit of sanctuary. See also Cox, n 213, p 322.

46532 Hen 8 c 12, s 2 (rep). The Act also abolished all special or chartered sanctuaries and replaced them with sanctuaries in 8 towns (Wells, Westminster, Northampton, Norwich, York, Derby, Manchester, Launceston). See also Cox, n 213, p 326 and Holdsworth, n 65, vol 3, p 306.

$46621 \mathrm{Jac} 1 \mathrm{c} 28$, s 7 (1623, rep, no sanctuary or privilege of sanctuary should thereafter be admitted or allowed). See also 8 \& 9 Will III c 26 (1696, rep). See also Trenholme, n 213, p 31 \& Cox, n 213, pp 326 \&

467 J Baker (ed), Selected Readings and Commentaries on Magna Carta 1400-1604, SS, vol 132, pp 183-4. See also Baker, n 84, p 530 who noted that, by this time - principally as a result of the 1512 Act (see (a)) - Parliament had thus superimposed on the common law a tripartite classification of homicides: 'if the killing was done out of malice, it was punished by death and forfeiture; if there was no prior malice, and it was a first offence, it was clergiable and the only certain punishment was forfeiture; if the killing was accidental or excusable, it was pardonable.' See also Baker, $\mathrm{n} 459$, pp $315-6$. ${ }^{468}$ See 14 .

469 It continues 'as where two men by malice assault another with intent to kill him, and one of them kills him, and the other does nothing, the one who does nothing shall [also] be called a murderer. If a gaoler by malice, entreaty or bribe keeps another so harshly that he perishes, it is murder. If someone committed [to goal] maliciously kills his warder and escapes, it is murder and he shall be hanged.' See also Fitzherbert, $\mathrm{n} 39$, (1538) fo 19 referred to the 'murder of another, whom he of malice prepensed lying in await, did kill.' and to 'manslaughter as a thing feloniously done by chance medley.' Also, 'murder, and manslaughter, of which the one comes by malice prepensed, and the other but by chance.' (spelling modernised). See also SS vol 120, p 183 (Roger Yorke's Notebook), 'Note that murder is where a man lies in wait to murder any person, or murders any person of his malice aforethought; this is called murder. But if a man kills someone by chance medley. without malice aforethought, this is not properly murder but manslaughter. Thus, there is a distinction: by Elyot [JCP] at Exeter assizes [1507-22].' See also Green, n 94, p 478 and Baker, n 459, p 304 'in normal usage, the word 'murder' had by 1500 taken on by association the sense of a killing by malice aforethought.' See also Baker Oxford, $\mathrm{n} 459$, $\mathrm{p} 558$.

470 This is really excusable homicide (self defence). The Reading continues 'If a surgeon administers ordinary medicine, or otherwise acts with good zeal concerning his faculty, but the patient nevertheless dies, this is not homicide or felony punishable by the law. The law is the same of a physician. [Because it is accidental killing]. But if he administers such medicines with intent to kill him, and he dies from them, it is felony even though he did the thing by colour of his office and craft (colore officii et artis sui).' See also Baker, n 459, p 315. 
Misadventure and misfortune. [i.e. accidental killing] Misadventure or misfortune is when someone carries on a lawful craft (art), such as the office of carpenter or tiler, or is shooting at the butts, and in doing such things, without any malice, he kills another by misfortune, against his will, this is misfortune and not felony or homicide: nevertheless he shall lose his goods. In the same way he shall lose his goods when he kills another in self defence.

But if someone carries out an unlawful practice, which he is not compelled to perform by any necessity, or for any common profit, as where someone throws a stone over a house, and such like, and by accident (per casualte) he slays another, this is homicide and felony, and he shall lose his life. The law is the same of sword and buckler, if a man kills another. ${ }^{471}$ Thus there is a distinction whether the practice is lawful and for the common good at the beginning, and where not, unless in special cases. ${ }^{472}$ (underlining supplied)

In this Reading, while there was now clarity in respect of the description of 'murder', there was little in respect of manslaughter which incorporated (inappropriately) excusable homicide (self - defence). Nor was there an adequate distinction drawn between accidental and negligent killing. Finally, there was a failure to separate - in terms of law punishment for an unlawful act, from when death then resulted. The result was that an unlawful act - even if accidental could result in manslaughter, if death ensued and, in murder, if intentional.

\section{(c) Act of 1531 - Murder Unclergyable}

An Act of $1531^{473}$ made 'wilful murder of malice prepensed' a felony without benefit of clergy. It stated that benefit of clergy was to be given to:

no person or persons which hereafter shall happen to be found guilty after the laws of this land for any manner of petty treason, or for any wilful murder of malice prepensed... (underlining supplied)

This Act tightened up that of 1512 (see (a)). Maitland indicated that - with this Act of 1531 - there became two kinds of homicide for which the punishment was death. One was murder (now, an unclergyable felony). The other was manslaughter (a clergyable felony). ${ }^{474}$ Similarly, Plucknett stated: ${ }^{475}$

one of them [the Act of 1532] uses (probably for the first time) the words 'wilful murder'; from that date it is clear that the statutes have, in effect, divided the old felony of homicide into two separate crimes, "wilful murder of malice aforethought' which was not clergyable and therefore capital, and on the other hand, those homicides which were neither in self-defence, nor by misadventure [accident]. Some such division was obviously necessary, but unfortunately the boundary was generally sought in glossing the ancient formula 'malice'. ${ }^{476}$

The effect of this Act was, at last, to more precisely define what was murder - although, even then, in practice, there seems to have been some uncertainty. ${ }^{477}$

\section{Thus, by 1531, the right to claim benefit of clergy in respect of murder was abolished.}

\section{(d) Act of 1532 - Killing a Thief}

This Act ${ }^{478}$ noted that it was uncertain ('in question and ambiguity') whether a person who killed another who:

attempted to rob or murder any person or persons in or nigh [near] any common highway, cartway, horseway or footway, or in their mansion, messuage or dwelling places or that feloniously do attempt to break any dwelling house in the night time

forfeited, as a result, their lands, tenements, goods or chattels. The Act provided that no such forfeiture was to result. Also, that such a killer:

shall be thereof and for the same fully acquitted and discharged, in like manner as the same person or persons should be if he or they were lawfully acquitted of the death of the said ill disposed person...

This Act, effectively, re-stated and clarified what was the common law position in relation to the same in the time of Bracton,

\footnotetext{
${ }^{471}$ Reference is made to 11 Hen $7 \mathrm{pl} 14$ fo $23 \mathrm{a}$ (1496.029). Seipp commentary: 'Fyneux CJKB: if two play (ludunt) together with sword and buckler (= shield), or they joust (justent) together by their common assent, if the one kills (occist) the other, it will be called felony, because even though these games (ludes) are allowable (soufferables) by law, yet it is not lawful to use them except by the king's command when he (the king) commands them to joust, or to play (luser, should be luder?) with swords and bucklers before him (before the king)...it is otherwise if it be by the king's command, as in joustings (Justings), or suchlike distinction between accident and felony also mentioned in 1498.005 = Hil. 13 Hen. 7, pl. 5, fol. 14a-14b (mayhem).' See generally, McBain, n 215, App G. Cf. A Fitzherbert, Some new cases of the years and time of King Hen 8, Edw 6 and Qu Mary written out of the great Abridgment composed by Sir Robert Brook (1651), p 74 'Note, by the justices, that tis felony to kill a man in j[o]usting, or where men play at sword and buckler, and the one kills the other, and the like notwithstanding the commandment of the king, for twas against the law.' He cited Brooke, $\mathrm{n} 31$, title Corone, no 228.

472 SS, vol 132, pp 183-4.

47323 Hen VIII c 1 (1531). See also Foster, n 77, p 304. For the general history see Hale, n 45, vol 2, chs 46 \& 47.

${ }^{474}$ Maitland, n 13.

${ }^{475}$ Stephen stated, n 55, vol 3, p 45 'We have thus arrived at the point at which homicide was finally divided into two main branches, namely, murder which is unlawful killing with malice aforethought, and homicide in general, which is unlawful killing without malice aforethought, the one offence being within, the other without benefit of clergy. The subsequent history of the definition consists mainly, though not entirely, of the process by which a definite meaning was put upon the words 'malice aforethought.'

${ }^{476}$ Plucknett, n 221, p 446. See also Reeves, n 221, vol 3, pp 393-4.

477 See Reeves, n 221, vol 4, pp 393-4. 'It is certain that, after this Act, murder was more exactly defined as to its legal import; though the distinction plainly marked out by this statute was not observed by the courts for some time, as we shall see again in the reign of Queen Mary [1553-8].'

${ }^{478} 24$ Hen VIII c 5 (rep). Hale, n 45, vol 1, p 487 stated 'This [Act] was to remove a doubt, and was declarative and enacting, and puts the killing of a robber in or near the highway etc in the same condition with one, that intends to rob or murder in his dwelling house, and exempts both from forfeiture, and has settled the doubt.' Stephen, n 55, vol 3, pp 39-40. P \& M, n 88, vol 2, pp 478-9 'In 1532 there was need for a statute to say that a person who killed any one who attempted to rob him in his own house or on or near the high-way should not incur a forfeiture of his goods.' See also Green, $\mathrm{n} 94$, pp $480-1$.
} 
some 300 years before (see $\mathbf{1 3 ( d ) )}$.

In conclusion, the Act of 1532 provided that it was justifiable to kill a person who: (a) attempted to rob or murder him, whether in (or near) a highway; or (b) attempted to burgle their house at night. Given that this made the killing justifiable, as opposed to where it was excusable in such circumstances when in self-defence, one imagines that, where possible, this Act was pleaded. However, it also (likely) started the overlap (and later confusion) between justifiable and excusable homicide, in this area.

\section{(e) Reading of 1551}

Reference may also be made to a Reading in 1551 of Robert Brooke (when he was recorder of London) on Magna Carta, ch $17,{ }^{479}$ which Reading included:

what acts shall be called murder and what homicide, and what not; and where a man may justify a man's death. ${ }^{480}$

Brooke's approach (effectively) was to list cases on homicide:

- Justifiable. Brooke mentioned cases where the killing was justifiable. It was justifiable if the following were killed:

$\circ \quad$ pursuant to due legal process; ${ }^{481}$

- a man indicted of felony resisting arrest - if he could not otherwise be taken; ${ }^{482}$

○ a thief (or burglar) resisting arrest - if he could not otherwise be taken; ${ }^{483}$

○ where the Act of 1293 applied (see 17) (i.e. a person in a warren etc. resisting arrest, if he could not otherwise be taken); ${ }^{484}$

○ an escaping prisoner - if he could not otherwise be stopped; ${ }^{485}$

$\circ \quad$ an arsonist; ${ }^{486}$

$\circ \quad$ a robber; ${ }^{487}$

- a man subject to a praemunire; ${ }^{488}$

- a Turk or Jew who was in England without a safe conduct. ${ }^{489}$

All these had considerable precedent to them. The exception was the last which seems to have been the personal opinion of Brooke; one which Coke was to reject (see 28).

\footnotetext{
479 See ch 18 'No sheriff, constable, escheator, coroner or other our bailiff shall hold pleas of our crown.'

${ }^{480}$ See SS, vol 132, pp 188-90. See also The Reading of M Robert Brook upon the Statute of Magna Carta, chap 16 (London, printed by M Flesher \& R Young, 1641).

${ }^{481}$ Ibid, p 189 'A man is adjudged to death, and the sheriff beheads him (decolle), that is murder'. Brooke referred to 35 Hen 6 fo 58 , pl 2 (actually pl 3, not 2), see Seipp no 1457.022 (1457) 'Pole JKB: yes, Sir, it (decapitating a felon instead of hanging him) is felony, because he (Bingham JKB's sheriff) did not have power to kill him except according to the judgment, and if he did otherwise, he did it as a stranger, and so it is felony.' See also Baker, $\mathrm{n} 459$, p 315 .

482 Ibid, p 188 'A man is indicted for felony, and a capias is awarded to arrest him; he makes resistance, and the officer kills him, for he could not otherwise take him; he may justify this.' Brooke referred to a case in 1348, see n 441. See also C St German, Doctor and Student (1528), SS, vol 91, p 265 who noted that 'though a man be outlawed for murder or felony or be abjured or that he be otherwise attainted: yet it is not lawful for no man to murder him or slay him nor to put him in execution [i.e. execute him] but by authority of the king's laws'. (spelling modernized).

${ }^{483}$ Ibid. 'The law is the same where a thief comes to rob me, or to burgle my house, and in arresting him I kill him, if I could not otherwise take him.' Brooke referred to a case in 1348, see n 441. See also St German, n 482, p 265 'if a man that is no officer would arrest a man that is outlawed, abjured or attainted of murder or felony... and he disobeys the arrest and by reason of that disobedience he is slain: I suppose the other shall not be impeached for his death for it is lawful unto every man to take such persons and to bring them forth that they may be ordered according to the law.' (spelling modernized) . See also Baker, n 459, p 307.

${ }^{484}$ Ibid. 'A warrener finds someone wandering in a warren and raises the cry upon him to give himself up to the warrener, and he refuses to surrender but flees, or defends himself with force and arms, and WS (who is accompanying the warrener) kills him in the course of arrest, he may justify.' See Act of 1293, see 17.

485 Ibid. 'If a gaoler comes into the prison and finds the prisoners loose, having broken their irons, and standing to their defence, and he cannot take them except by slaying them, he may justify the slaying...' Also, 'A prisoner in custody for felony breaks the prison and escapes, and [JS] sees this and knows it, and cannot take him except by death, and so slays him, he may justify...' Brooke referred to a case in 1348 , see $n 441$.

${ }^{486}$ Ibid, p 189. 'A thief comes along and is about to burn the house of [JS], who shoots an arrow at him and slays him: this is not murder or homicide.' Brooke referred to a case in 1352 , see $\mathrm{n} 450$.

${ }^{487}$ Ibid. 'A thief assaults a man in order to rob him, and he kills him, this is not murder or felony.' Brooke referred to a case in 1352 , see $\mathrm{n} 443$. Baker, $\mathrm{n}$ 459, p 315.

488 Ibid. 'A man kills [JS], who has been attainted in a praemunire, this is not felony of death, because he is not within the king's protection but outside it.' Fitzherbert, n 471, p 72 'Note twas holden by all in the house of Parliament, that if a man kills one who is attainted by praemunire, this is no felony, for he is out of the protection of the king, which is, as if he were out of the kingdom, and power of the king. Otherwise of him who is attainted of felony and judged to death, the killing of him is felony. $24 \mathrm{H} 8$ [1532] B[rooke] Corone 196.' Praemunire was a royal writ to protect royal rights of jurisdiction and was developed in the fourteenth century to punishment papal encroachments. See Walker, $\mathrm{n} 80$ (praemunire). Baker, SS vol 94, n 459, p 307 'There remained a doubt as to persons attainted of praemunire on the statute of 1353 [Statute of Praemunire 1353], because the statute gave liberty to treat such persons as if they were the king's enemies.'

${ }^{489}$ Ibid, p 190. 'A Turk or Jew comes into England without the king's licence, and [JS] kills him, that is not murder or homicide for he is not a Christian (de ley de Christe) nor within the lord king's protection.' Baker in a fn to the text of Brooke (SS, vol 132, p 190, n 8] stated: 'This opinion seems to have been peculiar to Brooke: 94 SS [The Reports of Sir John Spelman], p 306. Francis Mountford, reader of the Inner Temple, held that it was felony to kill an alien with no safe conduct.' See also Baker, n 459, p 306
} 
- $\quad$ Excusable. Brooke indicated that a servant defending his master could kill the attacker. ${ }^{490}$

- $\quad$ Premeditated. Brooke gave the following examples of murder:

- Death - Neglect. 'a man comes to hunt in a park and takes the keeper, ties him to a tree, and puts a gag in his mouth so that he will not make a noise; the keeper dies of hunger: this is murder'; ${ }^{491}$

- Death - Neglect. ' a man takes his father, who is gravely ill, and maliciously carries him from one town to another in a great frost on pretence of friendship [to seek physic], whereby the cold kills him, this is murder in the son'; 492

- Quack Doctor or Surgeon. 'A physician or surgeon takes a man in cure, and he dies through insufficient medicines, this is not murder or homicide; but if someone who is not a physician or surgeon takes upon himself to be a physician or surgeon and takes a man in cure, who dies through bad medicines, this is murder.' 493

These examples were held to be premeditated and, thus, to merit the death penalty, without possibility of pardon. In the case of the last, this seems unconscionably harsh to the modern mind. However, it was (doubtless) to suppress quacks - who were likely treated as the successors to sorcerers - and it reflected prior legal analysis in respect of the same.

- Manslaughter (Not Premeditated). Brooke gave the following examples:

- 'two men are fighting, and [JS] comes to depart [break up] the affray, and one in hitting the other strikes [JS] and kills him, without malice towards him, this is still homicide and felony of death, for he saw him. ${ }^{494}$ It would be the contrary if he had been behind the person who killed him when he struck'; ${ }^{, 45}$

- ' a man kills someone who is outlawed for felony, it is felony of death'. 496

Although intentional, these killings were held manslaughter (as was executing a person lawfully but in the wrong manner) since the act was unlawful. Being a felony, the death penalty still applied. However, (unlike murder) - a pardon was possible and such an offence was clergyable (there was also a right of sanctuary);

- $\quad$ Accident. Brooke gave the following examples:

$\circ \quad$ 'a man crops a tree and a branch falls on [JS] and kills him, without the awareness of the cropper, this is not felony of death for it is without felonious intent (animo felonico)'; ${ }^{497}$

- ' $\quad{ }_{498}$ man shooting at the pricks [archery butts], his arrow swerves and kills [JS], this is not felony of death.'

In conclusion, Brooke, in 1551, provided a useful summary of the categories of homicide. There was nothing surprising about most of his statements since Yearbook cases provided long established precedent.

\section{Summary - Law to 1551}

If one reviews the law from the time of when Bracton wrote (c.1240) up until 1551, the law on murder and manslaughter had become more clear - since the definition of premeditated killing was now, generally, termed 'murder'. The position from $1240-1551$, therefore, may be summarised as follows:

- Murder If it was premeditated, it was called 'murder'. The confusion with the older 'murder fine' was gone, the latter having been abolished in 1340. For murder the death penalty applied. And this was difficult to escape from given that: (a) since 1531, murder was not clergyable; (b) since 1540, no sanctuary was possible; (c) since 1328 and 1390, a pardon was unlikely to be granted. Thus, apart from the rare prospect of securing a pardon, the hangman's noose awaited a murderer;

- Manslaughter. This was a felony. However, up to 1628 when sanctuary was abolished, sanctuary was available. And, up to 1827 - when benefit of clergy was abolished - it was also available. Finally, there was a greater chance of securing a pardon. In the case of intentional killing, murder was extenuated to manslaughter in the case of a

\footnotetext{
490 Ibid, p 189. 'A master and servant are riding down the road, and a thief assaults the master and strikes him to death; the servant comes up quickly to assist his master and slays the thief; this is not murder or homicide or felony in the servant...' Brooke referred to a case in 1352, see $\mathrm{n} 451$. See also 21 Hen $7 \mathrm{pl} 50$ fo 39 (1505), Seipp no 1505.050 in which Tremalye JKB indicated that a servant could slay in order to defend his master if his master could not otherwise escape. Baker, n 459, p 315 (excusable to kill in defence of one's master and near relations).

491 Ibid, p 190. Brooke did not provide a citation.

492 Ibid. Brooke cited a case in 1328 , see n 432.

493 Ibid. Brooke cited a case in 1330 (Nottinghamshire Eyre). See also Fitzherbert, n 30, title Corone, n 163.

494 Ibid, p 188. Brooke cited a case in 1348, see $\mathrm{n} 433$.

495 Brooke cited Case of Thorns (1466) 6 Edw IV pl 18, fo 7 per Bryan serj. See Seipp no 1466.020. 'Sjt Bryan... if one assaults me, and I cannot avoid him, but he wants to beat me, and I in self-defence (en defence de moy meme) raise my staff (leve mon baston) to strike him (percuter), and one is behind me (a mon dorse), and in raising my stuff I hurt (lede) him, in this case he (the one behind me) will have an action against me, yet my raising of my staff (baston) was lawful for my self-defence (defense moy meme), and also I hurt him unwillingly ('me invito'), etc...' [i.e. accidentally]

496 Ibid, p 189. Brooke cited a case in 1328, see n 446. See also n 445 and St German, n 482.

497 Ibid. Brooke cited Case of Thorns (see n 495). This was also an example under Roman law, see n 194.

${ }^{498}$ Ibid. Cf. a case in 1329 (accidental killing when shooting at butts), see n 428. See also Case of Thorns (see n 495), Seipp commentary ‘

Sjt Fairfax: there is a distinction where one does a thing from which a felony would ensue, and (does a thing) from which a trespass would ensue... because felony is malice aforethought (malice prepence), and when it was against his will, this was not 'felonious animus' (animo felonico), etc...if one shoot (arrows) at targets, and his bow (arke) trembles (swacset) in his hand (mein), and kills another against his will (ipso invito), this is no felony, as has been said, etc., but if he hurts another by his shooting (of arrows), he will have a good action of Trespass against me, and yet the shooting (of arrows) was lawful, etc., and the wrong (tort) that the other suffered was against his (the shooter's) will, etc., so here, etc.'
} 
brawl (hot blood). Manslaughter appeared to cover all other cases of homicide (even accidental killing when unlawful, see Reading of 1520, see $\mathbf{2 0 ( a ) ) ~ - ~ s a v e ~ w h e r e ~ t h e ~ s a m e ~ w a s ~ t r e a t e d ~ a s ~ a c c i d e n t a l ~ k i l l i n g ~ o r ~ j u s t i f i a b l e ~ o r ~}$ excusable homicide;

- $\quad$ Accidental. Accidental killing was still treated as homicide. That is, a criminal act. Thus, a pardon was required although it was, generally, granted as a matter of course;

- Justifiable - Common Law. In the time of Bracton, it was not a crime to kill: (a) pursuant to due legal process; (b) an outlaw; (c) a thief with the goods on him; (d) a manifest felon who resisted capture; (e) a burglar (night thief); (f) a housebreaker; (g) (possibly) a perjurer; (h) an enemy in a just war. By 1551, (b) no longer applied (since 1353) nor (c) and (g). However, the others did - with Thorpe CJ in 1348 expressly confirming (d), (e) and (f). Also, that (i) a gaoler could kill an escaping prisoner; 499

- Justifiable - Legislation. (a) an Act of 1293 made it justifiable for a forester to kill a trespasser who resisted arrest; (b) an Act of 1532 made it justifiable to kill a person attempting to murder, rob or burgle at night;

- Excusable. In Bracton's time, it was a defence to kill a person: (a) in self defence; ${ }^{500}$ (b) to defend one's family (and servants) ${ }^{501}$ (c) to defend one's master (lord). This still applied in 1551. Killing in self defence was still treated as homicide. That is, a criminal act. Thus, a pardon was required although it was (generally) granted as a matter of course.

\section{Act of 1553 on Unlawful Assemblies}

This Act - which was an 'Act against unlawful and rebellious assemblies' - provided another case of justifiable killing. Section 6 stipulated that it was lawful for any JP (or other stipulated officer) - after a proclamation had been given for such an unlawful or rebellious assembly to disperse:

to suppress apprehend and take those persons so unlawfully assembled... and if the said persons so unlawfully assembled together or any of them shall fortune [happen] to be killed...every such Justice of the Peace [etc] shall be freed discharged and unpunishable as well against the Queen, and against all and every other person or persons of for or concerning the killing. ${ }^{502}$

In conclusion, this Act was the precursor to the Riot Act 1714. The justification for such killings being lawful was (likely) one of public policy - to prevent civil disturbance and uphold the law.

\section{Staunford (1577)}

Staunford - in his Les Plees del Coron (1577) - considered homicide. However, as Stephen noted, his analysis was little more than a commentary on Bracton ${ }^{503}$ and somewhat cursory in nature. ${ }^{504}$ Staunford defined murder as killing with malice prepense ${ }^{505}$ which he contrasted with chance medley. However, this was incorrect since, as Lambard noted (see 24), manslaughter could also cover killing that was not chance medley (for example, negligent killing other than in a brawl). Staunford is not considered further since both Lambard and Coke analysed matters in greater detail.

\section{Lambard (1581)}

Lambard, in his Eirenarcha (or the Office of the Justice of Peace) published in 1581, provided a fuller analysis than Staunford on the law of homicide. ${ }^{506}$

\section{(a) Murder}

Lambard defined murder, saying that it occurred:

if any person have of prepensed malice, killed or murdered an other openly, or privily, whether he that was killed were an Englishman, or a stranger, living under the protection of the Queen. ${ }^{507}$ (underlining supplied)

\footnotetext{
499 See $\mathrm{n} 441$.

500 TA Green, Societal Concepts of Criminal Liability for Homicide in Medieval England (1972) Speculum 47, no 4, p 669 'The rules of self-defence were rigorous throughout the entire medieval period. The slayer had to have made every possible attempt to escape his attacker, must have reached a point beyond which he could not retreat and must have retaliated out of literally vital necessity.' He cited, at p 573, the case of 33 Hen VI pl 10 (1454) per Prisot J [see 33 Hen $6 \mathrm{pl} 10$ fo 18b (1455), Seipp no 1455.037] 'if a man assaults you in order to beat you it is not lawful for you to say you want to kill him and to endanger his life and limb: but if the case is such that he has you at such advantage that he intends to kill you as you seek to flee and he is swifter than you and pursues you so that you are unable to escape; or if you are on the ground under him; or if he chases you to a wall or hedge or dike, so that you cannot escape, then it is lawful for you to say that if he won't desist, you want to slay him to save your own life, and thus you may menace him for such special cause...' The result of such a high threshold was likely 'fact coloration in cases of self defence' as Green put it, $\mathrm{p} 685$.

${ }^{501}$ Ibid, p 680. A man could kill to defend his wife from rape, but it was felony to kill a man in flagrante with one's wife. See Baker, $\mathrm{n} 459$, p 315 and App D(d).

5021 Mar sess 2 c 12, s 6 (rep 1863).

503 Stephen, $\mathrm{n} 55$, vol 3, p 46 'The part of the work which relates to homicide is little more than a commentary upon Bracton.' Stephen also stated: 'My edition is dated 1607, but I do not think it can be the first.' This is correct. The first edition was in 1557, which I cite.

${ }^{504}$ Ibid. '[Staunford] contrasts murder with chance medley, and so recognises two kinds only of voluntary homicide, namely, voluntary [intentional] homicide with malice prepense, and voluntary homicide upon a sudden quarrel. The subsequent history of the definition shows what a superficial view of the subject this is, and what important distinction it altogether fails to notice.' See also Reeves, n 221, vol 4, p 537. See also Kaye, n 457, p 583 'Staunford...used the term chance medley as a synonym for manslaughter.'

505 Staunford, n 41, p 18 'quant ascun de malice prepense tua auter felonisment' (when a person with malice prepense kills another feloniously).

506 A useful work on murders in the $16^{\text {th }}$ century is Bellamy, $\mathrm{n} 251$, p 11 who noted that killing with a knife or a dagger or stunning the victim with a blow on the head and then cutting their throat, were the most common means of murder in those times.

${ }^{507}$ Lambard, n 40, p 324 (by the 1599 ed, the word 'stranger' was replaced by that of 'alien'). Lambard, pp 212-3 thought that the word 'murder' did not derive from the murder fine but rather from the Anglo-Saxon word morth and the Hebrew ' $m o t h$ ' (one would agree, see ns 81-2). Lambard stated: 'in old
} 
Lambard treated duelling as murder. ${ }^{508}$ He also gave examples two examples which highlighted the problems of whether an act was manslaughter or murder:

- $\quad$ Fighting - Peacemaker Slain. Lambard stated:

'if $A$ does assault $B$ and strikes him, and while B defends himself, $C$ comes to part them, and is slain by $A$ this is felony in $A$ ' As authority Lambard cited a case in 1348. ${ }^{509}$ Since the act was unlawful (A striking B), it could not be treated as an accident;

- 'But if they both had appointed the place of purpose, to meet there, to fight one with the other, and $C$ were slain in seeking to appease them, then will it be felony in both the other.' (underlining supplied) ${ }^{510}$

The second example referred to an important case in Lambard's time, that of Herbert (1558). Herbert, with 40 or more, had assembled at the house of $\mathrm{M}$ for the purpose of an affray but (it seems) with no intention of killing anyone. During the affray, M's sister - seeking to intercede - was killed by a rock thrown by one of H's servants. The court was divided over the issue (the final outcome of the case is not known).

- Unlawful Act. The majority (including Saunders CJ) seem to have held - on the initial evidence - that $\mathrm{H}$ and his accomplices were guilty of murder, since the affray was an intentional unlawful act in which killing resulted. ${ }^{511}$ However, since they also referred to the case of duelling (where persons agree to meet with an intention to kill) the majority could have, as easily, held $\mathrm{H}$ guilty of transferred malice, if, on the evidence, $\mathrm{H}$ had come to the affray with an intention to kill. ${ }^{512}$ The concept of transferred malice had been recognised since the time of Bracton; ${ }^{513}$

- Hot Blood. Conversely, the minority opinion of Brooke CJ and other judges (including Dalison) was based on the affray being a 'hot blood' (chance medley) scenario and not a 'cold blood' one. ${ }^{514}$

This case is important since it shows that both: (a) transferred malice; and (b) unlawful act, can occur in the same case. Also, both were not examples of murder as such, since there was no express malice (grudge) against the victim. Here, the murder was implied by virtue of a fiction of law (also called an implication, or construction, of law). However, this case also shows a real problem with 'implying' murder, in that there is an inherent 'flaw' in the nature of such implications.

- Since Brooke CJ viewed the affray as one in 'hot blood', if the peacemaker had not been killed but one of the combatants, then it seems clear that, this would have been manslaughter, being in 'hot blood'. But because an affray was also an 'intentional unlawful act', and because the same could be treated as murder (indeed, even if accidental, see Reading of 1520 (see $\mathbf{2 0 ( d )}$ ), then it could be treated as murder, simply as a result of alternative categorisation;

- $\quad$ Since the courts took a dim view of duelling (vast numbers of men were to die in France as a result of duelling and one suspects that the Queen (Elizabeth I (1558-1603)) did not want the same throughout her reign ${ }^{515}$ one suspects that Saunders CJ and the majority may well have taken the stance they did as a matter of 'public policy' because it meant that, if any third party peacemaker was killing in a duel or affray, it was murder. Thus, this warned potential

time every killing of a man was of the effect called murder because death ensued of it (for of the Hebrew word moth (saith Postellus) comes the latin mors, which the Saxons (our elders) called morth and morthor as we yet found it: so was that wilful manner of slaying with malice prepensed long since and most properly called felonie, because it was done felleo animo, in malicious heat and displeasure, and per felonia as the Statute at Marlebridge [1267, see 14] does term it...'. The reference to 'Postellus' is to William Postell, De Originibus seu de Hebraicae Lingua (1538). Postell (1510-81) was a noted linguist of his time.

${ }^{508}$ Lambard, n 40, p 256 'So it is taken if two fall out, and do appoint a place to fight together, and there the one of them kills the other.' This was murder, being pursuant to a duel. Lambard referred to Dalison, see The Reports of William Dalison 1552-1558, SS 124, p 130, to the case of Herbert (1558) in which Dalison states: 'Note also, by the justices, that where two men intend to fight together and appoint a place to do it, and when they are together one of them kills the other, this is clearly willful murder in the one who killed, even though his intention was only to beat or wound him, for that goes to the person and he is slain in that malice.'

${ }^{509}$ Lambard, n 40, p 217. For the case in 1348, see n 433. Lambard also cited Fitzherbert, n 30, title Corone, no 262. What if the peacemaker kills one of those fighting? John Grene, who gave a Reading in the Inner Temple in Lent 1499, stated, Readings and Moots at the Inns of Court in the Fifteenth Century, SS, vol 105, p 300 'if someone in separating two people who are fighting kills one of them, without any malice, it is felony, because the act itself is felony.' [because it was unlawful]

${ }^{510}$ Ibid. Lambard cited The Reports of William Dalison, n 508, p 128 et seq, Herbert (1558), see App C(a). See also Lambard (1599 ed), p 238.

${ }^{511}$ Dalison, n 508, p 129 where Saunders CJ referred to 'wilful murder because it began upon an unlawful act to be done to a man's person, in which act they had malice to do an evil thing against the law, and in that malice the woman's death happened, and therefore it is murder'.

${ }^{512}$ Ibid, p 127 'But Saunders CJ and others were of the clear opinion that if two people are fighting together with the intention of killing each other, or of beating or [wounding] each other, and a stranger intervenes to separate them, and one of them kills him, this killing of the stranger in this way is murder, even though there was no premeditated malice between the stranger and the one who killed him, inasmuch as he (namely the stranger) was slain in the malice which the other bore.' (underlining supplied). The underlined wording indicates cold blood (the third party killed in the course of a duel). In Plummer (1701), see App C(b), it seems clear that Holt CJ interpreted Herbert as a case where they came with premeditated malice, see p 115 'they came with malice against B and in pursuance, and in execution of that riot the woman was killed.' See also Baker Oxford, n 459, pp 556-7.

513 See App G.

${ }^{514}$ Dalison, n 508, pp 128-9 'it was not murder but manslaughter: for murder is the killing of a man with malice aforethought... and they had no malice towards the woman. They said, however, if M...or any of his servants in his company had been so killed, that would clearly have been murder.' However, this logic is faulty. If, during the affray, the combatants intended to kill, this was no longer a matter of 'hot blood', in which case the majority opinion of Saunders CJ was correct (because transferred malice). The crucial issue was whether the woman was killed during a 'hot blood' event or not. See also Reeves, n 221, vol 4, pp 533-6 and Kaye, n 457, pp 378-9.

${ }^{515}$ R Baldick, The Duel. A History (1965), p 52 between 1589-1607 'no fewer than four thousand gentlemen were killed in affairs of honour.' 
troublemakers that they could be in very serious problems if they indulged in acts of violence which 'spilled over' to third parties; ${ }^{516}$

- It may be noted that the same problems arose in the law of treason, in the case of constructive interpretations of 'levying war' in the Treason Act 1352. Because the Act only referred to 'levying war' (leve de guerre), the Tudor judges implied another provision of the Act (compassing the death of the sovereign) to cover conspiring to levy war. However, this simply undermined the express reference to levying war.

In the case of murder, the Tudor judges (as in the case of treason) developed more legal fictions (implications of law). One can see why they did it.

- $\quad$ The pre-requisite of 'premeditated' for murder was too narrow (just as the terms of the Treason Act 1352 were too narrow) and making other acts murder by implication not only inappropriately transposed the ' $m e n s$ rea' from one act onto another but such categorisation was still too limited for the very varied fact situations that arose;

- As mentioned at the beginning of this article, the disaster for the law on homicide is that simple principles have been made unnecessarily complicated by: (a) unduly restrictive categorisation; (b) the employment of legal fictions.

The other legal fictions in respect of premeditated malice will now be considered.

\section{(b) Murder - Implied Malice}

The inadequacy of basing murder on the need to show premeditated malice - as opposed to intention - was further highlighted by the courts, in this period, 'implying' malice even where there was none, since the killer did not know his victim and, therefore, there could be no personal animosity towards the same. Stephen (writing in 1883) - referring to a later edition of Lambard (not the first in 1581, but the 1599 edition) - cited 4 cases of implied malice (though he, mistakenly, only discussed 3 of them). Thus, Stephen quoted Lambard as follows:

- No Provocation. Lambard stated: 'if one do (suddenly, and without any outward show of present quarrel or offence) draw his weapon and therewith kill another that stands by him, the law judges it to have proceeded of former malice, meditated within his own mind, however it be kept secret from the sight of other men; ' 517 An early case supporting this proposition was Anon (1557); ${ }^{518}$

- Killing an Officer. Lambard stated: 'it has been adjudged murder when a man has drawn his weapon, and killed either a known officer, or one that had and showed sufficient warrant to arrest him for debt only. ${ }^{519}$ This proposition may have derived from a proclamation of $1538 .{ }^{520}$ Alternatively, Grace (1580); ${ }^{521}$

- Killing pursuant to Unlawful Act. Lambard stated: 'wheresoever a man goes about an unlawful act as to beat a man and disseize him of his lands etc, and do (in that attempt) kill him, it is murder, because the law presupposes that he carries that malicious mind with him that he will achieve his purpose though it be with the death of him against whom it is directed'. For this proposition Lambard cited Brooke CJ in Herbert (1588) (see above discussion); ${ }^{522}$

- $\quad$ Thief Kills. Lambard stated: 'if a thief do kill a man whom he never saw before and whom he intended to rob only it is murder in the judgment of law, which implies a former malicious disposition in him rather to kill the man than not to have his money from him, ${ }^{523}$ An early case where this was suggested by Plowden was in $15755^{.524}$

\footnotetext{
${ }^{516}$ A similar policy was likely taken in the case of Lord Dacre (1541-2), App C(a). Under the Act of 1293, foresters could kill those who came to steal game and who fled or defended themselves (see 17). The likely effect of this was that such thieves, probably, often agreed to kill the forester, if challenged. This case made it clear that all those involved could be treated as accessories to the murder.

${ }^{517}$ Stephen, n 55, p 50. For the 1581 edition (the wording was slightly different), see n 40, p 255. Lambard referred to Dalison's reports, probably to Eldred (1560), App B(d). See also Kaye, n 457, p 591 and Stephen, n 55, vol 3, p 50.

${ }^{518}$ In Anon (1584), App B(d), p 67 'Manwood [CB] put the case, that...if one strike a child in the street with a dagger whereof it dies, it is murder, and yet there is no known malice, but malice intended.' See also Burchet (1574), App B(c).

${ }^{519}$ Stephen, n 55, p 50.

${ }^{520}$ The Proclamation of 18 April 1538 provided: 'if any person or persons slay and murder any of the said officers and ministers [i.e. those with authority ...for due execution of justice] in and for executing and doing of their offices in attaching or arresting any of them by their bodies...in every such case [they] shall suffer death without remission or pardon; and that they nor any of them shall have or enjoy the privilege of any sanctuary nor their clergy.' See PL Hughes \& JF Larkin, Tudor Royal Proclamations (Yale, 1964), vol 1, 263.

${ }^{521}$ Anon (1584), App B(d), p 67 'Manwood [CB] put the case, that, if he be required by a watchman in a city or town to stand and yield himself, and does not, but kills one of the watchmen, that is murder, for it has malice in law: and so if one kill a sarjeant or officer in making an arrest, it is murder. And the case of the serjeant was adjudged at Newgate against Glover who killed Grace the serjeant [in 1580]. For in all these cases the parties are warranted by law to kill or arrest the other; and then to kill them that are warranted by law is murder.' See also Baker Oxford, n 459, p 556 and Kaye, n 457 , p 591 referring to Young (1586) 4 Co Rep 40a (76 ER 984) at 40b, murder 'if the constable or any of his assistants is killed in suppressing and affray'. For the cases of Glover and of Prise (1582)(he murdered a sheriff's sarjeant who had just arrested him), see Bellamy, n 251, pp 50-1.

${ }^{522}$ Lambard, n 40, pp $256-7$ 'Brooke [CJ] was of opinion, 4 \& 5 Phil \& Mar [1558] that in all cases, where a man alone, or with other, comes to do an unlawful act to an other, as to beat him or disseise him of his land etc and kills him in that doing, it is murder: but if a stranger be killed there, that then that is but manslaughter [because no malice to the stranger]. And Dalison agrees with the first part of this opinion.' (underling supplied). Brooke CJ was CJ of the Common Pleas from 1554-8. See also Herbert as reported by Dalison (see n 508), p 131 'Brooke CJ of the Common Pleas said that in all cases where someone comes accompanied with a multitude of people to do an unlawful act, such as beating someone or disseising someone, or putting him out of his house, if this man is killed during this entry or battery, by him or his companions (or any of them), this is murder. It is otherwise if a stranger is killed in the entry or battery: that is but homicide, for it comes by chance medley. In the first case, however, the malice and killing come to the party himself.' See also Ibid, p 130. See also Kaye, n 457, pp 592-3.

${ }^{523}$ Stephen, n 55, p 50.

${ }^{524}$ Lambard, n 40, p 256 referred to Saunders \& Archer (1575), see App G at p 474 where Plowden had suggested a thief so killing would commit murder. See also Herbert (1588) in Dalison, n 508, p 130 'Note also, by the justices...if someone lies in wait to beat another, or to rob him of his goods,
} 
Stephen indicated that Lambard assumed that 'malice aforethought' (malice prepensed) was the same as premeditation 525 and noted that Lambard gave examples of what was afterwards called implied malice 'in a way which involves some fiction, but much less than was afterwards imported into the subject. ${ }^{526}$ As to 3 of the above examples of implied malice (Stephen evidently forgot that he cited 4) Stephen commented as follows:

- No Provocation. Stephen considered the example of there being no provocation (see above) to be rational enough (doubtless, because it could not be argued that it was negligent or accidental or in self defence or as a result of provocation). However, Stephen indicated this example failed to include where a person killed on a slight provocation or 'mere wantonness' (by which he meant mere randomness or 'universal malice', as Blackstone was later to term it). ${ }^{527}$ One would agree with Stephen;

- Killing an Officer. As to the killing of an officer, Stephen noted that Lambard cited it without attempting to reconcile it with the words 'malice prepense, ${ }^{528}$ It is irreconcilable since it (clearly) can cover where a person kills an officer 'on the sudden' such as in a fight in hot blood, where there is no premeditation;

- $\quad$ Thief Kills. As to killing by a thief, Stephen also noted that it was difficult to locate any malice prepense. ${ }^{529}$ This, also, is irreconcilable since the thief may have killed accidently or negligently (or even in self defence).

The fourth example of Lambard in (b) above is an important one (which Stephen may have overlooked since he failed to identify the case which is Herbert (1558)). Brooke CJ's dictum was an extensive one. Any battery, for example, causing death was now murder. Further, Brooke's view was not out of kilter with that of other lawyers (see Reading of 1520 (see 20(d)) where even accidental unlawful acts were treated as murder). One suspects that Brooke would probably have limited his implication to unlawful acts of violence. However, as will be seen, Coke (and Hale) ended up endorsing the proposition that even accidental killing when committing an unlawful act, was murder. Finally, Stephen missed out the fact that Lambard also cited other examples of implied malice, viz.

Transferred Malice. ${ }^{530}$ This was not express malice, since there was no 'malice' against the person killed. However, malice was 'implied' because it was transferred;

Neglect/Cruelty. Lambard (in the 1599 edition of his work) mentioned that it was murder in the case of neglect or cruelty - such as a mother abandoning her child to die or taking a parent out into the cold to die (effectively, euthanasia) or a gaoler killing his prisoner through harsh treatment. ${ }^{531}$ Whether these were implied or express malice is debatable since there seems to have been a strong element of premeditation (it was treated as premeditated in 1328 (see 13(d)) when the concept of 'implied malice' had not yet been conceived. Some later writers (such as Blackstone) treated it as express malice. Today, such acts would, likely, be treated as acts of commission rather than of omission.

As it is, these examples of Lambard (and statements of Stephen) reflect the inadequacy of implying malice when there was actually none and the following may be noted:

- at this stage of legal development, there was no need to preserve a distinction between premeditated and unpremeditated intentional killing (although the latter was clergyable until 1827). Murder should have covered both, with an exception being made for provocation - something which later eventuated;

- $\quad$ further, today, one would say that it was 'public policy' considerations (the need to increase the ambits of murder) which dictated, in that time, that the following should be accounted murder by way of legal fiction (implication):

(a) unprovoked killing;

(b) killing a police officer in the execution of his duty;

(c) killing arising from an unlawful act;

(d) killing by a thief (robber); ${ }^{532}$

and in like manner if someone assaults another with the intention of robbing him of his goods or beating him, and in this ambush and assault the man against whom the assault is made is slain, this is clearly murder, according to all the justices, since a kind of malice came to the man's person.'(italics supplied)].

${ }^{525}$ Stephen, n 55, vol 3, p 50 'Lambard is, I think, the first writer who gives an account of the meaning of malice aforethought, showing that the unsatisfactory nature of the phrase was beginning to be understood. He does not attach any artificial meaning to the phrase itself, but assumes that it bears its natural and obvious sense of premeditation.'

${ }^{526}$ Ibid, p 50 .

${ }^{527}$ Ibid, p 51 'If A suddenly but obviously intentionally kills B without any apparent motive, it is no doubt reasonable to suppose that he had some motive that was not apparent, but Lambard's statement is incomplete, for it takes no notice of the case of sudden killing in which there really is no antecedent malice as, for instance, killing upon a slight provocation or in mere wantonness. It is impossible not to ask why a man should in such a case be in any better position than one who kills another suddenly for some unknown cause; and it is not obvious why a fiction should be employed in order to put him in the same position.'

${ }^{528}$ Ibid. 'Lambard merely states the rule of law, that such a killing was held to be murder without attempting to reconcile it to the words 'malice prepense'. It might have been reduced to a case of sudden killing without provocation, which he does deal with.'

${ }^{529}$ Ibid. 'The law can hardly be justified in 'presupposing' that a thief 'carries that malicious mind that he will achieve his purpose though it be with the death of him against whom it is directed', from the fact that he trips a man up in order to rob him and happens to kill him.'

${ }^{530}$ Lambard, n 40, p 218 citing Saunders \& Archer (1575), see App G.

531 Ibid (1599 ed), p 236. Pulton cited case in 1328, see n 432 and 1599, see App B(e). In respect of a jailer, reference was made by Lambard to Britton (c.1290), see App B (f).' The notorious case of Richard Hunne (1509-47) who was found dead in his cell in 1512 but was likely murdered may have influenced harsh treatment by jailers being treated as murder, see Bellamy, $\mathrm{n} 251$, pp 3-11.

${ }^{532}$ The implied malice really flows from the Act of 1532 (see 20(d)). Given that it was justifiable to kill a thief seeking to rob one (see Act of 1532 ), it is fairly obvious that thieves, knowing this, would be, more likely, to kill the victim when the latter sought to resist. 
(e) transferred malice;

(f) killing by neglect/cruelty (to the extent not express malice) ${ }^{533}$

It may be noted that subsequent legal writers treated killing by poison as a type of 'implied malice'. Lambard did not and this would seem correct since poisoning had (since Babylonian times) been treated as an example of premeditation. Further, an Act of 1547 had expressly made it murder. ${ }^{534}$

In conclusion, in Lambard's time (1581), there should have been an evaluation whether - basing murder on the presence of 'premeditated malice'- was too restricted. Instead, the courts started implying malice, when there was none (just as they did with the development of similar legal fictions in the case of treason). The effect of this was to confuse the law on homicide greatly.

(c) Manslaughter

Lambard stated:

in common speech manslaughter is taken to be a special manner of wilful [i.e. intentional] killing without any malice forethought of ${ }^{535}$...Also, 'If any person have by chance medley feloniously killed an other.' ${ }^{36}$

Lambard gave examples:

- Chance medley. Lambard stated: 'if two do suddenly fall out, and thereupon draw their weapons, and one kills the other, this is manslaughter ...' 537 This was distinguishable from a situation where two had previously agreed to fight (a duel), which would be murder (see (a));

- Sudden Involvement. Lambard stated: 'if one be in the company of him that of malice prepense sets upon another to murder him, and does of a sudden take the murderer's part, so that the other party is slain, this is manslaughter in him according as the word is commonly understood.' 538 This example is only correct if the killer intervenes in 'hot blood';

- $\quad$ Authorised Martial Games. 'if two play at fence, or run at the tilt together, and one of them be slain: for their first act was unlawful, unless it had been by the Queen's licence. ${ }^{539}$ If it were licensed, then it would be an accident. If unlicensed, it was manslaughter.

\section{(d) Justifiable Killing}

Lambard cited as examples of justifiable killing, when:

- $\quad$ pursuant to due legal process; ${ }^{540}$

- a felon resisted arrest; ${ }^{541}$

- a prisoner sought to escape; ${ }^{542}$

- the Act of 1293 (on warrens) applied (see 17); ${ }^{543}$

- the Act of 1532 (attempting to murder, rob or burgle) applied (see 20); ${ }^{544}$

- the Act of 1553 (on unlawful assemblies) applied (see 22). ${ }^{545}$

\footnotetext{
${ }^{533}$ I say 'to the extent not express malice' since there seems to have been an active ingredient of 'plotting' (intention) in the 1328 and 1599 cases and also, doubtless, where a jailer starved his prisoner or placed him in manifestly insalubrious conditions.

${ }^{534}$ See 1 Edw 6 c 12(1547)(rep 1828), killing by poison was deemed 'willfull murder of malice prepensed.'

${ }^{535}$ Lambard, n 40, p 212.

${ }^{536}$ Ibid, p 324.

${ }^{537}$ Ibid, p 217. See also 1599 ed, pp 243-4 'chaunce medley, for that in it men are medled (or committed) together by mere chance, and upon some unlooked for occasion, without any former malice or evil mind in one, to offer hurt to the person of the other.' See also Baker, n 459, p 310 .

${ }_{538}$ Ibid. This is likely based on Salisbury (1553), see App D(c).

${ }^{539}$ Ibid. Lambard cited a case in 1496, see 471. See also Baker, n 459, p 313 and App F. See also a proclamation of 1538 (see n 520) which stated 'his majesty [Henry VIII, 1509-47], being credibly informed that divers and sundry his subjects have lately been murdered and slain in sundry frays happening by chance by reason of sudden foins [thrusts, stabs] with swords and other weapons, minding to take away the occasion of such slaying and murdering, doth straightly charge and command that no person or persons in any fray or fight that shall happen or chance between them shall use in his fight any foin or foins with his sword or other his weapon; and if any such person or persons from henceforth slay or murder any by occasion of such foin or foins, that then the offender contrary to this proclamation shall suffer death without remission or pardon, and shall lose his clergy and privilege of sanctuary.' See also OED, n 82 (foin).

540 Ibid, p 213

${ }^{541} \mathrm{Ibid}$, if the sheriff or any other do by warrant or on hue and cry made, arrest one indicted of felony which [who] does resist and is slain thereby this fact done upon this necessity is justifiable by necessity.' Lambard referred to a case in 1348, see n 441 and to Fitzherbert, n 30, title Corone, 288, 289, 290 adding 'For all these former cases tend to the commendable advancement of law and justice.'

${ }^{542} \mathrm{Ibid}$ 'So if prisoners do assault their keeper, and in his defence he strikes any of them to the death'. He cited a case in 1348, see n 441.

543 Ibid, p 215.

${ }^{544}$ Ibid. 'So it is if any do attempt to rob or murder one in his mansion house or dwelling place, or nigh [near] any common highway, cartway, horseway, or footway, or feloniously to break into his dwelling house in the night time, and in this their attempt, the party or his servants then with him do kill any of the misdoers (though the law was somewhat doubtful before) it is now made out of the question by the statute $24 \mathrm{H} 8$ c 5 [see Act of 1532, see 20(d)] and he shall not forfeit anything for that fact, but shall go quit for in these cases of necessity he defends himself and his goods against robbers and other notorious evil doers.' As to the definition of burglary, Lambard, $\mathrm{n} 40, \mathrm{p} 221$, followed the definition of Britton, $\mathrm{n} 23, \mathrm{p} 36$ 'Such we hold to be all those who feloniously in time of peace break churches, or the houses of others, or the walls or gates of our cities or boroughs.'

${ }^{545}$ Lambard, $\mathrm{n} 40, \mathrm{p} 214$ 'And be reason of their [those unlawfully assembled] still continuing together after proclamation made, [the JP or other officer] be driven to set upon them, and thereby any of the stubborn persons be slain. This slaughter done upon this necessity is so justifiable both in the justice
} 
These instances had clear precedent. Finally, Lambard confirmed that executing a person attainted on a praemunire was not justifiable. $^{546}$

\section{(e) Manslaughter - Self Defence \& Accident}

Lambard treated killing in self defence ${ }^{547}$ and by accident ${ }^{548}$ as manslaughter (following precedent), for which a pardon was required. Lambard also noted that killing by sorcery was now a separate crime ${ }^{549}$ as were perjury ${ }^{550}$ and poisoning. ${ }^{551}$

\section{(f) Conclusion}

The categorisation of malice into 'express' and 'implied' malice - which Lambard was one of the first to enunciate - was unhelpful since it produced yet more artificiality rather than a review as to whether, by the late $16^{\text {th }}$ century, it was appropriate to use premeditation as a means of defining murder.

- Also, the failure to separate the unlawfulness of an act, from the separate act of killing, added to the confusion;

- Despite the legal confusion, there were also some advances. By 1562, to kill a person attainted of praemunire was not justifiable. Further, sorcery and perjury were treated as separate crimes. Thus, to kill sorcerers and perjurers summarily (without trial) was not justifiable (though, likely, this had been the legal position for a long time). ${ }^{552}$

\section{In conclusion, Lambard was one of the first legal writers to present a coherent analysis of the law on homicide.}

\section{Statute of Stabbing 1603}

After James VI of Scotland became James I of England (1603-25) and came down to London, there was often antagonism between Scotsmen and Englishmen in England, with duels and brawls. ${ }^{553}$ An Act of 1603 provided that:

Every person... which shall stab or thrust any person or persons that hath not then any weapon drawn, or that hath not then first stricken the party, which shall so stab or thrust so as the person so stabbed or thrust shall thereof die within the space of six months then next following, although it cannot be proved that the same was done of malice

himself and every other of his company, that they ought not in any manner to be molested for it.' In the 1610 ed, p 235, Lambard stated 'if the [JP] come to arrest rioters, and they resist, whereby one of the rioters is slain by any of the justices, or their servants, or by any other coming in their aid, that is justifiable, and allowed by law: because in this, and the former cases, the killing proceeds upon a necessity for the execution of justice, which otherwise should be left undone.' This may also be a reference to the Case of Armes (1597) Popham 121 (79 ER 1227), where an assembly of judges on 15 April 1597 held that 'men may arm themselves to suppress riots, rebellions or to resist enemies, and to endeavour themselves to suppress or resist such disturbers of the peace, or quiet of the realm. It was resolved that every JP, sheriff or other minister or other subject of the king, where such accident happen may do it. With regard to the Statute of Northampton (1328)(riding or going armed) 'upon cry made for weapons to keep the peace, every man where such incidents happen for breaking the peace, may by law arm himself against such evil doers to keep the peace. But they take it to be the more discrete way for every one in such a case to attend to (and be assistant to) the JP's, sheriffs or other members of the king in the doing of it.'

${ }^{546}$ Ibid, p 215. See 5 Eliz 1 c 1, s 18 (1562) which made such killing unjustifiable. Re an outlaw, see ns 445 \& 446. Cf. SS, vol 120, p 97 (Roger Yorke's Notebook) 'note that by the law of the realm if someone is outlawed, and a man kills him, the murder shall not be punished: by Fitzherbert and Spelman JJ., Mich 27 Hen VIII [1535].'

${ }^{547}$ Ibid, p 216 'But if he be in an affray is of necessity driven to kill the other in defence of his own life, after that he has fled as far as he can'. Lambard continued 'although it be not accounted felony yet the Statute of Gloucester cap 9 [1278, see 15] wills that such a one be imprisoned till the coming of the justices of goal delivery, and there (putting himself upon God and the country) the whole matter is to be found by the verdict and then the king shall grant him a pardon of course, but he shall forfeit all his goods for having killed the king's lawful subject and therefore the justice of peace may well under the name of manslaughter in this statute take upon him (as I think) to commit such an offender and to take examination... according to the statute...' Lambard cited 43 Ass pl 3 (it should be pl 31, see n 452).

548 Ibid, pp 218, 216 \& 139. Lambard gave various examples: (a) 'If a man lay poison for rats, and another takes it unawares, and dies thereof, this is not any ways to be laid to the other's charge'; (b) '[where] one kill an other by misadventure against his will, as by casting a stone, or shooting an arrow, or felling of a tree unadvisedly or such like;' (c) 'If a man also hurt or kill an other, at fence play, or at the tilt, tournament or barriers (in presence of the Queen, and by her licence), or in a wager of battle for the trial of a cause according to the ancient laws of the realm, it is no breach of peace at all.' In the case of (c), Lambard referred to a case in 1496, see $n 471$.

549 Ibid, p 321 'If any person has used invocation, or conjuration of evil spirits for any cause: or has used witchcraft, inchantment, charming, or sorcery, whereby any person is killed or destroyed'. Lambard cited 5 Eliz 1 c 16 (1562, rep).

${ }^{550}$ Ibid. 'If any person has unlawfully procured any other person to commit willful and corrupt perjury in any cause depending in suit in any of the Queen's courts of record, or in any leet, court baron, hundred, or court of ancient demesne: or has corruptly suborned any witness sworn to testify in perpetuam rei memoriam: or if any have upon such procurement, or by his own act willfully committed such perjury.' Lambard cited 5 Eliz $1 \mathrm{c} 9$ (1562, rep. A perjurer was fined $£ 20$ as well as 6 months imprisonment and disability) and 14 Eliz $1 \mathrm{c} 11$ (1572, rep). For an interesting case of procuring a child to commit perjury, see Anon (1538) Spelman's Reports, SS, vol 93, p 60.

${ }^{551}$ Ibid, p 324. 'If any have wilfully killed any other by poisoning and who be his aiders, abettors, procurers, and counsellors.' See also Stephen, $\mathrm{n} 55$, vol $3, \mathrm{p} 45$.

${ }^{552}$ As previously noted, both Britton and Fleta (in 1290, see 16) thought that perjury leading to the death of a person was a capital crime. However, even then, the summary killing of a perjurer (or sorcerer) must, surely, have not been justifiable. See generally, Holdsworth, n 65, vol 4, pp 507-11 (none of the Acts mentioned by him suggested that it was justifiable to kill a sorcerer).

${ }^{553}$ Stephen, n 55, vol 3, p 47 '[the Act was] said to have been passed on the occasion of the frays then common between Englishmen and the Scotchmen who resorted to the court of James I. The preamble says that the act is passed 'To the end that stabbing and killing men on the sudden, done and committed by many inhuman and wicked persons in the time of their rage, drunkenness, hidden displeasure, or other passion of mind' might be restrained. Blackstone, n 48, vol 4, p 193 'This statute was made on account of the frequent quarrels and stabbings with short daggers, between the Scotch and the English, at the accession of James the First; and being therefore of a temporary nature, ought to have expired with the mischief, which it meant to remedy...but the benignity of the law has construed the statute so favourably in behalf of the subject, and so strictly when against him, that the offence of stabbing stands almost upon the same footing, as it did at the common law.' See also Keite (1696), see App B(g) at p 139 and Hunter (1685) 3 Lev 255 (83 ER 677) at p 256. See also Eden, n 48, p 232. 
forethought, ... shall be excluded from the benefit of his clergy, and suffer death as in the case of wilful murder. ${ }^{554}$ (underlining supplied)

As Stephen noted, this Act showed that 'malice prepense' was construed in its 'popular sense' (i.e. a reference to premeditation). ${ }^{555}$

\section{Pulton (1609)}

Pulton, in the first edition of his De Pace Regis et Regni (1609), considered murder and manslaughter. His definition of homicide followed that of Bracton (see 13). He stated:

Homicide is a word compound, and is derived of these two words, viz. hominis and caedium, and the most apt and proper definition thereof is, when one man or more men do kill another man: ${ }^{556}$

Following Bracton, Pulton categorised homicide into: (a) intentional; ${ }^{557}$ (b) accidental (mischance); (c) justifiable; and (d) excusable. In the case of (a), he sub-divided it into: (i) murder; and (ii) manslaughter. ${ }^{558}$

(a) Murder

Pulton stated:

the name of murder is an old and ancient term, and it is the rather continued to make a difference between homicide committed by chance medley, and homicide committed by malice prepensed. ${ }^{559}$ And therefore if a man be indicted of murder, a pardon of all felonies will not excuse and discharge him ... ${ }^{560}$ for murder is a more grievous and hateful offence in the hearts, and ears of men, than other felonies be. ${ }^{561}$

Pulton provided various examples:

- $\quad$ Third Party Assisting. Pulton stated: 'If a man go with malice prepensed to fight with an other, and to kill him, and a third person seeing them fighting, goes on the sudden without malice, to take the part of him that went with his malice, and to fight for him, and then they two [both] strike and kill the man that was by them assaulted: this is wilful murder in the first man which went with the malice prepensed to kill, and but manslaughter and not murder in the other who went to take his friend's part, and had no malice prepensed to kill, ${ }^{562}$ The reasoning was that the original party had premeditation, the third party killed in 'hot blood';

- Master \& Servants. Pulton stated: 'As if the master upon malice prepensed does lie in wait to assault and kill a man, and takes some of his servants with him that he does not acquaint with his malicious intention, and the master does assault the same person who he did lie in wait for, and does fight with him, and the servants do take their master's part, and fight with the party assaulted, and they together do kill him; this is wilful murder in the master, and but manslaughter in the servants, for that in them there was no malice prepensed towards the parties slain. ${ }^{563}$ The reasoning was that the master had premeditation, the servants killed in 'hot blood';

- $\quad$ Third Party Peacemaker. Pulton stated: 'if two men be fighting together, and a third man comes to part them, and he is slain, by one of those two without any malice prepensed, or evil intent in him that slay him: this is murder in him that killed him, and not homicide by misadventure, because they both that fought together were doing of an unlawful act. And if they both that did fight together, come thither with malice prepensed, one intending to kill the other, then it is murder in them both.' 564 The first example was murder since the parties were unlawfully fighting, and, although they were fighting in 'hot blood', killing the third party was murder (on the basis of Herbert (1558, see 24(a) $)^{565}$ The second example was that of a duel. Since it was premeditated, the killing was murder, by way of transferred malice. These examples follow Lambard (see 24(a)).

These examples were well established. Pulton also noted the following comprised murder (by implication):

\footnotetext{
5541 Jac 1 c 8 (1603)(rep 1828). Baker, n 84, p 531, the issue of provocation was 'facilitated by the [Act] which took away benefit of clergy for killing by stabbing, where the deceased had no weapon drawn, even where at common law the killing amounted only to manslaughter.'

555 Stephen, $\mathrm{n} 55$, vol 3, p 47. Stephen also pointed out, pp 48-9, that the Act was not well drafted and it assumed that no provocation - except drawing a weapon or actual striking - was sufficient to reduce killing by a stab from murder to manslaughter. 'This produced so harsh a result that the judges would not apply it.'

556 Pulton, $\mathrm{n}$ 42, p 120. He continued 'for if a man be killed by a dog, a beast, or other thing, it is not properly termed homicide.'

${ }^{557}$ Ibid. 'By will [intention], as when one man has a will [intention] to fight with another, and then does kill him, or some other that is in his company, and does take his part in that combat.'

${ }^{558}$ Ibid 'But of this homicide by will there be two sorts, whereof the one is called murder, and that is, when one man upon malice prepensed, and forethought, does feloniously kill an other. And the other is called manslaughter, or chance medley, and that is, when two men fight together upon a sudden heat of blood, without any malice precedent, and one of them does kill the other.'

${ }^{559}$ Ibid, p 123 'Homicide by murder is when one man upon malice prepensed does kill another feloniously.' See also J Cowell, The Interpreter (1607)(murder) 'It signifies in our common law, a willful and felonious killing of any other upon prepensed malice...'. Also, W West, Of Symboleography (1597, Pt 2, Offences, s 47 'Murder...is the willful and felonious killing of any other of premeditated malice...'

${ }^{560}$ Pulton referred to the Act of 1389 , see 19.

${ }^{561}$ Pulton, n 42, p 123.

562 Ibid, p 124. This followed Lambard, see 24. See also Sir Fernando Cary (1616), App D(c)

563 Ibid, Pulton continued 'But if the master had made his servants privy to his intention, and they had gone with him and killed the other, it should have been adjudged murder in the servants also.' See Salisbury (1553), App D(c).

564 Ibid, p 123.

${ }^{565}$ In the margin, p 123, Pulton cites Dyer 128 but means Dalison 128.
} 
- killing a police officer in the execution of his duty; ${ }^{566}$

- $\quad$ killing by neglect; ${ }^{567}$

- transferred malice, ${ }^{568}$

- unlawful act. ${ }^{569}$

Pulton also stated, in respect of intentional, unlawful, acts (likely following Brooke CJ in Herbert (1558), see 24(a)):

If a man intending the death of another, does beat him so grievously that he does leave him by all the beholders judgment thought to be dead, and then does fly away, and after the other does revive and live; this is not felony in him that does the violence, though it does plainly appear that he has a meaning to kill him: for it is not felony, except the party stricken be indeed killed, and die within a year and a day after the stripes [beating] given. ${ }^{570}$

But on the other side, if one man does strike another, with intent only to beat him, yet if he die of this battery within a year and a day after, it is felony in him that did strike him. For though, as Bracton affirms, the old law of the realm did hold, quod in maleficiis [autem] spectatur voluntas et non exitus, et nihil interest, utrum quis occidat, an causam mortis praebeat: ${ }^{571}$ but now we say lex antiqua mutatur, [the old law has changed] and do affirm, quod exitus in maleficiis spectatur et non voluntas dumtaxat [in crimes the result is regarded, and not simply the intention].

Unlike Lambard, Pulton does not seem to have dealt with murder when arising from: (i) unprovoked killing; or (ii) a thief (or robber) killing. ${ }^{572}$

\section{(b) Manslaughter}

Pulton indicated that manslaughter covered killing: (i) by chance medley ${ }^{573}$ (which he did not further discuss since he covered it in examples he had previously given of murder); and (ii) pursuant to an act that was unlawful.

\section{(c) Accidental Killing}

Pulton stated:

Homicide by misadventure is when any person without evil intent does a thing that is lawful, or which is not prohibited by the law, and yet another is slain, or comes to his death thereby. ${ }^{574}$

Pulton cited various examples. ${ }^{575}$ However, the act had to be lawful, for it to be an accident. ${ }^{576}$ If it was unlawful, it was manslaughter.

\section{(d) Justifiable Killing}

\footnotetext{
${ }^{566}$ Ibid, p 124 'If upon a fray made, the constable with others to assist him, do come to part the fray, and to preserve the peace, and in doing of his office, the constable, or any of his assistants shall be slain, this is wilful murder in him that slew him, although the murderer did not know the party whom he killed, and although the affray was on the sudden: because the constable and his assistants came by authority, warrant, and command of the law to keep the peace, and avoid danger which might ensue by the breach thereof: and therefore the law does adjudge this murder, and that the murderer had a prepensed malice in him, to oppose himself against the law and the justice of the realm. And if the sheriff or any of this bailiffs, or officers be killed in the execution of the king's process, or in doing their office, this is murder. And it is murder, if a watchman be killed in watching, and doing of his office; for in those cases the law does construe the offence, not only as done to the person that is slain, but to the office of execution of justice, or the keeping of the peace, which the law has imposed upon him that was slain, and for the offender by killing of this man, has done as much as in him lies, to restrain the execution of justice, or to hinder the preservation of the peace.' (underlining supplied). See also Anon (1584), see App C(a).

${ }^{567}$ Pulton, n 42, p 125 referred to a case in 1328, see n 411. The issue of neglect does not appear to have been covered by Lambard, $\mathrm{n} 40$, in his 1581 edition but was mentioned in the $1599 \mathrm{ed}, \mathrm{p} 236$ as a form of implied malice.

568 Ibid, pp 124-5.

569 Ibid, p 123 'But if a man being in doing of an unlawful act, as casting of stones into a highway, where men do usually pass, or shooting of arrows into a market, or other place, wither men do usually resort, or fighting at barriers, or running at tilt, or jousts with others without the king's commandment, whereby a man is slain: in these last specified cases it is felony at the least, viz. manslaughter if it be not murder; for the offendor being doing of an unlawful act by his own will, the law will construe his meaning and will therein by the success of the act.'

${ }^{570}$ As Holdsworth noted, $\mathrm{n} 65$, vol 3, p 315, it was only by statute (24 \& 25 Vict (1861) c 100, s 11) that an attempt to murder was made a felony, another oddity of the early law.

${ }^{571}$ Ibid, p 125. The citation is Bracton, n 22, vol 2, p 384 'In crimes the intention is regarded, not the result. It does not matter whether one slays or furnishes the cause of death.'

572 Ibid, pp 124-6.

573 See n 558 (definition). Also Pulton, n 42, p 123 'And manslaughter, otherwise called chance medley, is when two do fight together upon the sudden, without any malice precedent, and one of them does kill the other...' See also Ibid, p 120.

574 Ibid, p 123.

575 (a) 'casts a stone at a bird or a beast, and another man or woman passing by the way is stricken thereby and dies'; (b) 'be in felling of a tree, and the same tree, or some arm or bough thereof falls upon another person, and kills him'; (c) 'do shoot an arrow at a butt, or other mark, and another passing that way is killed therewith'; (d) 'do let a stone or a piece of timber fall from a house, or out of a window, and another passing that way is killed by it.' (e) 'the schoolmaster do in a reasonable manner beat his scholar for correction only, or the master his servant, and after the scholar or servant dies'; (f) 'two men do by consent wrestle with one another, and one gives the other a fall and hurts him, whereby he dies'; (g) 'one does play with the other at hand sword by consent, and one of them gives the other a blow, or thrust, whereby he dies'; (h) 'a man do cast wood, stone or other thing from a cart, a house, or from a window, hovel, or rick, and another is oppressed therewith, and dies'; (i) 'a man being in due and convenient time doing any thing that might breed danger to passengers thereby, do cry out with so loud and audible voice to give warning thereof, that any other which travels that way may hear and fly the peril, and yet one careless and not respective of his life and safety is oppressed therewith'; (j) 'two men do run at tilt, joust, or fight at barriers together by the king's commandment, and one of them does kill another.'

${ }^{576}$ Pulton, n 42, p 123 'But in this case it is to be considered, whether he that committed this homicide by misadventure was then busied in a thing that was lawful, or unlawful...'
} 
Pulton indicated that it was justifiable to kill:

- pursuant to due legal process; ${ }^{577}$

- a felon resisting arrest; ${ }^{578}$

- a person arrested, being taken to prison, who fled; ${ }^{579}$

- a person escaping from prison. ${ }^{580}$

Also, when the following Acts applied:

- $\quad$ Act of 1293 (trespasser in a warren etc, see 17);

- Act of 1532 (attempting to murder, rob or burgle, see 20(d)) $;^{581}$

- Act of 1553 (unlawful assembly, see 22). ${ }^{582}$

(e) Excusable Killing

Pulton indicated that it was excusable to kill a person:

- in self defence; ${ }^{583}$ or

- defending another; ${ }^{584}$ or

- defending one's house - including against those who came to burn it ${ }^{585}$ or to rob ${ }^{586}$ Pulton referred to Semayne (1604); ${ }^{.57}$

- $\quad$ assaulting one in one's own house, $;^{588}$

- defending one's master; ${ }^{589}$

- a robber. $^{590}$

577 Ibid, p 120.

${ }^{578}$ Ibid. 'A sheriff, or bailiff, or any other which has warrant to arrest a man indicted of felony, may well justify the killing of him, if he will not suffer himself to be arrested, but that he does stand at his defence, in such manner, that the officer and his assistants cannot arrest him without killing of him. And in this case the officer shall be discharged without the king's pardon: for this is homicide by justice done upon him, who refuses to yield unto, and submit himself to the justice of the law. And every person, as well he that has no warrant, as he that has, may apprehend a felon: and if he will not yield to be arrested, but stand to his defence, or flee, the pursuer may kill him without blame, the arrest being for felony, and therein he shall commit homicide by justice.' Pulton referred to a case in 1348, see n 441 and to Fitzherbert, n 30, title Corone, no 261.

${ }^{579}$ Ibid, p 121 'As any man may justify the killing of another before arrest, if he will not yield, so may he do after arrest, if there be any inevitable necessity therein: as if an offender be arrested for felony, and when he is in leading towards the gaol he breaks from those that do conduct him, and flies away, and his conductors do pursue him so, that they cannot apprehend and take him without killing of him: In this case, if they do kill him, this is homicide by justice, for that the offender would not yield to the trial and justice of the law.' Pulton referred a case in 1348 (see $\mathrm{n} 441$ ) and to Fitzherbert, n 30, title Corone, no 288.

${ }^{580}$ Ibid, 'As a man may kill an offender before arrest, or after arrest if he will not yield, so in some case a man may kill him that is under arrest and in prison: as a gaoler came in the night with a lantern in his hand to see his prisoners, who before his coming had broken their irons, and stood all ready to kill him, and did beat and evil intreat him, and he having a hatchet in his hand, therewith slew two of them, and escaped from the residue: this was adjudged to be well done, and to deserve no punishment, for this was by the gaoler homicide by justice, to kill them who attempted to kill him, and who endeavored to escape the trial and justice of the law. Pulton, n 42, p 121, referred to a case in 1348, see $n 441$.

581 Ibid.

582 Ibid.

${ }^{583}$ Ibid, p 120 'By necessity, as when one man kills an other with grief and sorrow of mind, thereby to deliver himself, or that which is his, or some other persons, or things which he is bound to deliver from further peril, which he or they cannot otherwise escape.' Also, p 121 'Homicide upon necessity...is when one man kills an other with grief of mind, and sorrow of heart, and being enforced unto it, thereby to deliver himself, or that which is his, or some other persons that he is bound to defend from further peril, which otherwise cannot be avoided, and this homicide is by law justifiable [it should read 'excusable']'.

584 Ibid, n 522 'some other persons.'

${ }^{585}$ Ibid, $\mathrm{p}$ 121. 'As of one or divers persons come to a man's house to burn his house, but he or they do not burn it, if the owner of the house or any of his servants do shoot forth of the house, and kill the offenders or any of them, this is homicide by necessity in defence of his house, and not felony.' Pulton referred to a case in 1352 , see $n 450$.

${ }^{586}$ Ibid, p 121 'if one or more come to a man's house to rob him, and the owner or any of his servants, or company being with him in the house do kill the offenders, or any of them, this is homicide by necessity in defence of his goods, and therefore justifiable: for a servant may justify the killing of an other in defence of his master's person, or house, if the offence cannot otherwise be avoided.'

${ }^{587}$ Semayne (1604), see App E(c). Pulton also referred to a case in 1352, see n 450.

588 Pulton, n 42, p 122: 'But if one man do come in day time to another man's house, and do make an assault upon him in his own house, and do fight with him, if the owner of the house do slay the assailant in his own defence, the owner of the house shall forfeit his goods, and be driven to sue for the king's pardon [on the basis of self defence], except that it be proved and found, that the assailant came also to rob the other in his house.' [in which case it was justifiable and so no crime was committed]. See also 21 Hen 7 pl 50 fo 39a (1505), Seipp no 1505.050. Seipp noted the dictum of Fyneux CJKB: if one were in his house, can he heard (oyent) that such a one wanted to come to his house to beat him, he could well make an assembly of folk (genz) among his friends (amis) and neighbours (voisins) to assist him, and to aid in safeguarding his person, but if one was threatened (menace) that if he came to such a market, or into such a place, he would be beaten there, in this case he cannot make an assembly of folk (gens) to assist him to go there to safeguard his person, because he does not need (ne besongne) to go there, and he could have a remedy (against one who threatened him) by surety of the peace, but the house of one is to him his castle and his defence, and where he properly ought to remain, etc. (italics supplied).

589 Ibid. Pulton referred to a case in 1352, see ns 451.

${ }^{590}$ Ibid. 'if one do attempt to rob another being out of his house, and pursues him to that end, the true man may kill the offender, and shall be discharged thereof...' Pulton referred to a case in 1352, see $\mathrm{n} 451$. 
In the case of self defence, Pulton indicated that the burden of proof was high: the killing must be unavoidable. ${ }^{591}$ It may also be noted that Pulton was one of the first legal writers to confuse the distinction between justifiable homicide (where no crime was committed) and excusable homicide (where it was, but it was pardoned). This confusion may have been due to the fact that the Act of 1532 (see 20(d)) specified that the killing of those who attempted to murder, rob or burgle, was justifiable. However, it limited this to those who attempted to:

- $\quad$ rob (or murder) any person in (or near) any common highway, cartway, horseway or footway; or

- $\quad$ rob (or murder) any person in their house; or

- break into a house at night.

Thus, where the robbery (or murder or burglary) was in another context, the killing of the same was still governed by the common law.

\section{In conclusion, Pulton added little to Lambard.}

\section{Dalton (1618-1746)}

Dalton, The Countrey Justice, was a popular work from when it was first published in 1618 until the final edition in 1746, when it was superseded by the (equally) popular text of Hawkins (see 31).

\section{(a) Homicide}

In the (second) edition of his work in 1619, Dalton stated:

Homicide most properly is, hominis occisio ab homine facta; [the killing by a man of a man]... ${ }^{592}$ Others do thus define or describe it: homicide is the felonious killing of one man by another within the realm, and living under the king's protection. 593

Dalton divided homicide into:

- $\quad$ intentional (voluntate) being murder or manslaughter (chance-medley);

- $\quad$ accidental (casu) being misadventure, whether it happen in doing a lawful or unlawful thing; and

- $\quad$ excusable (necessitate) being commanded (in the execution of justice), tolerated (for the advancement of justice 0 , in self defence (se defendendo) or prohibited.

It is a pity that Dalton reduced Bracton's 4 categories to 3 - by merging justifiable and excusable homicide - since this did not help for clarity. It is likely he may have followed Pulton (see 26).

\section{(b) Murder}

Dalton stated: ${ }^{594}$

murder is now construed to be, when one man upon malice pretended, prepensed, or precedent, does kill another feloniously viz. with a premeditate and malicious mind, whether it be openly, or privily done, this is felony of death (underlining supplied)

Dalton indicated that the malice could be express or implied, ${ }^{595}$ the latter occurring:

where one kills another without any provocation, the law implies and adjudges it to have proceeded of malice prepensed; ${ }^{596}$ Therefore if one suddenly, and without any show of quarrel, or offence offered, shall draw his

\footnotetext{
${ }^{591}$ Ibid, pp 122-3 'Homicide in a man's own defence, ought to be so great, and upon such necessity, that it must be esteemed to be inevitable, or otherwise it will not excuse: for here the killer of the man has not to do with a felon, as in some of the former cases, but with a lawful and true man, And it is not material whether the person that did kill, or the person which was slain did begin the fray, but the whole matter will consist upon the inevitable necessity, without the which the killing is by no means excusable. And therefore the true definition of homicide in his own defence is, when the assailant does make a fray, or offer force to the defendant, and does strike him, and the defendant does flee so far as he can for saving of his life, so that he is come to a strait, beyond the which he cannot fly, and the assailant does continue his assault; whereupon the defendant does strike the assailant, and does kill him, this is homicide in his own defence. For if the defendant could have avoided the assailant, and did not, but when the assailant did strike him, he did strike him again and killed him, this is felony in the defendant.' Pulton referred to a case in 1369, see $\mathrm{n} 431$.

592 Dalton, $\mathrm{n} 43$, p 215 continued 'for if a man be killed by a beast (as a horse or dog) or by any other thing or mischance, although that be hominis cedium (of which two words homicide is derived) yet in such cases it is not aptly nor usually said that homicide is committed, but only a man is said to be slain.' ${ }^{593}$ Dalton cited Lambard (see 24). He also stated, p 215: 'whether he that is slain, be an alien, or a denizen; an englishman, or stranger, it makes no difference (if he live under the $\mathrm{k}$ [ing's] protection.'

594 Dalton had previously stated, n 43, p 217 'Of old time every killing of one man by another, was called murder (of the effect) because death ensued of it; afterward murder was restrained to a secret killing only, and therefore Bracton [see 13] and Britton [see 16]in their definition of murder, called it, occulta occisio nullo praesente etc. But since murder has been and is taken in a middle degree neither so largely as it first was, nor so narrowly as Mr Bracton and Britton speaks of it...' As to the first sentence, this would not seem correct. The Anglo-Saxons distinguished premeditated from unpremeditated killing.

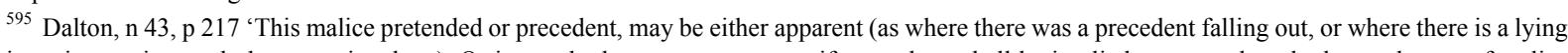
in wait or a time and place appointed etc). Or it may be less apparent or manifest, and yet shall be implied, presumed, and taken to be out of malice precedent, by the manner and circumstances thereof.'

${ }^{596}$ Dalton cited MacKalley (1611), see App B(c), at p $67^{\prime}$ 'As if a thief, who offers to rob a true man, kills him in resisting the thief, it is murder of malice prepense: or if one kills another without provocation, and without any malice prepense, which can be proved, the law adjudges it murder, and implies malice: for by the law of God everyone ought to be in love and charity with all men, and therefore when he kills one without provocation, the law implies malice...'. Coke very likely took these examples from Lambard, see 24. In this case it was also held, p 68(a)-(b) 'if any magistrate or minister of justice, in execution of his office, or in keeping of the peace according to the duty of his office, be killed, it is murder, for their contempt and disobedience to the king, and to the law, for it is contra potestatem regis et legis: and therefore, if a sheriff, justice of peace, chief constable, petit constable, watchmen, or any other minister of the king, or any who comes to their aid, be killed in doing of their office, it is murder for the cause aforesaid....reason requires that this killing and slaying shall be an offence in a highest degree of any offence of this nature; and that is voluntary, felonious, and murder of malice prepense.'
} 
weapon, and therewith kill another. Or if one shall be reading of some book, or otherwise busied, so as he saw not the party that shall stab or strike him (and he dies thereof) or shall be going over a stile etc and another shall kill him, such offenders shall suffer death, as in the case of wilful murder. ${ }^{597}$ (underlining supplied)

What is useful is that Dalton used the word 'provocation', which is the basis for the modern distinction between intentional killing which is not provoked (murder) and that which is (manslaughter). Dalton cited other examples of implied malice, viz. killing:

- $\quad$ a police officer in the execution of his duty; 598

- $\quad$ by a thief, attempting to steal from a person who resisted; ${ }^{599}$

- $\quad$ by neglect/cruelty; ${ }^{600}$

- by transferred malice; ${ }^{601}$

- $\quad$ pursuant to an unlawful act. ${ }^{602}$

Dalton also cited two examples of murder where there was no provocation (though he questioned whether, in fact, there had actually been provocation): ${ }^{603}$

- two playing at tables, falling out, one killed the other with a dagger, suddenly; ${ }^{604}$

- a husband, after words with his wife, suddenly struck her with a pestle, killing her. ${ }^{605}$

Also,

- $\quad$ A wounded B in a fight. Later, they met suddenly and fought again. B killed A. Dalton stated 'this seems murder, and malice shall be intended in B upon the former hurt, ${ }^{606}$ but now if A killed B this seems but manslaughter in A for his former malice shall be thought to be appeased by the hurt he first did to $B,{ }^{\prime 607}$

- $\quad$ two, in dispute with regard to a lawsuit, met suddenly and quarrelled about it. One killed the other. Dalton stated 'this seems murder. Tamen quaere.'[however, why] ${ }^{608}$

Thus, Dalton (following Lambard) cited 6 cases of implied malice: (a) unprovoked killing; (b) killing a police officer in the execution of his duty; (c) killing arising from an unlawful act; (d) killing by a thief (robber); (e) killing by transferred malice; and (f) killing by neglect/cruelty.

\section{(c) Manslaughter}

Dalton stated:

Manslaughter, otherwise called chancemedlye, is when two do fight together upon the sudden, and by mere chance, without any malice precedent, and one of them does kill the other... ${ }^{609}$ (underlining supplied)

Dalton provided various examples of hot blood:

- Hot Blood - Loan of Weapon. Two fell out on the sudden and fought. One broke his weapon and a stranger standing by (but not of their company) lent him a weapon. With it, he killed the other. Dalton stated: 'this is manslaughter as well in him that killed the other, as in the stranger, who lent him his weapon.' ;'610

- $\quad$ Hot Blood - Falls on Weapon. A and B fell out on the sudden and fought. A, being so fierce, ran upon the other's weapon and was killed. Dalton stated: 'yet this seems manslaughter in B for he should have fled to some wall or street etc. Quaere. And if $B$ had fled to a wall etc and A pursues him, and B perceiving that A would assault him,

\footnotetext{
${ }^{597}$ Dalton, n 43, p 217.

${ }^{598}$ Ibid, pp 217-8. 'To kill the sheriff, or any of his officers, in the execution of the king's process, or in doing their office, is murder in him that kills the officer...to kill any magistrate, or minister of justice, in the execution of their office or in keeping the peace (according to the duty of their office) is murder, and the law implies it to be of malice prepensed.' Dalton cited MacKalley (1611), see App B(c).

599 Ibid, p 218. Dalton cited MacKalley (1611), see App B(c). Also, Plowden, p 474, see n 524.

${ }^{600}$ Ibid. Dalton referred to a case in 1328 (see n 432) and a case in 1559, see App B(e). In respect of these examples of neglect, Dalton stated, p 219: 'In these last three cases, voluntas reputabitur pro facto, [the intent was taken for the deed] death ensuing thereupon; for it may plainly appear, that they had a will and meaning of that harm which followed, which will in them does amount to malice, and so makes their offences to be murder: and in such cases where death ensues, nihil interest utrum quis occidat, an causam mortis praebeat.' [see n 571].

${ }^{601}$ Ibid, p 220. Dalton cited Saunders \& Archer (1575), see App G.

${ }^{602}$ Ibid. 'in all cases where a man comes or goes about to do any thing unlawful, as to kill, beat, or disseize another, or to do any other trespass, and in doing this, he kills any man, this is murder.' This was in accordance with Brooke CJ in Herbert (1558), see 24.

${ }^{603}$ Ibid, n 43, p 219 'Quaere the reason why it should be murder in these two last cases, considering there appears no precedent malice, and that it was done upon the sudden, and upon provocation.'

${ }^{604}$ Ibid. 'in one Emeryes case, before Bromeley at the Assizes in Cheshire about $27 \mathrm{El}[\mathrm{iz}]$ [1584] as M Crompton reports'(spelling modernized). See also App B(d). This may be a mis-reference to the judge, or to the date, since Thomas Bromley was a justice of the King's Bench from $1544-53$ and CJ from 1553-5.

${ }^{605}$ Dalton referred to the 'Assizes at Stafford before Walmesley,43 Eliz.' [1601]. Thomas Walmisley was a Justice of the Common Pleas (1589-1612). See also App B(c).

${ }^{606}$ Dalton cited Lambard, see 24.

${ }^{607}$ Dalton, n 43, p 219.

608 Ibid.

${ }^{609}$ Ibid, p 222.

${ }^{610}$ Ibid. Dalton cited Crompton, n 39
} 
holds his weapon between them and A runs upon the weapon, and is slain, this is homicide in his defence;' [i.e. self defence] 611

- Hot Blood - No interval between Fighting. Two fought together on the sudden and then parted. Later, they met and fought again. One killed the other (or one fetched a weapon and killed the other). Dalton stated: 'these seem but manslaughter, for that is done all in one continuing fury, which was at the first without malice, and could not in so short a time be appealed, or assuaged.'; ${ }^{612}$

- Malice - Reconciled. Two bore malice towards each other. They were reconciled. Meeting again, they fell out on a new occasion. By agreement they immediately went into a field and fought, one killing the other. Dalton stated: 'this seems but manslaughter unless the respite or distance of time or place had been such, that by reasonable conjecture their heat might be assuaged.'

It was also manslaughter if a man killed another while performing an unlawful act (it was murder, if the unlawful act was intentional). Dalton stated:

But if man be doing of an unlawful act, though without any evil intent, and he happens, by chance, to kill a man, this is felony, viz. manslaughter at the least, if not murder, in regard to the thing he was doing, was unlawful. ${ }^{614}$

Dalton gave (standard) examples, in respect of:

- $\quad$ shooting arrows and casting stones; ${ }^{615}$

- tournaments; ${ }^{616}$

- games; 617

- $\quad$ throwing stones at birds. ${ }^{618}$

It is clear that there was uncertainty at this time, what the position was when, for example, persons were playing at sport (or a person throwing a stone or a workman a tile) and one killed another. Some treated this as pure accident. Others, on the basis that the act was unlawful, that it was manslaughter (on the basis that it was, effectively, negligent). Thus, the concept of negligence had not developed.

\section{(d) Accident}

Accidental killing only covered where the act resulting in the killing was otherwise lawful. Dalton stated:

Homicide by misadventure or misfortune, is when any person doing of a lawful thing, without any evil intent, happens to kill a man...And by our law now, this is no felony of death: for he shall have his pardon of course for his life and his lands; yet he shall forfeit his goods, in regard that a subject is killed by his means. ${ }^{619}$

Dalton gave as examples, killing arising from:

- a schoolmaster beating a child; ${ }^{620}$

- $\quad$ archery practice ${ }^{621}$

- a workman dropping tools; ${ }^{622}$

- $\quad$ a licensed tournament. ${ }^{623}$

\footnotetext{
${ }^{611}$ Ibid. The example, and the others, show the inadequacy of seeking to make legal rules of what should have been matters of fact.

${ }^{612}$ Ibid. Dalton cited Crompton, n 39.

${ }^{613}$ Dalton, $\mathrm{n} 43$, pp 222.

${ }^{614}$ Dalton, n 43, p 225 cited Staunford, see 23.

${ }^{615}$ Ibid. 'As shooting of arrows, or casting of stones in a highway, or other place where men do usually resort.'

${ }^{616} \mathrm{Ibid}$. 'So of fighting at barriers, or running at tilt or jousts without the king's commandment, whereby a man is slain and although it were by the king's commandment yet it was held felony by the justices, tempore [in the time of] H 8.' Dalton referred to a case in 1496, see $\mathrm{n} 471$ and to Brooke, $\mathrm{n} 31$, Corone, no 229 .

${ }^{617}$ Ibid 'Playing at hand sword, bucklers, football, wrestling and the like, whereby one of them receives a hurt, and dies thereof .....some are of the opinion that this is felony of death: some others are of opinion, that this is no felony of death, but that they shall have their pardon of course, as for misadventure, for that such their play was by consent, and again there was no former intent to do hurt, nor any former malice, but done only for disport, and trial of manhood.' Dalton referred to a case in 1496, see n 471 and to Crompton, n 39.

${ }^{618}$ Ibid. 'A man casts a stone at a bird, or beast, and another man passing by is slain therewith, quaere whether this be manslaughter, or by misadventure; the opinion of Fineux chief justice in [1496, see $\mathrm{n} 471$ ] is, that if a man cast a stone over a house, and kills a man, this is no felony, but misadventure. But Master Brooke abridging this case, says, it seems to be no law, but where the casting of a stone is lawful, as where a mason is untiling of a house etc but to cast it for pleasure, and not in lawful labour, seems to be felony.' Dalton referred to Fitzherbert, n 30, title Corone, nos 302 \& 354 . Also, to Brooke, $n$ 31, title Corone, no 229. 'and so was the opinion of M Bracton and M Staunford.' Dalton cited Bracton, see 13 and Staunford, see 23.

${ }^{619}$ Dalton cited Staunford, see 23 and Fitzherbert, n 30, title Corone, nos 69, 302 \& 354.

${ }^{620}$ Dalton, n 43, p 224 'if a schoolmaster, in reasonable manner beating his scholar for correction only: or a man correcting his child, or servant in reasonable manner; and the scholar, child, or servant happen to die thereof....'

${ }^{621}$ Ibid. 'So if a man shooting at butts, pricks, or other lawful mark, and by the shaking of his hand, or otherwise against his will, he kills one that stands or passes by.' Dalton cited a case in 1496, see n 471 and the Case of Thorns (see n 495). See also a case in 1329, see n 428.

${ }^{622}$ Ibid. 'So if a carpenter, mason, or other person does throw or let fall a stone, tile, or piece of timber from a house, or wood, or other thing from a cart etc (and gives warning thereof) and another is killed thereby against his will.' Dalton cited a case in 1496, see n 471 and Brooke, title Corone, no 59. Also, 'So if a labourer that is selling, or cropping of a tree, and the same or part thereof falls and kills a man.' Dalton cited the Case of Thorns (see $\mathrm{n} 495$ ), Fitzherbert, n 30, title Corone 398 Also, 'So if the head of his hatchet, or other tool falls from him, and happens to kill one standing by.' Dalton also cited the Book of Deuteronomy, see 7(ii)
} 


\section{(e) Justifiable Killing}

Dalton provided a rationale for justifiable killing ${ }^{624}$ and indicated that it was justifiable to kill a person:

- $\quad$ pursuant to due legal process; ${ }^{625}$

- $\quad$ resisting arrest; ${ }^{626}$

- $\quad$ escaping, when being taken to prison; ${ }^{627}$

- $\quad$ escaping from prison; ${ }^{628}$

- a thief, robber or murderer; ${ }^{629}$

- defending one's house; ${ }^{630}$

- $\quad$ assaulting a person in his house. ${ }^{631}$

Also, where the following applied, the:

- Act of 1293 (trespasser in a warren etc, see 17); ${ }^{632}$

- Act of 1532 (attempting to murder, rob, burgle, see 20(d)). ${ }^{633}$

- Act of 1553 (unlawful assemblies, see 22); ${ }^{634}$

Because Dalton merged justifiable and excusable killing, he cited the last above 3 examples as ones of excusable killing. However, they were of justifiable killing. That is, no crime was committed. Dalton also noted, in the case of excusable killing, that: 'there must be an inevitable necessity that the offender could not be taken etc without killing him.' 635

\section{(f) Excusable Killing}

Dalton stated that killing was excusable on the basis of necessity:

when one kills another in the necessary defence of himself, or his [family and servants], thereby to deliver himself, his possessions, or his goods, or some other persons, which he is bound to defend from peril, and which cannot otherwise escape. ${ }^{636}$

\footnotetext{
${ }^{623}$ Dalton, n 43, p 225 'so if men shall run at tilt, joust, or fight at barriers together by the king's commandment, and one of them does kill another.' Dalton cited a case in 1496, see $\mathrm{n} 471$ and Brooke, n 31, title Corone, no 229.

${ }^{624} \mathrm{Ibid}$, 'Sometimes... the justice of law tolerates and suffers a man to be slain for the necessary execution and advancement of justice, which otherwise should be left undone: and in such case, the law of the land imputes it not as a fault to him that shall so kill a man, but freely discharges him thereof without the king's pardon.'

${ }^{625}$ Ibid. Dalton (following Staunford), indicated that a person could not exercise private revenge. At p 227 'if a stranger, being not thereto lawfully deputed shall (upon his own authority) put to death an offender that is condemned to die, this is felony.'

${ }^{626}$ Ibid, p 227 'As a sheriff, bailiff or any other person who has a lawful warrant to arrest a man indicted of felony, may well justify the killing of him, if he will not suffer himself to be arrested, and yield himself, and that they cannot otherwise take him.' Dalton cited Fitzherbert, $\mathrm{n} 30$, title Corone, $\mathrm{p} 261$ and Staunford. Also 'so every person whatsoever without any warrant may apprehend a felon upon hue and cry, or otherwise; and if he will not yield to be arrested, but shall resist, or fly, the pursuer may kill him without blame.' Herewith also agrees the Doctor and Student, lib 2 cap 41 [see $\mathrm{n} 482$ ] saying, if any person that is no officer, would arrest a man that is outlawed, abjured, or attainted of murder, or of any other felony, and such offender shall disobey the arrest, and by reason of that disobedience he is slain, the other shall not be impeached for his death; for it is lawful unto every man to arrest, and take such persons, and to bring them forth, that they may be ordered according to the law.'

${ }^{627}$ Ibid. 'An offender in felony is led towards the gaol, and breaks away from those that conduct him, and makes resistance or flies; his conductors may justify to kill him, if they cannot otherwise take him again.' Dalton cited Fitzherbert, n 30, title Corone, nos 288 \& 328.

${ }^{628}$ Ibid. 'A prisoner in the gaol attempts to escape, and having broken his irons, strikes the gaoler (coming in the night to see his prisoners) and the gaoler slays such a prisoner, this is no felony'. Dalton cited a case in 1348, see n 441. Also, 'The sheriff, or his bailiff, or other officer comes (by virtue of the king's process) to arrest another for debt, or trespass, who makes resistance, and thereupon is slain by such officer, or any of his company, this has been taken to be no felony, tamen quaere. Dalton cited Staunford, see 21, Crompton, n 39 and St German, see n 482.

${ }^{629}$ Ibid, p 229. 'To kill a thief or murderer in the defence of my person, my house, or goods, was no felony, but justifiable by the common law, before the statute of 24 Hen 8 c 5 [the Act of 1532, see 20(d)].' This Act also covered a robber, although Dalton failed to mention this.

${ }^{630}$ Ibid. 'if one or more come to burn my house, I, or any of my servants, may justify to shoot forth of my house at them, and to kill them, for such intent of theirs is felonious. But if a man shall forcibly get and keep possession of a house and the other shall come in the night and fire this house, they within cannot justify to shoot and kill him, or any of his company, for that they in the house were there unlawfully.' Dalton cited a case in 1352 , see $\mathrm{n} 450$.

${ }^{631}$ Ibid. 'If one comes (in the day time) to my house, to beat me, and does make an assault upon me in my house and fights with me, and I kill him in defence of my person, yet in this case I shall forfeit my goods, and must have the king's pardon, except it be found, that the assailant come with a felonious intent to kill or rob me.' [if so, the Act of 1532 would apply, see 20(d)]. 'And if one comes in the day time, or in the night, to enter into my house, pretending title thereto and to put me out of my possession, and I kill him, this seems to be manslaughter in me.'

${ }^{632}$ Ibid, pp 230-1.

${ }^{633}$ Ibid, p 228 'To kill an offender, which shall attempt feloniously to murder or rob me in my dwelling house, or in or near any highway, horseway or footway, or that shall attempt burglary, to break my dwelling house in the night; this is justifiable by my self, or by any of my servants, or company.' Dalton cited the Act of 1532, see 20(d).

${ }^{634}$ Ibid, p 228. 'Rioters, and such as shall make any forcible entry, or detainer, against the statutes, if they shall resist the justices of peace, or other the king's officers, or shall not yield themselves, but shall stand at their defence, when the justice of peace, or other officer shall come to arrest, or remove them, of any of them happen to be slain, this is no felony in the justice of peace, or officer, or in any of their company that killed such rioters.'

${ }^{635}$ Ibid, p 228.

${ }^{636}$ Ibid. The reference to ' $h i s$ ' is unclear and remained until the last edition in 1746 . One assumes that it meant to refer to a man's family and servants. See also p 229.
} 
A servant could also defend his master. ${ }^{637}$ However, in both cases, this was only excusable, where inevitable. ${ }^{638}$ A pardon was also required. ${ }^{639}$ As to defence of one's goods, Dalton stated:

In the defence of the possession of my goods, I may justify to beat him that shall wrongfully take them from me: but I cannot justify to kill him, except he be a thief. ..to kill a true man in defence of my house, lands, or goods, that is manslaughter (at least) as it seems. ${ }^{640}$

This statement reflected a distinction, subsequently emphasised by legal writers, that it was not excusable to kill a trespasser.

In conclusion, Dalton's work was popular and much cited until the last edition (in 1746) although it was superceded, to a considerable extent in the $18^{\text {th }}$ century, by Hawkin's work which commenced in 1716-21. It was a good summary of the law at the time and indicates problems in respect of:

- $\quad$ premeditation as a requirement of murder;

- $\quad$ the mixing of justifiable killing (which was no crime), with excusable killing (which was, but for which a pardon was given);

- uncertainty as to whether accidental unlawful killing was manslaughter or an accident;

- $\quad$ uncertainty as to whether negligent unlawful killing was manslaughter or murder.

\section{Coke (1641)}

Coke - in his Institutes of the Laws of England (1628-41) - stated various propositions on the law of homicide which were to be cited by legal writers, and the courts, up to present times.

\section{(a) Murder - Premeditated Malice}

Coke noted that the word 'murder' derived from the Anglo-Saxon word 'mord' $\left[\right.$ morth] ${ }^{641}$ which seems a reasonable supposition. ${ }^{642}$ Coke also provided the classic definition of murder:

Murder is when a man of sound memory, and of the age of discretion, unlawfully kills within any country of the realm any reasonable creature in rerum natura under the king's peace, with malice forethought, either expressed by the party or implied by law... ${ }^{643}$ (spelling modernised and underlining supplied)

Extracting references to defences (insanity and the age of criminal responsibility) as well as to issues of jurisdiction ('any county of the realm') which do not need to be in the definition, Coke's definition was:

Murder is when a man... unlawfully kills... any reasonable creature in rerum natura under the king's peace, with malice forethought...

Coke had also provided a definition of murder in an earlier volume of his Institutes (volume 1 published in 1628) which stated:

Murder is when one is slain with a man's will [i.e. intention], and with malice prepensed or forethought. Homicide, as it is legally taken, is when one is slain with a man's will, but not with malice prepensed. Chance-medly, or per infortunium, is when one is slain casually, and by misadventure, without the will of him that does the act, whereupon death ensues... ${ }^{644}$

Therefore, murder was when a person unlawfully killed: ${ }^{645}$

\footnotetext{
${ }^{637}$ Ibid, p 230 'the servant may justify the killing of another, in defence of his master's person or house, if the hurt cannot be otherwise avoided.' Dalton cited Brooke, n 31, title Coron, n 63. 'Also the servant may justify the killing of him, who robbed and killed his master.' See also a case in 1352 , see $n$ 451 .

${ }^{638}$ Dalton, n 43, p 229 'if one kill a true man, in defence of his person, there ought to be so great a necessity, that it must be esteemed to be inevitable, or otherwise it will not excuse: and therefore he that shall be assaulted by a true man, must first fly as far as he can, and until he be letted [prevented] by some wall, hedge, ditch, press of people, or other impediment; so as he can fly no further without danger of his life, or of being wounded or maimed...' Dalton cited Staunford, see 21.

${ }^{639}$ Ibid, p 225 'And yet in cases of misadventure, as also, where one kills another se defendendo, by the common law these offences were felony of death, and the offender should have died for the same; but now by statute such offendors are to have pardon for their life and lands, yet their goods remain forfeit as before (at the common law) ....in these cases of misadventure... as also where one kills another in defence of his person, they shall be discharged in this manner, viz. if they desire to purchase their pardon, they must, upon their trial, plead not guilty (and shall give in evidence the special matter) and then this special matter being found by verdict, they shall be bailed, and then they must sue forth a certiorari, to have this record certified to the Lord Chancellor of England, who thereupon shall make them a charter or pardon of course under the great seal, without speaking to the king or suing to the king for it.'

${ }^{640}$ Ibid, p 230

${ }^{641}$ Coke, n 44, vol 3, p 48. See also vol 1, $287 \mathrm{~b}$ 'Murder comes of the Saxon word mordreu. [i.e. morth]' Coke also stated: 'All the ancient authors...of old time defined murder to be occulta hominis occisio etc when it was done in secret, so as the offender was not known: but now it is taken in a larger sense.' Ibid, p 48.

${ }^{642}$ The alternative interpretation is to derive the word 'murder' from the murder fine. However, see $\mathrm{n} 88$.

${ }^{643}$ Coke continued 'so as the party wounded, or hurt, etc die of the wound, or hurt, etc within a year and a day after the same.' This rule has been abolished (see 3) and so it will not be further discussed.

${ }^{644}$ Coke, n 44, vol 1, 287b. See also 391 where Coke also noted that the word 'felony' covered all of murder, homicide (including self defence) and chance medley save that, murder resulted in corruption of blood but the others did not. Coke stated: 'For such of these crimes for which any shall have this judgment, to be hanged by the neck till he be dead, he shall forfeit all his lands in fee simple, and his goods and chattels: for felony by chance-medley, or se defendendo... he shall forfeit his goods and chattels, and no lands of any estate of freehold or inheritance.'

${ }^{645}$ Ibid, vol 3, p 47 'As by poison, weapon sharp or blunt, gun, crossbow, crushing, bruising, smothering, suffocating, strangling, drowning, burning, burying, famishing, throwing down, citing a dog or bear etc to bite, or hurt etc whereof death ensues, laying a sick man in the cold etc' (spelling modernised). It is interesting to note that the modus operandi of murder has not changed through the centuries. J Briggs et al, Crime and Punishment in
} 
- within any county of the realm;

- $\quad$ any reasonable creature in rerum natura;

- under the king's peace;

- with malice forethought (express or implied).

The first 3 issues may be dealt with briefly since the law has been clarified since Coke's time:

- County of the Realm. This related to the jurisdiction of the English courts. Thus, murder arising from a duel abroad was not within the jurisdiction of the king's courts although it was within (Coke asserted) that of the Court of Chivalry. In the case of killing at sea, Coke discussed the admiral's jurisdiction. Jurisdiction is not considered further since the Court of Chivalry no longer exercises criminal jurisdiction and murder abroad (including on the sea) is now contained in legislation; ${ }^{646}$

- Reasonable Creature in Rerum Natura. In Coke's time, a child in the womb was not regarded as a human being. However, the killing of an infant was murder. So too, any other person, regardless of their nationality. ${ }^{647}$ Today, therefore, the word 'person' would replace 'reasonable creature in rerum natura'. The words 'in rerum natura' were used by Coke, following Bracton, to mean a person 'in esse' (in existence) ${ }^{648}$ and not to exclude a monstrous or deformed child; $;^{649}$

- King's Peace. By the time Coke wrote, it had been accepted that the king exercised criminal jurisdiction (his 'peace') throughout the realm. ${ }^{650}$ However, Coke's reference to 'peace' also referred to two cases where it was justifiable to kill, viz. (a) a foreign enemy, in war; ${ }^{651}$ (b) when martial law applied. This latter concept underwent a change in meaning over time.

(a) Military Law. At first, martial law comprised a reference to military law in respect of the armed forces. However, after 1688, legislation started to govern the matter. Today, the armed forces are regulated by distinct legislation and, so, the concept of martial law is no longer relevant vis-à-vis them; ${ }^{652}$

(b) Civilians subject to Military Law. The imposition of martial law also referred to the situation where civilians became subject to military law - including the jurisdiction of military courts, with their right to impose the death penalty and other military punishments.

- In earlier times, martial law covered the situation of war. ${ }^{653}$ When the king raised his standard on the battlefield within the realm, the courts were 'shut'. The common law (the law of the land) no longer applied. Instead, military law (martial law) applied and, as commander of his army, the king (or his appointee) exercised the power of life and death; ${ }^{654}$

- This included the right to order the execution of those on the battlefield who opposed the king's standard. ${ }^{655}$ Legitimately, they could be killed on the battlefield - but not after the

England (1996), p 246 'Despite the increasing availability of firearms, almost 90 per cent of murders are committed by the time-honoured means of sharp or blunt instruments, hitting, kicking or strangling, burning, drowning or poisoning. The only truly modern method of causing death recorded in the current returns is using a motor vehicle deliberately to kill - a dozen or so cases a year.' Coke noted that perjury was no longer a form of killing in law ('not holden for murder at this day'). Ibid, p 48.

${ }^{646}$ Ibid, pp 48-50.

${ }^{647}$ Coke, n 44, vol 3, p 50 'As man, woman, child, subject born, or alien, persons outlawed, or otherwise attainted of treason, felony or premunire, Christian, jew, heathen, turk, or other infidel, being under the king's peace.' Cf. $\mathrm{n} 468$ and the views of Brooke and Mountford.

${ }^{648}$ For references by Bracton, see Bracton online, see n 22. See also Lambard (1599 ed), n 40, p 229; Dalton, n 508 , p 211 (in esse (sc in rerum natura) and Hale, n 45, vol 1, p 433 (unborn child not in rerum natura). Cf. Bracton, n 22, vol 2, p 341 'If one strikes a pregnant woman or gives her poison in order to procure an abortion, if the foetus is already formed or quickened, especially if it is quickened, he commits homicide.' Cf. Coke, $\mathrm{n} 44$, vol 3 , $\mathrm{p} 50$.

${ }^{649}$ Coke knew the concept of a 'monstrous child', since he made reference to the same elsewhere, see Coke, n 44, vol 1, $3 b$ 'A monster born within lawful matrimony, that has not a human shape, cannot purchase, much less retain any thing.'

${ }^{650}$ Thus, the coronation charter of Henry I (published in 1100) stated 'I establish lasting peace throughout the whole of my realm and enjoin that it be maintained henceforth.' See also Robertson, n 18, p 128 and McBain, n 215, p 15.

${ }^{651}$ This was a common law proposition which was stated as early as Bracton (see n 360, a just war) and would have applied, in practice, since Anglo-Saxon times, not least since all Anglo-Saxons were subject to the trinoda necessitas, which included defending the realm.

652 Military law did not derive from the common law. Instead, it was a Crown prerogative, emanating from the Crown's right to declare (and levy) war and peace. At a lesser level, this prerogative covered the control of the army, when encamped and on the battlefield. Here, the Roman concept of the military commander having supreme power over life and death likely became transmuted, in England, into one of the sovereign having the same. However, when the sovereign no longer went into every battle, then, in England, the supreme commander was the earl marshall (an office which existed since the $12^{\text {th }}$ century and which was held hereditarily by the Duke of Norfolk since 1672). He could establish a court (court of chivalry or court marshall or marshall's court) to punish infractions of military discipline, which included capital punishment. When standing armies were introduced after 1688, and legislation dealt with courts martial, the court of chivalry fell into abeyance. See generally, GS McBain, Abolishing Obsolete Crown Prerogatives relating to Martial Law, Conscription \& Billeting. (2012) Int. Law Research, vol 1, no 1, 18-9. See also Manual of Military Law (1929, rep 1939), pp 6-14.

${ }^{653}$ It also covered military action in a foreign war. In the case of foreign wars, it seems likely the English courts were treated as (and were) open. LO Pike, Year Books of the Reign of King Edward the Third, Year XIV [1340] (HMSO, 1888) p xvii (case in 1340, the realm is in a state of peace when its forces are engaged in war, if not waged on the soil of the realm).

${ }^{654}$ In practice, in earlier times, many 'prisoners of war' were also likely killed after the battle or executed by courts martial shortly thereafter. See McBain, n 652, p 27.

${ }^{655}$ The commander's power of life and death was, likely, taken from Roman law. As Gibbon noted 'In his camp the general exercised an absolute power of life and death; his jurisdiction was not confined by any forms of trial or rules of proceeding, and the execution of the sentence was immediate and 
standard had been lowered. ${ }^{656}$ Martial law covered not just a British subject but also an alien subject to local protection and an enemy (hostis, inimicus). All of them could be executed on the battlefield pursuant to it; ${ }^{657}$

- $\quad$ As it is, the Petition of Right 1627 (still extant) - as well as Magna Carta, chapter 29 (still extant) ${ }^{658}$ - prohibited martial law applying to civilians in peacetime ${ }^{659}$ and the former likely also prohibited it in wartime as well. In a previous article, it has been asserted that martial law should be abolished (it has never been applied in England and Wales since, at least, 1688). ${ }^{660}$

Today, martial law no longer applies, leaving only the killing of a foreign enemy in war time as being justifiable, pursuant to Bracton's formulation of the common law.

As to malice aforethought, Coke stated:

Malice prepensed is, when one compasses [conspires] to kill, wound, or beat another and does it sedato animo. ${ }^{661}$

[with a set purpose or intent]. This is said in law to be malice forethought, prepensed, malitia praecogitata. ${ }^{662}$

Coke indicated that the malice must be continuing:

It must be malice continuing until the mortal wound, or the like be given. Albeit there has been malice between two, and after they are pacified and made friends, and after this upon a new occasion fall out, and the one kills the other; this is homicide, but no murder, because the former malice continued not...

If two fall out upon a sudden occasion, and agree to fight in such a field, and each of them go and fetch their weapon, and go into the field, and therein fight, the one kills the other; here is no malice prepensed, for the fetching of the weapon and going into the field, is but a continuance of the sudden falling out, and the blood was never cooled. But if they appoint to fight the next day, that is malice prepensed. ${ }^{663}$

Stephen noted that Coke, in his analysis, added little to what prior legal writers had stated. ${ }^{664}$ Further, Stephen pointed out the flaw in Coke's definition of premeditated malice being done 'sedato animo', stating, 'the mind may be just as sedate in executing an intention suddenly conceived, as in executing an intention of long standing.' 665

\section{(b) Murder - Implied Malice}

Coke, following Lambard, cited instances where malice was implied:

- Unprovoked Killing. 'if one kills another without any provocation of [on] the part of him, that is slain, the law implies malice;'

- Killing an Officer. ${ }^{667}$ 'if a magistrate or known officer, or any other, that has lawful warrant, and in doing, or offering to do his office, or to execute his warrant, is slain, this is murder, by malice implied by law, as the sheriff, justice of the peace, undersheriff, chief constable, petit constable, or any other minister of the king. If a man kill a

without appeal.' See E Gibbon, The History of the Decline and Fall of the Roman Empire (John Murray, 1855), vol 1, p 199. See also Digest, $\mathrm{n}$ 182, bk 48.3.9 Venuleius Saturninus, Duties of Proconsul, bk 1 'In the case of soldiers, the custom is observed that if they commit any offense, they are handed over to the [commander] under whom they will be serving; and he who takes over an army has also the right of punishing private soldiers.' This seems to have been similar in Anglo-Saxon law, see E Samuel, An Historical Account of the British Army (1816), p 7 (heretochs). A British subject, or one who otherwise owed allegiance to the king, who opposed the king's standard also committed the crime of high treason. See GS McBain, Abolishing the Crime of Treason (2007) 81 ALJ 94-134.

${ }^{656}$ The last occasion the standard was raised was in 1745. Those not killed on the battlefield were brought before the courts and tried for levying war under the Treason Act 1351. However, it does not appear that martial law as such was declared, since the courts were still open (as they were in WWI and WWII, for example, when martial law was also not declared).

${ }^{657}$ Coke, n 44, vol 3, p 11.

${ }^{658}$ Magna Carta (1297), ch 29 provides 'No free man shall be taken, or imprisoned, or be disseized of his freehold, or liberties, or free customs, or be outlawed, or exiled, or any other wise destroyed; nor will we pass upon him, nor [condemn] him (alternate wording 'deal with him') but by lawful judgment of his peers, or by the law of the land.' (italics supplied). For the Petition of Right 1627, see GS McBain, Modernising the Monarchy - in Legal Terms. Part 2 (2011) KLJ, vol 22(1), 95-118.

${ }^{659}$ See also Coke, $\mathrm{n} 44$, vol 3, p 52 'If a lieutenant, or other that has commission of martial authority, in time of peace hang, or otherwise execute any man by colour of marshall law, this is murder, for this is against Magna Carta cap 29 and is done with such power and strength, as the party cannot defend himself; and here the law implies malice. See generally, McBain, ns 652 \& 655. Also, GS McBain, Expanding Democracy -Transferring the Crown Prerogative to Parliament (2014) Review of European Studies, vol 6, no 1, pp 27-8.

${ }^{660}$ See McBain, n 652, pp 51-2. See also Manual of Military Law (1929, rep 1939), pp 4-5, 145-7.

${ }^{661}$ Coke, n 44, vol 3,p 50. See also Lewis \& Short, n 123 (definition of sedo) 'to settle, still, calm etc.'

662 Ibid.

${ }^{663}$ Ibid, p 51. See also Taverner (1616), see App B(a).

${ }^{664}$ Stephen, n 55, vol 3, pp 53-4 'On most of these heads [of discussion of homicide] Coke adds little or nothing to what has already been referred to as having been stated by earlier writers.' Also, 'It contains little which is not contained in Lambard, but Coke writes with an air of authority to which Lambard made no pretension, and his writings have in fact had extra-ordinary influence on every part of the law.' Stephen also indicated a point that one constantly notes with Coke, Ibid, p 56, n 1 'It will be found that he always writes latin when he is not quite sure of his own meaning.'

665 Ibid, p 55.

${ }^{666}$ Ibid. 'As if one kills another without any provocation on the part of him, that is slain, the law implies malice: whereof you may read.' Coke cited Mackalley (1611), see App B(c)

${ }^{667}$ Ibid, p 52. 
watchman doing his office, it is murder: so it is, if any, that come in aid of the king's officer, etc to do his office, be slain, it is murder'; 668

- $\quad$ Thief Kills. ${ }^{669}$ 'If A assault B to rob him and in resisting A kills A kills B this is murder by malice implied, albeit he never saw or knew him before...';

- Duress. ${ }^{670}$ 'If a prisoner by the duress of a gaoler, comes to untimely death, this is murder in the gaoler, and the law implies malice in respect of the cruelty...';

- $\quad$ Poison. ${ }^{671}$ 'the poisoning of any man ...implies malice.'

- $\quad$ Transferred Malice. Coke cited Bracton and referred to Gore (1611). ${ }^{672}$

In respect of unlawful killing, Coke cited the following examples:

- $\quad$ Stealing Deer. Coke stated:

- 'If the act be unlawful it is murder. As if A, meaning to steal a deer in the park of B, shoots at the deer, and by the glance of the arrow kills a boy that is hidden in a bush: this is murder, for that the act was unlawful, although A had no intent to hurt the boy nor knew not of him. [murder]

- But if $B$, the owner of the park had shot at his own deer, and without any ill intent had killed the boy by the glance of his arrow, this had been homicide by misadventure, and no felony;' ${ }^{673}$ [i.e. accident]

- $\quad$ Shooting Birds. Coke stated:

- 'if one shoot at any wild fowl upon a tree, and the arrow kills any reasonable creature afar off, without any evil intent in him, this is per infortunium: for it was not unlawful to shoot at the wild fowl: [ accident]

- but if he had shot at a cock or hen, or any tame fowl of another man's, and the arrow by mischance had killed a man, this had been murder, for the act was unlawful. ${ }^{674}$ [murder]

- $\quad$ Throwing Stones. Coke stated:

- 'If a man knowing that many people come in the street from a sermon, throw a stone over a wall, intending only to fear them [give them fear], or to give them a light hurt, and thereupon one is killed, this is murder; for he had an ill intent, though that intent extended not to death, and though he knew not the party slain. [murder]

- 'For the killing of any by misadventure, or by chance, albeit it be not felony, qua voluntas in delictis, non exitus spectatur, ${ }^{675}$ yet he shall forfeit therefore all his goods and chattels, to the intent that men should be wary so to direct their actions, as they tend not to the effusion of man's blood.' 676

These examples indicate the inadequacy of seeking to distinguish murder from accident on the basis of whether the act was unlawful or not, as opposed to considering these acts separately. Further, the result was draconian, as Coke's second example illustrates. Stephen later stated (in 1883):

This astonishing doctrine has so far prevailed as to have been recognised as part of the law of England by many subsequent writers, although in a modified shape given to it long afterwards by [Foster, see 34], who limits it to cases where the unlawful act amounts to felony. ${ }^{677}$ (italics supplied)

Stephen noted that the source of an 'unlawful act' was Bracton where he had said that where a man killed pursuant to an unlawful act, liability will be imputed (attributed) to him (see 13). One would agree. Stephen then argued that this passage did not mean that such a person would be punished with death. This is less certain. The problem is that this passage in Bracton can be read in various ways. ${ }^{678}$ Further, what Stephen fails to mention is that other writers besides Coke, had assumed that - if the act was unlawful and killing resulted - it was murder. ${ }^{679}$ One would agree with Stephen, however, that

\footnotetext{
${ }^{668}$ Coke cited Mackalley (1611), see App B(c).

669 Ibid.

${ }^{670}$ Ibid, p 52.

${ }^{671}$ Ibid, p 51.

${ }^{672}$ Ibid, p 50 'Si quis unum percusserit, cum alium percutere vellet, in felonia tenetur.' See App G.

${ }^{673}$ Coke, n 44, vol 3, p 56.

${ }^{674}$ Ibid. Coke cited a case in 1329, see n 428 and a case in 1496, see n 471. Stephen, n 55, vol 3, p 57-8 asserted that Coke's dictum rested on 'authorities which do not support it.' However, Coke was merely following prior legal precedent, since Stephen failed to consider other writings. Baker, $\mathrm{n} 459$, pp 309-10 'It was no doubt such borderline cases as these, fortified by some expressions of Bracton, which gave rise to the doctrine that a killing in the course of an unlawful enterprise was murder.' One would agree. See also Plummer (1701), see App C(b), p 117 where Holt CJ stated: 'if two men have a design to steal a hen and one shoots at the hen for that purpose, and a man be killed, it is murder in both, because the design was felonious.'

${ }^{675}$ Quoting Bracton, see n 349.

676 Ibid.

${ }^{677}$ Stephen, n 55, p 57.

678 There was no authorised version of Bracton (although Thorne's edition, see $\mathrm{n} 22$, today is generally regarded as fairly authoritative). Therefore, it is possibly that Coke (and other early judges) were considering corrupted texts.

${ }^{679}$ See, for example, Herbert (1588), text to n 522 (any battery could be murder) and a Reading in 1520, see 20(b). Stephen's otherwise excellent analysis of the law on murder and manslaughter in his History (n 55, vol 3) is hampered by the fact that, although he quoted Lambard and Coke, he considered none of the cases of their time.
} 
this is doctrine was quite unsatisfactory. ${ }^{680}$ Finally, killing by neglect (which Dalton had treated as implied malice), Coke treated as an example of express malice, with the exception of duress by a gaoler. ${ }^{681}$ Also, when considering Coke, in respect of implied malice by way of an unlawful act, Stephen noted an issue which (he asserted) had been 'missed' by previous legal writers:

the rule that a difference in the degree of bodily violence intended to be inflicted may make the difference between murder and manslaughter. As the law now stands, if a man stabs another with intent to do him grievous bodily harm, $[\mathrm{GBH}]$ and in fact kills him, he is guilty of murder. If he intentionally strikes him a blow with his fist or with a small stick with no intention to inflict any great harm, and happens to kill him, he is guilty of manslaughter. I have found no trace of any such distinction in Coke or his predecessors. ${ }^{682}$

This would seem correct. In Coke's time, following Herbert (1588), intentional, unlawful, killing was murder and, following Brooke CJ, any unlawful battery leading to death, was murder. Further, Coke argued that even accidental, unlawful, killing was murder.

Thus, Coke cited 7 cases of implied malice: (a) unprovoked killing; (b) killing a police officer in the execution of his duty; (c) killing arising from an unlawful act; (d) killing by a thief (robber); (e) killing by transferred malice; (f) killing by cruelty/neglect (including the duress of a gaoler); (g) killing by poison.

\section{(c) Manslaughter}

Coke stated:

Homicide is called chancemedley, or chancemelle, for that it is done by chance (without premeditation) upon a sudden brawl, shuffling, or contention: for meddle or melle (as some say) is an ancient French word, and signifies brawl, or contention. 683

Coke accepted that homicide was a generic term and he also used the term 'manslaughter' to cover any homicide that was not murder (excluding only killing covered by an accidental lawful act or in the case of justifiable or excusable homicide) ${ }^{684}$ including chance medley ${ }^{685}$ of which he gave examples:

- Two meet together. Striving for the wall, one kills the other. This is manslaughter [because hot blood];

- If on a sudden occasion men went into the fields and fought and one killed the other. This was manslaughter and not murder because all that followed was but a continuance of the first sudden occasion 'and the heat of the blood kindled by ire was never cooled, till the blow was given, et sic de similibus.' [and likewise] ${ }^{686}$

As Stephen noted, Coke's examples (and indeed those of Lambard and Pulton) reflected the spirit of those times when men carried weapons as a matter of course and it was manly to use them on any insult.

- However, even then, the distinctions that the courts were making were highly artificial and the issue should not have been whether the killer had retreated as far as could prior to killing but whether - as a matter of fact and not law - he had been sufficiently provoked such that his killing should be reduced from murder to manslaughter;

- The issue, in many of the cases should also have been whether the killer was acting in self defence, regardless of whether the person retreated or not. If the law had been clearer on these matters, it is likely that those duels which, supposedly, were 'spontaneous' would have been suppressed more easily.

\section{(d) Accidental Killing}

Coke referred to accidental killing:

There is an homicide that is neither forethought, nor voluntary. As if a man kill another per infortunium, seu casu, that is homicide by misadventure. ${ }^{687}$... Homicide by misadventure, is when a man does an act, that is not unlawful,

\footnotetext{
${ }^{680}$ Stephen also noted, n 55, vol 3, p 60 that, while the law was intelligible in Coke's time when the use of deadly weapons was common 'it is obviously not intended to apply to the forms of manslaughter, which are common in our own day.' This applies, a fortiori, in modern times, when the unlawful carrying of guns and knives constitute crimes in themselves.

${ }^{681}$ Coke, $\mathrm{n} 44$, vol 3, pp 48 (laying a sick man in the cold, poison).

682 Ibid, pp 56.

${ }^{683}$ For his derivation of the word, see $\mathrm{n} 94$.

${ }^{684}$ Coke, n 44, vol 3, p 54 'Homicidium ex vi termni [homicide by force of the term] comprehends petit treason, murder, and that which is commonly called manslaughter; for homicidium est hominis caedium, and homicidium est hominis occisio ab homine facta [quoting Bracton, see text to $\mathrm{n} 344$ ]. Therefore the right division of homicide is: that of homicide, or manslaughter, some be voluntary, and of malice aforethought; as petit treason, and murder of another, and murder of himself... Of manslaughters some be voluntary [i.e. intentional], and not of malice aforethought: of these some be felony (as shall be showed hereafter) and some be no felony; of some be in respect of giving back inevitably in defence of himself, upon an assault of revenge: and some without any giving back; as upon the assault of a thief or robber upon a man in his house, or abroad: some upon the assault of one, that is under custody; as the sheriff, or gaoler assaulted by his prisoner. Some in respect that he is an officer or minister of justice, without any assault in execution of his office, or lawful warrant. And lastly, some homicides, that be no felony, be neither forethought, nor voluntary; as manslaughter by misadventure, per infortunium, or casu...'

${ }^{685}$ Ibid. 'Some manslaughters be voluntary [i.e. intentional], and not of malice forethought, upon some sudden falling out. Delinquens per iram provocatus puniri debet mitius [A delinquent provoked by anger ought to be punished more mildly]. And this for distinction sake is called manslaughter.' Coke also stated: 'There is no difference between murder, and manslaughter; but that the one is upon malice forethought, and the other upon a sudden occasion: and therefore is called chancemedley.' This is incorrect since manslaughter also covered homicide unless it was accidental pursuant to a lawful act or justifiable or excusable homicide.

686 Ibid.

${ }^{687}$ Ibid, p 56.
} 
which without any evil intent tends to a man's death. ${ }^{688}$

\section{(e) Justifiable Killing}

Coke gave examples of justifiable killing:

- defending oneself against a thief; ${ }^{689}$

- when a gaoler killed a prisoner attacking him; ${ }^{690}$

- when a person resisted arrest; ${ }^{691}$

- in the course of a licensed martial game. ${ }^{692}$

\section{(f) Excusable Killing}

In the case of excusable killing, Coke mentioned the right to self-defence, giving the following examples:

if A be assaulted by B and they fight together, and before any mortal blow given A gives back, until he comes unto a hedge, wall, or strait, beyond which he cannot pass, and then in his own defence, and for safeguard of his own life kills the other: this is voluntary [i.e. intentional], and yet no felony, and the jury that find, it was done se defendendo, ought to find the special matter. ${ }^{693}$

If A assault B so fiercely and violently, and in such a place, and in such a manner, as if B should give back, he should be in danger of his life, he may in this case defend himself; and if in that defence he kills A, it is se defendendo, because it is not done felleo animo: [with a wicked intention] for the rule is, when he does it in his own defence, upon any inevitable cause, quod quis ob tutelam corporis sui fecerit, jure id fecisse videtur. [what one does to protect his person or his right he is held to do lawfully]. ${ }^{694}$

As for man's defence of his possessions and lands, Coke noted:

he may justify an assault and battery; but he cannot justify either mayheming, or wounding, [of a man's] life and member: and so note a diversity between the defence of his person, and the defence of his possessions and goods. ${ }^{695}$

In conclusion, there was nothing novel in Coke's analysis of murder and manslaughter (which analysis mainly derived from Bracton and Lambard) - including the proposition that an unlawful act, even if accidental, could be murder, since others prior to him had asserted the same. However, Coke's definition of murder became a classic since it neatly summarised the position.

\section{Summary - Law up to 1641}

If one considers the law on homicide from 1551 (see 21) up to the time when Coke's summary of it was published in 1641, there had been some changes. Also, it is useful to highlight the problems arising from the unnecessary use of legal fictions and inadequate categorisation:

- $\quad$ Murder. As in 1551, if the intentional killing was premeditated, so in 1641, it was called 'murder'. This crime remained unclergyable (sanctuary was abolished in 1628). There was forfeiture of land and goods. Further, a pardon was very unlikely and, so, the death penalty applied.

Problems.

- Inadequacy of Pre-requisite of Premeditation. The law still drew a distinction between premeditated killing (murder) and when a man killed in the heat of passion ('hot blood') - such as in a brawl. However, this formulation was unsatisfactory since such killing was also (often) intentional, albeit, on the spur of the moment and provoked. Thus, all intentional killing should have been murder, with it being reduced to manslaughter, if provoked or in self defence.

- Implied Malice. Although there may have been no premeditation (express malice), malice was implied (and so, treated as murder) in the case of:

(a) unprovoked killing;

(b) killing a police officer in the execution of his duty;

\footnotetext{
${ }^{688}$ Ibid. Coke, n 44, vol 2, p 316 also noted that 'If a man be indicted for killing of a man by misadventure [accident], or se defendendo, and is outlawed thereupon, he shall forfeit no lands, but goods and chattels only.'

${ }^{689}$ Coke, n 44, vol 3, p 55 'if a thief offer to rob or murder B, either abroad, or in his house, and thereupon assault him, and B defend himself without any giving back, and in his defence kills the thief, this is no felony; for a man shall never give way to a thief, etc neither shall he forfeit anything. And so it is declared by the statute of $24 \mathrm{H} 8$ [ i.e. Act of 1532, see 20(d)].' Coke also referred to cases in 1352, see ns 443 \& 450 , as well as to Semayne (1604), see App E(c).

${ }^{690}$ Ibid 'Likewise if a prisoner assault the gaoler, the gaoler is not by law inforced to give back; but in defence of himself he kill the prisoner, this is no felony.' Coke referred to a case in 1348 , see $\mathrm{n} 441$.

${ }^{691} \mathrm{Ibid}$ 'So if any officer, or minister of justice, that has lawful warrant, and the party assault the officer or minister of justice, he is not bound by law to give back, but to carry him away: and if in execution of his office he cannot otherwise avoid it, but in striving to kill him, it is no felony.'

${ }^{692}$ Ibid 'If at a joust or tournament, or at the play with sword and buckler by the king's commandment, one does kill another, this is no felony.' Coke cited a case in 1496, see $n$ 471. Coke continued 'In the reign of king H 2 [1154-89] it was enacted, that if in such case one was slain, it should be no felony, for that in friendly manner they contended to try their strength, and to be to do the king service in that kind, as occasion should be offered.' Coke cited The Mirror of Justices, n 25, p 31-2. For the position on lawful (licensed) tournaments, see McBain, n 215, especially n 993 (re The Mirror of Justices) and App G thereto.

${ }^{693}$ Coke, n 44, p 55. He cited a case in 1369, see $\mathrm{n} 452$.

${ }^{694}$ Ibid. The quotation is from Bracton, $\mathrm{n} 22$, vol 3, p 21 'quod quis ob tutelam sui corporis fecerit vel su juris juste fecisse videtur.'

${ }^{695}$ Coke, n 44, vol 2, p 315. Cited by Holdsworth, n 65, vol 3, p 279.
} 
(c) killing arising from an unlawful act;

(d) killing by a thief (robber);

(e) transferred malice;

(f) killing by neglect/cruelty (including duress by a jailer);

(g) killing by poison (save by Coke but cf. Act of 1547)

- Inadequacy of Unlawful. Following Bracton, if a person was killed in the course of an unlawful act, this prevented it being treated as wholly accidental. Bracton did not specify what were the consequences if the unlawful act was: (a) intentional; (b) negligent; (c) accidental. However, by Herbert (1588), it was being held that an unlawful act (an affray or, according to Brooke CJ, even a battery), if intentional, could be murder if death resulted. And Coke asserted that an unlawful act, even if accidental, could be murder. The result was draconian. Firing at a wild bird was lawful and, if a person missed and killed another, it was accidental. However, firing at a tame fowl (to steal the property of another) was unlawful and, if a person missed and killed another, it was murder. In fact, there was no need to have a pre-requisite of 'lawfulness' since the legal issues for both acts (i.e. of stealing and of killing) were separate. Further, it is possible, in any case, that Bracton never sought to elevate accidental, but unlawful, acts to the status of murder. Bracton's problem was that he had 'borrowed' from ecclesiastical law which law (following the Old Testament) regarded all killing as a grave sin (and only regarded even judicial killing as permitted on the basis that that the victim had brought the same upon himself).

- Manslaughter. By 1641, it was manslaughter when: (a) the killing was intentional, but there was sufficient provocation or it was excusable (i.e. self defence); or (b) the killing was pursuant to an lawful act, where the same was negligent (if wholly accidental it was treated as accidental killing). The same position as in 1551. Manslaughter was a felony. However, up to 1827 , benefit of clergy was available. And, there was a greater chance of securing a pardon. Thus, there was a difference between manslaughter and murder. Further, it is likely benefit of clergy was widely exercised.

Problems. Manslaughter should have only comprised: (a) where the charge of murder was reduced as a result of provocation; and (b) negligent killing (assuming that reckless killing was not conceived at that time). Also, the issue of the unlawfulness of the act should not have been taken into account.

- Accidental Killing. As in 1551, accidental killing, in 1641, was still treated as homicide. That is, a criminal act. However, a pardon was granted as a matter of course.

Problems. The requirement of a pardon was unnecessary. Also, the failure to separate negligent, from accidental, killing did not help the development of the ambits of manslaughter.

- Justifiable Killing. This had not changed since 1551. Thus, it remained justifiable (at common law) in 1641 to kill: (a) pursuant to due legal process; (b) a felon who resisted capture; (c) a burglar; ${ }^{696}$ (d) a housebreaker; (e) an enemy in war time; (f) an escaping prisoner; (g) a thief assaulting a person; (h) in a licensed martial game (though this would be treated as an accident). Further, Acts of Parliament also made it justifiable to kill where: (i) the Act of 1293 applied (warrens etc); (ii) the Act of 1532 applied (attempting to murder, rob or burgle); (iii) the Act of 1553 applied (unlawful assemblies).

Problems. The content of the Act of 1532 (see 20(d)), in particular, was also covered at common law, with the latter being wider (for example, it covered burglary during the day). This created uncertainty. Further, legal writers (mainly from Pulton) started to mix justifiable homicide (no crime) with excusable homicide (a crime, but a pardon granted as a matter of course). This also created legal uncertainty.

- Excusable Killing. In Bracton's time (c.1240), it was a defence to kill a person: (a) in self defence; (b) to defend one's family (and servants); (c) to defend one's master (lord). This still applied in 1551 and in 1641.

Problems. The requirement of a pardon in the case of excusable killing was unnecessary, leading to delay and administration. Further, both Pulton and Coke tended to confuse justifiable and excusable killing. The 'back to the wall' principle was a construction of law that was unnecessary since this issue should have been a question of fact as to whether the conduct of the killer was reasonable self defence in the circumstances.

\section{Hale (c. 1670)}

Hale - in his History of the Pleas of the Crown (published in 1736, but reflecting the law in the 1670's) - discussed the law of homicide and his text was often cited thereafter - mainly for the examples which it provided. ${ }^{697}$ Hale also referred to homicide, in much shorter fashion, in his Pleas of the Crown (1685).

\section{(a) Murder}

Hale stated:

Murder and manslaughter differ not in the kind or nature of the offence, but only in the degree, the former being the killing of a man of malice prepense, the latter upon a sudden provocation and falling out. ${ }^{68}$

\footnotetext{
${ }^{696}$ The distinction, at common law, between a burglar at night and one during the day seems to have gone. The Act of 1532 , however, referred only to the night, see 20(d).

${ }^{697}$ It may be noted that Hale analysed the Old Testament position, something no prior texts on criminal law had done in any detail. See Hale, $\mathrm{n} 45$, vol 1 , Proemium. For criticism of the structure of Hale's analysis ('heaviness, obscurity, and superabundant detail') see Stephen, n 55, vol 3, pp 60-1. One would agree. However, it is to remembered that this text is posthumous.

${ }^{698}$ Hale, $\mathrm{n} 45$, vol 1, p 449. He continued 'And therefore it is, that upon an indictment of murder the party offending may be acquitted of murder, and yet found guilty of manslaughter...' Hale also noted that an indictment for murder required the words 'felonice ex malitia sua praecogitata interfecit et
} 
Hale noted that premeditated malice could be: (i) express; or (ii) implied. ${ }^{699}$

- $\quad$ Express Malice. Hale defined express malice (also, called malice in fact) as: 'a deliberate intention of doing any bodily harm to another, whereunto by law he is not authorised [i.e. where it was unlawful] '; 700

- Malice in Law. He noted that malice in law (also, called malice in law or malice by presumption of law) was presumed in certain types of killing. ${ }^{701}$

\section{(i) Express Malice}

Hale gave various examples of express malice. The crucial issue in these was the degree of provocation ('hot blood') which would reduce murder to manslaughter.

- $\quad$ Law Suit. A long lawsuit between A and B 'either touching interest or wrong done' (as if A sued B or threaten to sue him) was insufficient evidence of malice prepense if they met, fell out, fought and one killed the other where that fight happened on a sudden provocation [i.e. hot blood] $;^{702}$

- Old Quarrel. An old quarrel between A and B. They were reconciled. On a new (and sudden) falling out, A killed $\mathrm{B}$ [i.e. hot blood]. This was not murder. However, if - in the circumstances - it appeared the reconciliation was 'but pretended or counterfeit' and the killing was 'on the score of the old malice', it was murder; [i.e. premeditated malice]

- $\quad$ Prior Malice. There is malice between A and B. They met. On account of that malice, A struck B who killed A (otherwise than in his own defence). It was murder in B [i.e. premeditated malice]; ${ }^{703}$

- Duel. A challenged $\mathrm{C}$ to fight. $\mathrm{C}$ declined but was threatened by A to be 'posted for a coward', if not. Thus, A and $\mathrm{B}$ (his second) and $\mathrm{C}$ and $\mathrm{D}$ (his second) met. $\mathrm{C}$ killed $\mathrm{A}$. This was murder in $\mathrm{C}$ and $\mathrm{D}$ - even though $\mathrm{C}$ unwillingly accepted the challenge [i.e. because they had agreed to duel. Thus, premeditated malice]; ${ }^{704}$

- Challenge. A challenged B to fight. B declined but let A know he would not be beaten and would defend himself. $\mathrm{B}$, going about wearing a sword, was later assaulted and killed by A. This was murder in $\mathrm{A}$ [i.e. a duel and, thus, premeditated malice, because B let A know he would not be beaten]. However, if B had killed A on that assault, it would have been in self defence if he could not escape otherwise, or bare homicide, if he could escape and did not: $^{705}$

- $\quad$ Falling Out. A and B suddenly fall out. They agree to fight and run and fetch their weapons. They fight. A kills B. This is not murder 'for it is but the continuance of the sudden falling out, and the blood was never cooled.' However, 'if there were such a competent distance of time that, in common presumption, they had time of deliberation' it was murder; 706

- $\quad$ Revenge. A (son of B) and C (son of D) fall out and fight. A is beaten and runs home to this father, all bloody. B takes a staff and goes to $\mathrm{C}$ (three quarters of a mile distant) and strikes him. C dies. This was not murder in $\mathrm{B}$ because it was done in 'sudden heat and passion. '; ${ }^{707}$ [i.e. hot blood]

- Excessive Correction. A boy was in a park to steal wood. The park-keeper coming, he hid in a tree. The park keeper bid him come down. On so doing, the keeper struck him twice and then bound him to a horse's tail, which horse dragged him until the boy's shoulder was broken and he died. It was held murder, because the correction was excessive and it was an act of deliberate cruelty. ${ }^{708}$

These cases indicate the difficulties the courts had in respect of provocation when bound by the rigid idea that murder could

murdravit' (he killed and murdered him feloniously with malice aforethought) whereas that for manslaughter was only 'felonice interfecit' (he killed him feloniously). Ibid, p 450. Also, Ibid, p 425 'Murder is a killing of a man ex militia praecogitata; homicide is killing a man without forethought malice.' See also Hale PC, n 45, p 43 'Murder is when a person kills another of malice within any county in England, so he die within a year and a day.'

${ }^{699}$ Ibid, p 450.

${ }^{700}$ Ibid, p 451. Also, 'Malice in fact is a deliberate intention of doing some corporal harm to the person of another.' Also, 'The evidences of such a malice must arise from external circumstances discovering that inward intention, as lying in wait, menacings antecedent, former grudges, deliberate compassings, and the like, which are various according to a variety of circumstances. It must be a compassing or designing to do some bodily harm.' See also Hale PC, n 45, p 44 et seq.

${ }^{701}$ Ibid 'Malice in law, or presumed malice, is of several kinds, viz. (1) in respect of the manner of the homicide, when without provocation. (2) In respect of the person killed, viz. a minister of justice in execution of his office. (3) In respect of the person killing.' See also Hale PC, $\mathrm{n} 45$, p 44 et seq.

${ }^{702}$ Ibid, p 451. Hale continued, pp 452-3 'but this may by circumstances be heightened into a malice prepense, as if A without any new provocation strikes B upon the account of that difference in law, whereof B dies, or e converso, or if he lie in wait to kill him, or come with a resolution to strike or kill him, for in such a case the difference in the law suit (which alone makes not malice) is coupled and joined with circumstances, that prove the purpose of the party was more, than the law allows in a legal vindication of wrong done.'

${ }^{703}$ Ibid. Hale continued, p 452 'but if they meet accidentally, and A assaults B first, and B merely in his own defence, without any other malicious design kills A this is not murder in B for it was not upon the account of the former malice, but upon a new and sudden emergency for the safeguard of his life.' [i.e. self defence] However, 'if A and B had met deliberately to fight, [i.e. a duel] and A strikes B and pursues B so closely, that B in safeguard of his own life kills A this is murder in B because their meeting was a compact, and an act of deliberation, and therefore all, that follows thereupon, is presumed to be done in pursuance thereof.' (italics supplied)

${ }^{704}$ Hale cited Taverner (1616), see App B(a). Hale stated, n 45, vol 1, p 453 'But it seems not to be murder in B because although he had malice against $\mathrm{C}$ and D his opponents, yet he had none against A though some have thought it to be murder also in B because done by compact and agreement.'

${ }^{705}$ Ibid, p 453. Hale continues 'But if B had only made this as a disguise to secure himself from the danger of the law, and purposely went to the place, where probably he might meet A and there they fight, and he kills A then it had been murder in B but herein circumstances of the fact must guide the jury.'

${ }^{706}$ Ibid. Hale cited Morgan (1610), see App B(a). Also, Coke, n 44, vol 3, p 51, see 26.

${ }^{707}$ Ibid, p 453. Hale cited Rawly (1612) see App B(g).

${ }^{708}$ Hale cited Holloway (1628), see App B(g). 
only occur if there was premeditation. Further, the case of excessive correction (see above) is one where there was (usually) no express premeditated malice. That is, no intention to kill. However, really, as a matter of 'public policy', it was adjudged murder.

\section{(ii) Implied Malice}

Hale distinguished between killing: (a) voluntarily (intentionally) committed without provocation; (b) of a minister of justice; and (c) by a person who intended to steal or burgle. ${ }^{709}$ Hale stated:

When one voluntarily [intentionally] kills another without any provocation, it is murder, for the law presumes it to be malicious, and that he is hostis humani generis [an enemy of the human race]; it remains therefore to be inquired, what is such a provocation, as will take off the presumption of malice in him, that kills another. ${ }^{710}$

This proposition is important since murder now comprised intentional killing, absent provocation. Further, there was a presumption that it was murder, unless provocation was shown. This was not a change in the law (Coke had said as much), however, Hale put it even more pithily. Given this, it is a pity that murder was not now defined to exclude reference to 'premeditated malice'. Hale also referred to the need for the provocation to be sufficient to reduce intentional killing to manslaughter. He cited the following examples of murder, because there was no (or insufficient) provocation:

- $\quad$ Poison. A intentionally gave poison to another. It was murder 'because it is an act of deliberation odious in law, and presumes malice, $;^{711}$

- $\quad$ Debt. A demanded a debt of B who killed him. It was murder 'because it is no provocation'; 712

- $\quad$ Slight Provocation. W, in the shop of B, distorted his mouth and smiled at him. B killed W. It was murder 'for it was no such provocation, as would abate the presumption of malice in the party killing'. 713 In this case the lack of substantive provocation was emphasized;

- $\quad$ Taking the Wall. A and B met. There was a convenient distance between A and the wall. B took the wall of A, who killed him. It was murder. However, 'if B had jostled A this jostling had been a provocation and would have made it manslaughter.' [i.e. hot blood]. So too, if A riding on the road, B had whipped the horse of A out of the track and A had then alighted and killed B. [i.e. hot blood]. It was manslaughter; ${ }^{714}$

- $\quad$ Slighting Words. A gave slighting words to B who immediately killed him. It was murder. ${ }^{715}$ Thus, the courts held that words alone did not comprise sufficient provocation;

- Husband and Wife. A wife chided her husband. He struck her with a pestle, killing her. It was held murder, since the 'chiding' was insufficient to extenuate it to manslaughter. ${ }^{716}$

These cases indicate the problems of dividing malice into 'express' and 'implied' - not least since poisoning a person was regarded as premeditated from very early times. Hale then considered the second kind of malice:

when a minister of justice, as a bailiff, constable, or watchman etc is killed in the execution of his office, in such a case it is murder. ${ }^{717}$

As in the case of express and implied malice generally, subtle distinctions were made in the caselaw to deal with this scenario. ${ }^{718}$ Finally, as to the third kind of malice, Hale provided the following instances, viz.

- $\quad$ Robbery. A came to rob B in his house (or on a highway) or otherwise without prior intent to kill him. If in the attempt - either with, or without, the resistance of B - he killed B, it was murder; ${ }^{719}$

- $\quad$ Theft from Park. A man came to steal animals in a park, forest or warren. The parker (forester or warrener) resisted and was killed. It was murder; ${ }^{720}$

- Gaol. A prisoner died by reason of duress by the gaoler. It was murder. ${ }^{721}$ Coke had also treated this as implied malice;

- $\quad$ Transferred Malice. If A struck B and, missing him, hit $\mathrm{C}$ who died, it was murder. ${ }^{722}$

Elsewhere, Hale referred to murder by virtue of an unlawful act, stating:

What unlawful act, whereupon death ensuing will make manslaughter? If the unlawful act be deliberate, and tend to

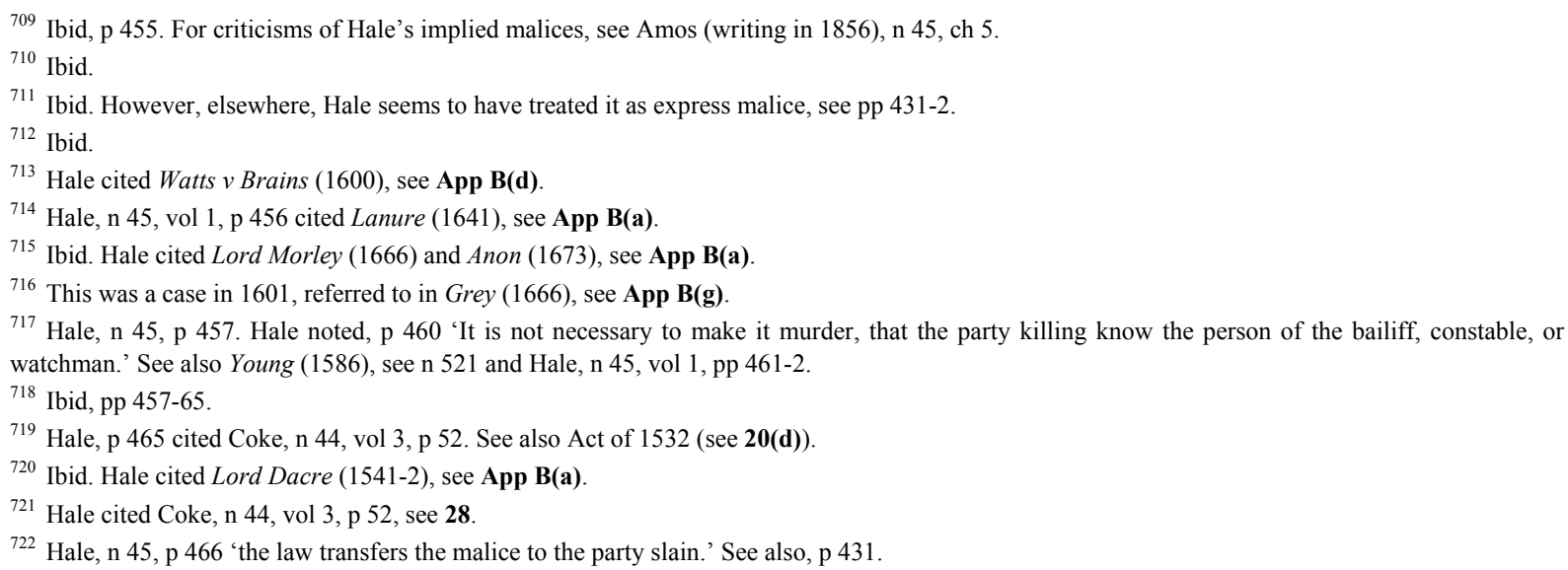


the personal hurt of any immediately, or by way of necessary consequence, death ensuing, [it] is murder. ${ }^{723}$ For Hale (unlike Coke) intentional, unlawful, killing was murder. If negligent or accidental, it was manslaughter.

Thus, Hale cited 7 cases of implied malice: (a) unprovoked killing; (b) killing a police officer in the execution of his duty; (c) killing arising from an unlawful act; (d) killing by a thief (robber); (e) transferred malice; (f) killing by neglect (duress of a gaoler); (g) killing by poison. Like Coke, Hale regarded (it seems) other cases of killing by neglect/cruelty, as express malice.

\section{(b) Manslaughter (Simple Homicide)}

Hale stated:

Manslaughter or simple homicide, is the voluntary [intentional] killing of another without malice express or implied..., 724

The categories Hale treated as manslaughter were killings as a result of: (a) a brawl (sudden falling out); ${ }^{725}$ (b) sudden provocation; ${ }^{726}$ and (c) an unlawful act. ${ }^{727}$ In the case of the unlawful killing, Hale was one of the first to more clearly distinguish negligent from accidental conduct. He cited the instance of a killing arising from the driving of a cart:

A drives his cart carelessly, and it runs over a child in the street, if A have seen the child, and yet drives on upon him, it is murder; but if he saw not the child, yet it is manslaughter; but if the child had run cross the way, [and assuming the carter was not otherwise careless] and the cart run over the child before it was possible for the carter to make a stop, it is per infortunium, and accordingly this correction was given by us at Newgate sessions in 1672 and the carter convict of manslaughter. ${ }^{728}$

Hale also gave other instances:

a man knowing that people are passing along the street throws a stone, or shoots an arrow over the house or wall with intent to do hurt to people, and one is thereby slain, this is murder, and if it were without such intent, yet it is manslaughter, and not barely per infortunium, because the act itself was unlawful;

but if a man were tiling an house, and let fall a tile knowingly, and gave warning, and yet a child is killed, this is per infortunium, but if he gave not convenient warning, it is manslaughter, quia non adhibuit debitam diligentiam.' [because he did not show due care, following Bracton, see n 352]...

If $\mathrm{A}$ in his own park shoot at a deer, and the arrow glancing against a tree hits and kills $\mathrm{B}$ this is homicide per infortunium, because it was lawful for him to shoot in his own park. But if A without the licence of B hunt in the park of B and his arrow glancing from a tree kills a by-stander, to whom he intended no hurt, this is manslaughter, because the act was unlawful.

So if A throw a stone at a bird, and the stone strikes and kills another, to whom he intends no harm, it is per infortunium. But if he had thrown a stone to kill the poultry or cattle of B and the stone hit and kill a bystander, it is manslaughter, because the act was unlawful, but not murder, because he did not do it maliciously, or with an intent to hurt the bystander. ${ }^{729}$

Therefore, if unlawful and intentional, to Hale it was murder. If unlawful and negligent or accidental it was manslaughter .

\section{(c) Accidental Killing - Lawful Act}

Hale distinguished manslaughter (simple homicide) which was intentional ('voluntary'), from accidental killing or killing in self defence, which were unintentional ('involuntary'). As to the latter, he stated:

Involuntary homicide is the death or hurt of the person of a man against or besides the will of him that kills him... This involuntary homicide is of two kinds. viz. either 1 . When it is purely involuntary and casual, as the killing of a man per infortunium [by accident] or 2. When it is partly involuntary, and partly voluntary, but occasioned by a necessity, that the law allows, which is commonly called homicide ex necessitate as killing a man in his own defence [see (d) below]...730

In respect of accidental killing, Hale stated:

Homicide per infortunium is, where a man is doing a lawful act, and without intention of bodily harm to any person, and by that act death of another ensues... ${ }^{731}$

\footnotetext{
723 Ibid.

${ }^{724}$ Ibid, p 466. See also Hale PC, p 56 'Killing another upon a sudden falling out, or provocation, or unjustifiable [unlawful] act, manslaughter.'

${ }^{725}$ Ibid. See also Hale PC, n 45, p 56 'What a sudden falling out? Two combat and part, and presently come together and fight, or one presently fetches a weapon and kills the other, or they presently fetch their weapons, and go into the field, and one kills the other, manslaughter.'

${ }^{726}$ Ibid. See also Hale PC, p 57 'What a sudden provocation? Two strive for the wall, and one kills the other, manslaughter.'

727 Ibid.

${ }^{728}$ Ibid, p 476. Also, 'If a man or boy riding in the street whip his horse to put him into speed, and run over a child and kill him, this is homicide, and not per infortunium, and if he rid [rode] so in a press of people with intent to do hurt, and the horse had killed another, it had been murder in the rider. But if a man or boy be riding in the street, and a bystander whip the horse, whereby he runs away against the will of the rider, and in his course runs over and kills a child or man, it is chance medley only.'

${ }^{729}$ It is likely Hale had regard to Roman law, see Digest, n 182, 9.2 (Lex Aquila) and 3 (Those who Pour or Throw things out of Buildings). See also Baker, n 459, pp 310-2

${ }^{730}$ Hale, n 45, vol 1, p 471 .

${ }^{731}$ Ibid, p 472. Ibid, p 477 'Tho the killing of another per infortunium be not in truth felony, nor subjects the party to a capital punishment...yet the party forfeits his goods, and tho he ought to have... a pardon of course upon the certificate of the conviction, yet he is not to be discharged out of prison, but
} 
Hale cited examples of accidental killing: (a) a man shooting at a target, his arrow unintentionally kills a bystander; and (b) a carpenter (or a mason) in a building lets fall a piece of timber or stone, killing another. ${ }^{732}$ Also:

- $\quad$ playing games; $;^{733}$

- $\quad$ correcting a student; ${ }^{734}$

- $\quad$ entering a house as a trespasser (as opposed to entering to commit a felony); ${ }^{735}$

- throwing stones or shooting arrows. ${ }^{736}$

It is a pity that Hale did not develop a separate category of negligence which treated manslaughter as covering both lawful and unlawful acts since this would be have been apposite (since he did not treat unlawful but negligent acts as murder).

\section{(d) Justifiable Killing}

Hale cited as an example, killing pursuant to due legal process ${ }^{737}$ and an alien enemy (in the heat of war). ${ }^{738}$ However, he did not cite any other instances which had in the past been treated as such. Instead, as shown below, he treated examples of justifiable homicide as excusable homicide. However, one would suggest that this mistake arose from the editing of Hale's text long after his death (his History was not published until 1736, yet he died in 1676). Further, Hale's Pleas of the Crown (published in 1685) correctly cites such instances as examples of justifiable, and not excusable, homicide. This is dealt with in (e).

\section{(e) Excusable Killing}

Hale discussed 'necessary' killing. He distinguished those: (a) of a private nature; and; (b) where justice required it. ${ }^{739}$ As to the categories of excusable killing, these were:

- $\quad$ Self defence. ${ }^{740}$ Hale noted that - generally - it was only available when the person defending could no longer flee ${ }^{41}$ (the flight must be real) ${ }^{742}$ or flight was otherwise impossible. ${ }^{743}$ Self defence also applied to an officer of the law and a gaoler, who did not have to prove the need for 'back to the wall'; ${ }^{744}$

- Defending Others. This included a servant defending his master (and vice versa) and a person defending his family. ${ }^{75}$ A stranger could also be defended; ${ }^{746}$

bailed to the next term or sessions to sue out his pardon of course, for tho it was not his crime, but his misfortune, because the king has lost his subject, and that men may be the more careful, he forfeit his goods, and is not presently absolutely discharged of his imprisonment, but bailed.'

732 (a) as if a man be shooting at buts or pricks, and by casualty his hand shakes and the arrow kills a bystander; (b) if a carpenter or mason in building casually let fall a piece of timber or stone, and kills another [it is an accident]... But if he voluntarily let it fall, whereby it kills another, if he give not due warning to those that are under, it will be at least manslaughter; quia debitam diligentiam non adhibuit [because he did not show due care - see Bracton, $\mathrm{n}$ 352]; (c) if a man be felling a tree in his own ground, and it fall and kill a person, it is chance medley.' Hale cited the Case of Thorns (1466), see $\mathrm{n} 495$ and noted that a civil remedy (trespass) would lie in respect of such acts.

${ }^{733}$ Ibid, p 472-3. 'He that voluntarily and knowingly intends hurt to the person of a man, though he intend not death, yet if death ensues, it excuses not from the guilt of murder, or manslaughter at least, as if A intends to beat B but not to kill him, yet of death ensues, this is not per infortunium, but murder or manslaughter, as the circumstances of the case happen. And therefore I have known it ruled, that if two men are playing at cudgels together, or wrestling by consent, if one with a blow or fall kill the other, it is manslaughter, and not per infortunium... if two play at barriers, or run a tilt without the king's commandment, and one kill the other, it is manslaughter; but if it be by the king's command, it is not felony, or at most per infortunium [accident].' Hale cited Sir John Chichester (1670), see App F(a).

${ }^{734}$ Ibid, pp 473-4 'if a schoolmaster correct his scholar, or a master his servant, or a parent his child, and by struggling, or otherwise, the child or scholar, or servant die, this is only per infortunium... But this is to be understood, when it happens only upon moderate correction, for if the correction be with an unfit instrument, or too outrageous, then it is murder.' Hale cited Anon (1670), see App B(g).

${ }^{735}$ Ibid. 'Several persons come to enter the house of A as trespassers, A shoots and kills one, this is manslaughter, otherwise it had been, if they had entered to commit a felony...' Hale cited Harecourt (1562), see App E(c). See also Hale PC, n 45, p 40 where Hale indicated it was manslaughter 'if one come to enter into my house, claiming title, and I kill him.' Also, 'If A enter wrongfully into the house of B riotously and forceably, B and others endeavour to fire the house, A kills, manslaughter.'

${ }^{736}$ See (b).

${ }^{737}$ Hale, n 45, pp 496-502. See also Hale PC, n 45, p 35.

${ }^{738}$ Ibid, vol 1, p 433 'If a man kill an alien enemy, within this kingdom, yet it is felony, unless it be in the heat of war, and in the actual exercise thereof.'

${ }^{739}$ Ibid, p 478. As to (a): 'The former is that necessity, which obliges a man to his own defence and safeguard...' Hale considered, in this context: (a) self defence; (b) defending another; (c) defending his goods; (d) defending his house.

${ }^{740}$ Ibid, p 479 'Homicide se defendendo is the killing of another person in the necessary defence of himself against him, that assaults him.'

${ }^{741}$ Ibid, p 481 'Regularly, it is necessary, that the person, that kills another in his own defence, fly as far as he may to avoid the violence of the assault before he turn upon his assailant...' Also, p 482 'If A assault B so fiercely, that B cannot save his life if he give back, or if in the assault B fall to the ground, whereby he cannot fly, in such case if B kills A it is se defendendo.'

${ }^{742}$ Ibid, p 483 'the flight to gain the advantage of se defendendo to the party killing must not be a feigned flight, or a flight to gain advantage of breath, or opportunity to fall on afresh... but it must be a flight from the danger, as far as the party can, either by reason of some wall, ditch, company, or as the fierceness of the assailant will permit.' Hale cited a case in 1671, see App D(a). See also Stephen, n 55, vol 3, p 65.

${ }^{743}$ Ibid, p 482. 'The party assaulted indeed shall by the favourable interpretation of the law have the advantage of this necessity to be interpreted as a flight to give him the advantage of se defendendo, when the necessity put upon him by the assailant makes his flight impossible...'

${ }^{744}$ Ibid, p 481 'If the gaoler be assaulted by his prisoner, or if the sheriff or his minister be assaulted in the execution of his office....if he kill the assailant, it is in law adjudged se defendendo... the like of a constable or watchman, for they are ministers of justice...' Hale referred to Mackalley (1611), see App B(c). Cf. 'But if the prisoner makes no resistance, but flies, yet the officer, either for fear, that he or some other party will rescue the prisoner, strikes the prisoner, where of he dies, this is murder, for here was no assault first made by the prisoner, and so it cannot be se defendendo in the officer.' 
- Defending one's Home. It was excusable to kill when there was an attack on a person's home (it being treated the same as self defence). ${ }^{74}$ However, this did not apply when there was mere trespass.

The examples of self defence and defending one's family had long established precedent (a welcome advance was the inclusion of strangers). Hale then treated the following as excusable homicide, when they actually comprised examples of justifiable homicide. Thus, killing was held to be defensible (actually justifiable) in the following instances:

- $\quad$ to prevent a felony ${ }^{748}$ - including robbery, ${ }^{749}$ murder ${ }^{750}$ and rape; ${ }^{751}$

- $\quad$ a felon (if indicted or committed but not if only suspected) resisting arrest; ${ }^{752}$

- a person escaping, when being taken to prison; ${ }^{753}$

- a person escaping from prison. ${ }^{754}$

Also, where the following statutes applied, the:

- Act of 1293 (on warrens, see 17); 755

- Act of 1532 (attempting to murder, rob, burgle, see 20(d)); ${ }^{756}$

- Act of 1553 (unlawful assemblies, see 22). ${ }^{757}$

However, Hale noted that it was not excusable homicide to kill an adulterer in flagrante. ${ }^{758}$

In conclusion, the writing of Hale closely followed Coke in respect of the categories of implied malice, save that he restricted murder to unlawful intentional acts - unlike Coke who would have included negligent and accidental ones as well.

\section{Hawkins (1716-21)}

In the first edition of his Treatise on the Pleas of the Crown in 1716-21(a publication that was to continue until 1824)

\footnotetext{
${ }^{745}$ Ibid, p 484 'The like law had been for a master killing in the necessary defence of his servant, the husband in the defence of the wife, the wife of the husband, the child of the parent, or the parent of the child, for the act of the assistant shall have the same construction in such cases, as the act of the party assisted should have had, if it had been done by himself, for they are in a mutual relation one to another.'

${ }^{746}$ Ibid. 'if B and $\mathrm{C}$ be at strife, A a bystander is to use all lawful means, that he may without hazard of himself, to part them, and the very relation of acquaintance, and mutual society between A, B and C seems to excuse the fact of A in the necessary safeguard of the life of B from the crime of simple homicide.'

${ }^{747}$ Ibid. p 485 'if A kill him in defence of his house, it is neither justifiable, nor within the privilege of se defendendo for he entered only as a trespasser, and therefore it is at least common manslaughter.' He cited Harecourt (1562), see App E(c).'

748 Ibid, p 481 'if a felon fly, and he cannot be otherwise taken, if he be killed, it is no felony, and in that case the officer so killing forfeits nothing... Also, p 484 'the reason seems to be, because every man is bound to use all possible lawful means to prevent a felony, as well as to take the felon, and if he does not he is liable to a fine and imprisonment.'

749 Ibid, p 484 'If A be travelling, and B comes to rob him, if C falls into the company, he may kill B in defence of A and therefore much more, if he comes to kill him, and such his intent be apparent, for in such case of a felony attempted, as well as of a felony committed, every man is thus far an officer; that at least his killing of an attempter in the case of necessity puts him in the condition of se defendendo in defending his neighbour.' Cf. Hale PC, $\mathrm{n} 45$, p 39 'If thieves assault me in the highway, or in my house to rob me, and I, or my servant kill them, no felony or forfeiture...' [citing the1532 Act] (italics supplied)

${ }^{750}$ See $\mathrm{n} 749$. Also, Ibid, p 481 'If a thief assault a true man either abroad or in his house to rob or kill him, the true man is not bound to give back but may kill the assailant, and it is not felony'. Hale cited Coke, n 44, vol 3, p 56. Cf. p 487 'At common law, if a thief had assaulted a man to rob him; and he had killed the thief in the assault, it had been se defendendo...' See also the Act of 1532 (see 20(d)).

${ }^{751}$ Ibid, p 485 'A makes an assault upon B a woman or maid with intent to ravish her, she kills him in the attempt, it is se defendendo, because he intended to commit a felony...so it is if the husband or father of B had killed him in the attempt, if it could not be otherwise prevented, but if it might be otherwise prevented, it is manslaughter...' Cf. Hale PC, n 45, p 39 'If a woman kill him that assaults to ravish her, no felony.' See also a case in 1352 , see n 451 .

752 Ibid, p 489 'If a person be indicted of felony and flies, or being arrested by warrant or process of law upon such indictment escapes and flies, and will not render himself, whereupon the officer or minister cannot take him without killing of him, this is not felony... But if he may be taken without severity, it is at least manslaughter in him, that kills him, therefore the jury is to inquire, whether it were done of necessity or not...' Also 'the same law it is, if A commits felony and flies, or resists the people, that come to apprehend him, such killing is not felony...for in such case the law makes every person an officer to apprehend a felon.' (italics supplied). It was not justifiable to kill if a person was suspected of felony. Ibid, $\mathrm{p} 490$.

${ }^{753}$ Ibid, pp 489-90 'if he be taken, and in bringing to the gaol he breaks away, and the people of the vill pursue and cannot take him, unless they kill him, those, that kill him, upon their arraignment shall be acquitted of the felony...'.

${ }^{754}$ Hale PC, n 45, p 37 'If a prisoner assaults his gaoler, and he kills the prisoner, no felony.' See also case in 1348 , see $\mathrm{n} 429$.

${ }^{755}$ Hale, n 45, vol 1, p 491. Also, Hale PC, n 45,p 37 '[A] keeper or parker may kill hunters, if they fly or defend themselves.' For a curious case of Sir William Hawkesworth who, weary of life, in 1471, had his park keeper shoot him, see Hale, n 45, vol 1, p 40 and East, n 50, vol 1, p 275.

${ }^{756}$ Ibid, p 487 'if A had attempted a burglary upon the house of B to the intent to steal, or to kill him, or had attempted to burn the house of B or if B or any of his servants, or any within his house had shot and killed A this had not been so much as felony...for his house is his castle of defence.' Ibid, $\mathrm{p} 488$ 'he, that attempts the wilful burning of a house, and is killed in that attempt, is free from forfeiture...'. Hale cited a case in 1352 , see $\mathrm{n} 450$ and Harecourt, see App E(c). See also Hale PC, n 45, p 39 'If a man come to burn my house and I shoot out of my house, or issue out of my house, and kill him, no felony.'

${ }^{757}$ Ibid. 'Rioters or forcible enterers or detainers, standing in opposition to the justice's lawful warrant, and one of them is slain, no felony.' This may also be a reference to the Case of Armes (1597), see $\mathrm{n} 545$.

${ }^{758}$ Ibid, p 486 'A commits adultery with B the wife of $\mathrm{C}$ who comes up and takes them in the very act, and with a staff kills the adulterer upon the place, this is manslaughter, and neither murder, nor under the privilege of se defendendo; but if A had been taken by $\mathrm{C}$ in the very attempt of rape and come and killed $\mathrm{A}$ in the act of his ravishment, it had been within the privilege of se defendendo, because it was a felony; the former case was adjudged manslaughter.' Hale referred to Manning (1670), see App D(d).
} 
Hawkins considered murder and manslaughter.

\section{(a) Murder}

Hawkins noted that the term 'murder' was first restricted to the murder fine (abolished in 1340) ${ }^{759}$ but that:

By murder therefore at this day we understand, the wilful [intentional] killing of any subject whatsoever, through malice forethought... ${ }^{760}$ (underlining supplied)

In respect of the manner of murder, Hawkins stated that:

not only he who by a wound or blow, or by poisoning, strangling or famishing etc directly causes another's death, but also in many cases, he who by wilfully and deliberately doing a thing which apparently endangers another's life, thereby occasions his death, shall be adjudged to kill him. ${ }^{761}$

As to the nature of malice aforethought, Hawkins stated:

any formed design of doing mischief may be called malice; and therefore that not such killing only as proceeds from premeditated hatred or revenge against the person killed, but also in many other cases, such as is accompanied with those circumstances that show the heart to be perversely wicked, is adjudged to be of malice prepense, and consequently murder. ${ }^{762}$

Hawkins then considered express ${ }^{763}$ and implied ${ }^{764}$ malice. In the case of malice, Hawkins considered, in particular:

- duelling and fighting in 'cool blood'; $;$ '

- where there was no provocation or it was only slight; ${ }^{766}$

- $\quad$ killing in revenge in cold blood or with cruelty; ${ }^{767}$

- transferred malice. $^{768}$

Hawkins then considered the situation where killing arose while a person was performing an unlawful act. ${ }^{769}$ He analysed this under (his own) categories, where the:

- $\quad$ principal intention was to commit another felony; 770

- principal intention was to commit a bare breach of the peace, not intended against the person slain; ${ }^{771}$

- $\quad$ chief motive was to assist a third person; ${ }^{772}$

- $\quad$ direct design was to escape from an arrest; ${ }^{773}$

\footnotetext{
${ }^{759}$ Hawkins, n 46, vol 1, p 78 'Murder, which anciently signified only the private [i.e. secret] killing of a man, for which by force of a law introduced by king Canutus for the preservation of his Danes, the town or hundred where the fact was done, was to be amerced to the king, unless they could prove that the person slain were an Englishman (which proof was called engleschire) nor could produce the offender etc.'

${ }^{760}$ Ibid. Also, p 80 'it is agreed, that the malicious killing of any person... is murder.' See also J Rastell, Les Termes de la Ley (1708) 'Murder is a willful killing of a man upon malice forethought, and seems to come of the Saxon word morden [morth] which it signifies.'

${ }^{761}$ Hawkins, n 46, vol 1, pp 78-9 cited examples of: (a) neglect, see case in 1328, see n 432. (b) abandoning a child (the same as neglect), see Anon (1599), see App B(e); (c) perjury (although it is doubtful this was a capital offence and Blackstone, see 32, was to hold otherwise).

${ }^{762}$ Ibid.

${ }^{763}$ Ibid 'Murder as is occasioned through an express purpose to do some personal injury to him who is slain in particular, which seems to be most properly called express malice.'

${ }^{764}$ Ibid. 'Such as happens in the execution of an unlawful action, principally intended for some other purpose, and not to do a personal injury to him in particular who is slain, in which case the malice seems to be most properly said to be implied.'

${ }^{765}$ Ibid, pp 80-1 'where ever two persons in cool blood meet and fight on a precedent quarrel, and one of them is killed, the other is guilty of murder...' Hawkins made it clear that a duel (killing in cold blood) was murder. Ibid, p 82.

${ }^{766} \mathrm{Ibid}, \mathrm{p} 82$ 'Such murder as happens in killing another without any provocation, or but upon a slight one, as to which it is to be observed, that where ever it appears that a man killed another, it shall be intended, prima facie, that he did it maliciously, unless he can make out the contrary, by showing him that he did it on a sudden provocation etc.' Hawkins then considered, inter alia, pp 82-3, (a) finding a man in bed with his wife; (b) killing another while contending for the wall; (c) defending oneself from unlawful arrest; (d) defending his house from those claiming a title to it; (e) defending his room in a public house (inn). For the latter, see Ford (1627-31), see App E(c).

${ }^{767}$ Ibid, p 83. In particular, Hale cited Mawgridge (1707) and Holloway (1628), see App B(g).

768 Ibid, pp 79 \& 84.

${ }^{769}$ Ibid. 'In what cases such killing shall be adjudged murder, which happens in the unlawful execution of an unlawful action, principally intended for some other purpose, and not to do a personal injury to him in particular who happens to be slain...'

${ }^{770}$ Ibid 'wherever a man happens to kill another in the execution of a deliberate purpose to commit any felony, he is guilty of murder; as where a person shooting at tame fowl, with an intent to steal them, accidentally kills a man; or where one sets upon a man to rob him, and kills him in making resistance, or where a person shooting at, or fighting with one man, with a design to murder him, misses and kills another.' [i.e. transferred malice]. In particular, Hawkins noted, $\mathrm{n} 46, \mathrm{p} 84$, that - if in a quarrel, a JP or policemen intervening was killed - it was murder. (italics supplied)

${ }^{771}$ Hawkins, n 46, vol 1, p 83 'where divers persons resolving generally to resist all opposers in the commission of any breach of the peace, and to execute it in such a manner as naturally tends to raise tumults and affrays, as by committing a violent disseisen with great numbers of people, hunting in a park etc and in so doing happen to kill a man, they are all guilty of murder, for they must at their peril abide the event of their actions, who wilfully engage in such bold disturbances of the public peace, in open opposition to, and defence of, the justice of the nation.'

${ }^{772}$ Ibid, p 85 'if a master maliciously intending to kill another take his servants with him, without acquainting them with this purpose, and meet his adversary and fight with him, and the servants seeing their master engaged take part with him, and kill the other, they are guilty of manslaughter only, but the master of murder.'

${ }^{773}$ Ibid, p 86 'whoever kills a sheriff, or any of his officers, in the lawful execution of civil process, as on arresting a person upon a capias etc is guilty of murder.'
} 
- $\quad$ principal purpose was to usurp an illegal authority; 774

- no mischief was intended at all (that is, it was an idle or wanton act). ${ }^{775}$

If one sorts through all this obscurity, it seems that Hawkins accepted Coke (and Hale's) seven categories of implied malice, save in respect of poisoning which he treated as express malice. In respect of unlawful, intentional acts, Hawkins treated them as murder, stating:

if a man happen to kill another in the execution of a malicious and deliberate purpose to do him a personal hurt, by wounding or beating him, or in the wilful commission of any unlawful act, which necessarily tends to raise tumults and quarrels, and consequently cannot but be attended with the danger of personal hurt to some one or other, as by committing a riot, robbing a park etc he shall be adjudged guilty of murder.

And a fortiori, he shall come under the same construction, who in the pursuance of a deliberate intention to commit a felony, chances to kill a man, as by shooting at tame fowl, with an intent to steal them etc for such persons are by no means favoured; and they must at their peril take care of the consequence of their actions; and it is a general rule, that where ever a man intending to commit one felony, happens to commit another, he is as much guilty as if he had intended the felony which he actually commits. ${ }^{776}$ (italics supplied)

Hawkins treated intentional, random, acts as murder, which seems apposite since there was no provocation. He stated:

Neither shall he be adjudged guilty of a less crime who kills another, in doing such a wilful act as shows him to be as dangerous as a wild beast, and an enemy of mankind in general, as by going deliberately with a horse used to strike, or discharging a gun, among a multitude of people, or throwing a great stone or piece of timber from a house onto the street, through which he knows many are passing; and it is no exercise that he intended no harm to any one in particular, or that he meant only to do it for sport, or to frighten people etc. ${ }^{777}$ (italics supplied)

\section{(b) Murder - Malice}

Although Hawkins did not discuss this case in detail, the meaning of 'malice' was discussed in Mawgridge (1707) ${ }^{778}$ by Holt CJ.

- After a brief review of the law of murder ${ }^{779}$ - and that it covered all homicides 'done by malice prepensed. ${ }^{780}$ Holt CJ sought to define 'malice' by distinguishing the latin terms for 'envy', 'hatred' and 'malice'; 781

- However, there is no evidence that Roman law made such a distinction. Further, no English legal writer prior to Holt CJ appears to have done so.

As to the meaning of 'malice', Holt CJ, quoting Erasmus, stated:

Malice is a design formed of doing mischief to another; cum quis data opera male agit, ${ }^{782}$ he that designs and uses the means to do ill is malicious. ${ }^{783}$...he that does a cruel act voluntarily, does it of malice prepensed. ${ }^{784}$

The latin citation and the reference to 'design' confuse the fact that Holt CJ was saying little beyond the fact that murder required premeditation ('design', 'voluntarily') - something long accepted. Also, that an intentional cruel act was a malicious

\footnotetext{
${ }^{774}$ Ibid. 'if persons take upon them to put others to death, either by virtue of a new commission wholly unknown to our laws, or by virtue of any known jurisdiction, which clearly extends not to cases of this nature, as if the court of Common Pleas cause a man to be executed for treason or felony, or the court martial, in time of peace, put a man to death by the martial law, both the judges and officers are guilty of murder.' For the latter see also Coke, at 28(a) (king's peace).

775 Ibid, p 87 noted the prevailing opinion that where a quack doctor or surgeon (one not 'duly authorised') occasioned the death of a patient, it was felony. However, Hawkins added 'But surely the charitable endeavours of those gentlemen who study to qualify themselves to give advice of this kind, in order to assist their poor neighbours, can by no means deserve so severe a construction from their happening to fall into some mistakes in their prescriptions, for which the most learned and experienced can not always be secure.'

${ }^{776}$ Hawkins cited Kel 117 who doubted Coke's suggestion that accidental, unlawful, killing was murder. They noted that Coke's marginal references did not support such a contention, but cf. Reading in 1520, see 20(b).

777 Ibid, p 74.

7781 Kel 119. See App B(c).

${ }^{779}$ Holt CJ thought that the word 'murder' was 'framed' (derived) from the murder fine of Canute, see 1 Kel, p 121. However, he provided no other analysis of Anglo-Saxon law. Cf. ns 88 \& 89 .

${ }^{780} 1 \mathrm{Kel}$ at $\mathrm{p} 124$. He stated 'It appears that of [from] Bracton the notion of murder is much altered, and comprehends all homicides, whether privately or publicly committed, if done by malice prepense'. One would assert this is incorrect. In Anglo-Saxon times it covered all homicides committed with premeditation (malice prepense) which were, per se, treated as 'secret' and opposed to 'open' (as in a brawl). This reflected the Old Testament position.

${ }^{781}$ Holt CJ defined 'envy' as 'a repining or being grieved at the happiness and prosperity of another' [he quoted Horace, Epistles, i, ii, 57 'invidus alterius rebus macrescit opimis' (the envious man grows lean at the prosperity of another)] and he defined 'hatred' [following Cicero in his Tusculan Disputions (Tuscualanae Disputationes), bk 4] as 'ira inveterata', a rancor fixed and settled in the mind of one towards another, which admits of several degrees, and may carry a man so far as to risk the hurt of him, though not to perpetrate it himself.' However, there is no evidence Roman law made such a clear distinction. Further, the Old Testament (the likely source of premeditated malice), also did not distinguish hatred, malice or enmity is any strict legal sense. See also Stephen, n 55, vol 3, p 70.

${ }^{782}$ D Erasmus, Annotationes in Novum Testamentum (1535), pt 3 (Annotations on the Epistle to the Romans, ch 1, v 30 ), p 80 'Hoc loco maluissem vertere 'maliciam' quae apud Senecam simpliciter usurpatur pro vitio; alioqui perversitatem sonat, cum quis data opera male agit.' Stephen, $\mathrm{n} 55$. vol 3 , p 70 does not note the source of Holt's quotation. It may be noted that Seneca, in his writings, used the 'malificia' as the opposite of 'virtus.'

${ }^{783} 1 \mathrm{Kel}$, at $\mathrm{p} 127$. Holt CJ referred to Coke, $\mathrm{n} 44$, vol 2, p 42. As Stephen, n 55, p 70 pointed out this is a mis-reference and that Holt CJ likely intended to refer to Coke, n 44, vol 3, p 62.

${ }^{784}$ Holt CJ cited Coke, $\mathrm{n} 44$, vol 3, p 62 'That is, voluntary and of set purpose, though it be done upon a sudden occasion: for if it be voluntary, the law implies malice.'
} 
one, since it evinced an intention to do ill (mischief). ${ }^{785}$ Thus, the definition of Holt CJ simply preserved the word 'malice', when it was superfluous.

\section{(c) Manslaughter}

Hawkins stated:

Homicide against the life of another, amounting to felony, is either with or without malice. That which is without malice is called manslaughter, or sometimes chance medley, by which we understand such killing as happens either on a sudden quarrel, or in the commission of an unlawful act, without any deliberate intention of doing any mischief at all. ${ }^{786}$

Hawkins then (perhaps rather unhelpfully) referred to his prior analysis of the law in his extract on murder, as well as observations made in his analysis of justifiable and excusable homicide. From these, it is apparent that Hawkins considered manslaughter to comprise homicide which did not otherwise fall into the categories of murder, accidental, justifiable or excusable homicide. Further, as will be seen in his discussion of accidental killing, it seems clear that, he treated negligent killing - whether lawful or unlawful - as manslaughter (the same as Hale).

\section{(d) Justifiable Homicide}

Hawkins noted that no pardon was required for justifiable homicide. ${ }^{787}$ For him, it covered killing:

- $\quad$ pursuant to due legal process; ${ }^{788}$

- $\quad$ a felon (one indicted or who had committed felony) resisting arrest; ${ }^{789}$

- $\quad$ escaping from prison; ${ }^{790}$

- $\quad$ rioters $;^{791}$

- highway robbery (brigandage) ${ }^{792}$

- housebreaking. ${ }^{793}$

Also, where the following statutes applied:

- $\quad$ Act of 1293 (on warrens, see 17);

- Act of 1532 (attempting to murder, rob or burgle, see 20(d));

- Act of 1553 (on unlawful assemblies, see 22). ${ }^{794}$

However, Hawkins then confused matters by placing as examples of justifiable homicide, cases that had formerly been examples of excusable homicide since he referred to killing by:

- $\quad$ a women resisting rape (self defence) ${ }^{795}$

- a servant defending his master (defence of another). ${ }^{796}$

Hawkins also regarded it as justifiable to kill a person attempting to murder. ${ }^{797}$ In all these cases, Hawkins emphasised that there must be necessity. ${ }^{798}$

\footnotetext{
${ }^{785}$ Holt cited Holloway (1628), see App B(g).

786 Ibid, p 76.

${ }^{787}$ Ibid, p 70 'where a special fact, amounting to justifiable homicide, is found by the jury, the party is to be dismissed, without being obliged to purchase any pardon etc.'

${ }^{788}$ Ibid. Hawkins noted that it did not cover an outlaw or a person attainted of treason or felony.

789 Hawkins, n 46, vol 1, p 70 'If a person having actually committed a felony will not suffer himself to be arrested, but stand on his own defence, or fly so that he cannot possibly be apprehended alive by those who pursue him, whether private persons or public officers, with or without a warrant from a magistrate, he may be lawfully slain by them.' Also, 'If an innocent person be indicted of a felony, where, in truth, no felony was committed, and he will not suffer himself to be arrested by the officer who has a warrant to that purpose, he may lawfully be killed by him, if he cannot otherwise be taken, for there is a charged against him upon the record to which at his peril he is bound to answer.'

${ }^{790}$ Ibid 'If a criminal endeavouring to break the gaol, assault his gaoler, he may be lawfully killed by him in the affray.' (italics supplied)

${ }^{791}$ Ibid, p 71 'If those who are engaged in a riot, or forcible entry, or detainer, stand in their defence and continue the force in opposition to the command of a justice of the peace etc or resist such justice endeavouring to arrest them, the killing of them may be justified; and so perhaps may the killing of dangerous rioters by any private persons, who cannot otherwise suppress them, or defend themselves from them, inasmuch as every private person seems to be authorized by the law to arm himself for the purposes aforesaid.'

${ }^{792}$ Ibid, 'where a man kills one who assaults him in the highway to rob or murder him'. See also the Act of 1532, see 20(d). Highway robbers were still a pestilence in the late $17^{\text {th }}$ to $18^{\text {th }}$ century and various Acts were directed against them. See Holdsworth, n 65, pp 405-6.

793 Ibid.

${ }^{794}$ Ibid. 'the owner of a house, or any of his servants, or lodgers etc kill one who attempts to burn it, or to commit in it murder, robbery or other felony.'

795 Ibid, p 71 'a woman kills one who attempts to ravish her.'

796 Ibid, 'a servant coming suddenly and finding his master robbed and slain, falls upon the murderer immediately and kills him; for he does it in the height of surprise, and under just apprehensions of the like attempt upon himself.' See also a case in 1352, see n 451.

${ }^{797}$ Ibid, p 72 'I can see no reason why a person, who without provocation, is assaulted by another in any place whatsoever, in such a manner as plainly shows an intent to murder him, as by discharging a pistol, or pushing at him with a drawn sword etc may not justify killing such an assailant, as much as if he had attempted to rob him.' See also Act of 1532 (attempting to murder in certain instances). See also the Marquis de Guiscard. A French refugee, in 1710, he stabbed Robert Harley (a statesmen) at a at a privy council meeting (he was being examined on a charge of high treason). The Marquis was wounded in the attempt and died a week later. Parliament treated his killing as a lawful and necessary action. See Amos, n 45, p 111 and Russell, n 51, vol $1, \mathrm{p} 794$ citing 9 Ann c 16 (1710).

798 Ibid. 'Neither shall a man in any case justify the killing another by a pretence of necessity, unless he were himself wholly without fault in bringing
} that necessity upon himself...' Also, p 69 'It must be owing to some unavoidable necessity, to which the person who kills another must be reduced 
In conclusion, the analysis of Hawkins is muddled. Although he cited various (long established) examples of justifiable killing, he also included in the same various examples of excusable killing.

\section{(e) Accidental Killing}

Hawkins noted that excusable homicide was either (a) by accident (per infortunium); or (b) in self defence (se defendendo). ${ }^{799}$ This was an unfortunate confusion between the two (taking the position back to before Bracton's own categorisation many centuries earlier, see 13). As to killing by accident, Hawkins cited the following examples:

- a labourer at work; ${ }^{800}$

- a horse running over a child; ${ }^{801}$

- a workman throwing material; ${ }^{802}$

- a schoolmaster correcting a child; ${ }^{803}$

- playing sports; $;^{804}$

- martial exercise such as a tournament; ${ }^{805}$

- dangerous, or unauthorised, sports. ${ }^{806}$

In these instances, it seems clear that, where the act was negligent (rash), and whether lawful or not, this was manslaughter and not accidental killing.

\section{(f) Excusable Killing}

As noted in (d), Hawkins treated as justifiable homicide, matters usually treated as examples of excusable homicide. In respect of self defence, Hawkins emphasised the 'back to the wall' principle:

I am to consider homicide se defendendo, which seems to be where one who has no other possible means of preserving his life from one who combats with him on a sudden quarrel, or of defending his person from one who attempts to beat him (especially if such attempt be made upon him in his own house) kills the person by whom he is reduced to such an inevitable necessity. ${ }^{807}$

Hawkins noted that this was not required in the case of a police officer or in the case of brigandage. ${ }^{808}$

In conclusion, Hawkins' rather jumbled analysis did not add anything to Hale (or Blackstone). Further, his categorisation of justifiable and excusable killing (to also include accidental killing) was confusing.

\section{Blackstone (1765-9) $)^{809}$}

Blackstone - in book four of his Commentaries on the Laws of England (1769) - considered homicide. ${ }^{810}$ He stated:

without any manner of fault in himself. There must be no malice coloured under pretence of necessity, for wherever a person who kills another, acts in truth upon malice, and takes occasion from the appearance of necessity to execute his own private revenge, he is guilty of murder...'.

799 Ibid, p 73 'Excusable homicide is either per infortunium, or se defendendo.'

${ }^{800}$ Ibid.'Where a labourer being at work with a hatchet, the head thereof flies off, and kills one who stands by.' This is taken from the Book of Deuteronomy, see 7(a)(ii).

${ }^{801}$ Ibid 'Where a third person whips a horse on which a man is riding, whereupon he springs out, and runs over a child and kills him, in which case the rider is guilty of homicide per infortunium; and he who gave the blow, of manslaughter.'

${ }^{802}$ Ibid. 'Where a workman, having first given loud warning to all persons to stand clear, flings down a piece of timber from a private house standing out of the road, and thereby kills one who happens to be underneath (but if any person fling down such a piece of timber idly in play, or even a workman fling it down in the streets of a town, where the danger is apparent in respect of the number of people continually passing by, he is guilty of manslaughter).'

${ }^{803}$ Ibid. pp 73-4 'Where a schoolmaster in correcting his scholar, or a father his son, or a master his servant, or an officer in whipping a criminal condemned to such punishment, happens to occasion his death (yet if such persons in their correction, be so barbarous as to exceed all bounds of moderation, and thereby cause the party's death, they are guilty of manslaughter at the least, and if they make use of an instrument improper for correction, and apparently endangering the party's life, as an iron bar, or sword etc or kick him to the ground, and then stamp on his belly and kill him, they are guilty of murder).'

${ }^{804}$ Ibid, p 74 'Where one lawfully using an innocent diversion, as shooting at butts, or at a bird etc by the glancing of an arrow, or such like accident, kills another.' Also 'Where a person happens to kill another in playing a match of football, wrestling, or such like sports which are attended with no apparent danger to life, and intended only for the trial, exercise, and improvement, of the strength, courage, and activity of the parties.'

${ }^{805}$ Ibid, p 74 'Where one kills another in fighting at barriers or tilting by the king's command, which by the better opinion, secures him from being guilty of felony, by reason of any such unfortunate accident.'

${ }^{806}$ Ibid 'But if a person kill another by shooting at a deer etc in a third person's park, in the doing whereof he is a trespasser; or by shooting off a gun, or throwing stones in a city or highway, or other place where men usually resort; or by throwing stones at another wantonly in play, which is a dangerous sport, and has not the least appearance of any good intent; or by doing any other such idle action as cannot but endanger the bodily hurt of some one or other; or by tilting or playing at hand sword without the king's command, or by parrying with naked swords covered with buttons at the points, or with swords in the scabbards, or such like rash sports, which cannot be used without the manifest hazard of life, he is guilty of manslaughter.' (italics supplied)

${ }^{807}$ Ibid, pp 74-5. He continued: 'And not only he who on an assault retreats to a wall, or some such straight, beyond which he can go no further, before he kills the other, is adjudged by the law to act upon unavoidable necessity: but also he who being assaulted in such a manner, and in such a place, that he cannot go back without manifestly endangering his life, kills the other without retreating at all. And notwithstanding a person who retreats from an assault to the wall, gave the other divers wounds in the retreat, yet if he give him no mortal one till he get thither, and then kills him, he is guilty of homicide se defendendo only.'

${ }^{808}$ Ibid, p 75 'An officer who kills him that resists in the execution of his office, and even a private person that kills one who feloniously assaults him on the highway, may justify the fact without ever giving back at all.'

${ }^{809}$ Other writers at the time of Blackstone such as H Finch, A Description of the Common Laws of England (1759) $\mathrm{p} 63$ and T Wood, An Institute of the Laws of England (last ed, 1772), added little. For example, Finch, p 63 'Murder, which is of malice prepense.' 
Now homicide, or the killing of any human creature, is of three kinds; justifiable, excusable and felonious. The first has no share of guilt at all; the second very little; but the third is the highest crime against the law of nature, that man is capable of committing. ${ }^{811}$

\section{(a) Murder}

Blackstone referred to the crime of:

deliberate and wilful murder; a crime at which human nature starts... ${ }^{812}$ (italics supplied)

After indicating that 'murder' originally referred to the murder fine ${ }^{813}$ (abolished in 1340) ${ }^{814}$ Blackstone followed Coke's definition ${ }^{815}$ and - after considering the meaning of 'sound memory and discretion',816 - he analysed the other pre-requisites:

- $\quad$ Unlawfully Kills. Blackstone stated: 'when a person of such sound discretion unlawfully kills. The unlawfulness arises from the killing without warrant or excuse: and there must also be an actual killing to constitute murder; for a bare assault, with intent to kill, [i.e. attempted murder] 'is only a great misdemeanour, though formerly it was held to be murder' ${ }^{817}$ Blackstone also noted that murder could occur through neglect; ${ }^{818}$

- King's Peace. Blackstone stated: 'the person killed must be 'a reasonable creature in being, and under the king's peace', at the time of the killing. Therefore to kill an alien, a jew, or an outlaw, who are all under the king's peace or protection, is as much murder as to kill the most regular born Englishman; except he be an alien enemy, in time of war.'; 819

- Malice Aforethought. Blackstone stated: 'the killing must be committed with malice aforethought, to make it the crime of murder. This is the grand criterion, which now distinguishes murder from other killing: and this malice prepense, malitia praecogitata, is not so properly spite or malevolence to the deceased in particular, as any evil design in general; the dictate of a wicked, depraved, and malignant heart; un disposition a faire un male chose ${ }^{820}$ and it may be either express, or implied in law.' ${ }^{821}$

Blackstone then considered express ${ }^{822}$ and implied malice. ${ }^{823}$ In the case of express malice this included killing (a) in a duel; ${ }^{824}$ (b) with cruelty; ${ }^{825}$ (c) at random. ${ }^{826}$ As to provocation, Blackstone stated:

\footnotetext{
${ }^{810}$ Blackstone, $\mathrm{n} 48$, vol 4, $\mathrm{p} 177$ 'The subject... of the present chapter will be, the offence of homicide or destroying the life of man, in its several stages of guilt, arising from the particular circumstances of mitigation or aggravation which attend it.'

${ }^{811}$ Ibid, pp 177-8.

${ }^{812}$ Ibid, p 194.

${ }^{813}$ Ibid. 'The name of murder was anciently applied only to the secret killing of another (which the word, moerda, signifies in the Teutonic language) and it was defined 'homicidium quod nullo vidente, nullo sciente, clam perpetratur' [citing Glanvill, see 11], for which the vill wherein it was committed, or (if that was too poor) the whole hundred, was liable to a heavy amercement; which amercement itself was also denominated murdrum. This was the ancient usage among the Goths in Sweden and Denmark; who supposed the neighbourhood, unless they produced the murderer, to have perpetrated or at least connived at the murder: and, according to Bracton, was introduced into this kingdom by king Canute, to prevent his countrymen the Danes from being privily murdered by the English; and was afterwards continued by William the Conqueror, for the like security to his own Normans. And therefore if, upon inquisition had, it appeared that the person found slain was an Englishman (the presentment whereof was denominated englescherie) the country seems to have been excused from this burden.'

${ }^{814}$ Ibid. 'But this difference being totally abolished by statute 14 Edw III c 4 [1340] we must now (as is observed by Staundforde, see 23) define murder in quite another manner, without regarding whether the party slain was killed openly or secretly, or whether he was of English or foreign extraction.'

${ }^{815}$ Ibid, p 195. 'Murder is therefore thus now defined, or rather described, by sir Edward Coke [see 28], 'when a person, of sound memory and discretion, unlawfully kills any reasonable creature in being and under the king's peace, with malice aforethought, either express or implied.' The best way of examining the nature of this crime will be by considering the several branches of this definition.'

${ }^{816}$ Ibid, p 196 'First, it must be committed by a person of sound memory and discretion: for a lunatic or infant...are incapable of committing any crime; unless in such cases where they show a consciousness of doing wrong, and of course a discretion, or discernment, between good and evil.'

${ }^{817}$ Blackstone cited Hale, see 30. Blackstone also indicated, n 48, vol 4, p 196, that perjury was treated as murder but that it was 'hardly so at his day.' See also Eden, n 48, pp 239-41.

818 Ibid, p 197. Blackstone cited a case in 1328, see n 432.

${ }^{819}$ Blackstone, p 198 cited Coke and Hale, see 28 \& 30. There is no suggestion that Blackstone sought to exclude monstrous or badly deformed children.

${ }^{820}$ Blackstone referred to a dictum of Ley CJ in Blount (1624), see App B(c).

${ }^{821}$ Blackstone, n 48, vol 4, p 199.

${ }^{822}$ Ibid 'one, with a sedate deliberate mind and formed design, does kill another: which formed design is evidenced by external circumstances discovering that inward intention; as lying in wait, antecedent menaces, former grudges, and concerted schemes to do him some bodily harm.' Blackstone cited Hale, see 30.

${ }^{823}$ Ibid. 'in many cases where no malice is expressed, the law will imply it: as, where a man wilfully poisons another, in such a deliberate act the law presumes malice, though no particular enmity can be proved. And if a man kills another suddenly, without any, or without a considerable, provocation, the law implies malice; for no person, unless of an abandoned heart, would be guilty of such an act, upon a slight or no apparent cause.' Blackstone cited Hale, see 30.

${ }^{824} \mathrm{Ibid}, \mathrm{p} \mathrm{199.} \mathrm{'This} \mathrm{takes} \mathrm{in} \mathrm{the} \mathrm{case} \mathrm{of} \mathrm{deliberate} \mathrm{duelling,} \mathrm{where} \mathrm{both} \mathrm{parties} \mathrm{meet} \mathrm{avowedly} \mathrm{with} \mathrm{an} \mathrm{intent} \mathrm{to} \mathrm{murder:} \mathrm{thinking} \mathrm{it} \mathrm{their} \mathrm{duty,} \mathrm{as}$ gentlemen, and claiming it as their right, to wanton with their lives and those of their fellow creatures; without any warrant or authority from any power either divine or human, but in direct contradiction to the laws both of God and man: and therefore the law has justly fixed the crime and punishment of murder, on them, and on their seconds also.' Blackstone cited Hawkins, see 31. It may be noted that duelling was still prevalent at this time. JM Beattie, Crime and the Courts in England 1660-1800 (1986), p 98 'Duels were certainly still common in the late seventeenth century and were not unusual in the eighteenth.' See also D Andrew, The Code of Honour and its Critics: The Opposition to Duelling in England 1700-1850 (1980) Social History 5, pp 412-3. It may also be noted that juries were often reluctant to convict. See also Eden, n 48, ch 19. For general texts on duelling of interest, see R Hopton, Pistols at Dawn. A History of Duelling (2007) and R Robert, The Duel. A History (1965).
} 
No affront, by words, or gestures only, is a sufficient provocation, so as to excuse or extenuate such acts of violence as manifestly endanger the life of another. ${ }^{827}$

Blackstone then cited examples of:

- $\quad$ excessive chastisement; ${ }^{828}$

- $\quad$ killing an officer in the execution of his duty; ${ }^{829}$

- $\quad$ killing when intending to commit another felony. ${ }^{830}$

Finally, Blackstone noted (as had Coke and Hale) that: 'all homicide is presumed to be malicious, until the contrary appears upon evidence. 831

Thus, Blackstone cited 5 cases of implied malice: (a) unprovoked killing; (b) killing a police officer in the execution of his duty; (c) killing arising from a felony (cf. Coke and Hale who had referred to an unlawful act); (d) transferred malice; (e) killing by poison. Blackstone treated killing by cruelty (which would seem to include duress by a gaoler)as express malice. He does not appear to have dealt with killing by a thief (robber).

\section{(b) Manslaughter}

Blackstone stated:

Manslaughter is therefore thus defined, ${ }^{832}$ the unlawful killing of another, without malice either express or implied: which may be either voluntary [intentionally], upon a sudden heat; or involuntarily, but in the commission of some unlawful act. ${ }^{833}$

Thus, manslaughter had become more clearly defined to cover killing: (a) by way of extenuation from murder, after provocation ('upon a sudden heat'); or (b) in the course of some unlawful act. The effect was that the concept of 'chance medley' began to fade away, to be replaced by analysing whether a person had killed subsequent to provocation or in self defence. ${ }^{834}$ As to provocation, Blackstone (effectively) indicated that the quarrel had to be sudden and the response immediate.

Sudden Quarrel. Blackstone stated: 'if upon a sudden quarrel two persons fight, and one of them kills the other, this is manslaughter: and so it is, if they upon such an occasion go out and fight in a field; for this is one continued act of passion: and the law pays that regard to human frailty, as not to put a hasty and a deliberate act upon the same footing with regard to guilt. So also if a man be greatly provoked, as by pulling his nose, or other great indignity, and immediately kills the aggressor, though this is not excusable se defendendo, since there is no absolute necessity for doing it to preserve himself; yet neither is it murder, for there is no previous malice; but it is manslaughter';

Time to Cool. Blackstone stated: 'But in this, and in every other case of homicide upon provocation, if there be a sufficient cooling time for passion to subside and reason to interpose, and the person so provoked afterwards kills the other, this is deliberate revenge and not heat of blood, and accordingly amounts to murder...Manslaughter therefore on a sudden provocation differs from excusable homicide se defendendo in this: that in one case there is an apparent necessity, for self-preservation, to kill the aggressor; in the other no necessity at all, being only a

\footnotetext{
825 Ibid, 'if even upon a sudden provocation one beats another in a cruel and unusual manner, so that he dies, though he did not intend his death, yet he is guilty of murder by express malice, that is, by an express evil design, the genuine sense of malitia.' Blackstone referred to Holloway (1628), see App B(g) and Hale, see $\mathbf{3 0 .}$

${ }^{826}$ Ibid, p 200. 'Neither shall he be guilty of a less crime, who kills another in consequence of such a wilful act, as shows him to be an enemy to all mankind in general; as going deliberately with a horse used to strike, or discharging a gun, among a multitude of people. So if a man resolves to kill the next man he meets, and does kill him, it is murder, although he knew him not; for this is universal malice [random killing].' Blackstone cited Hale, see 30 .

827 Ibid, p 200. Blackstone referred to Hawkins and Hale, see $\mathbf{3 1} \& \mathbf{3 0}$.

${ }^{828}$ Ibid. 'But if the person so provoked had unfortunately killed the other, by beating him in such a manner as showed only an intent to chastise and not to kill him, the law so far considers the provocation of contumelious behaviour, as to adjudge it only manslaughter, and not murder.'

${ }^{829}$ Ibid, pp 200-1. 'In like manner if one kills an officer of justice, either civil or criminal, in the execution of his duty, or any of his assistants endeavouring to conserve the peace, or any private person endeavouring to suppress an affray or apprehend a felon, knowing his authority or the intention with which he interposes, the law will imply malice, and the killer shall be guilty of murder.' Blackstone cited Hale and Foster, see $\mathbf{3 0} \& \mathbf{3 4}$.

${ }^{830}$ Ibid. 'And if one intends to do another felony, and undesignedly kills a man, this is also murder. Blackstone then cited a case of transferred malice 'Thus, if one shoots at A and misses him, but kills B, this is murder; because of the previous felonious intent, which the law transfers from the one to the other....'

831 Ibid, p 201. 'It were endless to go through all the cases of homicide, which have been adjudged either expressly, or impliedly, malicious: these therefore may suffice as a specimen; and we may take it for a general rule, that all homicide is malicious, and of course amounts to murder, unless where justified by the command or permission of the law; excused on a principle of accident or self-preservation; or alleviated into manslaughter, by being either the involuntary consequence of some act, not strictly lawful, or (if voluntary) occasioned by some sudden and sufficiently violent provocation. And all these circumstances of justification, excuse, or alleviation, it is incumbent upon the prisoner to make out, to the satisfaction of the court and jury: the latter of whom are to decide whether the circumstances alleged be proved to have actually existed; the former, how far they extend to take away or mitigate the guilt. For all homicide is presumed to be malicious, until the contrary appears upon evidence.'

${ }^{832}$ Blackstone cited Hale, see 28.

833 Ibid, pp 191.

${ }^{834}$ Baker, n 84, p 530 'the doctrine of chance medley faded away and the test of manslaughter in such cases came to be, not the hot bloodedness, but the presence of absence or absence of a sufficient degree of 'provocation'. Baker cites cases such as Royley (1612), Keite (1696) and Mawgridge (1707), see App B(c), however, it may be noted that Hawkins (in 1716) was still referring to chance medley, see 31, as did subsequent writers.
} 
sudden act of revenge. ${ }^{835}$

For example, to kill another in the act of adultery with his wife was manslaughter, given the provocation. ${ }^{836}$ In respect of unlawful acts, Blackstone gave the following examples:

No Intent. Blackstone stated:

'if two persons play at sword and buckler, unless by the king's command, and one of them kills the other: this is manslaughter, because the original act was unlawful; but it is not murder, for the one had no intent to do the other any personal mischief. ${ }^{, 837}$

Also, 'in general, when an involuntary killing happens in consequence of an unlawful act, it will be either murder or manslaughter according to the nature of the act which occasioned it. If it be in prosecution of a felonious intent, it will be murder; but if no more was intended than a mere trespass, it will only amount to manslaughter.' 838 (underlining supplied)

Negligence. Blackstone stated:

'where a person does an act, lawful in itself, but in an unlawful manner, and without due caution and circumspection: as where a workman flings down a stone or piece of timber into the street, and kills a man; this may be either misadventure, manslaughter or murder, according to the circumstances under which the original act was done:

if it were in a country village, where few passengers are, and he calls out to all persons to have a care, it is misadventure only: but if it were in London, or other populous town, where people are continually passing, it is manslaughter, though he gives loud warning, ${ }^{839}$ and murder, if he knows of their passing and gives no warning at all, for then it is malice against all mankind. ${ }^{840}$ (underlining supplied)

This category remained unsatisfactory since, where the act was unlawful or not, should have been separated from whether the mens rea exhibited in the case of the actual killing was. Further, to describe an act 'lawful in itself, but in an unlawful manner' was to make negligent, ipso facto, unlawful. What does seem clear is that Blackstone restricted murder to unlawful, intentional, acts - and, probably, felonious ones at that (following Foster, the first edition of whose work was in 1762). Thus, for Blackstone, manslaughter comprised:

- unlawful, negligent, acts;

- unlawful, accidental, acts;

- $\quad$ lawful, negligent, acts.

\section{(c) Accidental Killing}

Blackstone treated accidental killing under the category of excusable homicide:

Excusable homicide is of two sorts; either per infortunium, by misadventure; or se defendendo, upon a principle of self-preservation... Homicide per infortunium, or misadventure, is where a man, doing a lawful act, without any intention of hurt, unfortunately kills another: ${ }^{841}$

Blackstone considered examples in respect of; (a) tournaments; ${ }^{842}$ and (b) whipping a horse. ${ }^{843}$ Blackstone also noted that -

\footnotetext{
835 Ibid, p 191-2.

${ }^{836}$ Blackstone continued, pp 191-2 'So, if a man takes another in the act of adultery and kills him directly upon the spot...in England it is not absolutely ranked in the class of justifiable homicide, as in the case of forcible rape but it is manslaughter...'. Blackstone cited Hale, see $\mathbf{3 0 .}$

${ }^{837}$ Blackstone cited Coke, see 28.

${ }^{838}$ Ibid, p 193. It may be noted that, by Blackstone's time, there was public disquiet at the severity of the unlawful rule. See e.g. G Sharp, Remarks on the Opinions of some of the most celebrated writers on the Crown law respecting the due distinction between Manslaughter and Murder (1773). See also Eden (1771), n 48, ch 19.

${ }^{839}$ Blackstone cited Hull (1664).

${ }^{840}$ Blackstone Coke, see 28.

${ }^{841}$ Ibid, pp 182-3. Blackstone gave examples: (a) 'man is at work with a hatchet, and the head thereof flies off and kills a stander by'; (b) 'a person, qualified to keep a gun, is shooting at a mark, and undesignedly kills a man: for the act is lawful, and the effect is merely accidental'; (c) a parent is moderately correcting his child, a master his servant or scholar, or an officer punishing a criminal'. Cf. where it exceeded the bounds of moderation.

${ }^{842} \mathrm{Ibid}, \mathrm{p} 183$ 'A tilt or tournament, the martial diversion of our ancestors, was however an unlawful act; and so are boxing and swordplaying, the succeeding amusement of their posterity: and therefore if a knight in the former case, or a gladiator in the latter, be killed, such killing is felony of manslaughter. But, if the king command or permit such diversion, it is said to be only misadventure; for then the act is lawful...' Blackstone cited Hale and Hawkins, see 30 \& 31. Blackstone noted: 'by the laws both of Athens and Rome, he who killed another in the pancratium, or public games, authorized or permitted by the State, was held not to be guilty of homicide. See also Digest, n 182, bk 9.1.7.4 quoting Ulpian's Edict, bk 4 'If a man kills another in the colluctatio or in the pancratium or in a boxing match (provided the one kills the other in a public bout), the Lex Aquila does not apply because the damage is seen to have been done in the cause of glory and valor and not for the sake of inflicting unlawful harm...Clearly [though] if someone wounds a contestant who has thrown in the towel the Lex Aqulia will apply.' (italics supplied)

843 Ibid. 'Likewise to whip another's horse, whereby he runs over a child and kills him, is held to be accidental in the rider, for he has done nothing unlawful; but manslaughter in the person who whipped him, for the act was a trespass, and at best a piece of idleness [negligence], of dangerous consequence. And in general, if death ensues in consequence of any idle, dangerous, and unlawful sport, as shooting or casting stones in a town, or the barbarous division of cock-throwing, in these and similar cases, the slayer is guilty of manslaughter, and not misadventure only, for these are unlawful acts.' Blackstone cited Hawkins, Hale and Foster, see 30-32. As to what cock throwing comprised see Amos, n 45 , p 143.
} 
by his time - no pardon and writ of restitution of goods was required. Instead, the party would be acquitted. ${ }^{844}$

\section{(d) Justifiable Killing}

Blackstone distinguished between justifiable and excusable homicide. In the former, no crime was committed. ${ }^{845}$ As to the latter, Blackstone stated:

Justifiable homicide is of divers kinds. Such as is owing to some involuntary necessity, without any will, intention, or desire, and without any inadvertence or negligence, in the party killing, and therefore without any shadow of blame. ${ }^{846}$

Blackstone gave the following examples:

- $\quad$ pursuant to due legal process; ${ }^{847}$

- $\quad$ an officer in execution of his office (in a civil or criminal case) killing one who assaulted and resisted him; ${ }^{848}$

- $\quad$ an officer (or private person) killing a man charged with felony who resisted him; ${ }^{849}$

- a prisoner in prison (or going to prison) assaulting the jailer (or officer) who, in defence, killed him; ${ }^{850}$

- $\quad$ attempted rape or buggery. ${ }^{851}$

Blackstone also referred to the following Acts, noting the overlap:

- Act of 1293 (on warrens, see 17); ${ }^{852}$

- Act of 1532 (attempting to murder, rob or burgle, see 20(d)); ${ }^{853}$

- Act of 1714. In a riot (or rebellious assembly), officers endeavouring to disperse the mob were justified in killing. ${ }^{854}$

Blackstone indicated such homicide was only justifiable when absolutely necessary. ${ }^{855}$

\section{(e) Excusable Killing}

Blackstone indicated that homicide was excusable when:

- $\quad$ in self-defence, ${ }^{856}$

\footnotetext{
${ }^{844}$ Ibid, p 188 'to prevent this expense [of getting a pardon] in cases where the death has notoriously happened by misadventure or in self-defence, the judges will usually permit (if not direct) a general verdict of acquittal.'

${ }^{845} \mathrm{Ibid}, \mathrm{p} 182$ 'In these instances of justifiable homicide, you will observe that the slayer is in no kind of fault whatsoever, not even in the minutest degree; and is therefore to be totally acquitted and discharged, with commendation rather than blame. But that is not quite the case in excusable homicide, the very name whereof imports some fault, some error, or omission; so trivial however, that the excuses it from the guilt of felony, though it strictness it judges it deserving of some little degree of punishment.' (italics supplied)

${ }^{846}$ Ibid, p 178

${ }^{847}$ Ibid. 'As, for instance, by virtue of such an office as obliges one, in the execution of public justice, to put a malefactor to death, who has forfeited his life by the laws and verdict of his country. This is an act of necessity, and even of civil duty; and therefore not only justifiable, but commendable, where the law requires it. But the law must require it, otherwise it is not justifiable: therefore wantonly to kill the greatest of malefactors, a felon or a traitor, attainted or outlawed, deliberately, uncompelled, and extrajudicially, is murder.' Blackstone cited Bracton, see $\mathbf{1 2}$ and Hale, see 28. Blackstone also made it clear that killing by way of private revenge was murder. Ibid, p 179 'If another person does it [kills another] of his own head, it is held to be murder.' Blackstone cited Hale, see 30.

${ }^{848}$ Blackstone cited Hale, see $\mathbf{2 8}$ and Hawkins, see 29

${ }^{849}$ Blackstone, $\mathrm{n} 48$, vol 4, p 179. Cf. This did not apply in the case of a claim for debt. One could justify beating one trespassing on one's good but not killing him, unless a felon.

${ }^{850}$ Ibid.

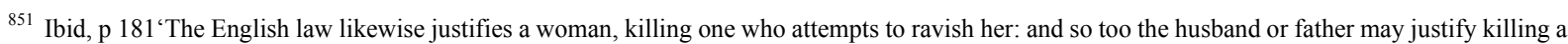
man, who attempts a rape upon his wife or daughter; but not if he takes them by adultery by consent, for the one is forcible and felonious, but not the other And I make no doubt but the forcibly attempting a crime, of a still more detestable nature, may be equally resisted by the death of the unnatural aggressor...For the one uniform principle that runs through our own, and all other laws, seems to be this: that where a crime, in itself capital, is endeavoured to be committed by force, it is lawful to repel that force by the death of the party attempting.' See also Eden, n 48, p 211.

${ }^{852}$ Ibid. See also 3 \& 4 W \& M c 10 (1691, deer stealing, rep 1776).

${ }^{853}$ Ibid, p 180 'If any person attempts a robbery or murder of another, or attempts to break open a house in the night time (which also extends to an attempt to burn it) and shall be killed in such attempt, the slayer shall be acquitted and discharged. This reaches not to any crime unaccompanied with force, as picking of pockets, or to the breaking open of any house in the day time, unless it carries with it an attempt of robbery also.' See also Act of 1532 , see 20(d). It may be noted that, in 1722, an Act ( 9 Geo I c 22 s 1) made it a felony to 'wilfully and maliciously shoot at any person in any dwelling house or other place.' See also Holdsworth, n 65, vol 11, p 536.

${ }^{854}$ Ibid, p 180. The Act, s 3, provided that 'if the persons so unlawfully, riotously and tumultuously assembled...shall happen to be killed, maimed or hurt, in the dispersing, seizing or apprehending...by reason of their resisting the persons so dispersing etc...every [JP], sheriff etc....and all and singular persons, being aiding and assisting to them....shall be free, discharged and indemnified...' See also 1 Eliz c 16 (1558)(rep 1863)(which extended the Act of 1553, see 20(d)) and the Riot Act 1714 (1 Geo 1 c 5)(re 1973). The latter effectively replaced the Act of 1553 on Unlawful Assemblies, although the Act of 1553 was not formally abolished until 1863 , see $\mathrm{n} 481$.

${ }^{855} \mathrm{Ibid}, \mathrm{p} 180$. 'But, in all these cases, there must be an apparent necessity on the officer's side; viz. that the party could not be arrested or apprehended, the riot could not be suppressed, the prisoners could not be kept in hold, the deer stealers could not but escape, unless such homicide was committed; otherwise, without such absolute necessity, it is not justifiable.'

${ }^{856}$ Ibid, p 184 'Homicide in self-defence, or se defendendo, upon a sudden affray, is also excusable rather than justifiable, by the English law. This species of self-defence must be distinguished from that just now mentioned, as calculated to hinder the perpetrator of a capital crime; which is not only a matter of excuse, but of justification.'
} 
- $\quad$ in defence of certain others (including one's master). ${ }^{857}$

Excusable homicide only could be a plea if: 'the slayer had no other possible means of escaping from his assailant. ${ }^{858}$ Therefore, the killer must have retreated as far as he could. ${ }^{859}$ Further, it should not be effected by way of revenge or pretended self defence. ${ }^{860}$ Blackstone indicated the connection between: (i) chance medley in the context of provocation in a brawl; and (ii) chance medley in self- defence:

self-defence... is that whereby a man may protect himself from an assault, or the like, in the course of a sudden brawl or quarrel, by killing him who assaults him. And this is what the law expresses by the word chance medley, or (as some rather choose to write it) chaud medley; the former of which in its etymology signifies a casual affray, the latter an affray in the heat of blood or passion: both of them of pretty much the same import; but the former is in common speech too often erroneously applied to any manner of homicide by misadventure [i.e. accident]; whereas it appears by the statute 24 Hen VIII c 5 [i.e. Act of 1532, see 20] and our ancient books, ${ }_{862}{ }^{861}$ that it is properly applied to such killing as happens in self defence upon a sudden encounter... ${ }^{862}$

In some cases this species of homicide (upon chance medley in self defence) differs but little from manslaughter, which also happens frequently upon chance-medley in the proper legal sense of the word. But the true criterion between them seems to be this: when both parties are actually combating at the time when the mortal stroke is given, the slayer is then guilty of manslaughter; but if the slayer has not begun to fight, or (having begun) endeavours to decline any further struggle, and afterwards, being closely pressed by his antagonist kills him to avoid his own destruction, this is homicide excusable by self-defence. ${ }^{86}$

Blackstone's observations show that the law had not developed distinct principles of killing after provocation and killing as a result of self-defence. ${ }^{864}$

- However, what was of considerable use was the approach of Blackstone that (in effect) the brawl or the term 'chance medley' were not relevant for legal purposes. What was, was to consider whether there had been provocation (if so, then manslaughter and not murder). Also, if the killing had been in self- defence (in which case, it was akin to accident);

- Thus, Blackstone moved away from attempts to formulate (endless) propositions of law on what should have always been simple issues of fact for a jury.

As with accidental homicide, Blackstone noted that, in the case of killing in self-defence, a pardon was not required and acquittal was sufficient. ${ }^{865}$

In conclusion, Blackstone wrote more simply and elegantly than Hale (albeit Hale's History was posthumous and the author would, likely, have corrected it) and Hawkins. Further, instead of simply listing out examples of killing in 'hot blood' or where the act was unlawful, Blackstone set down the basic principles. In the case of homicide, Blackstone moved away from the issue of the brawl as such and concentrated on what were, in any case, its basic components: provocation (which, if sufficient, would reduce the crime of killing to manslaughter) and self defence.

\section{Summary: Law to 1769}

The criminal law - in respect of murder and manslaughter, as well as defences to the same - changed little in the period from when Coke wrote to when Blackstone wrote. Further, Coke and Hale were the major authorities which other writers such as Hawkins and Blackstone followed. As it was, by 1769, the law on homicide had simplified a little. Thus, the position was as follows:

- Murder. As in 1641, by 1769, if the killing was premeditated, it was murder. The crime remained unclergyable and there was forfeiture (of land and goods). A pardon was also unlikely. For the purposes of determining

\footnotetext{
${ }^{857}$ Ibid, p185 'Under this excuse of self defence, the principal civil and natural relations are comprehended; therefore master and servant, parent and child, husband and wife, killing an assailant in the necessary defence of each other, respectively, are excused; the act of the relation assisting being construed the same as the act of the party himself.' Blackstone cited Hale, see 28.

${ }^{858}$ Ibid, p 184.'This right of natural defence does not imply a right of attacking: for, instead of attacking one another for injuries past or impending, men need only have recourse to the proper tribunals of justice. They cannot therefore legally exercise this right of preventative defence, but in sudden and violent cases; when certain and immediate suffering would be the consequence of waiting for the assistance of the law. Wherefore, to excuse homicide by the plea of self-defence, it must appear that the slayer had no other possible means of escaping from his assailant.'

${ }^{859}$ Ibid, pp 185. 'The party assaulted must therefore flee as far as he conveniently can, either by reason of some wall, ditch or other impediment; or as far as the fierceness of the assault will permit him: for it may be so fierce as not to allow him to yield a step, without manifest danger of his life, or enormous bodily harm; and then in his defence he may kill his assailant instantly.' Blackstone cited Hale, see 28.

${ }^{860}$ Ibid, p 185 'And, as the manner of the defence, so is also the time to be considered: for if the person assaulted does not fall upon the aggressor until the affray is over, or when he is running away, this is revenge and not defence. Neither, under the colour of self defence, will the law permit a man to screen himself from the guilt of deliberate murder; for if two persons, A \& B, agree to fight a duel, and A gives the first onset, and B retreats as far as he safely can, and then kills A, this is murder; because of the previous malice and concerted design. But if A upon a sudden quarrel assaults B first, and upon B's returning the assault, A really and bona fide flees; and, being driven to the wall, turns again upon B and kills him; this may be se defendendo according to some of our writers: though others have thought this opinion too favourable; in as much as the necessity, to which he is at last reduced, originally arose from his own fault.' Blackstone cited Hale, see $\mathbf{2 8}$ and Hawkins.

${ }^{861}$ Blackstone cited Staunford, see $\mathbf{2 3}$.

${ }^{862}$ Blackstone cited Coke and Foster, see 28 \& 34.

863 Ibid, p 184.

${ }^{864}$ One would agree with Beattie, n 824, p 91 'The distinction between excusable homicide and manslaughter was perhaps becoming less clear in the eighteenth century'.

${ }^{865}$ See n 844.
} 
premeditation, malice was still categorised into: (a) express; and (b) implied. However, there was disparity of what was in the respective categories. In the time when Coke was published (1641) there were 7 categories where malice had to be implied because there was no actual malice or grudge or plotting against the victim, viz:

(a) unprovoked killing;

(b) killing a police officer in the execution of his duty;

(c) killing arising from an unlawful act;

(d) killing by a thief (robber); ${ }^{866}$

(e) killing by transferred malice;

(f) killing by neglect/cruelty (to the extent not express malice); ${ }^{867}$

(g) poison.

Hale followed Coke's 7 categories. Blackstone followed Coke and Hale but treated (f) as express malice and in the case of (d), he does not seem to have dealt with it. Blackstone (and Hawkins) also referred to 'random' killing which is, really, an aspect of (a).

As to unlawful acts leading to killing, a Reading of 1520 had included accidental acts as murder (as did Coke). Lambard referred to Herbert (1588) which dealt with an intentional unlawful act, but he did not refer to accidental acts as such. Coke supported accidental unlawful acts leading to death being murder. However, Hale limited murder to intentional unlawful acts and it seems that Blackstone (like Foster) further limited murder to intentional felonious unlawful acts.

- Manslaughter. Manslaughter was the same in 1759 as in 1641. It was a felony but, up to 1827, benefit of clergy was available and there was a greater chance of securing a pardon. By Blackstone, the concept of 'chance medley' was beginning to fade away, since brawling was dividing out into the issues of: (a) provocation; (b) self defence. Manslaughter (by the time Blackstone wrote): also comprised: (i) killing pursuant to unlawful acts which were intentional (but not felonious) or negligent or accidental; (ii) killing pursuant to negligent, but lawful, acts.

- $\quad$ Accidental Killing. By Blackstone's time, a pardon was not required and a person could be acquitted by the court. This was a welcome advance.

- Justifiable Killing. In 1641, it was justifiable (at common law) to kill: (a) pursuant to due legal process; (b) a felon who resisted capture; (c) a burglar (night thief); ${ }^{868}$ (d) a housebreaker; (e) an enemy in war time; (f) an escaping prisoner; (g) a thief assaulting a person; (h) in a licensed martial game (though this would be treated as an accident). Further, Acts of Parliament also made it justifiable to kill where the following applied: (i) Act of 1293 (warrens etc); (b) Act of 1532 (attempting to murder, rob or burgle); (c) Act of 1553 (unlawful assemblies); (d) Riot Act 1714.

By 1769, (a), (b), (e) and (f) still applied. As to (c), (d) and (g), these had become (in legal writing) merged into (b) (felony). Also, as in 1641, the Act of 1532 (attempting to rob, murder, burgle at night) superceded the common law position, to an extent. And, as in 1641, (h) was obsolete since games licensed by the Crown (such as tournaments and jousts) had become obsolete, as had any system of licensing. The Act of 1293 still applied. The Act of 1553 (in effect) had been superceded by the Riot Act 1714;

- Excusable. In Bracton's time, it was a defence to kill a person: (a) in self defence; (b) to defend one's family (and servants); (c) to defend one's master (lord). This still applied in 1769. However, by Blackstone's time, a pardon was not required and a person could be acquitted by the court. This was a welcome advance.

\section{Foster (1776)}

The first edition of Foster's text on Crown Law was published in 1762. However, the second edition, corrected, was published in 1776 and it is the one I cite. ${ }^{869}$ Foster made some useful observations in his discourse on homicide and some cases he referred to were often cited thereafter.

\section{(a) Murder}

Foster, like Holt CJ in Mawgridge (1707), thought the word 'murder' derived from the murder fine but made no effort to trace the history of the matter before Bracton. ${ }^{870}$ He held murder to have the pre-requisite of malice prepense ${ }^{871}$ and noted that the law 'presumes the fact [the killing] to have been founded in malice, until the contrary appears.' ${ }^{872}$ As to malice aforethought, Foster stated:

the law by the term malice...means, that the fact has been attended with such circumstances as are ordinary symptoms of a wicked, depraved, malignant spirit...The words per malitiam and malitiose our oldest writers do indeed frequently use in some other cases, and they constantly mean an action flowing from a wicked and corrupt motive, a thing done malo animo, mala conscientia, as they express themselves...The malus animus...brings the

\footnotetext{
${ }^{866}$ The implied malice really flows from the Act of 1532 (see 20(d)). Given that it was justifiable to kill a thief seeking to rob one (see Act of 1532 ), it is fairly obvious that thieves, knowing this, would, more likely, kill the victim when the latter sought to resist.

${ }^{867}$ I say 'to the extent not express malice' since there seems to have been an active ingredient of 'plotting' (intention) in the 1328 and 1599 cases and also, doubtless, where a jailer starved his prisoner or placed him in manifestly insalubrious conditions.

${ }^{868}$ Cf. Fitzherbert, n 471, p 75 (in 1651) 'Burglary shall not be judged, but where there is breaking of a house by night.'

${ }^{869}$ Foster, a judge of the king's bench, died in 1763 . He often cited Hale for whom he had a great respect. For comments on Foster on homicide, see Stephen, n 55, vol 3, pp 74-7.

${ }^{870}$ Foster, n 77, p 302. Cf. ns 81 \& 82.

871 Ibid, p 307.

${ }^{872}$ Ibid, p 255. Foster referred to Oneby (1727), see App B(a)
} 
offence within the denomination of wilful malicious murder...

And I believe most, if not all the cases, which in our books are ranged under the head of implied malice, will, if carefully adverted to, be found to turn upon this single point, that the fact has been attended with such circumstances as carry in them the plain indications of a heart regardless of social duty and fatally bent upon mischief. ${ }^{873}$

The problem of defining 'malice' as a heart 'fatally bent upon mischief', is that it was so nebulous. Further, as a circumlocution for 'evil intention', the first was (as in Old Testament) a moral judgment, not a legal principle.

\section{(b) Manslaughter - Chance Medley}

As to manslaughter Foster stated:

The cases falling under the denomination of manslaughter, where death ensues from actions in themselves unlawful, but not proceeding from a felonious intention, or from actions in themselves lawful, but done without due care and circumspection for preventing mischief [i.e. negligence]...the cases falling under the head of manslaughter, which most frequently occur, are those where death ensues upon a sudden affray and in heat of blood, upon some provocation given or conceived. ${ }^{874}$ (underlining supplied)

Thus, Foster limited murder to felonious unlawful acts. As to the distinction between premeditated malice and where the killing was done in hot blood (chance medley) ${ }^{875}$ Foster stated:

In the former the malitia, the wicked vindictive disposition already mentioned, evidently appears. In the latter it is as evidently wanting. The party in the first transport of his passion intended to chastise for a piece of insolence, which few spirits can bear. In this case the benignity of the law interposes in favour of human frailty, in the other it's justice regards and punishes the apparent malignity of the heart..

And it ought to be remembered, that in all other cases of homicide upon slight provocation, if it may be reasonably collected from the weapon made use of, or from any other circumstance, that the party intended to kill, or to do some great bodily harm, such homicide will be murder. The mischief done is irreparable, and the outrage is considered as flowing rather from brutal rage or diabolical malignity than from human frailty, and it is to human frailty, and to that alone, the law indulges in every case of felonious homicide. ${ }^{876}$

\section{(c) Unlawful Acts}

Foster stated:

if the act be unlawful, I mean if it be malum in se, the case will amount to felony, either murder or manslaughter, as the circumstances may vary the nature of it. If it be done in prosecution of a felonious intention it will be murder, but if the intent went no further than to commit a bare trespass, manslaughter....

A shoots at the poultry of $\mathrm{B}$, and by accident kills a man; if his intention was to steal the poultry, which must be collected from the circumstances, it will be murder by reason of that felonious intent, but if it was done wantonly and without that intention it will be barely manslaughter.

The rule I have laid down supposes, that the act from which the death ensued was malum in se. For if it was barely malum prohibitum, as shooting at game by a person not qualified by statute law to keep or use a gun for that purpose, the case of a person so offending will fall under the same rule as that of a qualified man, for the statutes prohibiting the destruction of the game, under certain penalties, will not, in a question of that kind, enhance the accident beyond its intrinsic moment. ${ }^{877}$ (wording divided for ease of reference and underlining supplied)

As Stephen noted, Foster's analysis of unlawful acts was some improvement on Coke's since Foster limited murder to unlawful felonious acts. However, it was still objectionable ${ }^{878}$ since it converted acts into murder when there was no intent to kill.

In conclusion, Foster, being a judge of a conservative frame of mind was stating the law as it was. Therefore, he did not deal with what reforms would be useful. As a Commission in 1834 was later to note (see 37), his definition of 'malice aforethought' - although correctly reflecting the law of his time - was vague and uncertain. Further, Foster made no reflection on whether provocation should be a question of fact rather than of law. Nor as to the inadequacy of the legal position re unlawful acts.

\section{East (1803)}

The only edition of East, A Treatise of the Pleas of the Crown, was issued in 1803. It was superceded by Russell's work in

\footnotetext{
${ }^{873}$ Foster, n 77, pp 256-7.

${ }^{874}$ Ibid, p 290. As to duelling, Foster stated the long prevailing law, p 297 'deliberate duelling, if death ensues, is in the eye of the law murder, for duels are generally founded in deep revenge, and though a person should be drawn into a duel, not upon a motive so criminal, but merely upon the punctillo of what the swordsmen falsely call honour, that will not excuse, for he that deliberately seeks the blood of another upon a private quarrel acts in defiance of all laws human and divine, whatever his motive may be.'

${ }^{875}$ Foster, n 77, p 275 noted that 'The term chance-medley has been very improperly applied to the case of accidental death...But the ancient legal notion of homicide by chance-medley was when death ensued from a combat between the parties upon a sudden quarrel.' Also, Ibid, p 276 'a sudden casual affray commenced and carried on in the heat of blood.' The reason why chance medley was being 'improperly' applied was due to the fact that the courts were not separating it into its component parts of (a) provocation; and (b) self defence.

${ }^{876}$ Ibid, p 291

${ }^{877}$ Ibid, p 289.

${ }^{878}$ Stephen, n 55, p 77. Stephen described such a legal stance as 'cruel and monstrous.' However, he accepted that it was an advance on Coke 'It certainly is less objectionable to say that unintentional homicide committed in the prosecution of a felonious design is murder, than to say that unintentional homicide committed by any unlawful act is murder.'
} 
1819 and, therefore, it is not discussed in detail. ${ }^{879}$ However, East's work was often later cited because of the long list of cases he presented (especially on provocation). Also, East was the first legal writer to treat homicide in real depth after Hale, dedicating over 130 pages to it. ${ }^{80}$ The following comments may be made:

\section{(a) Categorisation}

Bracton had categorised homicide into: (a) intentional; (b) accidental; (c) justifiable; (d) excusable (see 13). East categorised them into: (a) murder; (b) manslaughter; (c) accidental; and (d) excusable, which latter 'relates either to the execution or advancement of justice, or self defence.' 881

- The problem of this was to confuse justifiable killing (where there was no crime) with excusable killing (where there was a crime but also an adequate defence). Other writers from Pulton had done the same; ${ }^{882}$

- $\quad$ East noted (following Foster) that chance medley was being treated as an aspect of accidental killing (self defence), when it had long been treated as an aspect of manslaughter. ${ }^{883}$

The result was confusion. As East noted:

the shades between some of these are in many instances very faint, and...the difficulty in this branch of law lies chiefly in discriminating between the one and the other... ${ }^{884}$

\section{(b) Murder}

East defined murder as follows:

Murder, in the sense in which it is now understood, is the voluntary [intentional] killing any person...under the king's peace, of malice prepense or aforethought either express or implied by law: ${ }^{885}$ the sense of which word malice is not only confined to a particular ill-will to the deceased, but is intended to denote, as [Foster] expresses it, an action flowing from a wicked and corrupt motive, a thing done malo animo, where the facts has been attended with such circumstances as carry in them the plain indications of an heart regardless of social duty and fatally bent upon mischief. And therefore malice is implied from any deliberate cruel act against another, however sudden. ${ }^{886}$

Likely because the law as to premediated malice was so opaque by this time, East categorised murder as including:

The grosser instances of murder, where the depravity of the heart or malice...is apparent, form the $1^{\text {st }}$ class of cases under this head. ${ }^{887} 2$ Where an officer, or one who assists in the advancement of justice where he lawfully may, is killed in the regular discharge of his duty. 3 Where a private man, lawfully interfering to prevent a breach of the peace, is opposed in such his endeavour, and slain. 4 Where death happens incidentally in the prosecution of some other felony. 5 Where it happens from other unlawful acts, of which death was the probable consequence, done deliberately, and with the intention of mischief or great bodily harm to particulars, or of mischief indiscriminately fall where it may; though the death ensue against or beside the original intent of the party. 6 . From deliberate duelling. ${ }^{888}$

This also was not conducive to clarity and it comprised East's own categorisation.

\section{(c) Manslaughter}

East stated:

Manslaughter, which is principally distinguishable from murder in this, that, though the act which occasions the

\footnotetext{
${ }^{879}$ Another forgotten work is a monograph, Beville, $\mathrm{n}$ 47. It is useful since it lists out many of the cases on homicide in his time. Beville equated malice with intent, p 18 'Malice is used to describe the intent with which the offence is committed; and as it cannot be murder, unless there be an intent to kill or to hurt the person of another, and unless this intent be both felonious and deliberate, I think it is evident that malice means, a felonious and deliberate intent to kill or to hurt the person of another...' (italics supplied)

${ }^{880}$ As well as another 50 pages to the legal procedure.

${ }^{881}$ East, $\mathrm{n} 50$, vol 1, p 214. East also treated suicide as a separate category.

${ }^{882}$ See also Beville, n 47, p 2 'I have not adopted the usual division between excusable and justifiable homicide, because homicide, which was formerly considered as merely excusable, is now in effect put upon the same footing as if it were justifiable.'

${ }^{883}$ Ibid, 'per infortunium or chance-medley'. Ibid, p 221 'The ancient legal notion of homicide by chance-medley was, when death ensued from a combat between the parties upon a sudden quarrel; but it has since been frequently confounded with misadventure or accident.' Cf. Beville, $\mathrm{n} 47$, $\mathrm{p} 86$ 'Homicide per infortunium is sometimes called chance-medley, but in its proper signification chance-medley appears to mean the sudden killing of any person in an affray...' Burn, n 47, $\left(23^{\text {rd }}\right.$ ed, 1820), vol 2, p 785 'I have purposely avoided the word chancemedly in this place, because authors do not seem to be agreed whether it is to be applied to homicide by misadventure, or to manslaughter. Ld Coke and Mr Hawkins seem to understand it of manslaughter; Lord Hale and others, of homicide by misadventure. The original meaning of the word seems to favour the former opinion, as it signifies a sudden or casual meddling or contention; whereas homicide by misadventure supposes no previous meddling or falling out. But the same author sometimes in different places applies it to both of them promiscuously.'

${ }^{884}$ Ibid. East thought his categorization improved things, 'a different arrangement seems necessary in order to facilitate inquiry and avoid repetition a much as possible.'

${ }^{885}$ Ibid, p 224 'Lying in wait, antecedent menaces, former grudges, and concerted schemes to do a person some bodily harm, are some of the many circumstances which are evidence of a particular malice.' Also, 'the more deliberate and depraved species of that offence, where the mind has brooded upon its prey, and marked out the object of destruction in cool blood. [i.e. duelling] And therefore suffice it to say upon this head, that in all cases where it appears that there was an interval of reflection, or a reasonable time for the blood if it had been heated to cool, after which the deadly purpose is effected; however grievous the provocation may have been, the party killing is guilty of murder...'

${ }^{886}$ Ibid, pp 214-5.

${ }^{887}$ Ibid, p 223 'The grosser instances of wilful murder, where the malignity of the heart is apparent, need no explanation: the circumstances of every such case are peculiar to itself.'

${ }^{888}$ Ibid, p 215.
} 
death be unlawful, or likely to be attended with bodily mischief, yet the malice either express or implied, which is the very essence of murder, is presumed to be wanting in manslaughter; and the act being imputed to the infirmity of human nature, the correction ordained for it is proportionally lenient. ${ }^{889}$

This treated manslaughter as a residual category, covering all homicide that was not murder or accidental killing or falling within the categories of justifiable or excusable killing. ${ }^{890}$ In respect of unlawful acts East referred to intentional and negligent acts, although not defining them as such. He stated:

if a person, breaking in an unruly horse, wilfully ride him among a crowd of persons, the possible danger being great and apparent, and death ensue from the viciousness of the animal, it is murder. For how can it be supposed that a person wilfully doing an act, so manifestly attended with danger, especially if he showed any consciousness of such danger himself, should intend any other than the probable consequence of such an act.

But yet if it appear clearly to have been done heedlessly and incautiously only, [i.e. negligently] and not with an intent to do mischief, it is only manslaughter: though Hawkins considers that it would be murder if the person intended to divert himself with the fright of the crowd.

So if a man, knowing that people are passing along the street, throw a stone likely to create danger, or shoot over the house or wall, with intent to do hurt to people, and one is thereby slain; it is murder, on account of the previous malice, though not directed against any particular individual: for it is no excuse that the party was bent upon mischief generally.

But if the act was done incautiously [i.e. negligently], without any such intent, which must be collected from the circumstances, it is only manslaughter. ${ }^{891}$

East's illustrations of what, today, would be treated as reckless killing was taken from Hawkins (see 31(b)).

\section{(d) Justifiable \& Excusable Killing}

As noted in (a), East conflated justifiable homicide ${ }^{892}$ with excusable homicide ${ }^{893}$ with the result that, for example, homicide arising from execution due to due legal process was treated as excusable. ${ }^{894}$

\section{(e) Accidental Killing}

East noted that accidental killing did not include where the act was unlawful. Thus:

The act upon which the death ensues must be lawful in itself; for if it be malum in se, the case will amount to felony, either murder or manslaughter, according to the circumstances. If it be merely malum prohibitum, as shooting at game by an unqualified person, that will not vary the degree of the offence. The usual examples under this head are, $1^{\text {st }}$, where death ensues from innocent recreations; 2ndly from moderate and lawful correction in foro domestico; 3rdly, from acts lawful or indifferent in themselves done with proper and ordinary caution. ${ }^{895}$

In conclusion, East provided some useful cases but, otherwise, added little and his text was superceded by that of Russell, which proved to be long lasting.

Note: This is the end of Part 1 of this Article. Part 2 will consider the law on murder and manslaughter up to modern times.

\section{Copyright}

Copyright for this article is retained by the author(s), with first publication rights granted to the journal.

This is an open-access article distributed under the terms and conditions of the Creative Commons Attribution license (http://creativecommons.org/licenses/by/3.0/).

\footnotetext{
${ }^{889}$ Ibid, p 218. 'The offence amounts to felony, but with the benefit of clergy; and the offender shall be burned in the hand, and forfeit all his goods and chattels. By stat 19 Geo 3 c 74 [1779], ss 3 \& 4 the burning in the hand may in the discretion of the court be changed to a moderate fine; and but not to whipping: but this does not prevent the court from also adjudging the offender to be imprisoned for any term not exceeding a year.'

${ }^{890}$ East, $\mathrm{n} 50$, vol 1, p 219 'The cases falling under the head of manslaughter are either, $1^{\text {st }}$, where death ensues from actions in themselves unlawful, but not proceeding from a malicious or felonious intention; 2ndly, from actions in themselves lawful, but done without due care and circumspection for preventing mischief' 3rdly, where death ensues upon a sudden combat or affray; or, 4thly, from the heat of blood upon a reasonable provocation given.' See also Beville, n 47, p 54 'Every instance in which it is possible for one man to kill another, which is felonious, and which does not amount to murder, is manslaughter.'

${ }^{891}$ Ibid, pp 232-3. See also p 256 et seq.

${ }^{892}$ Ibid, p 219 'To make homicide justifiable, it must arise from an imperious duty, prescribed by the law, or be owing to some avoidable necessity induced by the act of the party killed, without any manner of fault in the party killing.'

${ }^{893} \mathrm{Ibid}, \mathrm{p} 220$ 'Homicide is only excusable where the party killing is not altogether free from blame, but the necessity, which renders it excusable, may be said to be partly induced by his own act.'

${ }^{894}$ Ibid.

${ }^{895}$ Ibid, p 222
} 